\title{
Hydrogeologic Characterization of the U-3at Collapse Zone
}

\author{
Prepared by \\ Bechtel Nevada \\ Geotechnical Sciences \\ Las Vegas, Nevada \\ Prepared for \\ U.S. Department of Energy \\ National Nuclear Security Administration \\ Nevada Site Office \\ Las Vegas, Nevada
}

August 2005 


\title{
DISCLAIMER STATEMENT
}

Reference herein to any specific commercial product, process, or service by trade name, trademark, manufacturer, or otherwise, does not necessarily constitute or imply its endorsement, recommendation, or favoring by the U.S. Government or any agency thereof or its contractors or subcontractors.

\section{AVAILABILITY STATEMENT}

Available for sale to the public from-

\author{
U.S. Department of Commerce \\ National Technical Information Service \\ 5285 Port Royal Road \\ Springfield, VA, 22161-0002 \\ Telephone: 800.553.6847 \\ Fax: 703.605.6900 \\ E-mail: orders@ntis.gov \\ Online ordering: http://www.ntis.gov/ordering.htm
}

Available electronically at http://www.osti.gov/bridge.

Available for a processing fee to U.S. Department of Energy and its contractors, in paper, from-

U.S. Department of Energy

Office of Scientific and Technical Information

P.O. Box 62

Oak Ridge, TN 37831-0062

Telephone: 865.576.8401

Fax: 865.576.5728

E-mail: reports@adonis.osti.gov 


\title{
Hydrogeologic Characterization of the U-3at Collapse Zone
}

\author{
Prepared by \\ Bechtel Nevada \\ Geotechnical Sciences \\ Las Vegas, Nevada
}

Prepared for

U.S. Department of Energy

National Nuclear Security Administration

Nevada Site Office

Las Vegas, Nevada

August 2005 
This page intentionally left blank. 


\section{Hydrogeologic Characterization of the U-3at Collapse Zone}

\section{DOE/NV/11718--199-REV.1}

\section{Preface}

The Special Projects Section of Reynolds Electrical \& Engineering Co., Inc. (REECo) and REECo's successor, Bechtel Nevada (BN) (among other entities), were responsible for characterizing the subsurface hydrogeology of the Area 3 Radioactive Waste Management Site (RWMS) at the Nevada Test Site for the U.S. Department of Energy, Nevada Operations Office in the early to mid-1990s. This work was documented in a series of limited-distribution data reports. As part of BN's current scope for closure planning for the Area 3 RWMS, some of these older data reports are being updated and submitted for approval for public release so they will be accessible for public review and for citation in future documents.

A document titled "Hydrogeologic Characterization of the Unsaturated Zone at the Area 3 Radioactive Waste Management Site” was prepared by BN in February 1998 and assigned the document number DOE/NV/11718--210. This document included several reports that address various portions of the Area 3 RWMS, some of which were assigned separate document numbers. None of the included documents or the larger comprehensive document were approved for public release. To permit public access to these data and to relieve confusion caused by this arrangement of nested documents, four reports within the larger document are being updated and released separately.

This document was originally prepared by BN under the same title in February 1998, and is one of the four documents that were included in the larger report. This report has been updated by revising it to conform to current editorial standards of BN and the U.S. Department of Energy, National Nuclear Security Administration Nevada Site Office. 
This page intentionally left blank. 


\title{
Hydrogeologic Characterization of the U-3at Collapse Zone
}

\section{DOE/NV/11718--199-REV.1}

\begin{abstract}
Hydrogeologic characteristics and properties of the U-3at collapse zone were determined from cores obtained from two angled boreholes drilled in 1996 under the subsidence crater formed by an underground nuclear test in 1963. This crater, used for disposal of bulk low-level radioactive waste since 1988, is located within the Area 3 Radioactive Waste Management Site in Yucca Flat on the Nevada Test Site in Nye County, Nevada. The purpose of this characterization effort was to provide data required to develop a conceptual hydrogeologic model and to complete flow and transport modeling required for the Area 3 performance assessment and composite analysis.
\end{abstract}

To minimize disturbance of the core samples, drilling was done by a method that used only air as the drilling fluid. No evidence of preferential pathways for water flow was detected via visual geologic descriptions of the core samples. Laboratory analyses showed physical and hydraulic properties that are typical of alluvial valleys at the Nevada Test Site. Water content values ranged from 0.05 to 0.33 cubic meters per cubic meter, with water content tending to increase with depth. Water potential values ranged from -10.7 MegaPascals at a depth of 15.3 meters to greater than -0.40 MegaPascals at 78.9 meters. Tritium concentrations in pore water extracted from the cores were below the detection limits from the surface to a depth of 118.9 meters. Below this depth, concentrations generally increased to a maximum of 2,200 picoCuries per liter in the deepest sample at 146.9 meters.

Unusually wet alluvium recovered from the drill bit during drilling between 50.9 and 71.6 meters in the first borehole raised concerns that water condensed in the compressed air system or excess oil introduced into the borehole may have penetrated core segments intended for analyses. The drilling process was modified to preclude introduction of fluids and the borehole was completed without further evidence of excess water. Using the same drilling method, the second borehole adjacent to the first was drilled and sampled over the interval from 47.5 to 78.3 meters. Analyses of samples from the second borehole showed water content values, water potential values, and stable isotope concentrations consistent with those of samples from the first borehole. This demonstrated that fluids had not been introduced into core segments intended for analyses during drilling of the first borehole, and thus the elevated water values are considered to be natural. 
This page intentionally left blank. 


\section{Table of Contents}

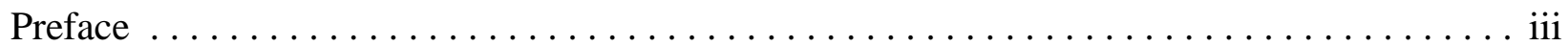

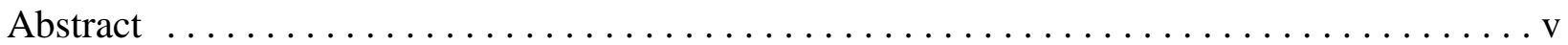

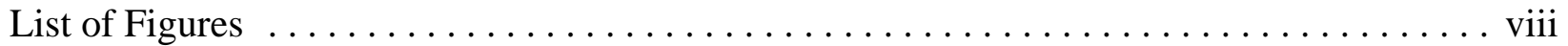

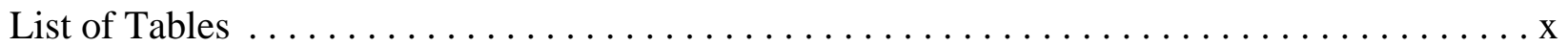

List of Acronyms and Abbreviations $\ldots \ldots \ldots \ldots \ldots \ldots \ldots \ldots \ldots \ldots \ldots \ldots \ldots \ldots \ldots \ldots$

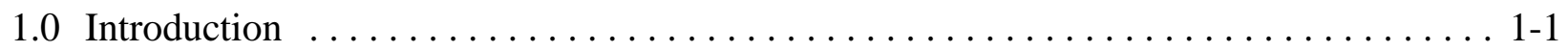

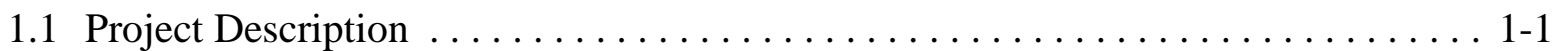

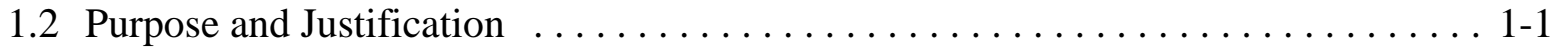

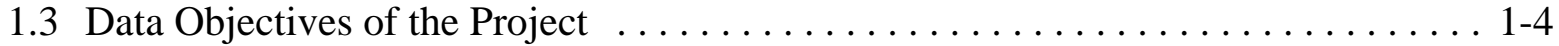

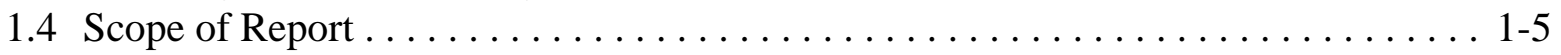

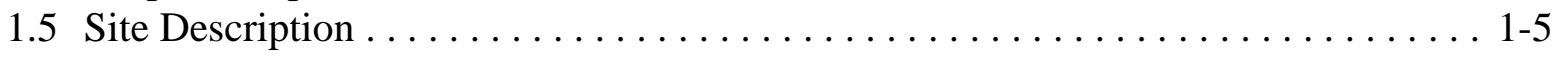

2.0 Test Review and Borehole Construction $\ldots \ldots \ldots \ldots \ldots \ldots \ldots \ldots \ldots \ldots$. . . . . . . . . . . . . . . . . . . . . . . .

2.1 Review of the U-3at Underground Nuclear Test $\ldots \ldots \ldots \ldots \ldots \ldots \ldots \ldots$. . . . . . . . . . . . . . .

2.1.1 General Information on Subsidence Craters $\ldots \ldots \ldots \ldots \ldots \ldots \ldots \ldots \ldots . \ldots \ldots$

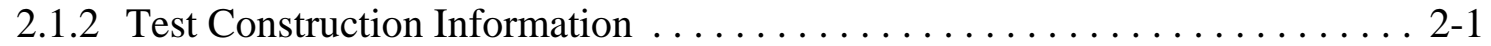

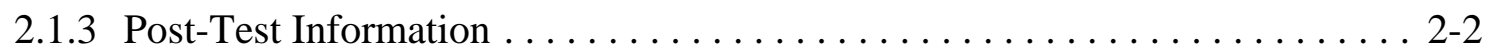

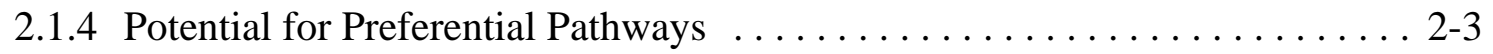

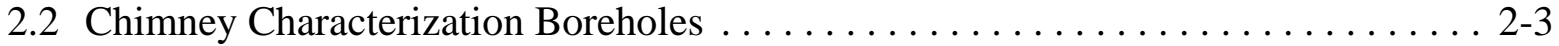

2.2.1 Drilling and Sampling Methods for Borehole U-3at-D1 . . . . . . . . 2-4

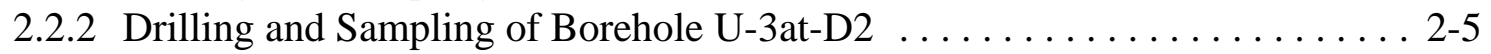

2.3 Laboratory Tests . . . . . . . . . . . . . . . . . . . . . . . 2-5

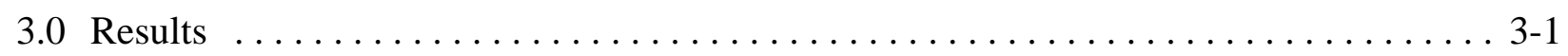

3.1 Geologic Properties of Borehole U-3at-D1 $\ldots \ldots \ldots \ldots \ldots \ldots \ldots \ldots \ldots \ldots$. . . . . .

3.2 Hydrogeologic Properties of Borehole U-3at-D1 . . . . . . . . . . . . . . . . 3-1

3.3 Environmental Tracers at Borehole U-3at-D1 . . . . . . . . . . . . . . 3-18

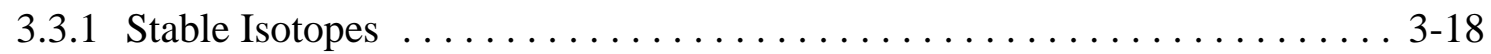

3.3.2 Chloride and Calcium Carbonate Profiles . . . . . . . . . . . . . . . . 3-18

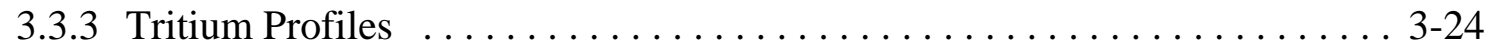

3.4 Results of Verification Testing at Borehole U-3at-D2 . . . . . . . . . . . . . 3-24

4.0 Summary $\ldots \ldots \ldots \ldots \ldots \ldots \ldots \ldots \ldots \ldots \ldots \ldots \ldots \ldots \ldots \ldots \ldots \ldots \ldots \ldots$

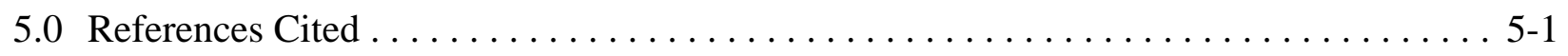

Distribution List

Appendix A Borehole Log Sheets for Exploratory Boreholes U-3at-D1 and U-3at-D2

Appendix B Characterization Data Tables 


\section{List of Figures}

Number

Title

Page

1-1 Location of the Area 3 Radioactive Waste Management Site

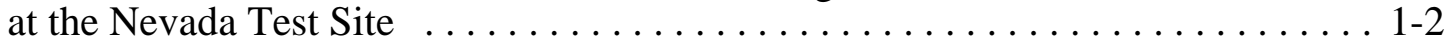

1-2 Map of Area 3 Radioactive Waste Management Site Showing Locations of Characterization Boreholes ........................... 1-3

1-3 Location of the Area 3 Radioactive Waste Management Site in Yucca Flat . . . . 1-7

2-1 Schematic Showing Locations of Boreholes U-3at-D1 and U-3at-D2 with Respect to the U-3at Crater and Estimated Margins of the Collapse Zone

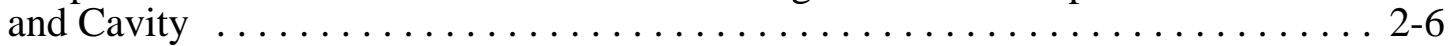

3-1 Particle Density versus Depth for U-3at-D1 $\ldots \ldots \ldots \ldots \ldots \ldots \ldots \ldots \ldots . \ldots . \ldots .2$

3-2 Sand, Silt and Clay Fractions versus Depth for U-3at-D1 . . . . . . . . . . 3-3

3-3 Dry Bulk Density versus Depth for U-3at-D1 . . . . . . . . . . . . . . . 3-4

3-4 Water Retention Relations for U-3at-D1 Samples from 8 Depths from 5.4 to 22.9 Meters . . . . . . . . . . . . . . . . . . . . .

3-5 Water Retention Relations for U-3at-D1 samples at 10 Depths from 25.4 to 49.3 Meters . . . . . . . . . . . . . . . . . . . . . . 3-6

3-6 Water Retention Relations for U-3at-D1 Samples at 10 Depths from 52.0 to 74.0 Meters . . . . . . . . . . . . . . . . . . . . . .

3-7 Water Retention Relations for U-3at-D1 Samples at 10 Depths from 76.3 to 97.9 Meters . . . . . . . . . . . . . . . . . . . . . 3-8

3-8 Water Retention Relations for U-3at-D1 Samples at 10 Depths from 100.1 to 124.2 Meters . . . . . . . . . . . . . . . . . . . . . . 3-9

3-9 Water Retention Relations for U-3at-D1 Samples at 10 Depths from 126.5 to 147.2 Meters . . . . . . . . . . . . . . . . . . . . . 3-10

3-10 Hydraulic Conductivity / Water Content Relations for U-3at-D1 Samples at 8 Depths from 5.4 to 22.9 Meters . . . . . . . . . . . . . . . 3-11

3-11 Hydraulic Conductivity / Water Content Relations for U-at-D1 Samples at 10Ten Depths from 25.4 to 49.3 Meters . . . . . . . . . . . . . . . . . 3-12

3-12 Hydraulic Conductivity / Water Content Relations for U-3at-D1 Samples at 10 Depths from 52.0 to 74.0 Meters . . . . . . . . . . . . . . . 3-13

3-13 Hydraulic Conductivity / Water Content Relations for U-3at-D1 Samples at 10 Depths from 76.3 to 97.9 Meters . . . . . . . . . . . . . . . 3-14

3-14 Hydraulic Conductivity / Water Content Relations for U-3at-D1 Samples at 10 Depths from 100.1 to 124.2 Meters . . . . . . . . . . . . . . . . . . . 3-15

3-15 Hydraulic Conductivity / Water Content Relations for U-3at-D1 Samples at 10 Depths from 126.5 to 147.2 Meters . . . . . . . . . . . . . . . 3-16

3-16 Volumetric Water Content versus Depth for U-3at-D1 . . . . . . . . . . . . . 3-17

3-17 Water Potential versus Depth for U-3at-D1 . . . . . . . . . . . . . . . 3-19

3-18 Deuterium Concentrations in Pore Water from U-3at-D1 versus Depth . . . . . . 3-20

3-19 Oxygen-18 Concentrations in Pore Water from U-3at-D1 versus Depth . . . . . . 3-21

3-20 Stable Isotope Concentrations in Pore Water from U-3at-D1 and Local Meteoric Water Line (LMWL) . . . . . . . . . . . . . . . . . . . 3-22 


\section{List of Figures (continued)}

Number

Title

Page

3-21 Soil Chloride Concentrations versus Depth for U-3at-D1 . . . . . . . . . . . . 3-23

3-22 Calcium Carbonate Equivalent within the Fine-Earth Fraction (less than

2 millimeters) versus Depth for U-3at-D1 . . . . . . . . . . . . . . . . 3-25

3-23 Tritium Concentrations versus Depth for U-3at-D1 $\ldots \ldots \ldots \ldots \ldots \ldots \ldots . . .26$

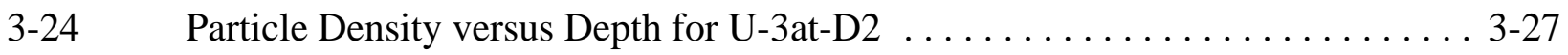

3-25 Sand, Silt, and Clay Fractions versus Depth for U-3at-D2 $\ldots \ldots \ldots \ldots \ldots \ldots$ 3-28

3-26 Dry Bulk Density versus Depth for U-3at-D2 . . . . . . . . . . . . . 3-29

3-27 Water Retention Relations for U-3at-D2 Samples at 14 Depths from 48.0 to

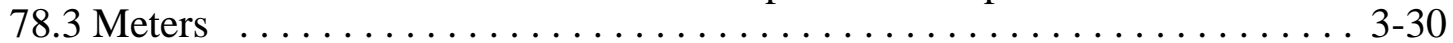

3-28 Hydraulic Conductivity / Water Content Relations for U-3at-D2 Samples at 14 Depths from 48.0 to 78.3 Meters $\ldots \ldots \ldots \ldots \ldots \ldots \ldots \ldots \ldots \ldots \ldots \ldots \ldots \ldots \ldots . .31$

3-29 Soil Chloride Concentration versus Depth for U-3at-D2 $\ldots \ldots \ldots \ldots \ldots \ldots$ 3-32

3-30 Calcium Carbonate Equivalent within the Fine-Earth Fraction (less than 2

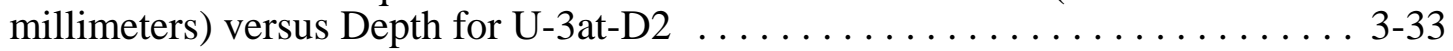

3-31 Tritium Concentration versus Depth for U-3at-D2 . . . . . . . . . . . . 3-34

3-32 Comparison of Volumetric Water Content from 40 to 80 Meters Depth in U-3at-D1and U-3at-D2 . . . . . . . . . . . . . . . . . . . . . . . . . . 3-35

3-33 Comparison of Water Potential for 40 to 80 Meters Depth in U-3at-D1 and U-3at-D2 .................................... 3-37

3-34 Comparison of Deuterium Concentrations in Pore Water from 46 to 78 Meters Depth in U-3at-D1 and U-3at-D2 . . . . . . . . . . . . . . 3-38

3-35 Comparison of Oxygen-18 Concentrations in Pore Water from 46 to 78 Meters Depth in U-3at-D1 and U-3at-D2 . . . . . . . . . . . . . . . . . . 3-39

3-36 Comparison of Stable Isotope Concentrations in Pore Water from U-3at-D2 and Local Meteoric Water Line . . 


\section{List of Tables}

Number

Title

Page

2-1 Location and Depth of Characterization Boreholes U-3at and U-3at-D2 . . . . . . . 2-4

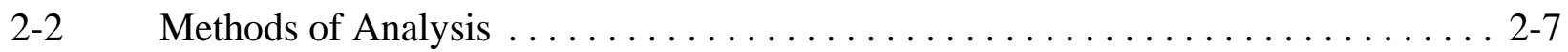

B-1 Particle Density for U-3at-D1 Characterization Samples . . . . . . . . . . . . B-1

B-2 Particle Size Distribution for the Fine- Earth ( $<2$ millimeters) Fraction for U-3at-D1 Characterization Samples ........................... B-2

B-3 Bulk Density for U-3at-D1 Characterization Samples $\ldots \ldots \ldots \ldots \ldots \ldots \ldots$ B-3

B-4 Water Retention Relations for U-3at-D1 Characterization Samples ........... B-4

B-5 Hydraulic / Water Content Relations for U-3at-D1 Characterization Samples . . . . B-14

B-6 Volumetric Water content for U-3at-D1 Characterization Samples . . . . . . . . . . B-21

B-7 Water Potential for U-3at-D1 Characterization Samples ................ B-22

B-8 Stable Isotope Concentrations for U-3at-D1 Characterization Samples . . . . . . . B-23

B-9 Soil Chloride Concentrations for U-3at-D1 Characterization Samples . . . . . . . . B-24

B-10 Soil Carbonate Concentrations for U-3at-D1 Characterization Samples . . . . . . . B-25

B-11 Tritium Concentrations for U-3at-D1 Characterization Samples . . . . . . . . . . . B-26

B-12 Particle Density for U-3at-D2 Characterization Samples . . . . . . . . . . . B-27

B-13 Particle Size Distribution for the Fine Earth ( $<2$ millimeter) Fraction for U-3at-D2 Characterization Samples . . . . . . . . . . . . . . . . . . B-27

B-14 Bulk Density for U-3at-D2 Characterization Samples ................. B-28

B-15 Water Retention Relations for U-3at-D2 Characterization Samples . . . . . . . . B-29

B-16 Hydraulic Conductivity / Water Content Relations U-3at-D2

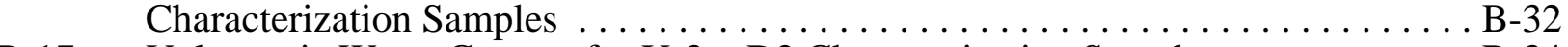

B-17 Volumetric Water Content for U-3at-D2 Characterization Samples . . . . . . . . . B-34

B-18 Water Potential for U-3at-D2 Characterization Samples . . . . . . . . . . . . . . B-34

B-19 Stable Isotope Concentrations for U-3at-D2 Characterization Samples . . . . . . . B-35

B-20 Soil Chloride for U-3at-D2 Characterization Samples ................. B-35

B-21 Soil Carbonate Concentrations for U-3at-D2 Characterization Samples . . . . . . . B-36

B-22 Tritium Concentrations for U-3at-D2 Characterization Samples . . . . . . . . . . . B-36 


\section{List of Acronyms and Abbreviations}

\begin{tabular}{|c|c|}
\hline$\%$ & parts per thousand \\
\hline${ }^{\circ} \mathrm{C}$ & degrees Celsius \\
\hline${ }^{\circ} \mathrm{F}$ & degrees Fahrenheit \\
\hline${ }^{18} \mathrm{O}$ & oxygen-18 \\
\hline $\mathrm{BN}$ & Bechtel Nevada \\
\hline CAU & casing-advance under-reaming \\
\hline $\mathrm{cm}$ & centimeter \\
\hline $\mathrm{D}$ & deuterium \\
\hline DOE & U.S. Department of Energy \\
\hline $\mathrm{ft}$ & foot (feet) \\
\hline I.D. & inner diameter \\
\hline in. & inch(es) \\
\hline $\mathrm{kg} / \mathrm{m}^{3}$ & kilograms per cubic meter \\
\hline LANL & Los Alamos National Laboratory \\
\hline LMWL & local meteoric water line \\
\hline $\mathrm{m}$ & meter(s) \\
\hline $\mathrm{m}^{3} / \mathrm{m}^{3}$ & cubic meters per cubic meter \\
\hline $\mathrm{mm}$ & millimeter(s) \\
\hline $\mathrm{MPa}$ & MegaPascals \\
\hline NNSA/NSO & National Nuclear Security Administration Nevada Site Office \\
\hline NTS & Nevada Test Site \\
\hline O.D. & outer diameter \\
\hline $\mathrm{pCi} / \mathrm{L}$ & picoCuries per liter \\
\hline REECo & Reynolds Engineering and Electrical Company, Inc. \\
\hline RWMS & Radioactive Waste Management Site \\
\hline SMOW & standard mean ocean water \\
\hline
\end{tabular}


This page intentionally left blank. 


\subsection{Introduction}

The work described in this document was conducted by personnel of the Bechtel Nevada (BN) Environmental Management Program at the Nevada Test Site (NTS). The work was conducted for the U.S. Department of Energy, National Nuclear Security Administration Nevada Site Office (NNSA/NSO; formerly U.S. Department of Energy [DOE], Nevada Operations Office) Waste Management Division.

A document titled "Hydrogeologic Characterization of the Unsaturated Zone at the Area 3 Radioactive Waste Management Site” was prepared by BN in February 1998, and assigned the document number DOE/NV/11718--210. This document included several data reports that addressed various portions of the Area 3 Radioactive Waste Management Site (RWMS), some of which were assigned separate document numbers. To permit public access to these data and to relieve confusion caused by this arrangement of nested documents, four reports within the larger document, of which this is one, are being updated and released separately.

This document was originally prepared by BN under the same title in February 1998, and was assigned the document number DOE/NV/11718--199. This report has been updated to conform to current editorial standards of BN and the NNSA/NSO, and to facilitate public distribution of the data contained herein. No new data have been added to this report, though additional relevant studies of the area have been conducted in the intervening years.

\subsection{Project Description}

This report provides qualitative analyses and preliminary interpretations of hydrogeologic data obtained from two boreholes drilled at an angle to penetrate the disturbed alluvial materials beneath the U-3at subsidence crater in the Area 3 RWMS. The U-3at crater was being used as a disposal site for low-level bulk radioactive waste, and the borehole angles were selected so that the waste disposed in the crater would not be disturbed. Borehole U-3at-D1 was drilled to a slant depth of 182.6 meters (m) (599 feet [ft]), which equates to a vertical depth of approximately $147.3 \mathrm{~m}$ (483.3 ft). Borehole U-3at-D2 was drilled nearby to a slant depth of $91.1 \mathrm{~m}$ (298.8 ft), which equates to a vertical depth of $78.3 \mathrm{~m}$ (256.9 ft). The second borehole was drilled to verify data from the first. Throughout this report, boreholes U-3at-D1and U-3at-D2 will be referred to as boreholes D1 and D2, respectively. Figure 1-1 shows the location of the Area 3 RWMS within the NTS. Figure 1-2 shows the locations of the subsidence craters and exploratory boreholes in the Area 3 RWMS facility.

\subsection{Purpose and Justification}

The Area 3 RWMS includes seven subsidence craters, five of which have been used for the disposal of low-level bulk radioactive waste (U-3ah, U-3at, U-3ax, U-3bh, and U-3bl). A waste cell was formed from the U-3at and U-3ah craters by excavating soil between the two adjacent subsidence craters to form a single cell. Disposal in the combined U-3ah/at unit began in 1988. 


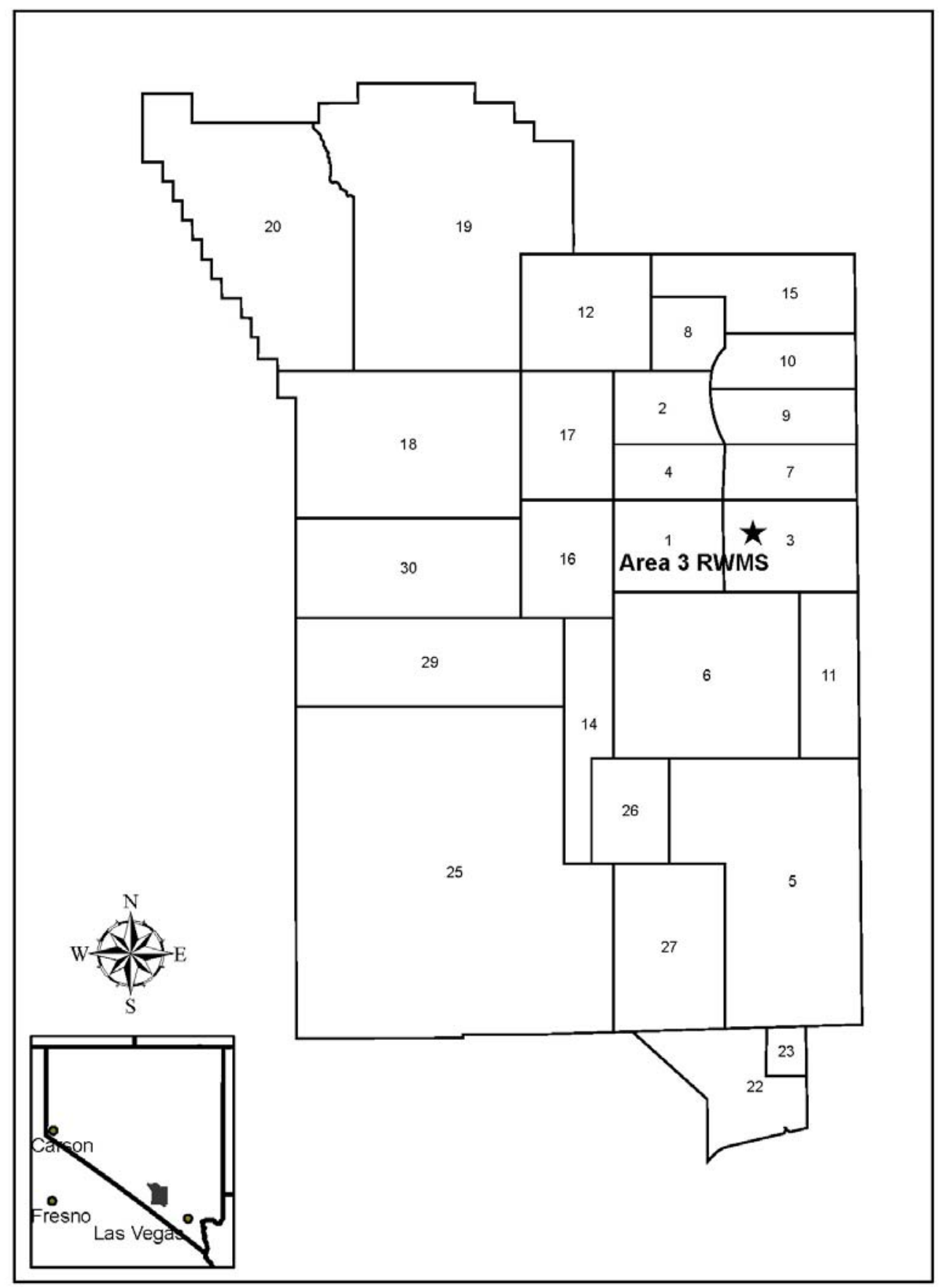

Figure 1-1

Location of the Area 3 Radioactive Waste Management Site at the Nevada Test Site 


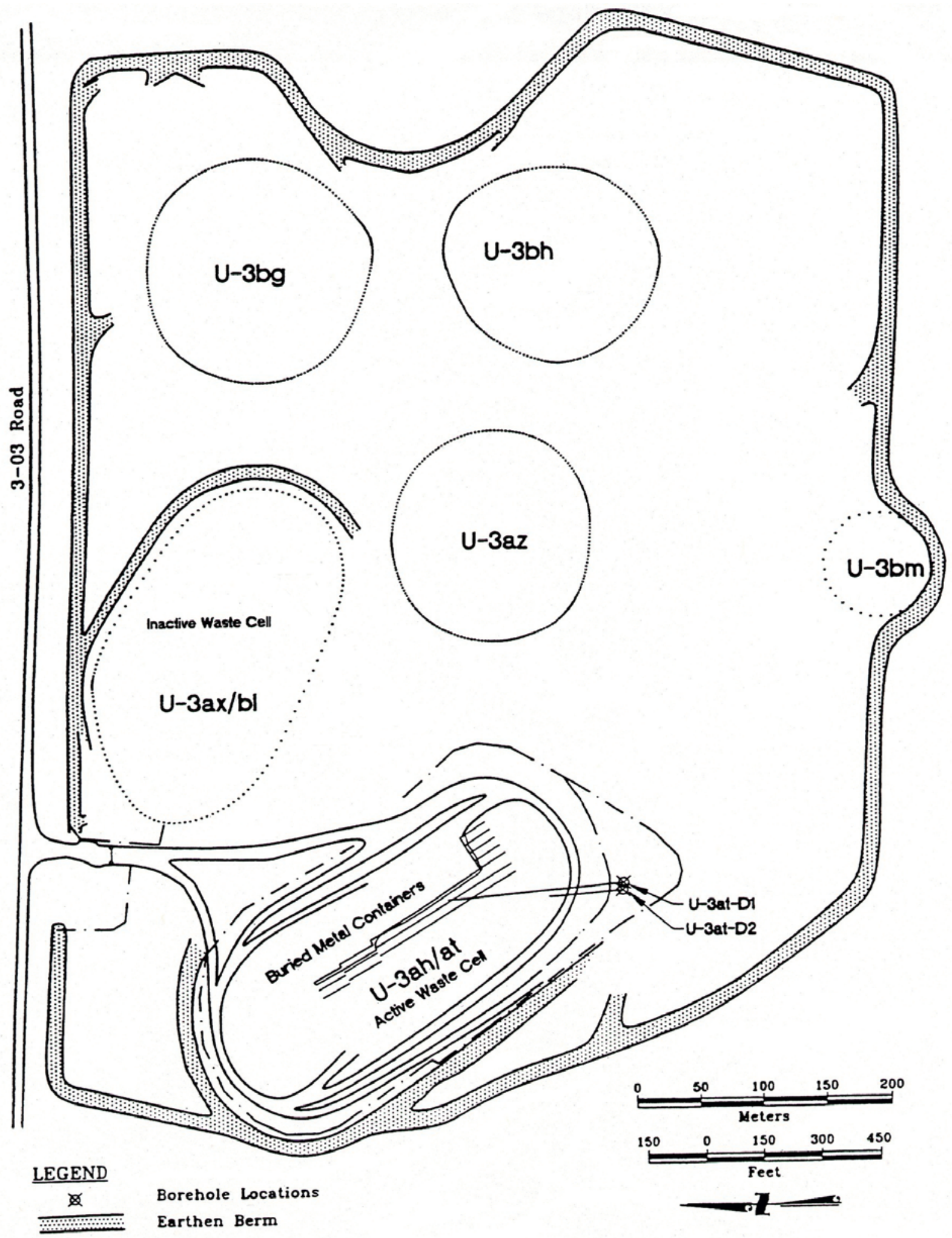

Figure 1-2

Map of Area 3 Radioactive Waste Management Site Showing Locations of Characterization Boreholes 
Waste forms consist primarily of contaminated soil, concrete, scrap metal, cables, construction debris, and containerized waste. Disposal cell U-3ah/at is currently being used for disposal of bulk, low-level radioactive waste from the NTS and approved offsite generators (DOE, 1996a).

A performance assessment is required by DOE Order 435.1, "Radioactive Waste Management" (DOE, 2001), for radioactive wastes disposed on or after September 26, 1988. The requirement for a composite analysis, which evaluates radionuclide inventories from all sources interacting with a given disposal site, is set out in DOE (1996b). The characterization data from this site were used in the performance assessment and in the composite analysis (Shott et al., 1997) for development of a conceptual hydrogeologic model, and provided estimates of the physical and hydraulic characteristics for flow and transport simulations. In addition, characterization data from the Area 3 RWMS site will be used in future closure design activities.

Site characterization at disposal units within the Area 3 RWMS must address the possibility that subsidence craters and their respective alluvial chimneys (regions of alluvium lying between the collapsed subsurface cavity created by the detonation of a nuclear device and the corresponding subsidence crater) act as pathways for contaminant migration. Researchers have suggested that chimneys might provide enhanced pathways for the migration of water into the uppermost aquifer (Borg et al., 1976; Tyler et al., 1992). Boreholes D1 and D2 were drilled and sampled to

obtain data on the hydrogeologic conditions of alluvium beneath the waste disposal crater, within the U-3at chimney, to help address this issue

\subsection{Data Objectives of the Project}

The data objectives listed below were identified to ensure that the appropriate data were collected during drilling to support site characterization.

- Obtain core samples on which to measure physical and hydrogeologic properties of alluvial materials from the chimney in the upper vadose zone.

- Measure concentrations of environmental tracers and hydrogeologic parameters in the core samples to estimate soil water fluxes in the upper vadose zone.

- Determine if contaminants, whether from the disposal unit itself or from nuclear testing, are present below the U-3ah/at waste disposal unit.

In addition, Los Alamos National Laboratory (LANL) conducted a review of data related to the construction and execution of the underground nuclear test that produced the U-3at subsidence crater, to determine if anything related to the test could produce preferential pathways for contaminant transport from the disposal unit (Plannerer, 1996). 


\subsection{Scope of Report}

This report includes the following information:

- Summary of the LANL underground test review.

- Descriptions of the drilling, sampling, and laboratory testing methods

- Preliminary interpretations of hydrogeologic data

- Appendices containing data obtained from the boreholes and sample laboratory tests.

\subsection{Site Description}

The Area 3 RWMS is located in Yucca Flat on the NTS in Nye County, Nevada (Figure 1-3).

The topography of the region is distinguished by north-south trending mountain ranges separated by alluvial valleys. The geology of Yucca Flat in the vicinity of the RWMS is characterized by thick sections of sedimentary rocks overlain by volcanic rocks and deposits of alluvium consisting of post-volcanic sands and gravels (DOE, 1996a). At the Area 3 RWMS, the alluvium is over $304.8 \mathrm{~m}(1,000 \mathrm{ft})$ thick, and the depth to groundwater is about $487.7 \mathrm{~m}$ (1,600 ft). Precipitation at this site averages 159 millimeters per year (6.3 inches per year) and monthly average temperatures range from 2 degrees Celsius $\left({ }^{\circ} \mathrm{C}\right)\left[36\right.$ degrees Fahrenheit $\left.\left[{ }^{\circ} \mathrm{F}\right]\right)$ in January to $25^{\circ} \mathrm{C}\left(77^{\circ} \mathrm{F}\right)$ in July (SORD website).

Figure 1-2 shows the location of U-3at, one of seven subsidence craters within the boundaries of the Area 3 RWMS (see Section 2.1). Five of the craters, including two pairs of conjoined craters, have been used for the disposal of low-level bulk radioactive waste. 
This page intentionally left blank. 


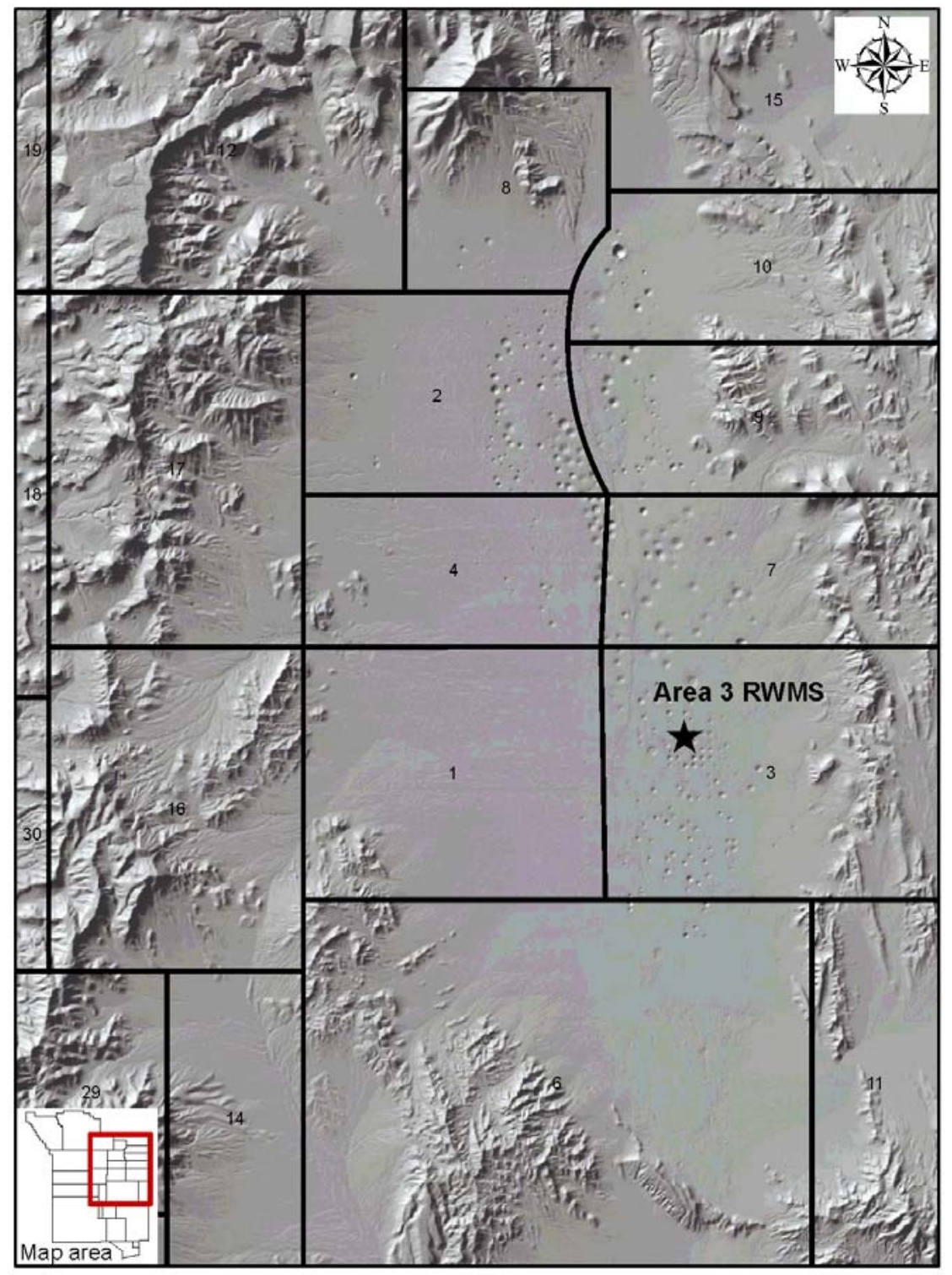

Figure 1-3

Location of the Area 3 Radioactive Waste Management Site in Yucca Flat 
This page intentionally left blank. 


\subsection{Test Review and Borehole Construction}

Included in this data report are a summary of information compiled regarding the nuclear test that led to the formation of subsidence crater U-3at (Section 2.1) and data from U-3at-D1 and U-3at-D2 samples. These data comprise field descriptions and results of laboratory analyses of 56 cores obtained from Borehole U-3at-D1 and 13 cores obtained from Borehole U-3at-D2 (Section 2.2). These data were used in the Area 3 performance assessment and the composite analysis (Shott et al., 1997) to develop the conceptual hydrogeologic model and provide physical and hydraulic characteristics for flow and transport simulations.

\subsection{Review of the U-3at Underground Nuclear Test}

\subsubsection{General Information on Subsidence Craters}

Craters within the Area 3 RWMS were formed by testing of nuclear devices in the early 1960s. These tests were conducted hundreds of meters below the ground surface in shafts bored vertically into the alluvium. Upon detonation of a nuclear device underground, extremely high pressures and temperatures produce a cavity in the alluvium. When the gas pressure dissipates to a point at which it can no longer support the overburden, the top of the cavity collapses and the void region propagates upward to the surface, forming a saucer-like subsidence crater on the surface (U.S. Congress, 1989). The region through which the void propagates is referred to as the collapse zone or chimney. At the time of formation, the seven craters within the Area 3 RWMS ranged from 121.9 to $176.8 \mathrm{~m}$ (400 to $580 \mathrm{ft}$ ) in diameter and from 14.0 to $32.0 \mathrm{~m}$ (46 to $105 \mathrm{ft}$ ) in depth (Plannerer, 1996).

\subsubsection{Test Construction Information}

A review of available data describing U-3at site construction, diagnostics hardware, stemming, explosion phenomenology, and post-shot activities was prepared by Plannerer (1996). For brevity, only the principal findings of this review are summarized here.

The U-3at emplacement hole, initially a small-diameter pilot hole, was begun on January 10, 1962. After reaming of the pilot hole, the borehole diameter was $1.524 \mathrm{~m}$ (60 inches

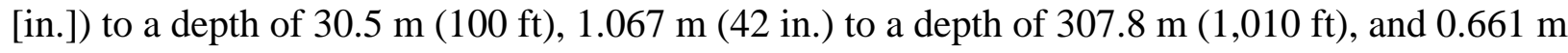
(26 in.) to a depth of $309.4 \mathrm{~m}(1,015 \mathrm{ft})$. Surface casing of 1.372-m (54-in.) outside diameter

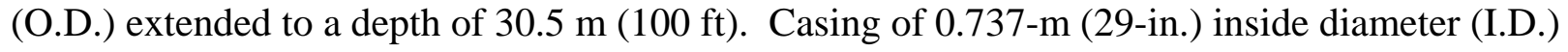
extended from $24.5 \mathrm{~m}(80.4 \mathrm{ft})$ to a depth of $306.3 \mathrm{~m}(1,005 \mathrm{ft})$. Casing sections were connected by welding. The emplacement hole was subsequently modified by extending the $0.737-\mathrm{m}$ (29-in.) I.D. casing to the surface. This casing joint was not welded.

Four satellite boreholes intended for instrumentation associated with the nuclear test were drilled along a radial extending north from the emplacement hole. The closest borehole, U-3at-1, was located $7.53 \mathrm{~m}(24.7 \mathrm{ft})$ from the U-3at emplacement hole. It was drilled to a depth of $322.5 \mathrm{~m}$ (1,058 ft) and 0.273-m (103/4-in.) I.D. casing was installed to $217.9 \mathrm{~m}$ (715 ft). Borehole U-3at-2 
was drilled to a depth of $325.5 \mathrm{~m}$ (1,068 ft) and 0.273-m (103/4-in.) I.D. casing was installed to $243.5 \mathrm{~m}$ (799 ft). Borehole U-3at-3 was drilled to a depth of $189.9 \mathrm{~m}$ (623 ft) and 0.273-m (103/4-in.) I.D. casing was installed to $106.7 \mathrm{~m}$ (350 ft). This hole was subsequently plugged with cement from the bottom of the casing to the surface and abandoned. The distal borehole, U-3at-3s, was located $20.2 \mathrm{~m}$ (66.3 ft) north of the emplacement hole. It was drilled to a depth of $320.0 \mathrm{~m}(1,050 \mathrm{ft})$ and $0.273-\mathrm{m}(103 / 4-$ in.) I.D. casing was installed to $243.8 \mathrm{~m}(800 \mathrm{ft})$.

The device was located in a canister and inserted, along with a rack of instruments above it, into the emplacement hole to the depth of $301.1 \mathrm{~m}$ (988 ft). The canister and rack were surrounded by 2.29 cubic meters ( 80.9 cubic feet) of magnetite sand. Above the magnetite were emplaced alternating layers of coarse and fine sand. Layers of coarse sand were $30.5 \mathrm{~m}(100 \mathrm{ft})$ thick, and the layers of fine sand were $1.8 \mathrm{~m}(6 \mathrm{ft})$ thick. The satellite holes were stemmed by backfilling them with sand until a thickness of $30.7 \mathrm{~m}$ (100.6 ft) accumulated above the instrumentation, then filling with cement from the top of the sand to the surface.

\subsubsection{Post-Test Information}

The JERBOA device was detonated in Emplacement Hole U-3at on March 1, 1963. Cavity collapse occurred 35.3 minutes later, forming a collapse zone (rubble chimney) and a surface subsidence crater. No additional subsidence has been reported. The crater was generally symmetrical, with an average radius of $84.4 \mathrm{~m}(277 \mathrm{ft})$, a depth of $32.3 \mathrm{~m}(106 \mathrm{ft})$, and an estimated volume of 246,040 cubic meters (8,694,010 cubic feet). The crater diameter along the east-west axis was approximately 1.2 times that along the north-south axis. This slight asymmetry was attributed to differences in the subsidence along the western edges of the crater. A contour map of the crater and an average crater profile can be found in Plannerer (1996). An analysis of the subsidence indicated that the overburden response to the JERBOA explosion was typical. There was no evidence of any release of radioactivity resulting from the test.

Two vertical post-shot boreholes, U-3at-PS\#1 and U-3at-PS\#2, were drilled from the crater floor near the emplacement hole, starting within 10.3 hours of the detonation. At completion, Borehole U-3at-PS\#1 extended to a depth of $335.6 \mathrm{~m}$ (1,101 ft), and 0.349-m (133/4-in.) I.D. casing was installed in the upper $12.2 \mathrm{~m}$ (40 ft). Post-shot Borehole U-3at-PS\#2 extended to a depth of $302.4 \mathrm{~m}$ (992 ft) and 0.273-m (103/4-in.) I.D. casing was installed in the upper $18.3 \mathrm{~m}$ (60 ft). Post-shot Borehole U-3at-PS\#3 was drilled at an angle from a point outside the crater rim toward the explosion point. This borehole extended to a slant depth of $382.8 \mathrm{~m}(1,256 \mathrm{ft})$, which corresponds to a vertical depth of $352.0 \mathrm{~m}$ (1,155 ft). Casing (0.178-m [7-in.] O.D.) in

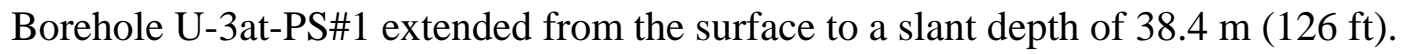

Plannerer (1996) noted that the post-shot drilling records indicate a loss of drilling fluid circulation occurred in all three post-shot boreholes at similar depths. Loss of circulation in Borehole U-3at-PS\#1 was first reported at $231.6 \mathrm{~m}$ (760 ft), in Borehole U-3at-PS\#2 at $234.7 \mathrm{~m}$ (770 ft), and in Borehole U-3at PS\#3 at a vertical depth of $246.9 \mathrm{~m}$ (810 ft). Plannerer (1996) suggested that the reported loss of circulation was attributable to characteristics of the geologic 
medium in that depth interval (231.6 to $246.9 \mathrm{~m}$ [760 to $810 \mathrm{ft}$ ), such as a zone of higher porosity or permeability.

\subsubsection{Potential for Preferential Pathways}

In his review of aspects of JERBOA construction and execution that could lead to preferential pathways in the collapse zone, Plannerer (1996) raised a particular concern with an unwelded casing joint in Emplacement Hole U-3at. During the construction of the emplacement hole, a decision was made to extend the 0.737-m (29-in.) inner casing from the disconnect collar at $24.4 \mathrm{~m}$ (80 ft) to the surface. This extension consisted of stabbing a smaller diameter casing into the disconnect collar and sealing it with gypsum cement. A worst-case scenario is suggested by Plannerer (1996) in which the shock wave separated the metal casing and fractured the cement, providing a pathway between the inner casing and the surface casing.

Test instrumentation for JERBOA required 37 down-hole cables. Plannerer (1996) noted that cables were known pathways for preferential transport of radioactive gases, and gas blocks were installed at the surface between the well head and the recording trailer. No records documenting the use of down-hole gas blocks in cables or cable fan-outs were found. Whether a pathway available for high-pressure gases would also be a preferential pathway for the movement of water is uncertain.

No records documenting the abandonment of the post-shot boreholes were recovered. The common practice at the time was to leave the boreholes unplugged, but with some type of closure at the top of the short surface casing (Hawkins,1994).

\subsection{Chimney Characterization Boreholes}

Drilling of Borehole U-3at-D1 began on June 18, 1996, adjacent to the crater formed by the JERBOA test in Emplacement Hole U-3at. The borehole was drilled at an angle of approximately 35 degrees to pass under the waste cell and into the collapse zone below the crater. To minimize disturbance of the core samples, drilling was done by a method that used only air as the drilling fluid. Only small amounts of oil were used to lubricate the drill string. A second borehole, U-3at-D2, was drilled and sampled over a shorter interval to confirm that core samples from Borehole D1 had not been affected by water condensed in the compressed air system or by excess lubrication oil, after indications of excess water had been observed in the interval 50.9 to $71.6 \mathrm{~m}$ (167 to $235 \mathrm{ft}$ ) in Borehole D1. The locations of boreholes D1 and D2 are shown in Figure1-2, and coordinates, land surface elevations, and depths are provided in Table 2-1. These boreholes are two of seven characterization boreholes shown in Figure 1-2 that were drilled and sampled in the Area 3 RWMS. Characterization data from these other boreholes are provided in BN (1998a, 1998b, 2005). 
Table 2-1

Location and Depth of Characterization Boreholes U-3at and U-3at-D2

\begin{tabular}{||c|c|c|c|c||}
\hline \multirow{2}{*}{ Borehole } & \multirow{2}{*}{$\begin{array}{c}\text { Total Vertical } \\
\text { Depth }\end{array}$} & \multirow{2}{*}{$\begin{array}{c}\text { Land Surface } \\
\text { Elevation Above } \\
\text { meters (feet) }\end{array}$} & $\begin{array}{c}\text { Sea Level } \\
\text { meters (feet) }\end{array}$ & $\begin{array}{c}\text { Nevada State Central Zone } \\
\text { Coordinates (NAD 27) }\end{array}$ \\
\cline { 4 - 5 } & & $\begin{array}{c}\text { North } \\
\text { meters (feet) }\end{array}$ & $\begin{array}{c}\text { East } \\
\text { meters (feet) }\end{array}$ \\
\hline \hline U-3at-D1 & 147.3 & $\begin{array}{c}1,222.6 \\
(4,011)\end{array}$ & $\begin{array}{c}254,647.95 \\
(835,457.48)\end{array}$ & $\begin{array}{c}209,333.82 \\
(686,789.39)\end{array}$ \\
\hline U-3at-D2 & $(483.3)$ & $\begin{array}{c}1,222.6 \\
(4,011)\end{array}$ & $\begin{array}{c}254,648.11 \\
(835,458.00)\end{array}$ & $\begin{array}{c}209,327.85 \\
(686,769.80)\end{array}$ \\
\hline
\end{tabular}

\subsubsection{Drilling and Sampling Methods for Borehole U-3at-D1}

Drilling of the characterization Borehole D1 was initiated by setting 30.5-centimeter $(\mathrm{cm})$ (12-in.) diameter surface casing at a 30-degree angle in a 2.9-m (9.5-ft ) deep trench located near the southern edge of the U-3at crater rim. Surface casing was used to reduce dust and help guide the drill casing. From this depth, the borehole was drilled with an Ingersol-Rand T-4 rig using a casing-advance under-reaming (CAU) system. The method consisted of attaching an air percussion hammer to a drill rod within a 27.0-cm (10.63-in.) diameter casing. A drive shoe was attached to the bottom of the casing. The air percussion hammer drilled a hole slightly larger than the casing and advanced the casing by impacting on the shoe. Drill cuttings were forced to the surface through the casing using only air as the drilling fluid. The casing was advanced until a coring depth was reached. The major advantage of a CAU system is that it prevents the borehole from collapsing during drilling. Therefore, CAU systems are well suited for use in unconsolidated alluvium, where borehole collapse is a constant risk.

Core samples were obtained at approximately 3.05-m (10-ft) intervals in a 0.76-m (2.5-ft) long by 11.43-cm (4.5-in.) O.D. solid tube core barrel containing ten clear polycarbonate liner segments $7.62 \mathrm{~cm}$ (3-in.) long by 8.89-cm (3.5-in.) O.D. The core barrel was driven into the bottom of the hole using the air percussion hammer. After retrieving the core barrel, the liner segments were removed using a pneumatic core extruder. This method was chosen because it provides good core recovery and reduces the disturbance of hydrogeologic conditions and properties of relatively dry, coarse-grained, unconsolidated alluvial samples (Hammermeister et al., 1986).

A geologic description of the core was made by examining the open ends of each liner segment. Geologic description consisted of noting visual indications of moisture content, particle size distribution, lithology, sorting, grain shape, and any anomalies including indications of preferential pathways. The liner segments were then capped, taped, labeled with sample identification numbers, and sealed in tubular plastic laminate for shipping to laboratories for analyses. Sampling in Borehole D1 began on June 18, 1996, at a borehole length of $6.4 \mathrm{~m}$ $(21 \mathrm{ft})$, which corresponds to a vertical depth of $5.2 \mathrm{~m}(17 \mathrm{ft})$. At a vertical depth of $46.3 \mathrm{~m}$ 
(152 ft), the drive casing was switched to 21.9-cm (8.63-in.) O.D., and drilling proceeded with this size casing to a final vertical depth of $147.3 \mathrm{~m}(483.3 \mathrm{ft})$.

During drilling of Borehole D1, unusually wet alluvium was observed on the drill bit when it was returned to the surface from a vertical depth of approximately $50.9 \mathrm{~m}(167 \mathrm{ft})$. Wet alluvium was observed on the drill bit at subsequent sampling intervals to a vertical depth of

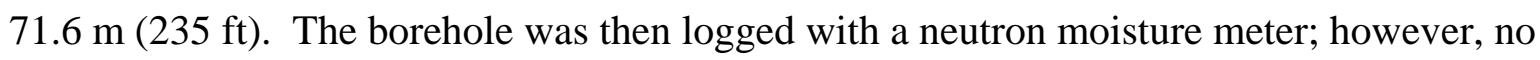
zones of anomalously high water content were observed. Because the usual practice was to take a drive core sample from the point at which drilling stopped, observations of wet alluvium on the drill bit raised concerns that water condensed from the compressed air or excess lubrication oil from drilling may have infiltrated as far as the sample segments. Air dryers were restored, air compressor separators were drained, and the amount of lubricant oil used was reduced for drilling of the remainder of the borehole.

\subsubsection{Drilling and Sampling of Borehole U-3at-D2}

To ensure that representative characterization samples were obtained between vertical depths of 50.9 and $73.8 \mathrm{~m}$ (167 and $242 \mathrm{ft}$ ), a second borehole was drilled to obtain duplicate samples over this depth interval. Borehole D2 was begun by placing a 2.1-m (7.0-ft) length of 27.3-cm (10.75-in.) O.D. surface casing in a trench located $6.0 \mathrm{~m}$ (19.8 ft) west of Borehole D1. Drilling of Borehole D2 began on August 13, 1996, using 21.9-cm (8.63-in.) O.D. casing. The same drilling and sampling methods were used for this borehole as for Borehole D1. Samples were collected from a vertical depth of $47.5 \mathrm{~m}$ (156 ft) to the final depth of $78.3 \mathrm{~m}(257 \mathrm{ft})$.

Figure 2-1 is a schematic representation depicting the locations of boreholes D1 and D2 with respect to U-3at crater and the estimated margins of the collapse zone and cavity.

\subsection{Laboratory Tests}

Drillers completed 56 core runs in Borehole D1, and 13 core runs in Borehole D2. Although core recovery was generally less than 100 percent, recovery was sufficient in all runs to meet minimum sample requirements of the analytical laboratories. The analytical method, source of the method, and the laboratory performing the analysis are shown in Table 2-2 for each of the characterized properties. Volumetric water content and bulk density were measured on two cores from each core run to provide better knowledge of the variation of these properties with depth. BN audited and approved the quality assurance programs for the two laboratories, Huffman Laboratories and Northwest Environmental Services, Testing and Training. 


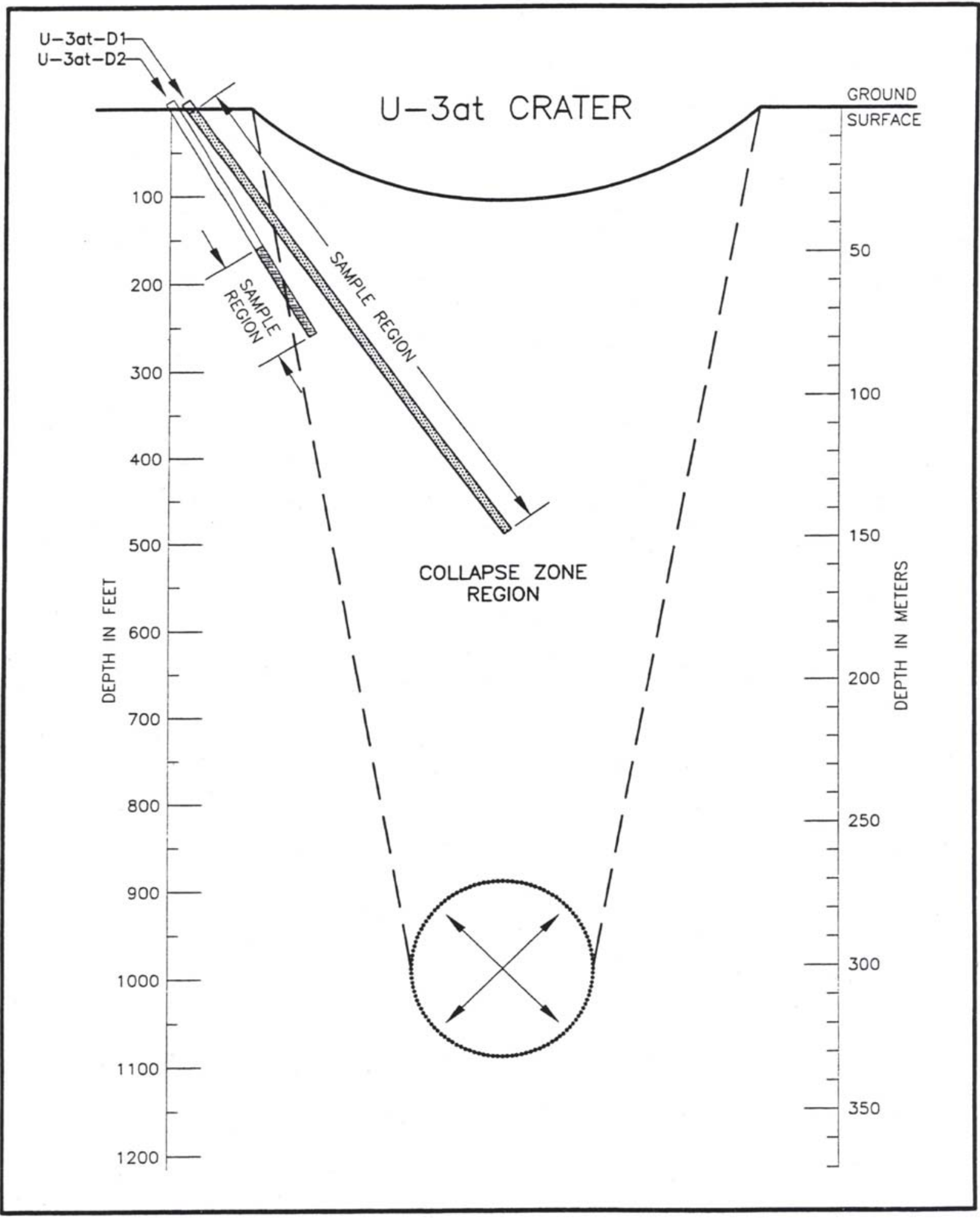

Figure 2-1

Schematic Showing Locations of Boreholes U-3at-D1 and U-3at-D2 with Respect to the U-3at Crater and Estimated Margins of the Collapse Zone and Cavity 
Table 2-2

Methods of Analysis

\begin{tabular}{|c|c|c|c|}
\hline $\begin{array}{c}\text { Characteristic } \\
\text { or Property }\end{array}$ & Method & Reference & Laboratory \\
\hline $\begin{array}{l}\text { Geologic } \\
\text { Description }\end{array}$ & Visual / Manual & $\begin{array}{l}\text { ASTM, 1990. "Standard Recommended Practice for the } \\
\text { Description of Soils-visual Manual Procedure." D 2488- } \\
\text { 90. In: } 1990 \text { Annual Book of ASTM Standards. Vol. } \\
\text { 04.08. American Society for Testing and Materials, } \\
\text { Philadelphia, Pennsylvania. }\end{array}$ & $\mathrm{BN}^{\mathrm{a}}$ \\
\hline Particle Density & Liquid Pycnometer & $\begin{array}{l}\text { Snyder, K. E., G. E. Byers, and R. D. van Remortel, } \\
\text { 1996. Handbook of Laboratory Methods of Soil Analysis. } \\
\text { U. S. Department of Energy Report DOE/NV 11718-074, } \\
\text { Las Vegas, Nevada. }\end{array}$ & $\mathrm{HL}^{\mathrm{b}}$ \\
\hline Bulk Density & Core & $\begin{array}{l}\text { Blake, G. R. and K. H. Hartge, } 1986 \text {. "Bulk Density." In: } \\
\text { Klute, A. L. (ed), Methods of Soil Analysis, Part } 1 \text {, } \\
\text { Physical and Mineralogical Methods. } 2^{\text {nd }} \text { Ed. American } \\
\text { Society of Agronomy, Madison, Wisconsin. }\end{array}$ & $\mathrm{NESTT}^{\mathrm{C}} / \mathrm{BN}$ \\
\hline Water Retention & Centrifugation & $\begin{array}{l}\text { Hoffman, R. N. A., 1963. "A Technique for the } \\
\text { Determination of Capillary Pressure Curves Using a } \\
\text { Constantly Accelerated Centrifuge." Society of Petroleum } \\
\text { Engineering Journal, vol. 3, pp. 227-235. }\end{array}$ & NESTT \\
\hline $\begin{array}{l}\text { Hydraulic } \\
\text { Conductivity } \\
\text { Saturated }\end{array}$ & Constant Head & $\begin{array}{l}\text { ASTM, 1974. "Test Method for Permeability of Granular } \\
\text { Soils (Constant Head)." D2434-68. In: } 1987 \text { Annual } \\
\text { Book of ASTM Standards. Vol. 04.08. American Society } \\
\text { for Testing and Materials, Philadelphia, Pennsylvania. }\end{array}$ & NESTT \\
\hline $\begin{array}{l}\text { Hydraulic } \\
\text { Conductivity } \\
\quad \text { Unsaturated }\end{array}$ & Centrifugation & $\begin{array}{l}\text { Conca, J. L., and J. V. Wright, 1992. "Diffusion and Flow } \\
\text { in Gravel, Soil and Whole Rock." Applied Hydrology, } \\
\text { vol. 1, pp. 5-24 }\end{array}$ & NESTT \\
\hline Water Content & Volumetric & $\begin{array}{l}\text { Snyder, K. E., G. E. Byers, and R. D. van Remortel, } \\
\text { 1996. Handbook of Laboratory Methods of Soil Analysis. } \\
\text { U. S. Department of Energy Report DOE/NV 11718-074, } \\
\text { Las Vegas, Nevada. }\end{array}$ & NESTT/BN \\
\hline Water Potential & Water Activity Meter & $\begin{array}{l}\text { Snyder, K. E., G. E. Byers, and R. D. van Remortel, } \\
\text { 1996. Handbook of Laboratory Methods of Soil Analysis. } \\
\text { U. S. Department of Energy Report DOE/NV 11718-074, } \\
\text { Las Vegas, Nevada. }\end{array}$ & BN \\
\hline Chloride & $\begin{array}{l}\text { Ion } \\
\text { Chromatography }\end{array}$ & $\begin{array}{l}\text { Snyder, K. E., G. E. Byers, and R. D. van Remortel, } \\
\text { 1996. Handbook of Laboratory Methods of Soil Analysis. } \\
\text { U. S. Department of Energy Report DOE/NV 11718-074, } \\
\text { Las Vegas, Nevada. }\end{array}$ & $\mathrm{HL}$ \\
\hline Carbonate & Pressure Calcimeter & $\begin{array}{l}\text { Snyder, K. E., G. E. Byers, and R. D. van Remortel, } \\
\text { 1996. Handbook of Laboratory Methods of Soil Analysis. } \\
\text { U. S. Department of Energy Report DOE/NV 11718-074, } \\
\text { Las Vegas, Nevada. }\end{array}$ & $\mathrm{HL}$ \\
\hline Tritium & Liquid Scintillation & $\begin{array}{l}\text { Burg, W. P. 1994. "Liquid Scintillation Instrumentation } \\
\text { Method." In: DOE Methods for Evaluating Environmental } \\
\text { and Waste Management Samples. DOE/EM-089T, Rev. } \\
2 .\end{array}$ & $\mathrm{DRI}^{\mathrm{d}}$ \\
\hline
\end{tabular}

a Bechtel Nevada

b Huffman Laboratories Inc.

c Northwest Environmental Services, Testing and Training

d Desert Research Institute 
This page intentionally left blank. 


\subsection{Results}

Visual geologic descriptions of the core obtained from the characterization borehole were recorded on borehole log sheets, which are presented in Appendix A. No visual evidence of preferential pathways for water was observed in the cores. The results of laboratory tests on cores are presented in graphic form as figures in this section and are provided in tabular form in Appendix B. All results are presented in terms of the vertical depth of the sample calculated from the slant (drilled) depth.

\subsection{Geologic Properties of Borehole U-3at-D1}

The variation of particle density with depth for Borehole D1 is shown in Figure 3-1. Particle density values range from 2,180 to 2,540 kilograms per cubic meter $\left(\mathrm{kg} / \mathrm{m}^{3}\right)$. Values show no trends with depth and, on average, are slightly lower than particle densities previously observed for shallower sediments within the RWMS (BN, 1998a). Percentages of sand, silt, and clay for the fine-earth (less than 2 millimeter [mm]) fraction of the samples from Borehole D1 are shown in Figure 3-2. Results from this borehole are similar to others from the RWMS (BN, 1998a, 1998b, 2005), with particle size distribution being dominated by the 0.05 - to 2.0-mm size sand fraction. In general, the sand fraction ranges from approximately 61 to 94 percent, with an average of 81 percent. The silt and clay fractions range from approximately 2 to 28 percent, with the means of both fractions being 9 percent. These percentages are typical of a loamy sand to sandy loam texture (USDA, 1993). Dry bulk density for Borehole D1, shown in Figure 3-3, ranges from 1,330 to $2,055 \mathrm{~kg} / \mathrm{m}^{3}$, with no obvious trend with depth. The mean bulk density is $1,602 \mathrm{~kg} / \mathrm{m}^{3}$.

\subsection{Hydrogeologic Properties of Borehole U-3at-D1}

Water retention relations for samples from Borehole D1 are shown in Figures 3-4 through 3-9. This property, while variable, is relatively consistent for the cores tested and is typical of water retention relations for the other soils of similar texture.

The relationship between hydraulic conductivity and water content for Borehole D1 samples is shown in Figures 3-10 through 3-15. These hydraulic conductivity water-content relations were measured directly on samples and thus are not dependent on fitting model parameters to the water retention relations. The results are typical of sandy soil, with hydraulic conductivity decreasing rapidly as the soil dries. While variable, these relations show no trend with depth. These results reflect subtle, yet distinct, differences in hydraulic properties of the alluvium layers.

The variation of volumetric water content with depth for Borehole D1 is shown in Figure 3-16. The reported value of 0.005 cubic meters per cubic meter $\left(\mathrm{m}^{3} / \mathrm{m}^{3}\right)$ at a depth of $7.74 \mathrm{~m}(25.4 \mathrm{ft})$ is much lower than any water content value observed in near-surface soil and is probably the result of a laboratory error. Excluding this point, volumetric water content values range from 0.05 to $0.33 \mathrm{~m}^{3} / \mathrm{m}^{3}$ and tend to increase with depth. The trend in volumetric water content with depth is, on average, an increase of $0.065 \mathrm{~m}^{3} / \mathrm{m}^{3}$ per $100 \mathrm{~m}(328 \mathrm{ft})$ of depth. 


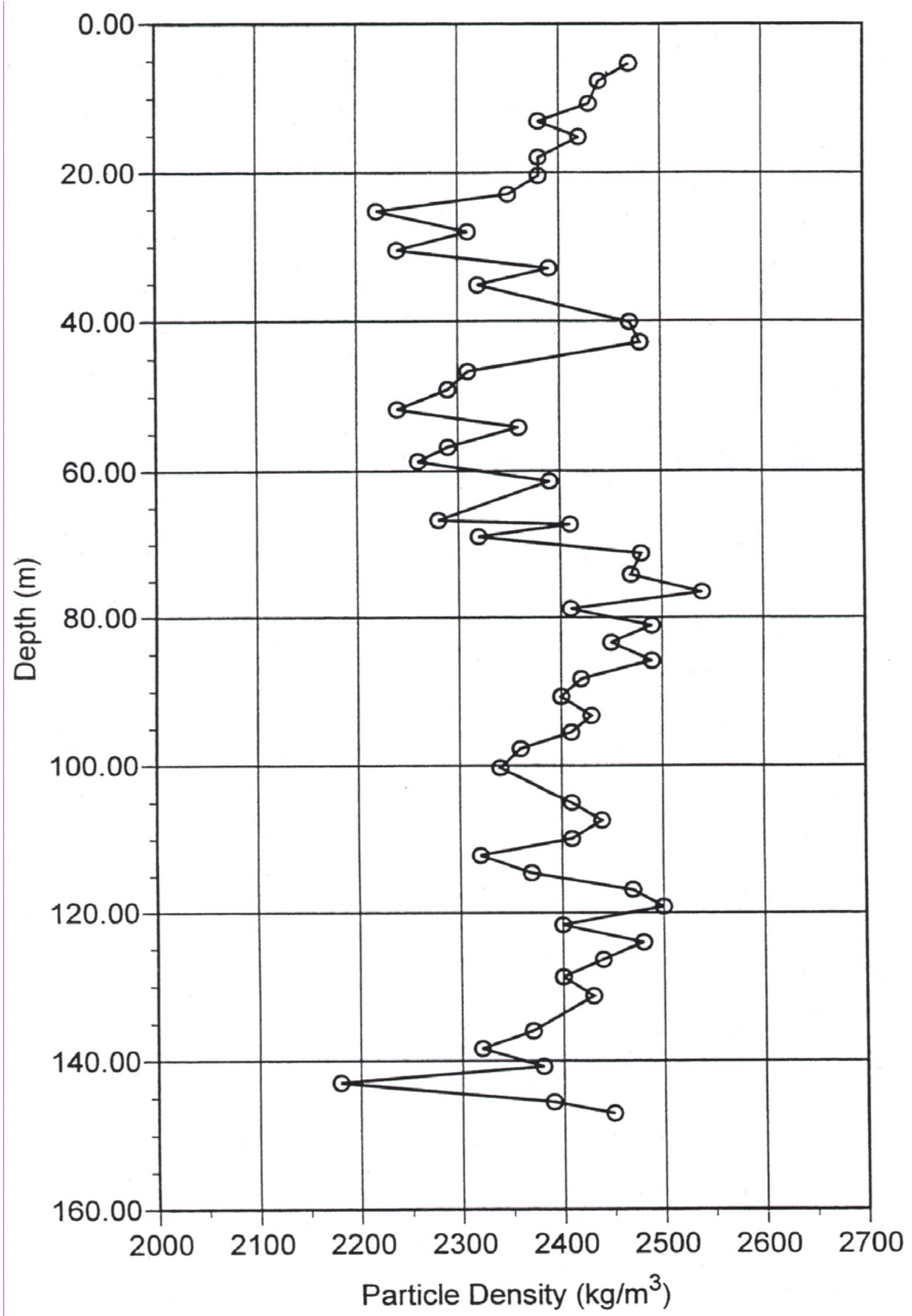

Figure 3-1

Particle Density versus Depth for U-3at-D1

(In kilograms per cubic meter) 


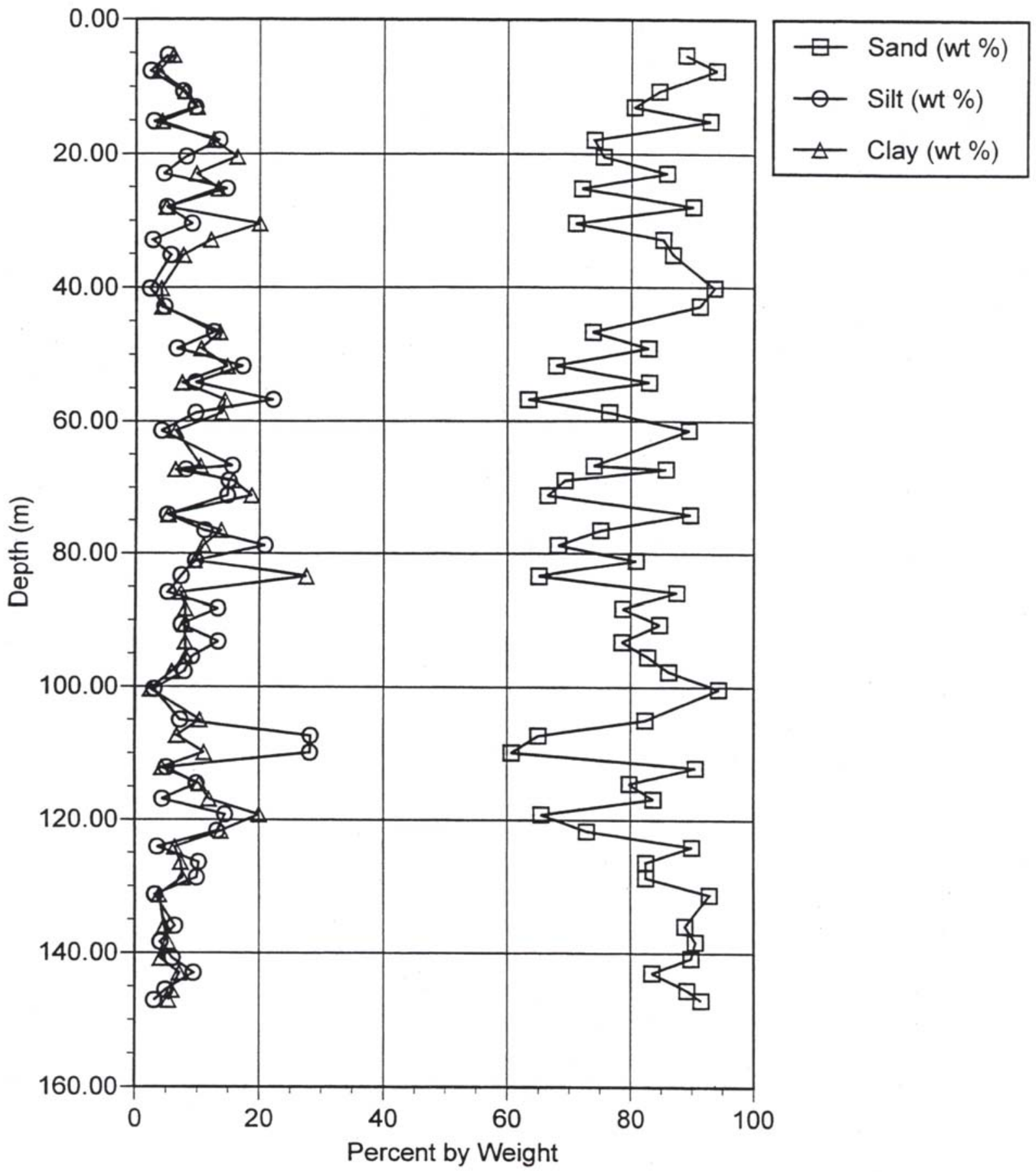

Figure 3-2

Sand, Silt and Clay Fractions versus Depth for U-3at-D1 


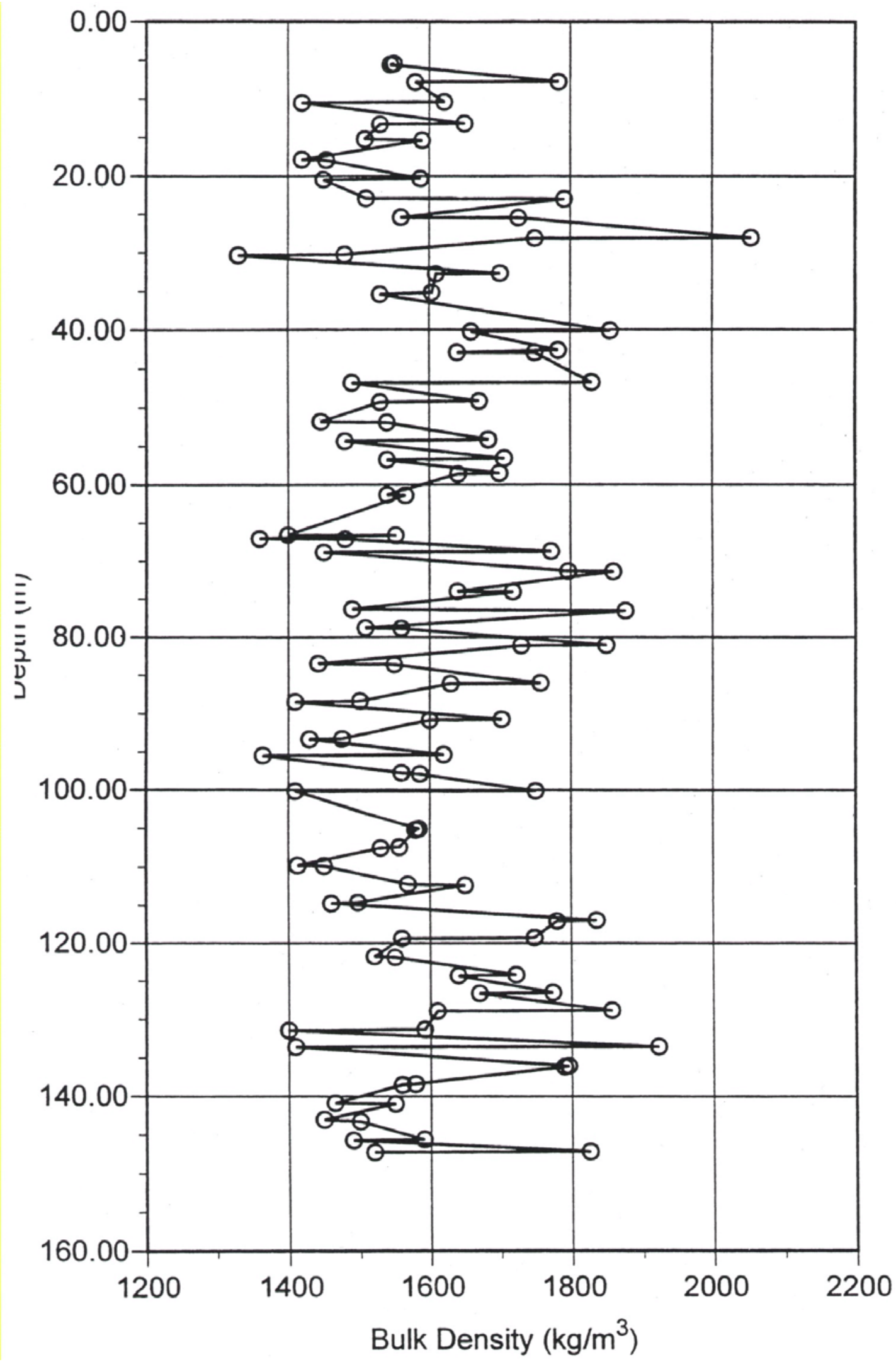

Figure 3-3

Dry Bulk Density versus Depth for U-3at-D1

(In kilograms per cubic meter) 


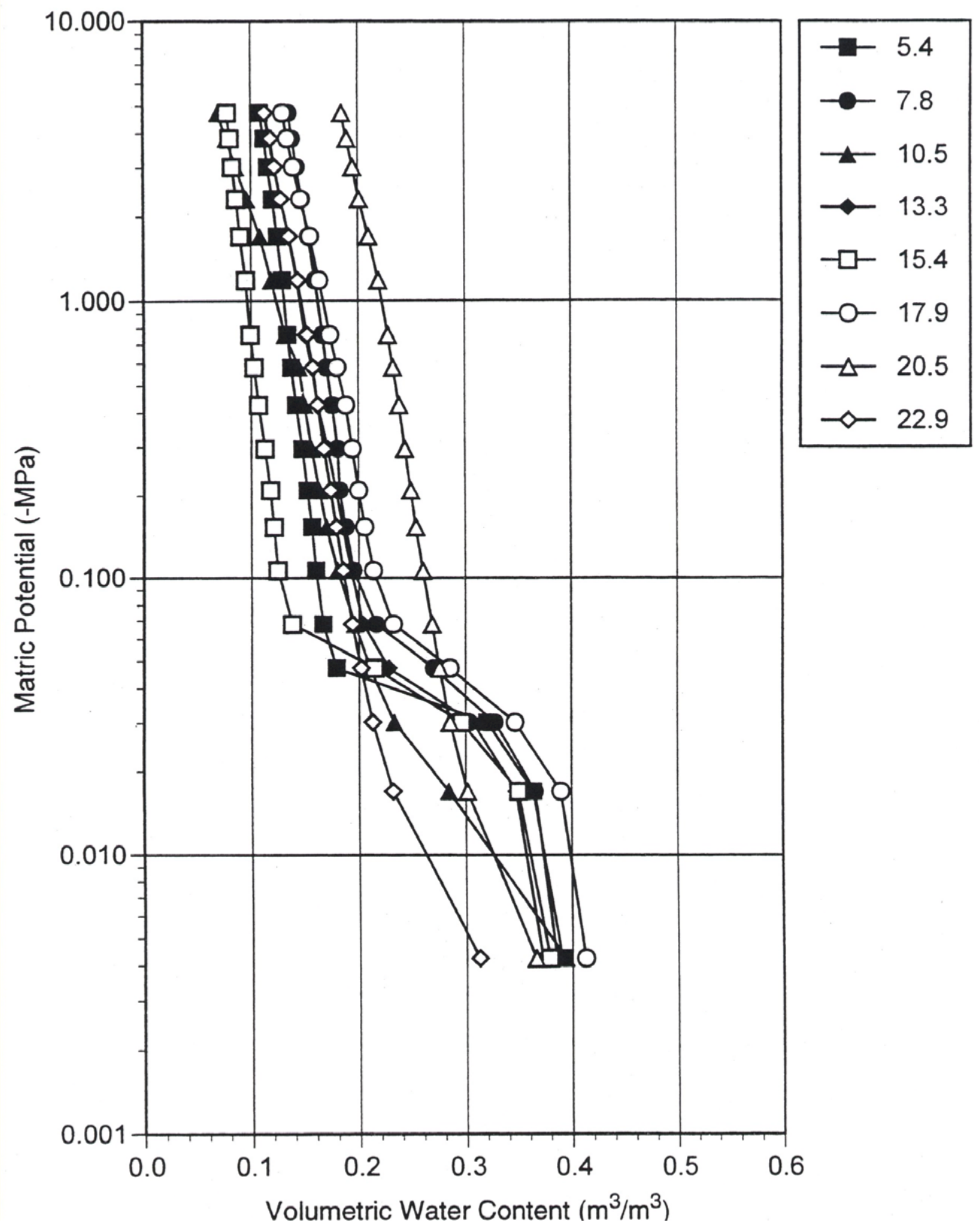

Figure 3-4

Water Retention Relations for U-3at-D1 Samples from 8 Depths from 5.4 to 22.9 Meters

(Depths as indicated by symbols; matric potential given in MegaPascals; water content given in cubic meters per cubic meter) 


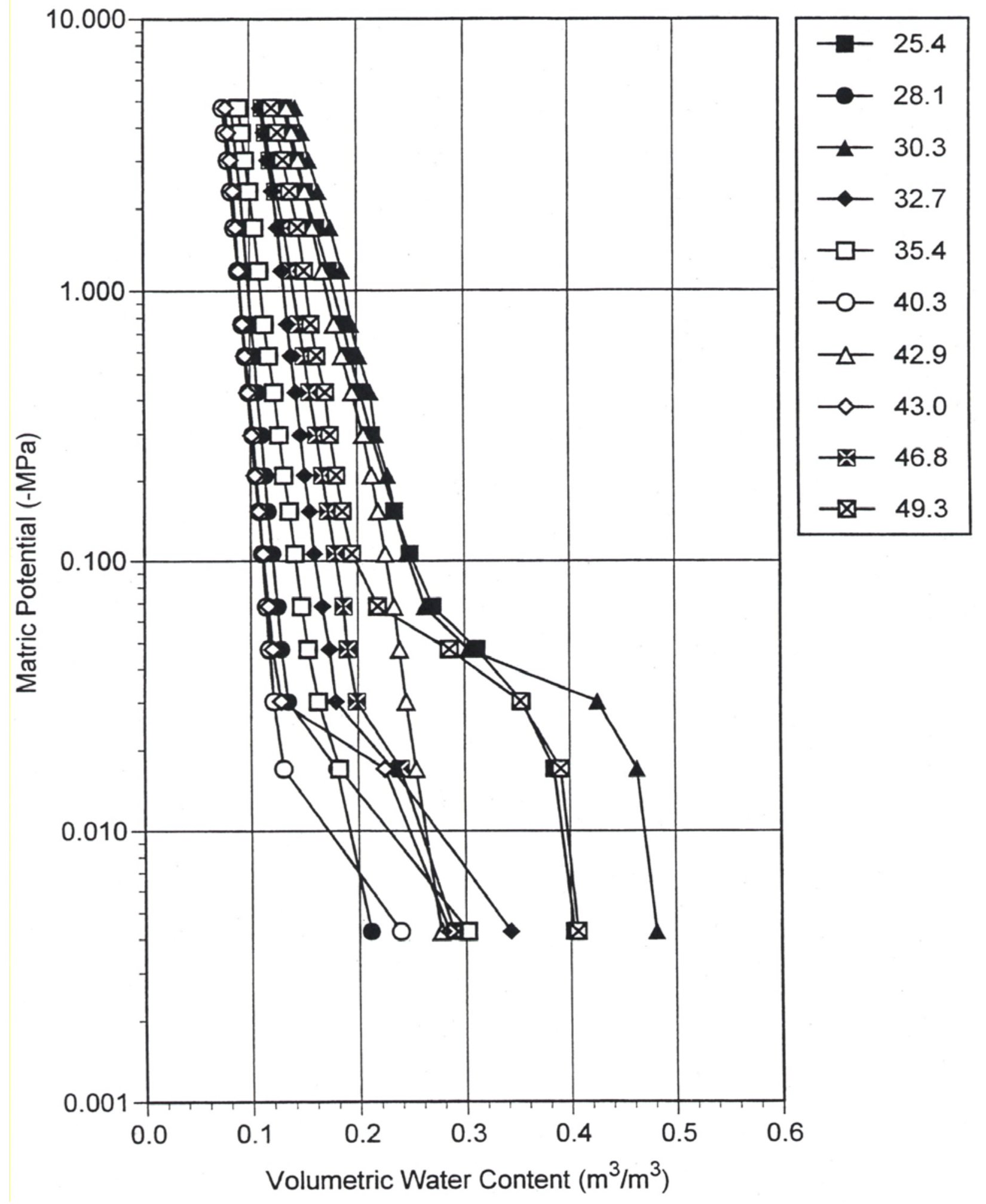

Figure 3-5

Water Retention Relations for U-3at-D1 samples at 10 Depths from 25.4 to 49.3 Meters

(Depths as indicated by symbols; matric potential given in MegaPascals; water content given in cubic meters per cubic meter) 


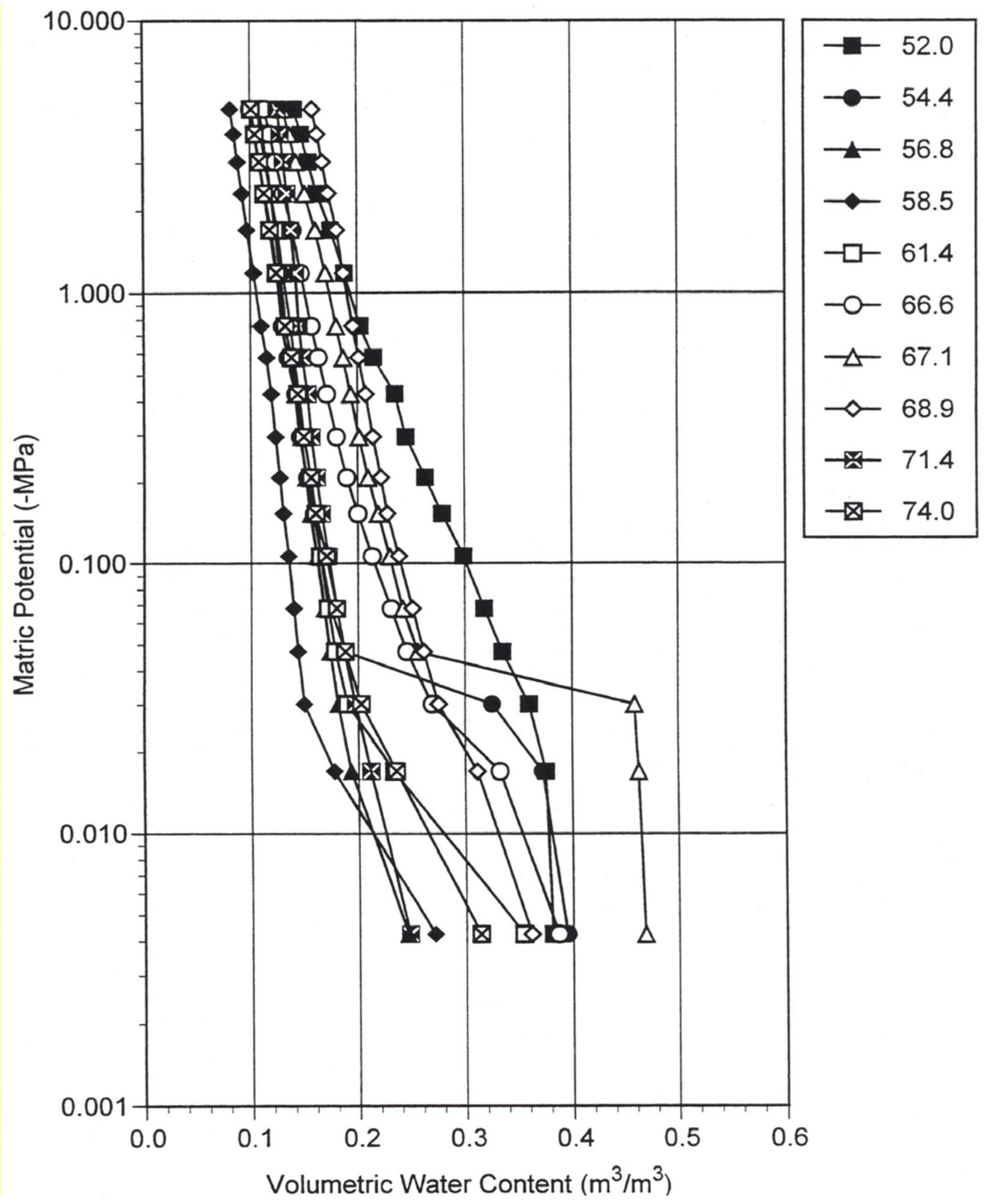

Figure 3-6

Water Retention Relations for U-3at-D1 Samples at 10 Depths from $\mathbf{5 2 . 0}$ to $\mathbf{7 4 . 0}$ Meters

(Depths as indicated by symbols; matric potential given in MegaPascals; water content given in cubic meters per cubic meter) 


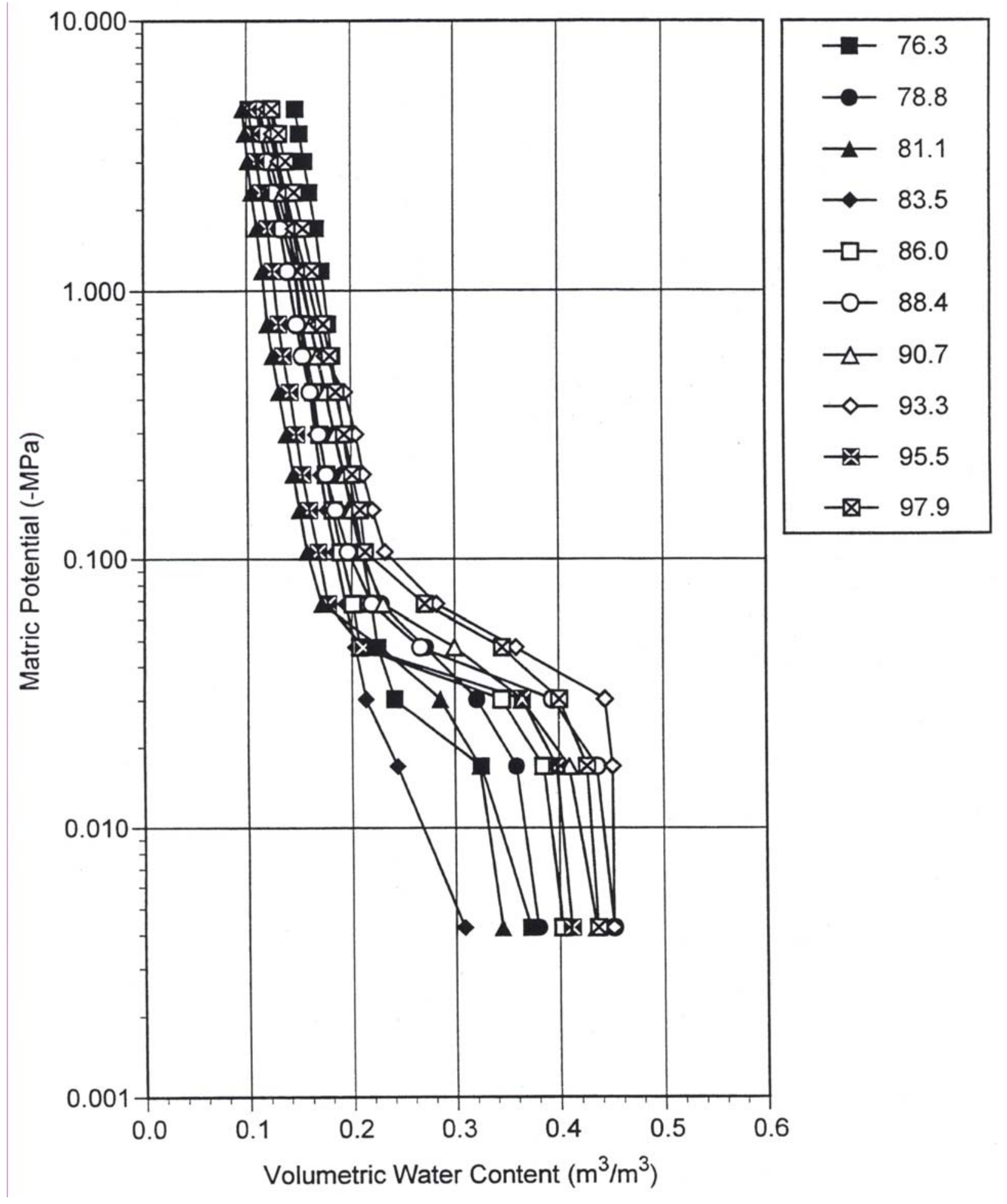

Figure 3-7

Water Retention Relations for U-3at-D1 Samples at 10 Depths from 76.3 to 97.9 Meters

(Depths as indicated by symbols; matric potential given in MegaPascals; water content given in cubic meters per cubic meter) 


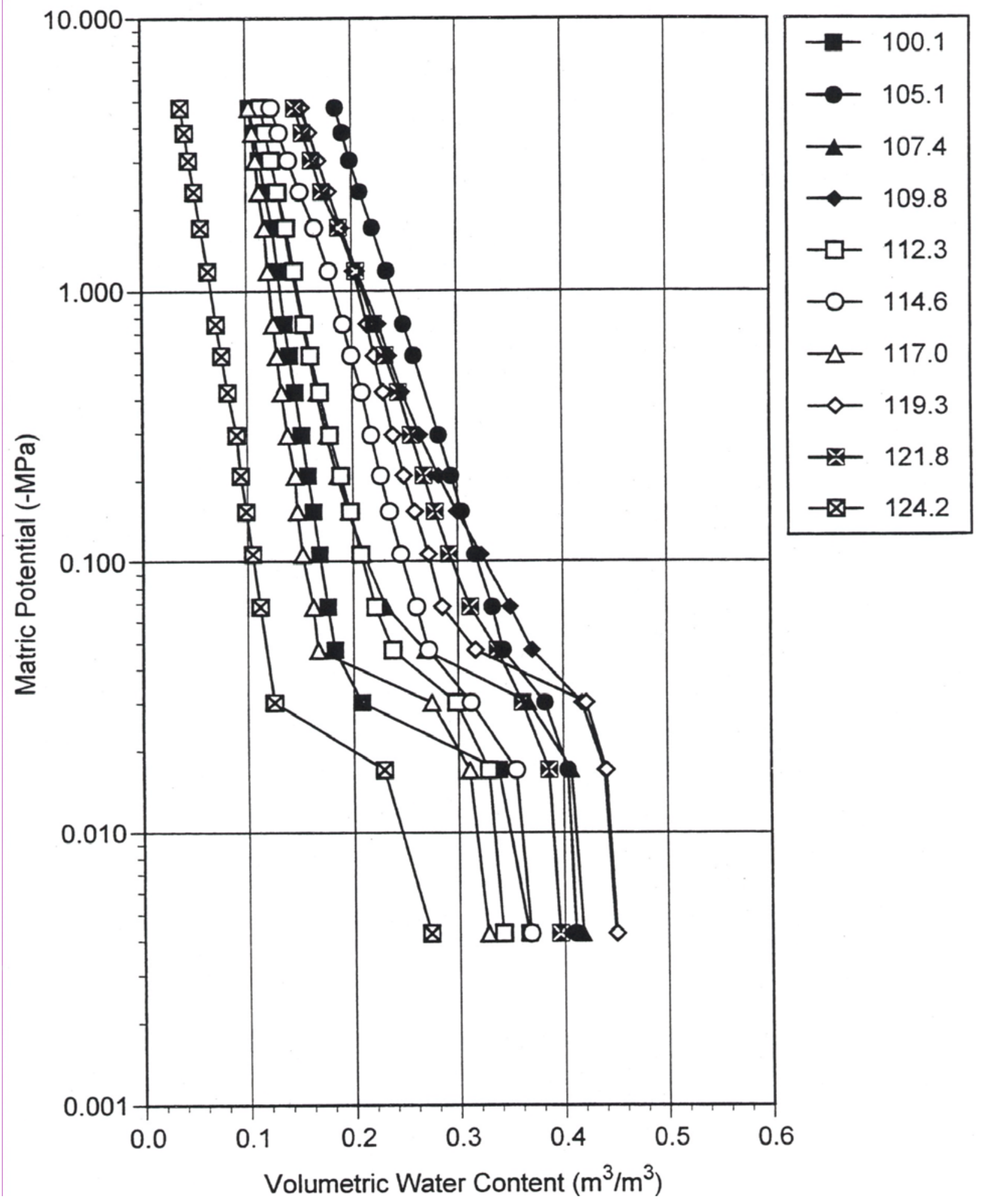

Figure 3-8

Water Retention Relations for U-3at-D1 Samples at 10 Depths from 100.1 to 124.2 Meters

(Depths as indicated by symbols; matric potential given in MegaPascals; water content given in cubic meters per cubic meter) 


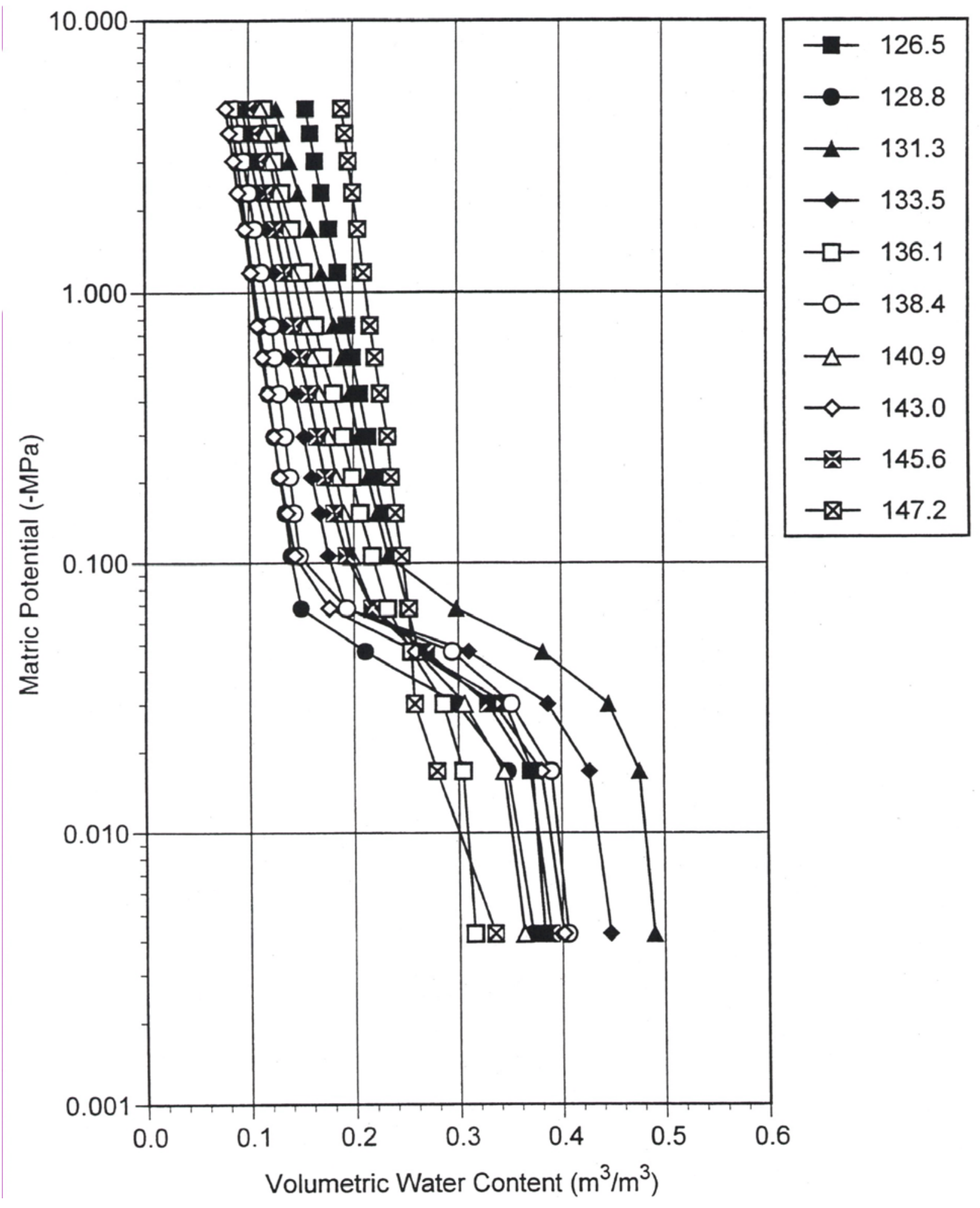

Figure 3-9

Water Retention Relations for U-3at-D1 Samples at 10 Depths from 126.5 to 147.2 Meters

(Depths as indicated by symbols; matric potential given in MegaPascals; water content given in cubic meters per cubic meter) 


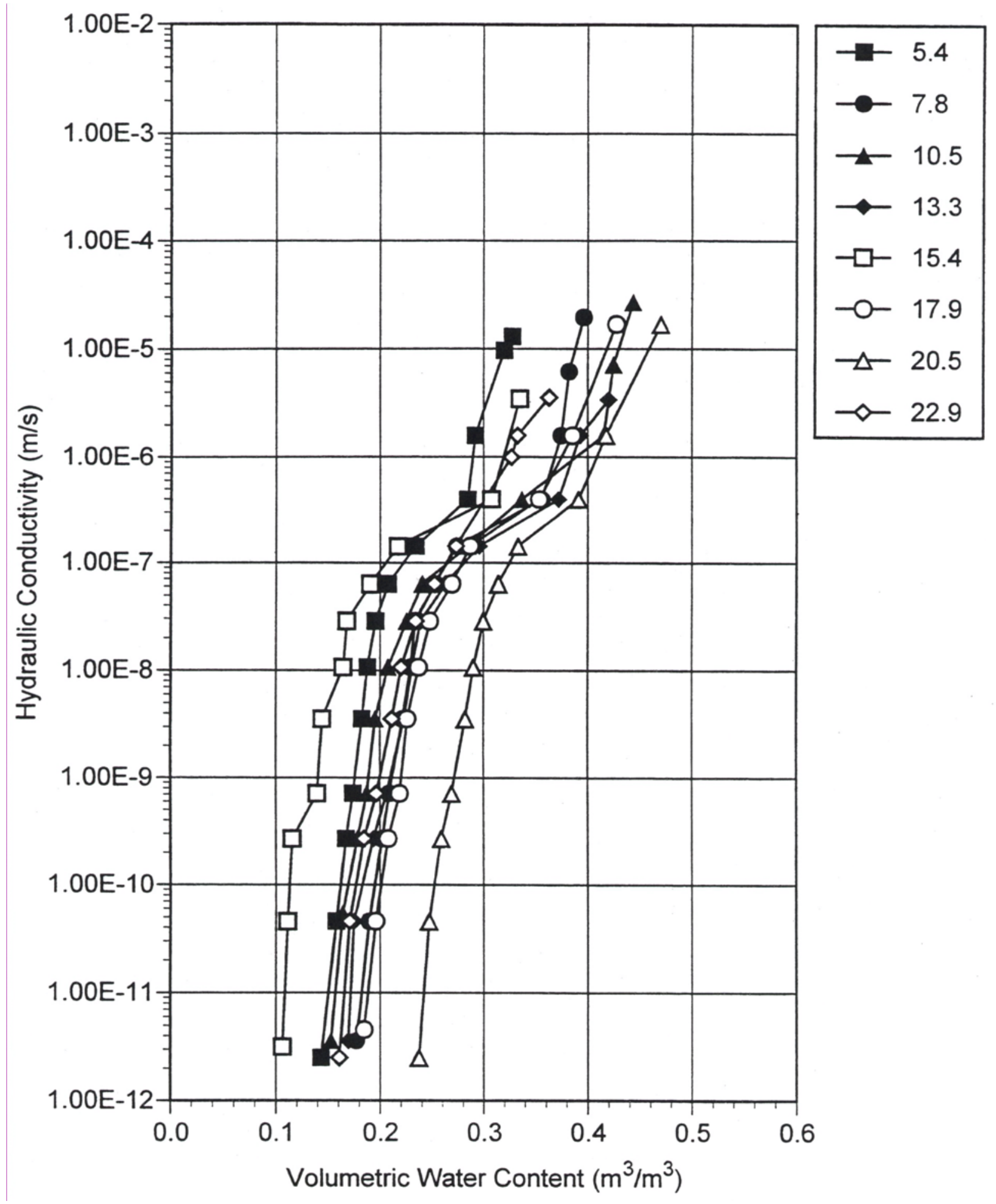

Figure 3-10

Hydraulic Conductivity I Water Content Relations for U-3at-D1 Samples at 8 Depths from 5.4 to 22.9 Meters

(Depths as indicated by symbols; hydraulic conductivity given in meters per second; water content given in cubic meters per cubic meter) 


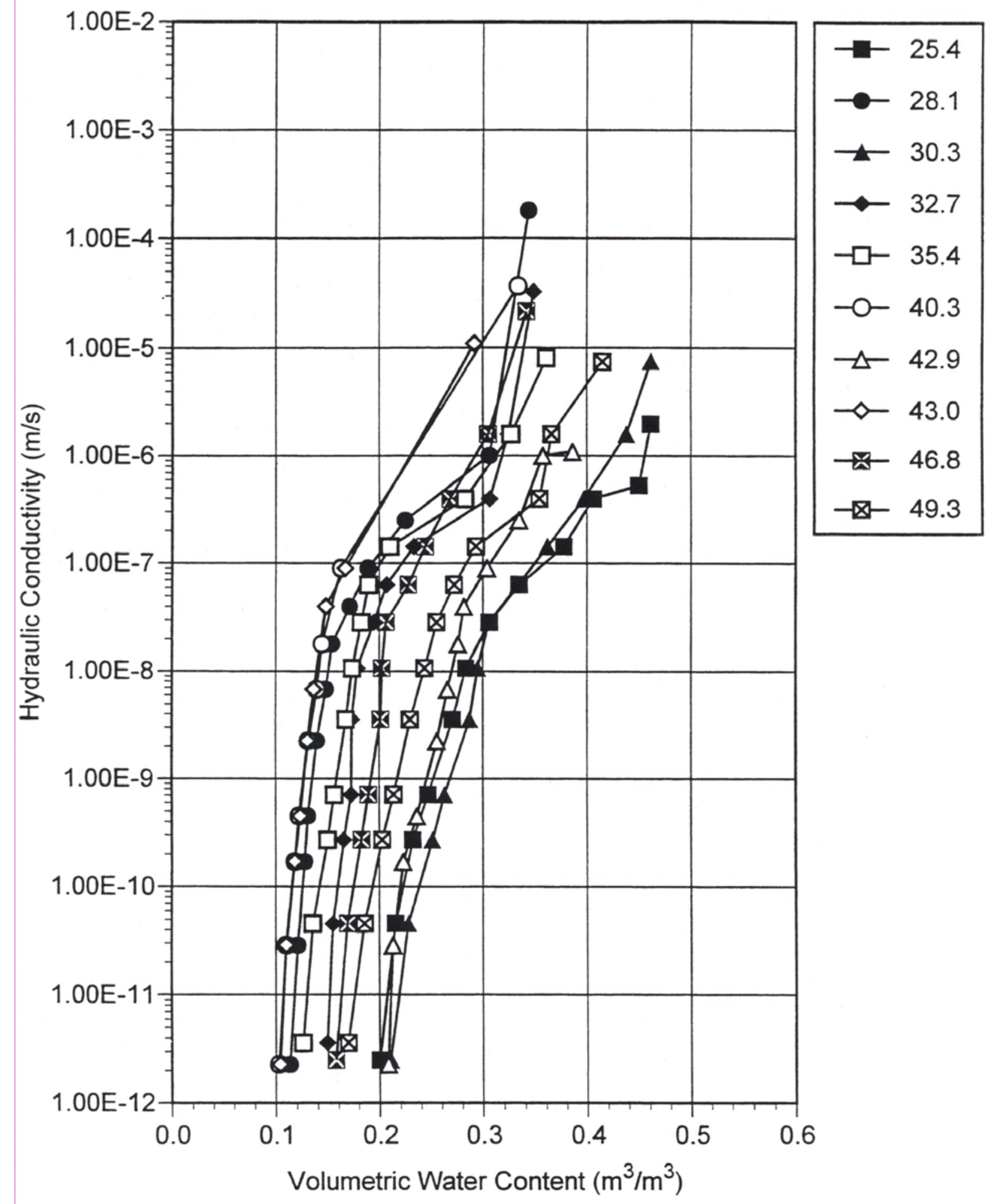

Figure 3-11

Hydraulic Conductivity I Water Content Relations for U-at-D1 Samples at 10 Depths from 25.4 to 49.3 Meters

(Depths as indicated by symbols; hydraulic conductivity given in meters per second; water content given in cubic meters per cubic meter) 


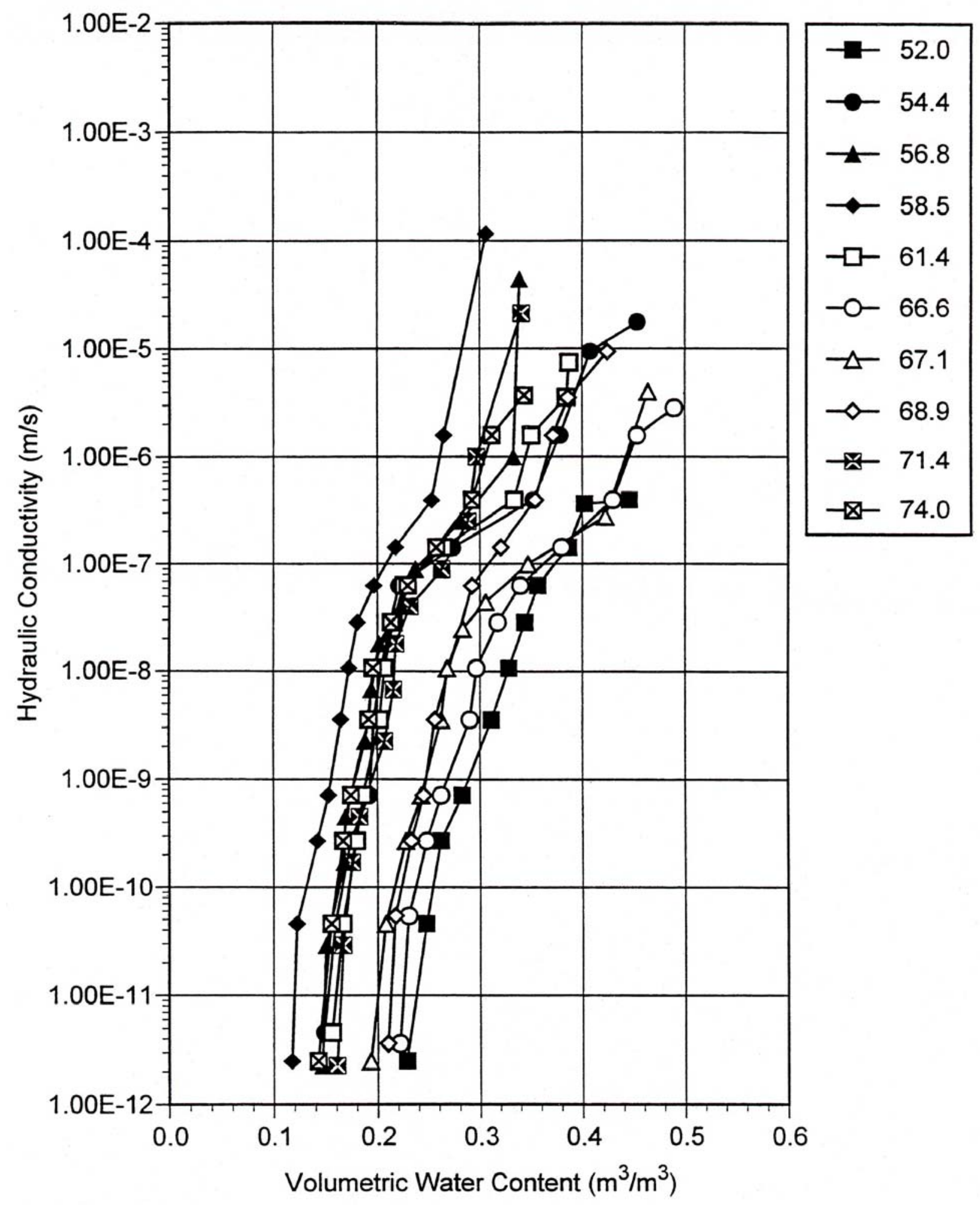

Figure 3-12

Hydraulic Conductivity I Water Content Relations for U-3at-D1 Samples at 10 Depths from 52.0 to 74.0 Meters

(Depths as indicated by symbols; hydraulic conductivity given in meters per second; water content given in cubic meters per cubic meter) 


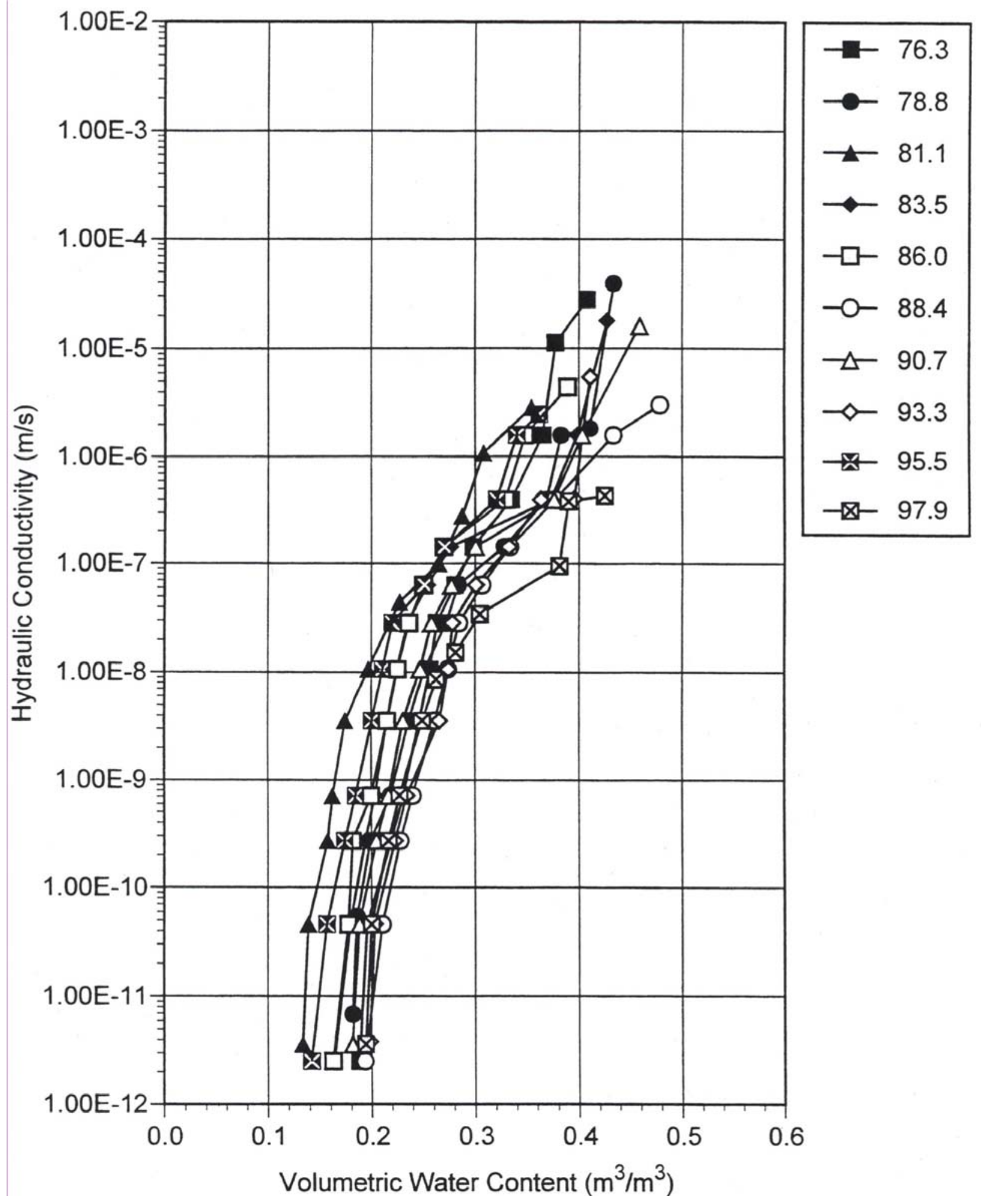

Figure 3-13

Hydraulic Conductivity I Water Content Relations for U-3at-D1 Samples at 10 Depths from 76.3 to 97.9 Meters

(Depths as indicated by symbols; hydraulic conductivity given in meters per second; water content given in cubic meters per cubic meter) 


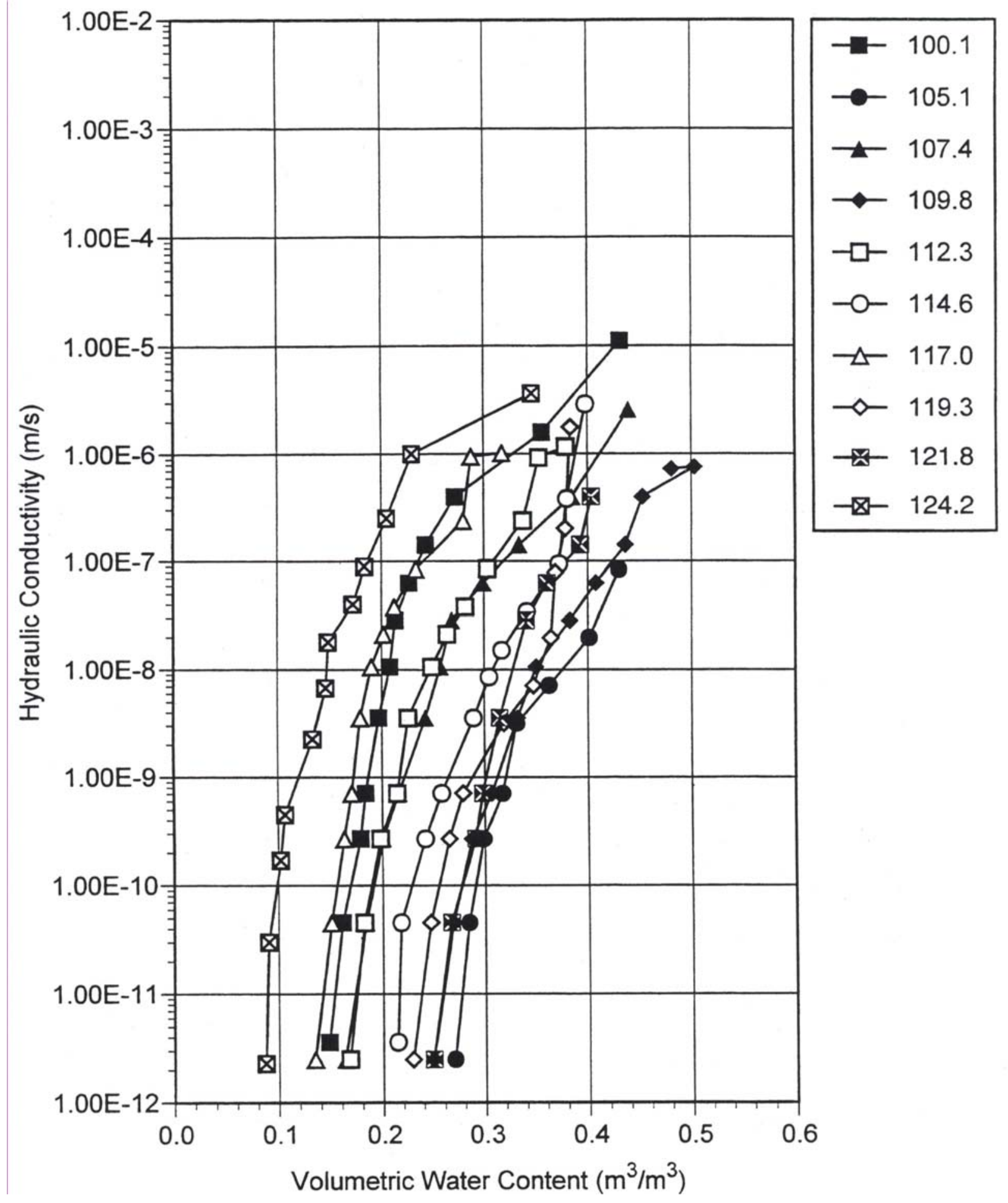

Figure 3-14

Hydraulic Conductivity I Water Content Relations for U-3at-D1 Samples at 10 Depths from $\mathbf{1 0 0 . 1}$ to $\mathbf{1 2 4 . 2}$ Meters

(Depths as indicated by symbols; hydraulic conductivity given in meters per second; water content given in cubic meters per cubic meter) 


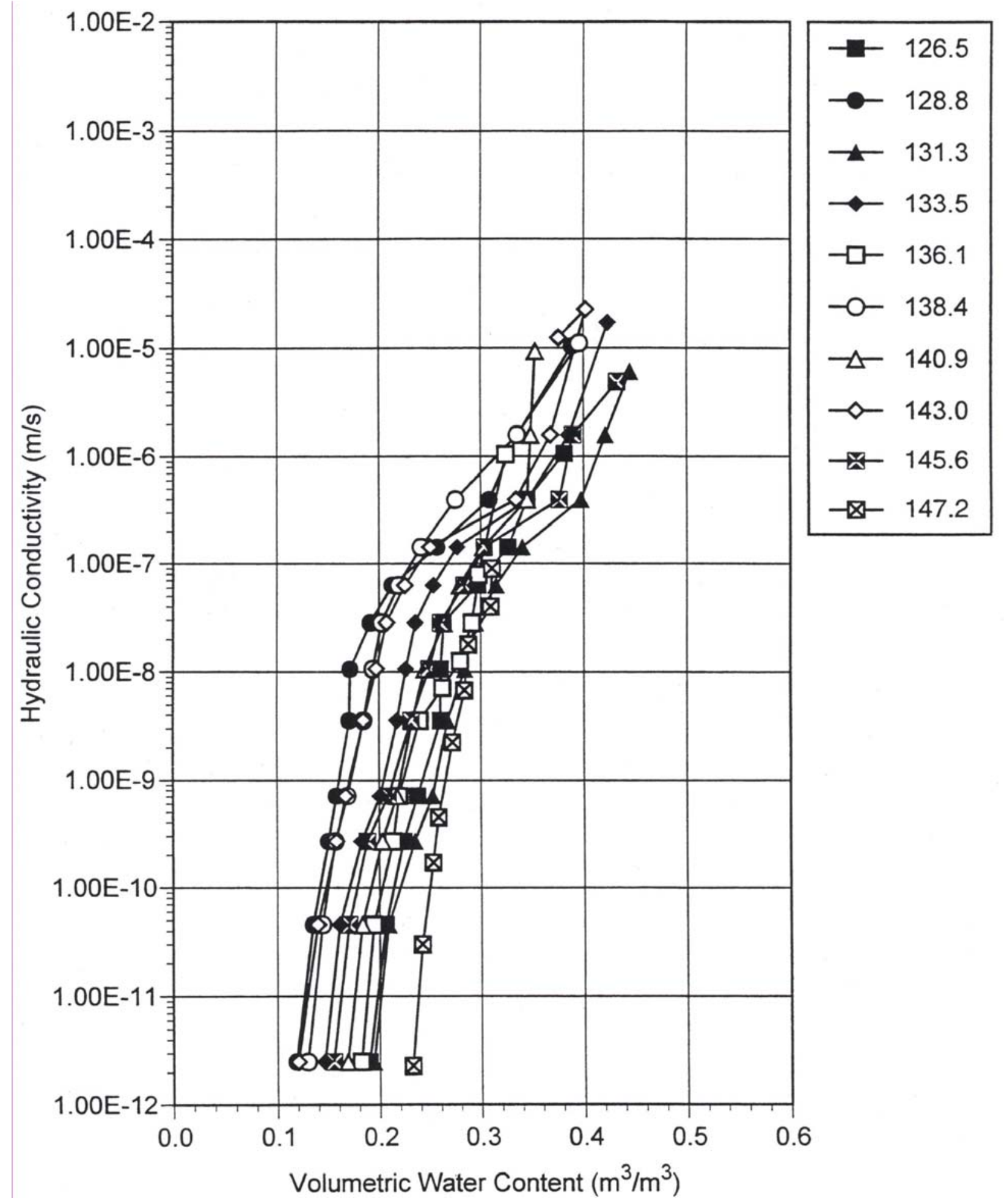

Figure 3-15

Hydraulic Conductivity I Water Content Relations for U-3at-D1 Samples at 10 Depths from 126.5 to 147.2 Meters

(Depths as indicated by symbols; hydraulic conductivity given in meters per second; water content given in cubic meters per cubic meter) 


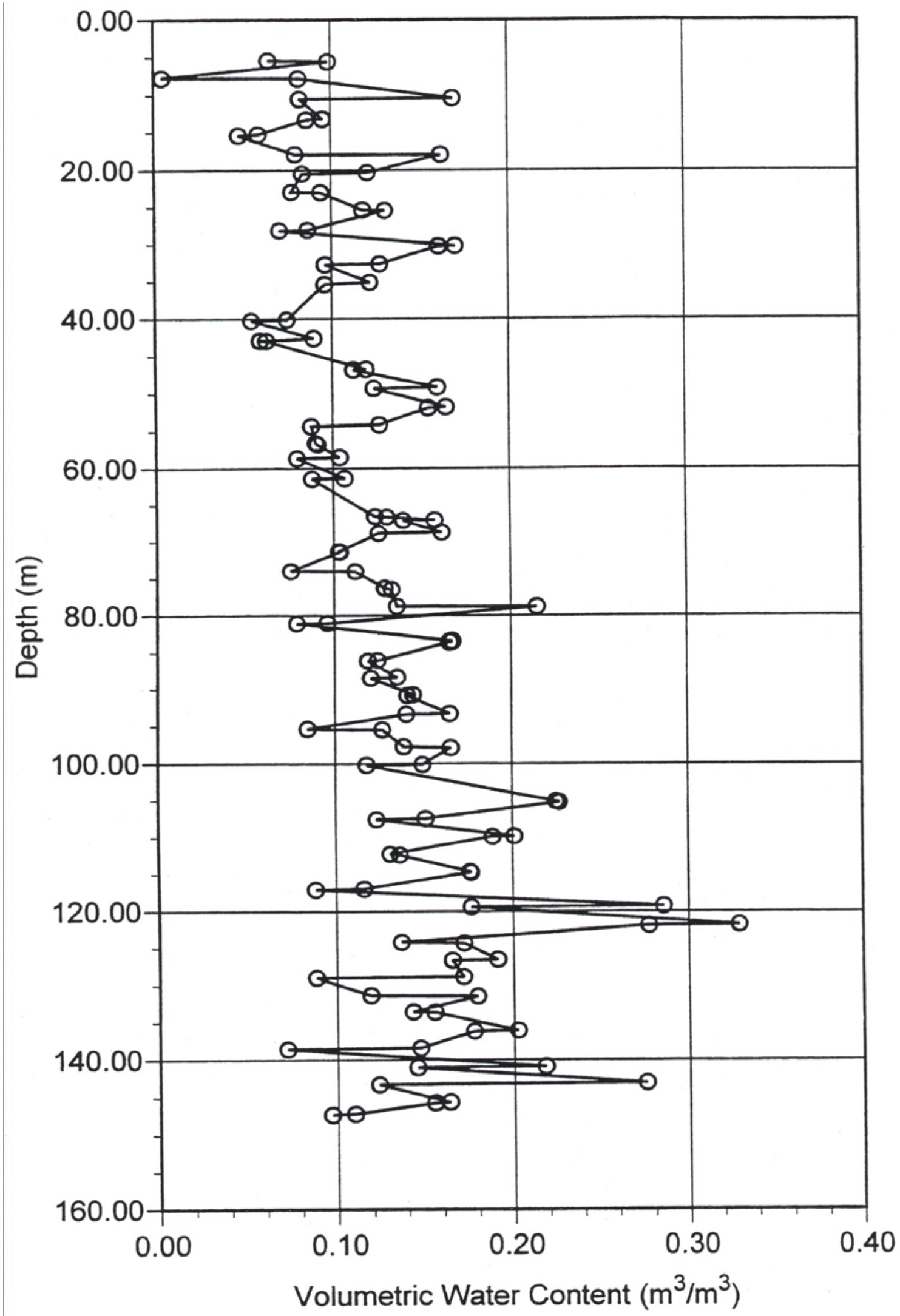

Figure 3-16

Volumetric Water Content versus Depth for U-3at-D1

(Water content given in cubic meters per cubic meter) 
The water potential values of samples taken from Borehole D1 range from -10.7 MegaPascals $(\mathrm{MPa})$ at $15.3 \mathrm{~m}(50.2 \mathrm{ft})$ to greater than $-0.40 \mathrm{MPa}$ at $78.9 \mathrm{~m}(259 \mathrm{ft})$ as shown in Figure 3-17. Although variable, water potential tends to increase with depth. The upper limit of water potential measurable with the water activity meter is $-0.40 \mathrm{MPa}$ (Gee et al., 1992). Below a depth of $120.1 \mathrm{~m}$ (394 ft), water potential values are consistently greater than this limit.

\subsection{Environmental Tracers at Borehole U-3at-D1}

\subsubsection{Stable Isotopes}

Concentrations of stable isotopes of oxygen (oxygen-18 $\left[{ }^{18} \mathrm{O}\right]$ ) and of hydrogen (deuterium [D]) in water provide indications of past and current water fluxes in the vadose zone. Concentrations of deuterium and ${ }^{18} \mathrm{O}$ in the pore water of samples obtained from Borehole D1 are shown in Figures 3-18 and 3-19. Concentrations are reported in standard delta ( $\delta$ ) notation in reference to standard mean ocean water (SMOW). Reproducibility of the values is \pm 1 part per thousand (\%). In general, enrichment in the heavy isotopes (less negative values) is shown near the land surface. This enrichment in the upper portion of the profile is caused by evaporation.

A comparison of stable isotope concentrations in pore water from Borehole D1 samples and precipitation is shown in Figure 3-20. The local meteoric water line (LMWL) represents the ratio of stable isotopes in precipitation and has been described by Tyler et al. (1996) for the NTS as:

$$
\delta \mathrm{D}=6.26 \cdot \delta^{18} \mathrm{O}-15.3
$$

Isotopic compositions of the majority of Borehole D1 samples fall below the LMWL. This deviation from the LMWL is typical of systems with significant evaporation.

Figures 3-18 and 3-19 show that below $29.9 \mathrm{~m}$ (98 ft), isotope concentrations vary little and display no trend with depth. Average concentrations are $-14.2 \%$ for $\delta^{18} \mathrm{O}$, and $-111 \%$ for $\delta \mathrm{D}$. Weighted mean isotope concentrations for winter precipitation at the NTS have been estimated to be $-12.5 \%$ and $-93 \%$ or $\delta^{18} \mathrm{O}$ and $\delta \mathrm{D}$, respectively (Tyler et al., 1996). Winter concentrations represent precipitation under cooler temperatures. Comparing the winter mean concentrations with the average concentrations of the profiles in Figures 3-18 and 3-19 shows that isotopic compositions of samples from Borehole D1 were more depleted than weighted mean values for winter precipitation. These results indicate that the pore water found in the samples from the collapse zone below $30 \mathrm{~m}$ (98 ft) must have infiltrated under cooler, past climate conditions.

\subsubsection{Chloride and Calcium Carbonate Profiles}

The soil chloride profile shown for Borehole D1 in Figure 3-21 indicates an accumulation of

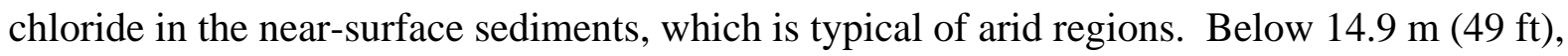

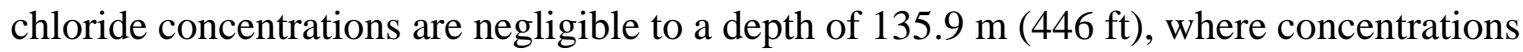




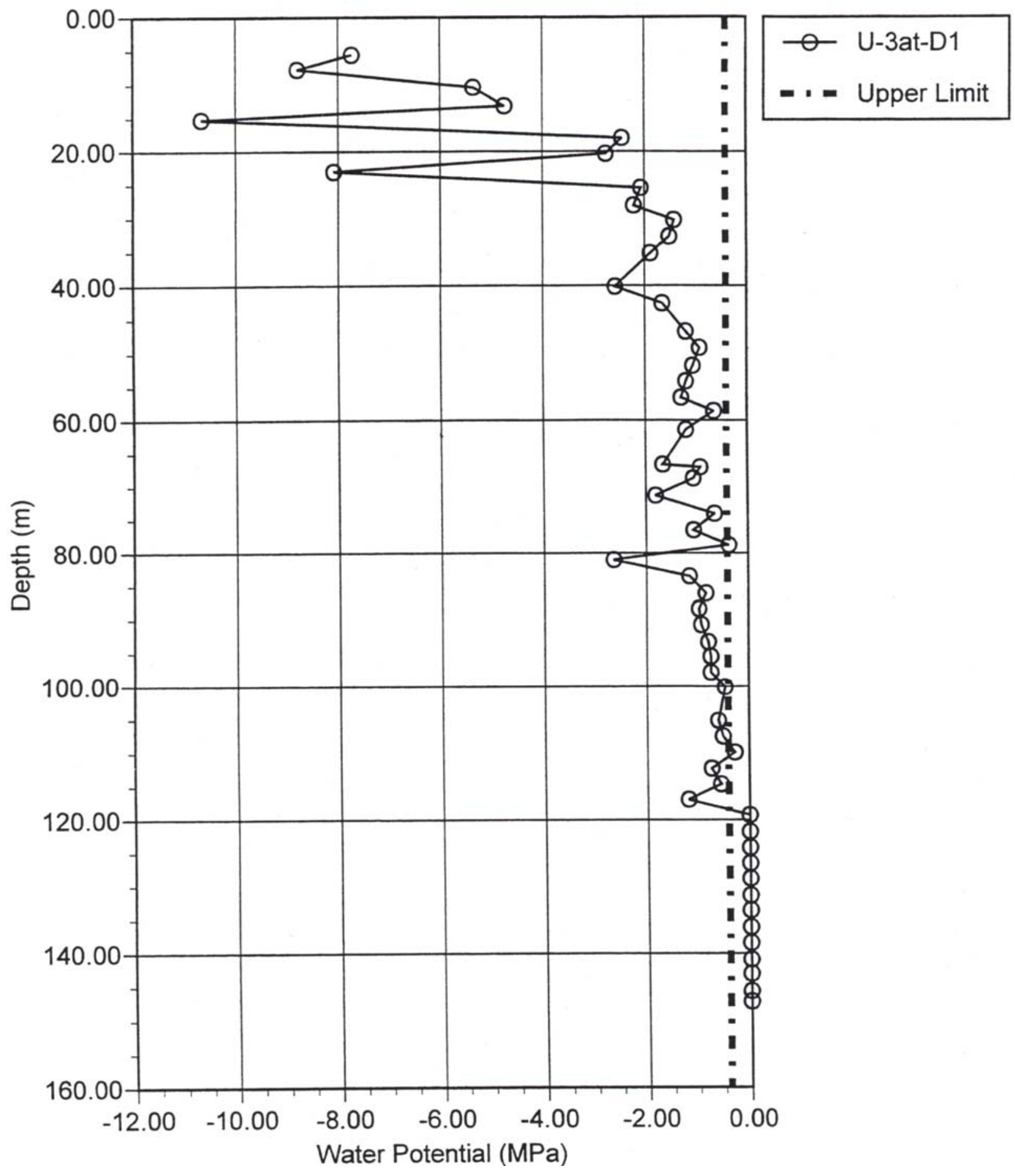

Figure 3-17

Water Potential versus Depth for U-3at-D1

(The dashed line at -0.4 MegaPascals indicates the upper limit of water potential measurable with the water activity meter) 


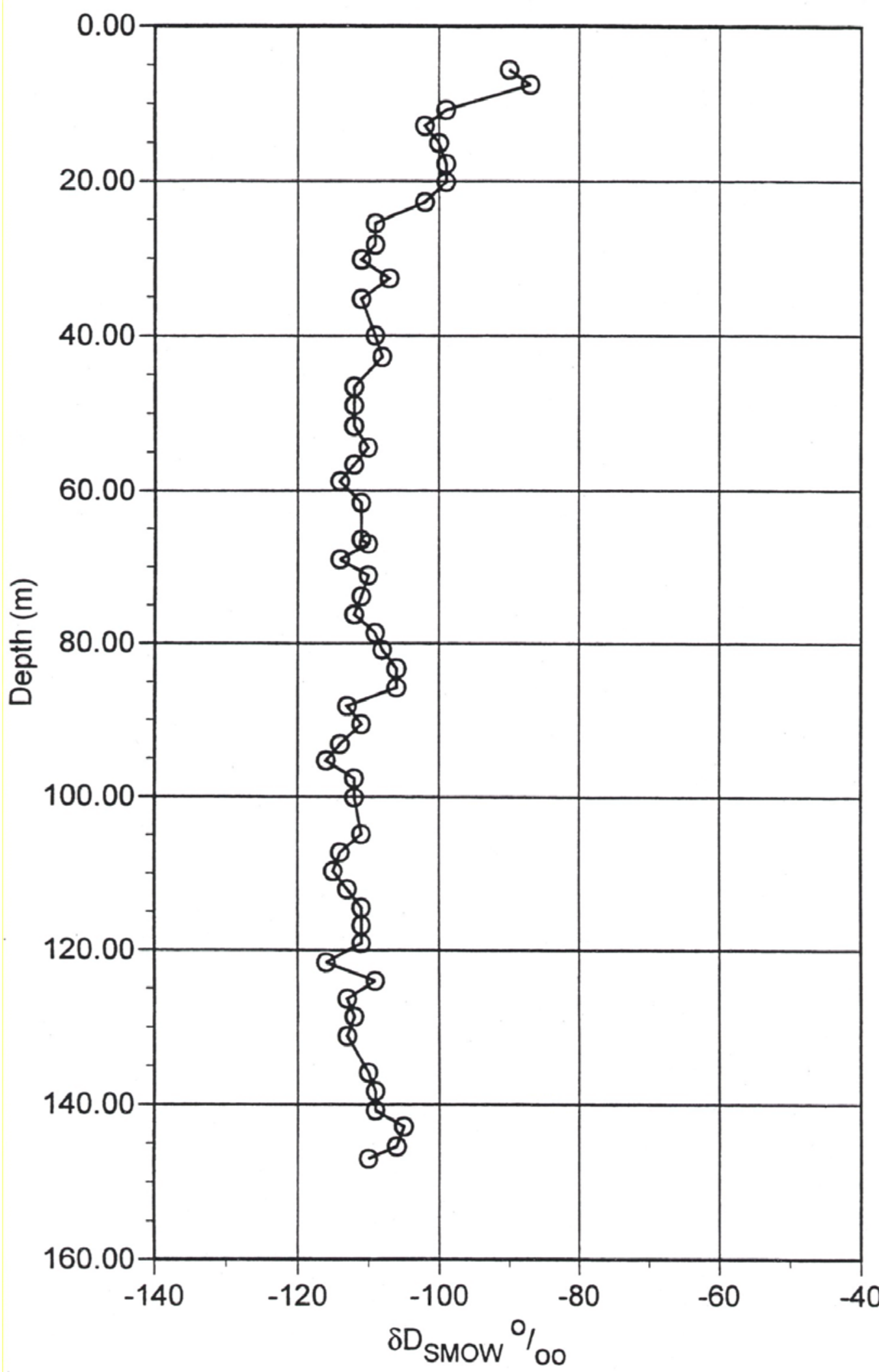

Figure 3-18

Deuterium Concentrations in Pore Water from U-3at-D1 versus Depth

(Expressed in standard delta notation relative to standard mean ocean water in parts per thousand) 


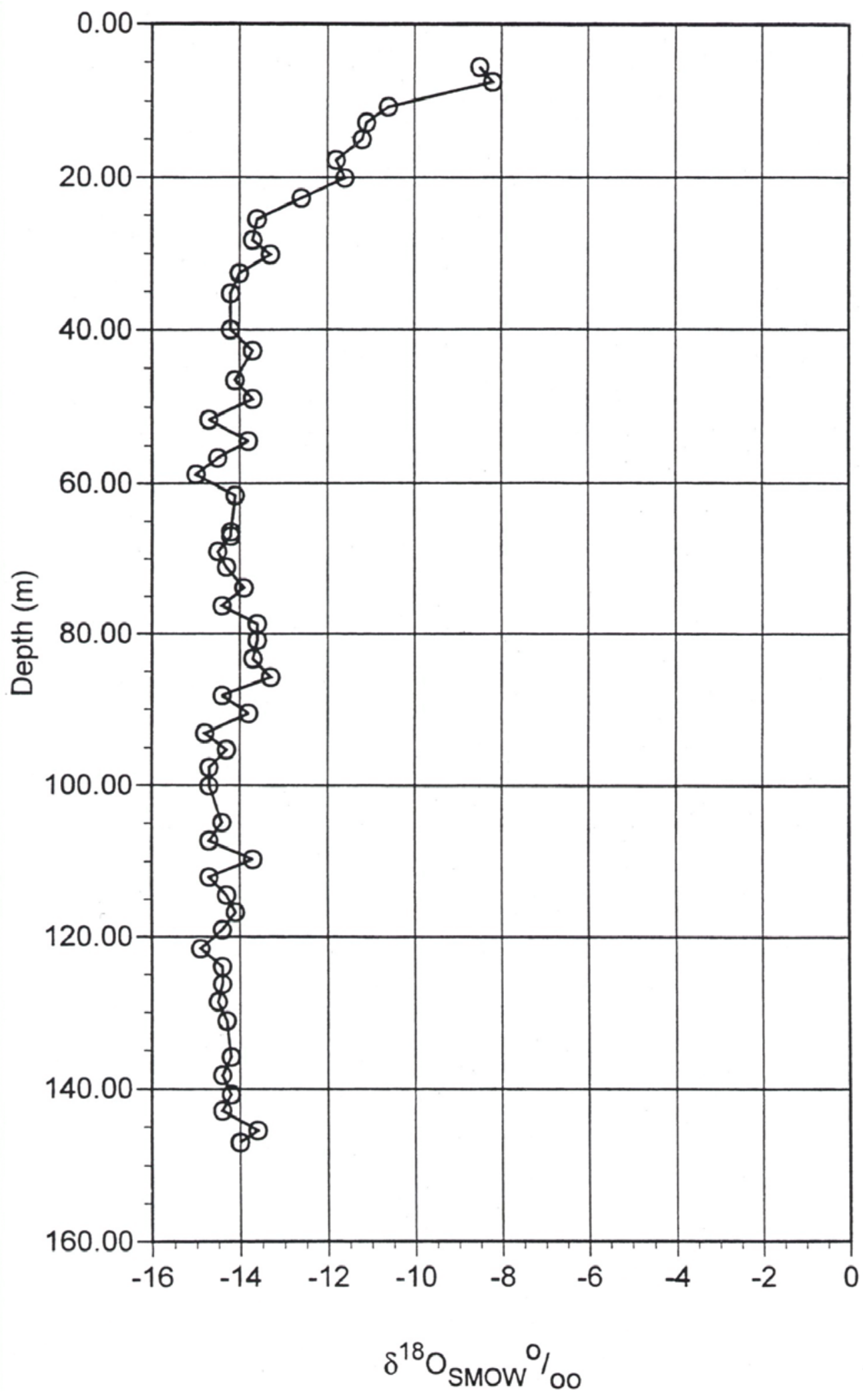

Figure 3-19

Oxygen-18 Concentrations in Pore Water from U-3at-D1 versus Depth

(Expressed in standard delta notation relative to standard mean ocean water in parts per thousand) 


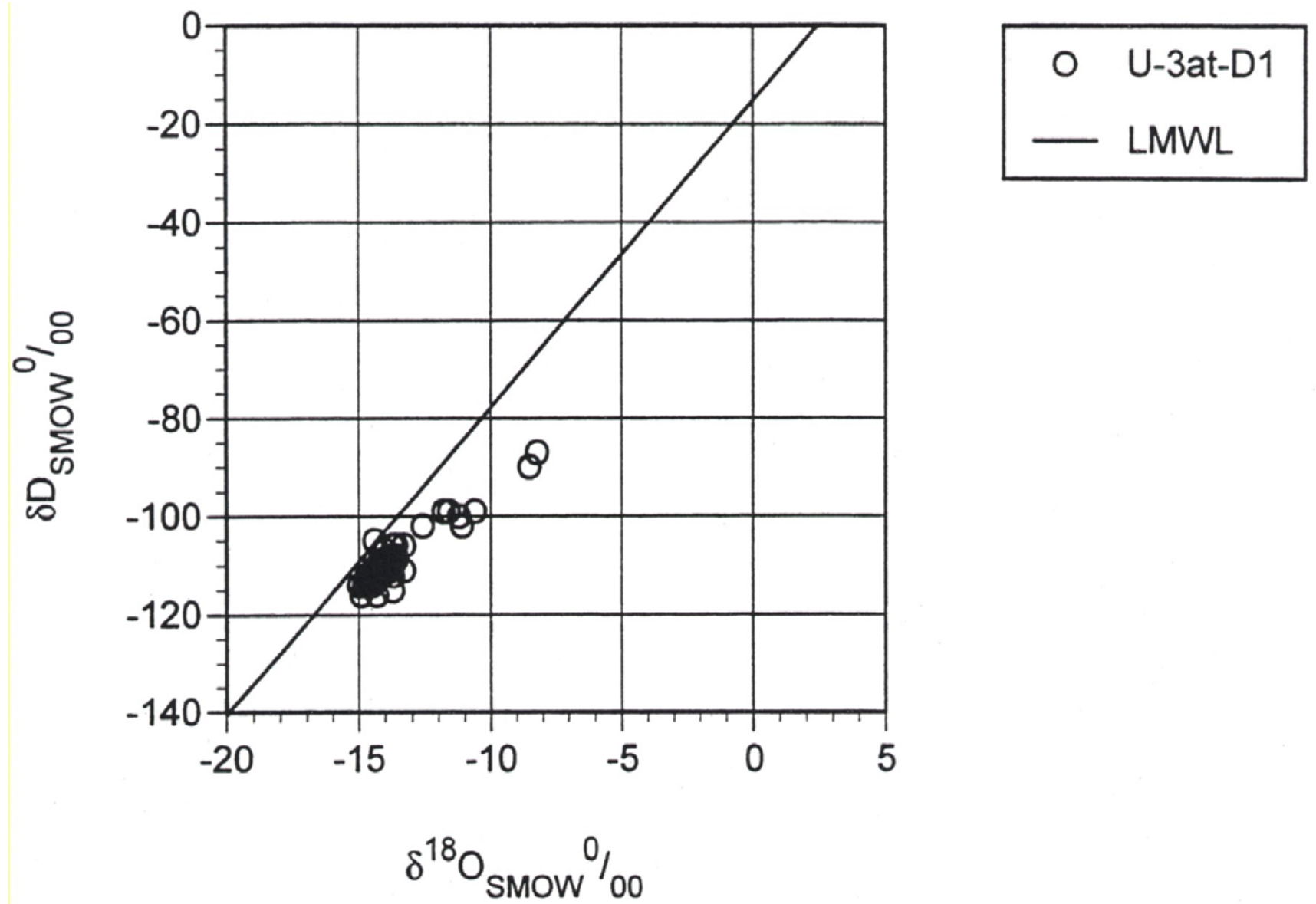

Figure 3-20

Stable Isotope Concentrations in Pore Water from U-3at-D1 and Local Meteoric Water Line (LMWL)

(Expressed in standard delta notation relative to standard mean ocean water in parts per thousand) 


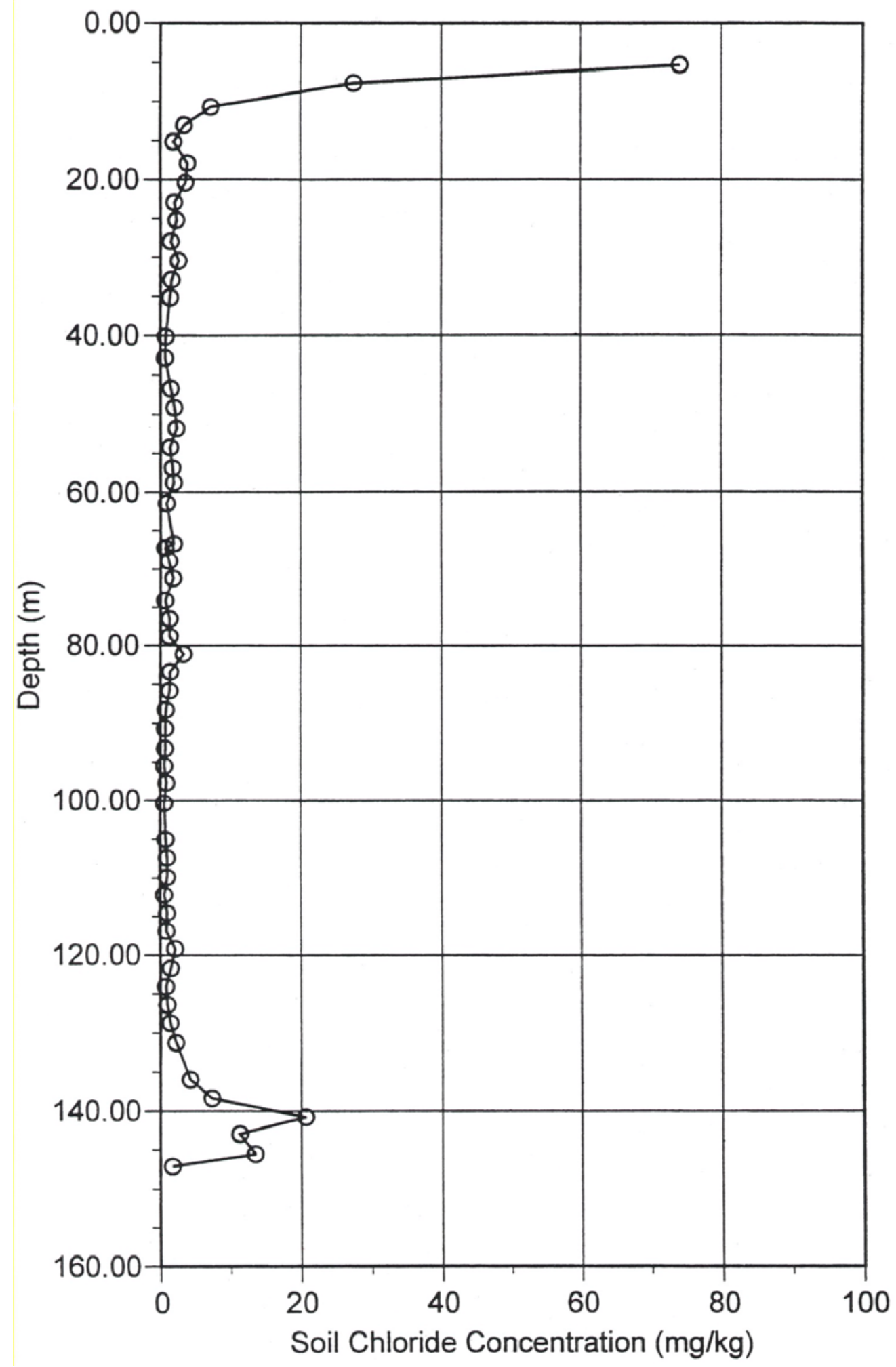

Figure 3-21

Soil Chloride Concentrations versus Depth for U-3at-D1 (In milligrams per kilogram) 
increase and reach a maximum of 20.7 milligrams/kilogram at $140.8 \mathrm{~m}$ (462 ft). From this

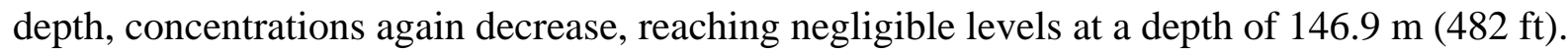
Three samples (from depths 140.8, 143.0, and $145.4 \mathrm{~m}$ [462, 469, and $477 \mathrm{ft}$ ]) have elevated concentrations of chloride. An inspection of these and adjacent samples under a binocular microscope and in hand sample found no obvious lithologic, diagenetic, or pedogenic explanation for the differences in chloride.

Calcium carbonate equivalent for Borehole D1 is shown with depth in Figure 3-22. Calcium carbonate equivalent concentrations at 30.5 and $119.2 \mathrm{~m} \mathrm{(100} \mathrm{and} 391 \mathrm{ft}$ ) below the surface are approximately 12 percent, substantially greater than concentrations from most other samples analyzed. An inspection of these and adjacent samples, using a binocular microscope and in hand sample, found no significant difference in clast lithology, but the matrix of the two samples in question was cemented by calcium carbonate and contained weathered fragments of caliche.

\subsubsection{Tritium Profiles}

A plot of tritium concentration versus vertical depth for the Borehole D1 samples, is shown in Figure 3-23. Concentrations are below the detection limits (226 to 312 picoCuries per liter [pCi/L]) from the surface to a depth of $119 \mathrm{~m}$ (390 ft). Below this depth, concentrations

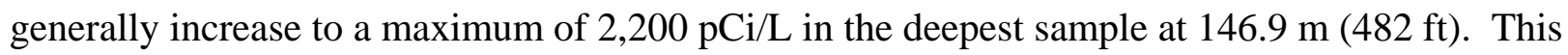
tritium most likely originated as a product of the nuclear test.

\subsection{Results of Verification Testing at Borehole U-3at-D2}

The purpose of drilling and sampling Borehole D2 was to confirm that core samples taken from Borehole D1 over the interval of 50.9 to $71.6 \mathrm{~m}$ (167 to $235 \mathrm{ft}$ ) had not been altered by the addition of fluids during drilling. Thirteen samples were taken from Borehole D2 over the interval 47.5 to $78.3 \mathrm{~m}$ (156 to $257 \mathrm{ft}$ ) and tested for the same characteristics and properties as samples from Borehole D1. These results are shown in Figures 3-24 to 3-36.

Particle density values (Figure 3-24) are similar to those observed for the same depth interval in Borehole D1. Particle size distributions shown in Figure 3-25 are similar, except for a high-silt zone at $63.7 \mathrm{~m}$ (209 ft), which was not seen in Borehole D1. Bulk density; water-retention relations; hydraulic conductivity water-content relations; and chloride, carbonate, and tritium concentrations (Figures 3-26 to 3-31) are similar to those observed in the same depth interval in Borehole D1.

The variation of volumetric water content with depth for Borehole D2 is shown in Figure 3-32. Volumetric water content values over similar depths from Borehole D1 are also plotted for comparison. Volumetric water content in the vertical depth interval 46.9 to $78.9 \mathrm{~m}$ (154 to $259 \mathrm{ft}$ ) in Borehole D1 ranges from 0.076 to $0.215 \mathrm{~m}^{3} / \mathrm{m}^{3}$, with a mean of $0.123 \mathrm{~m}^{3} / \mathrm{m}^{3}$. In Borehole D2, volumetric water content in the depth interval 47.9 to $78.3 \mathrm{~m}$ (157 to $257 \mathrm{ft}$ ) is more variable, ranging from 0.067 to $0.254 \mathrm{~m}^{3} / \mathrm{m}^{3}$, with a mean of $0.145 \mathrm{~m}^{3} / \mathrm{m}^{3}$. These differences in the range and mean are small enough to be attributed to spatial variability. 


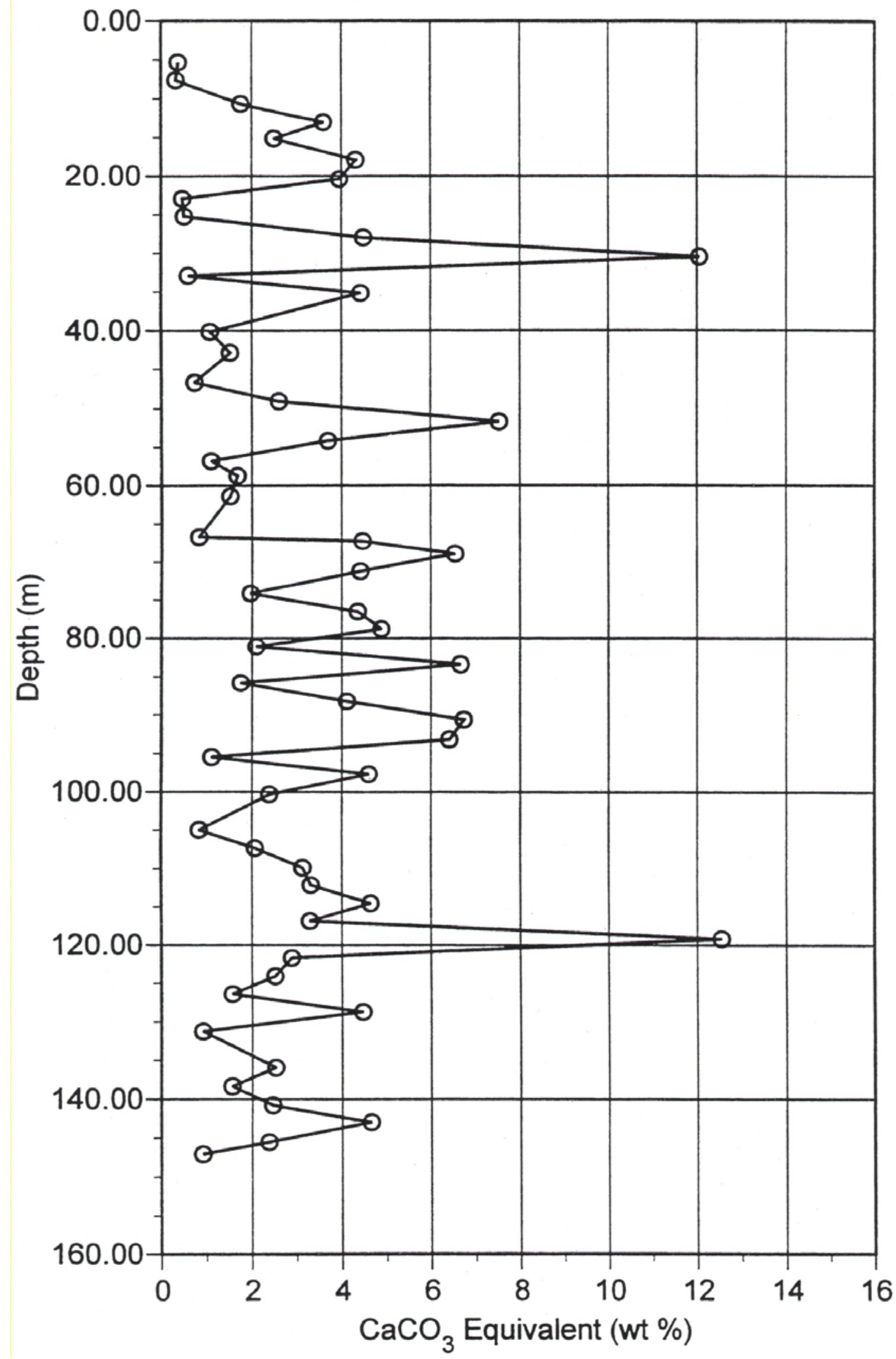

Figure 3-22

Calcium Carbonate Equivalent within the Fine-Earth Fraction (less than 2 millimeters) versus Depth for U-3at-D1

(Oven-dry weight percent) 


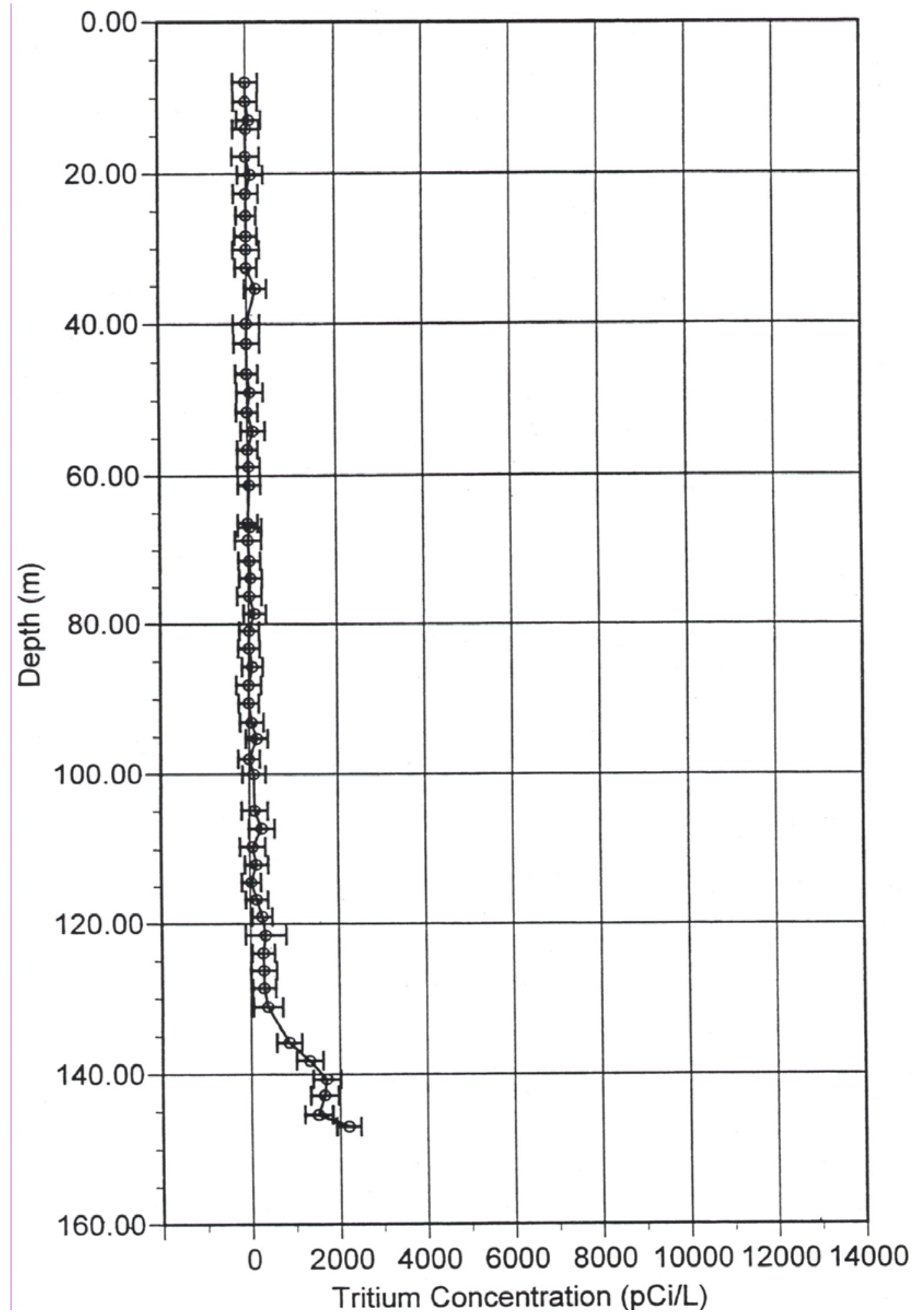

Figure 3-23

Tritium Concentrations versus Depth for U-3at-D1

(Bars indicate counting error) 


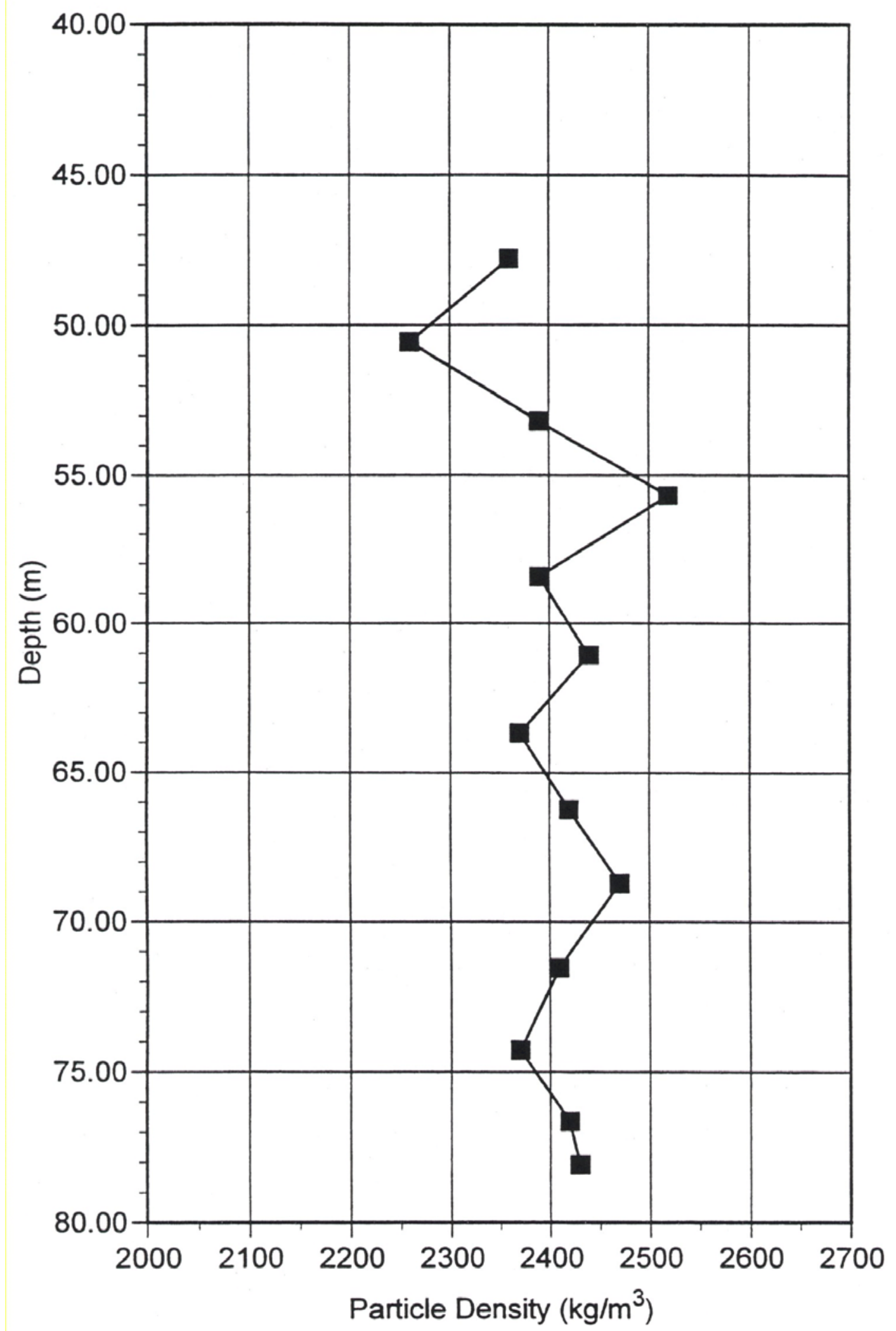

Figure 3-24

Particle Density versus Depth for U-3at-D2

(In kilograms per cubic meter) 


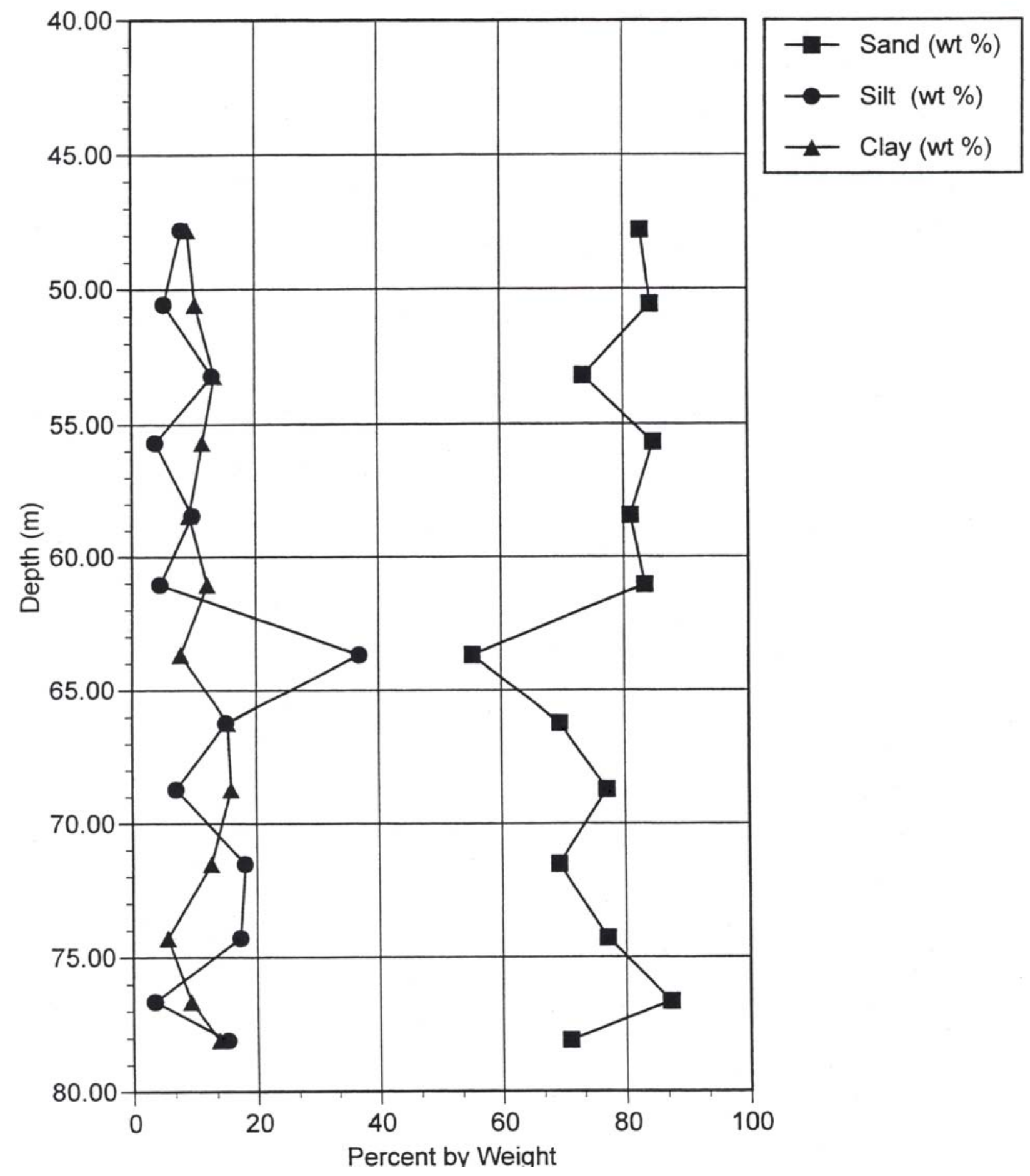

Figure 3-25

Sand, Silt, and Clay Fractions versus Depth for U-3at-D2 


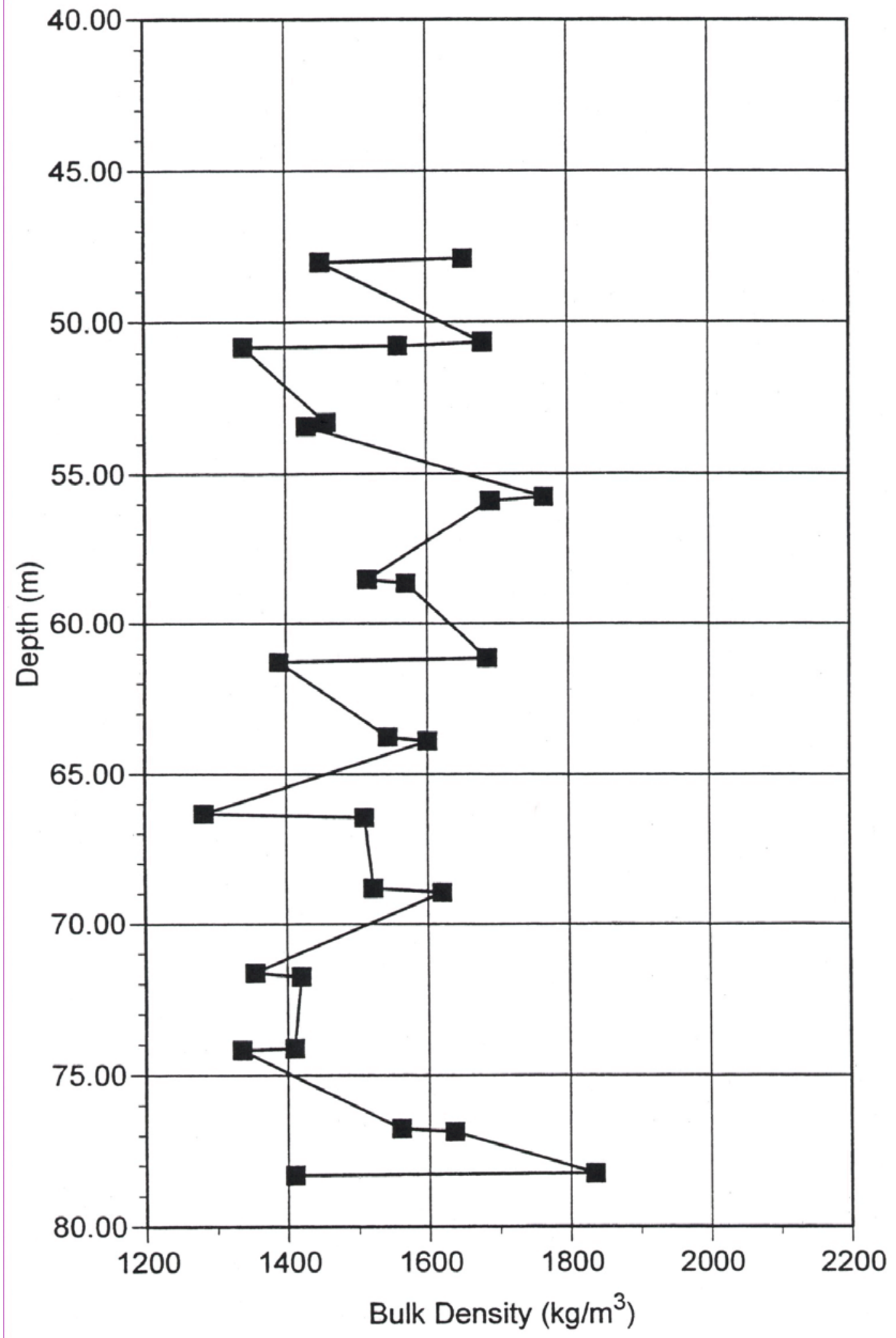

Figure 3-26

Dry Bulk Density versus Depth for U-3at-D2

(In kilograms per cubic meter) 


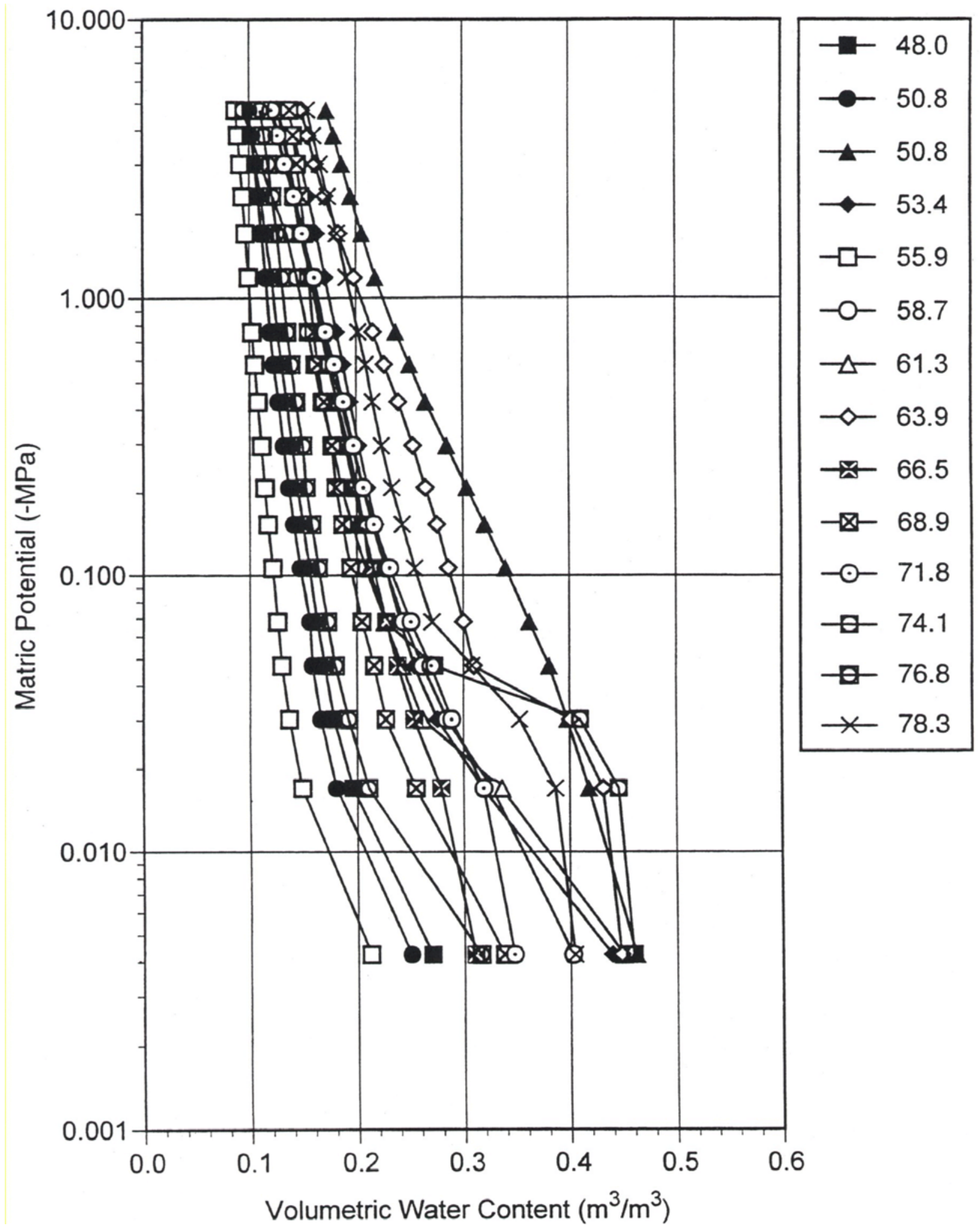

Figure 3-27

Water Retention Relations for U-3at-D2 Samples at 14 Depths from 48.0 to 78.3 Meters

(Depths as indicated by symbols; matric potential given in MegaPascals; water content given in cubic meters per cubic meter) 


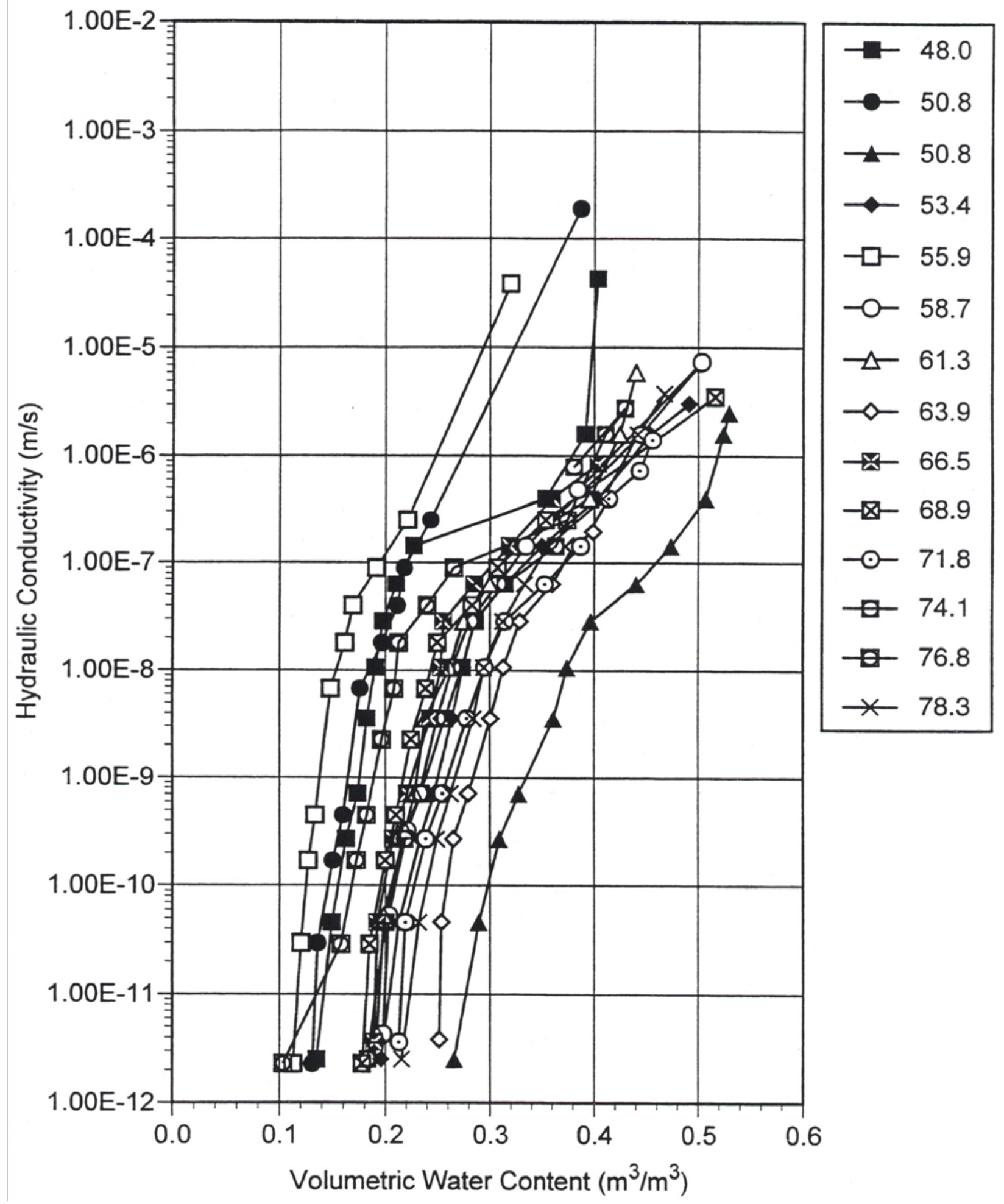

Figure 3-28

Hydraulic Conductivity I Water Content Relations for U-3at-D2 Samples at 14 Depths from 48.0 to 78.3 Meters

(Depths as indicated by symbols; hydraulic conductivity given in meters per second; water content given in cubic meters per cubic meter) 


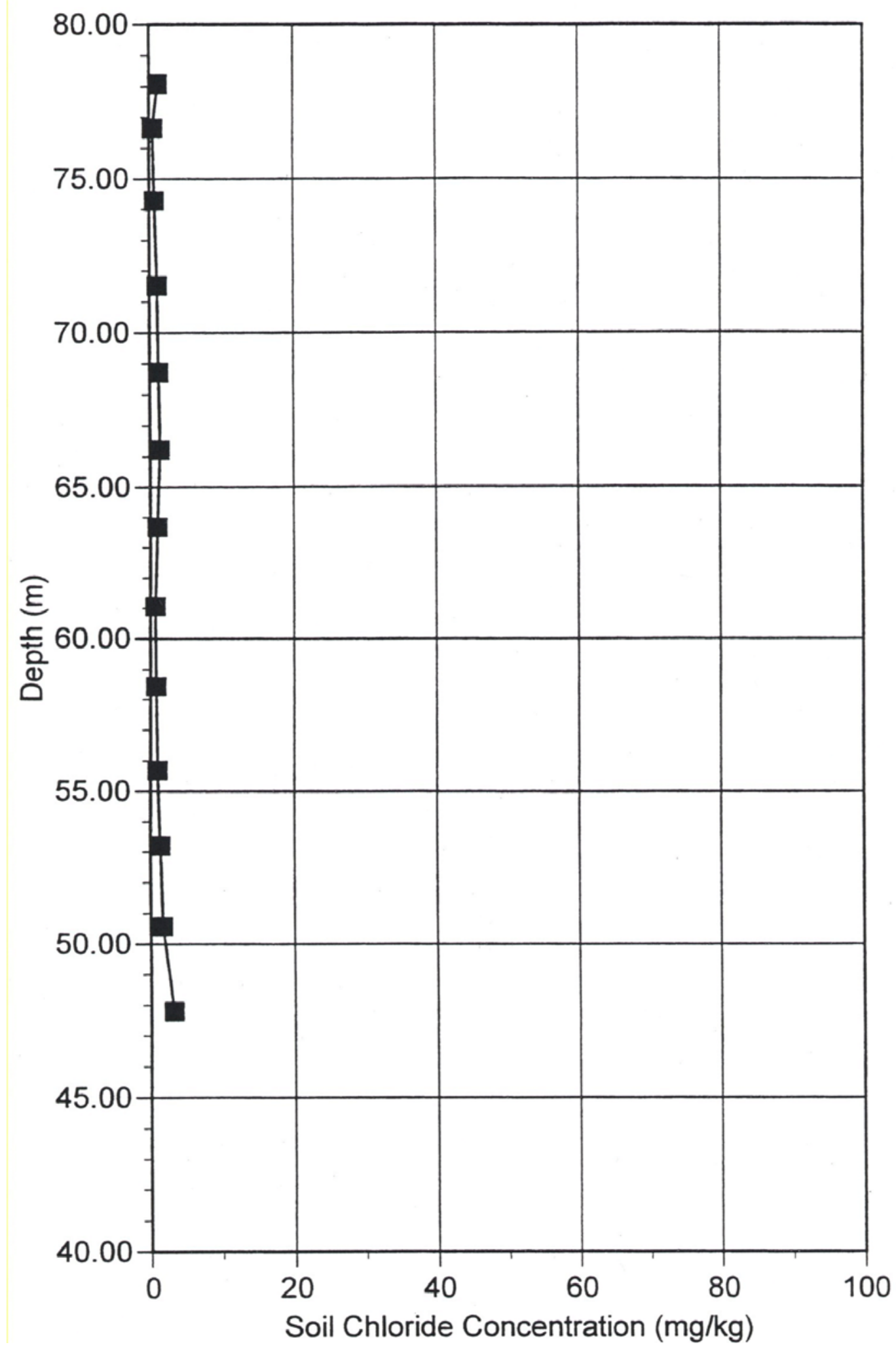

Figure 3-29

Soil Chloride Concentration versus Depth for U-3at-D2

(In milligrams per kilogram) 


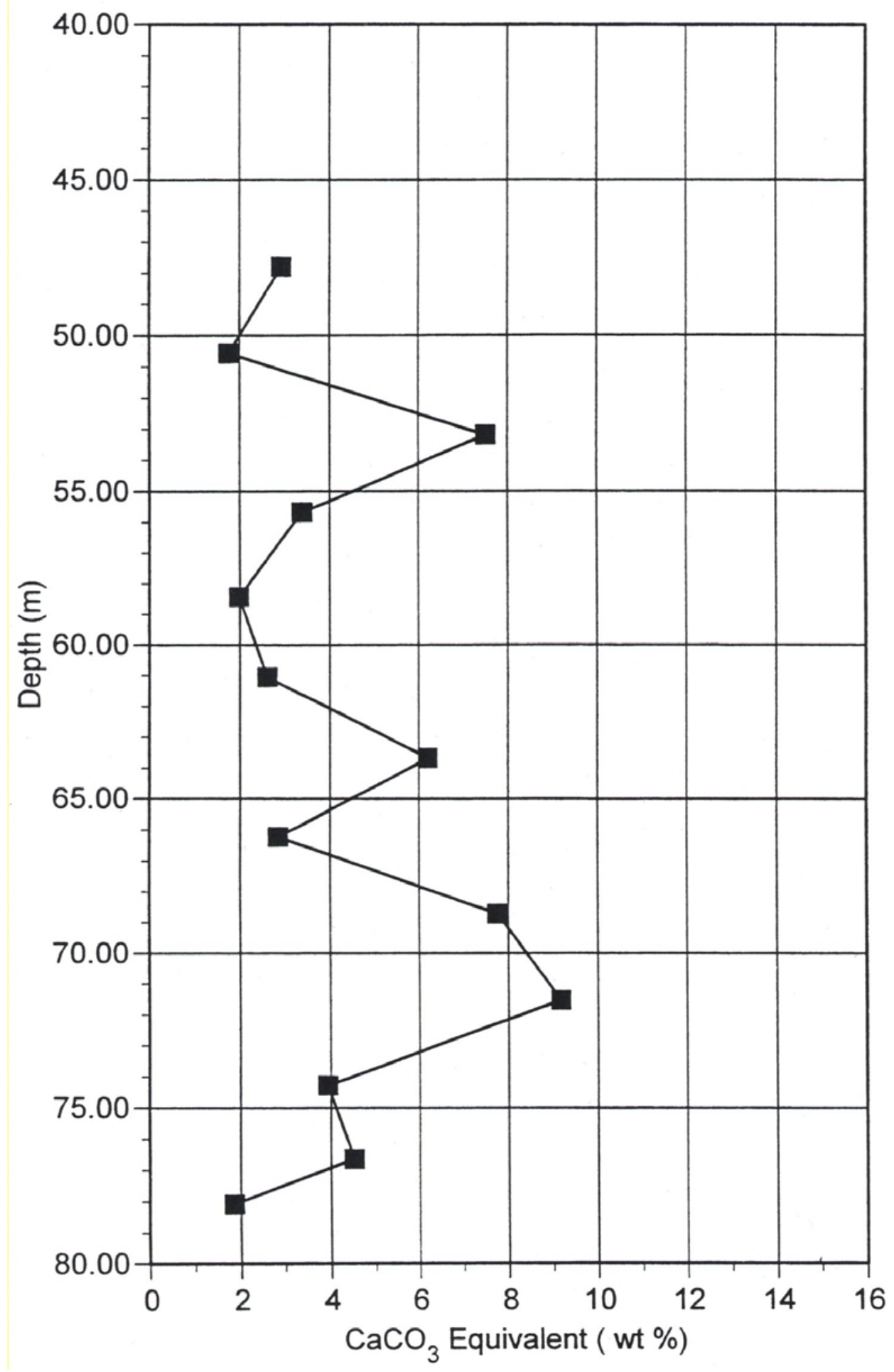

Figure 3-30

Calcium Carbonate Equivalent within the Fine-Earth Fraction (less than 2 millimeters) versus Depth for U-3at-D2

(Oven-dry weight percent) 


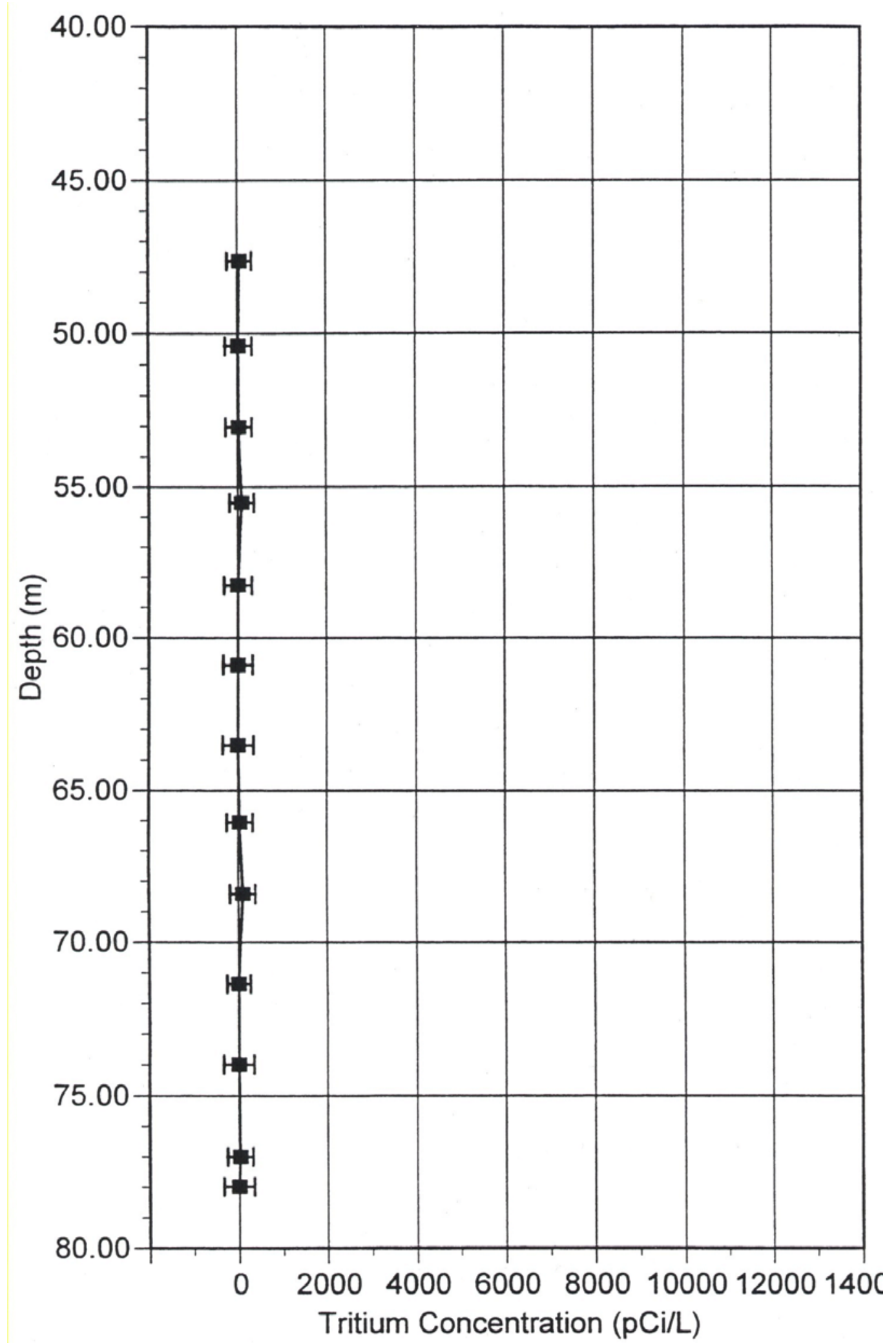

Figure 3-31

Tritium Concentration versus Depth for U-3at-D2

(Bars indicate counting error) 


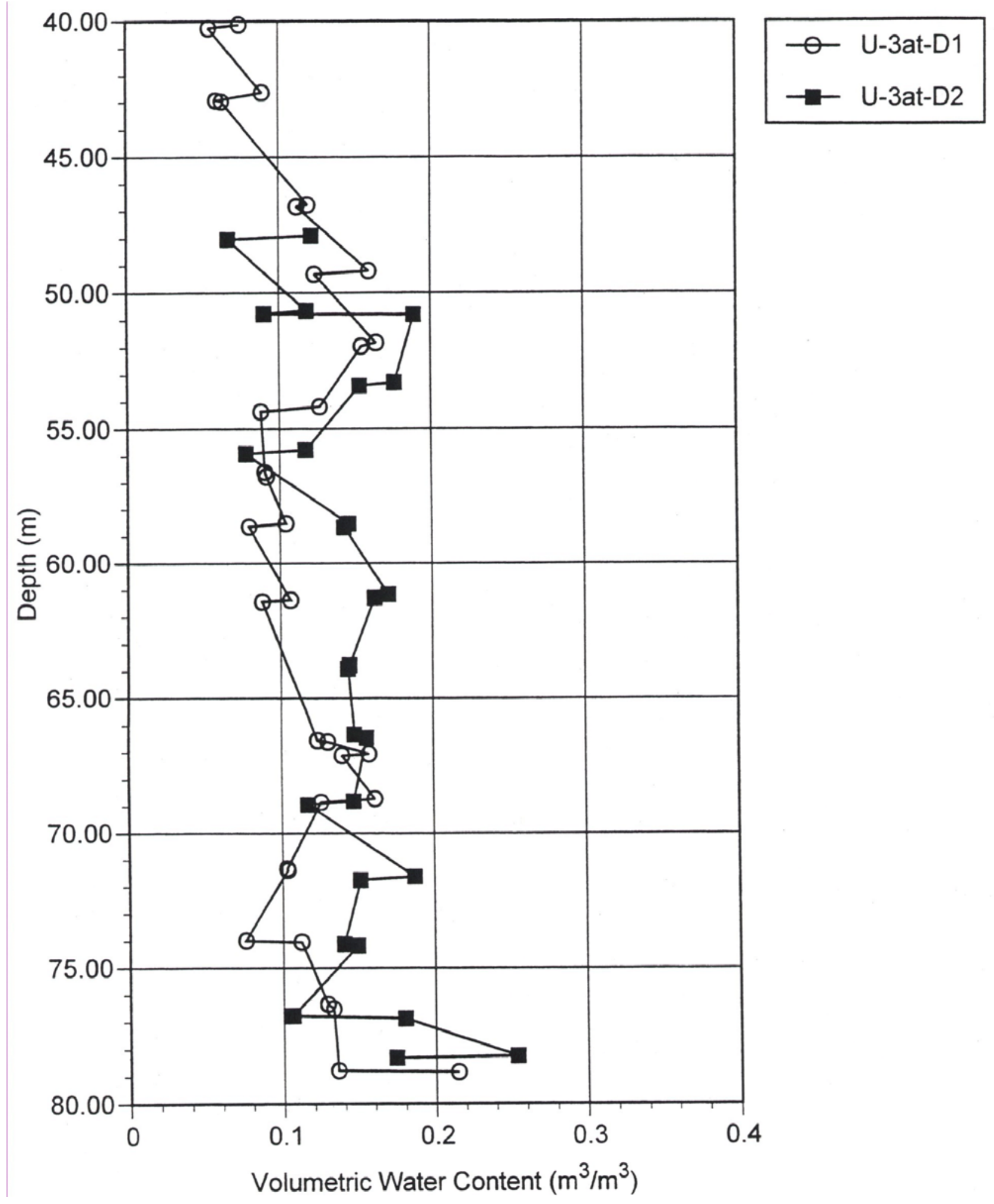

Figure 3-32

Comparison of Volumetric Water Content from 40 to 80 Meters Depth in U-3at-D1 and U-3at-D2

(In cubic meters per cubic meter) 
Water potential plotted versus depth for Borehole D2 is shown in Figure 3-33. Water potential values for a similar depth interval from Borehole D1 are also plotted for comparison. Over the interval sampled, the water potential values from Borehole D2 samples are generally greater than those from Borehole D1, indicating slightly wetter conditions over a portion of the interval.

Stable isotope concentrations in the interval 46.9 to $78.0 \mathrm{~m} \mathrm{(154} \mathrm{to} 256 \mathrm{ft})$ in both boreholes are compared in Figures 3-34 and 3-35. Stable isotope concentrations of pore water from Borehole D2 are compared to the LMWL in Figure 3-36 (see Figure 3-20 for Borehole D1). The results in these figures show that stable isotope concentrations are nearly identical between boreholes.

The above comparisons of water content, water potential, and stable isotope concentrations confirm that water condensed in the compressed air system and excess lubrication oil introduced into the borehole while drilling a portion of Borehole D1 were not sufficient to penetrate core segments used for samples. 


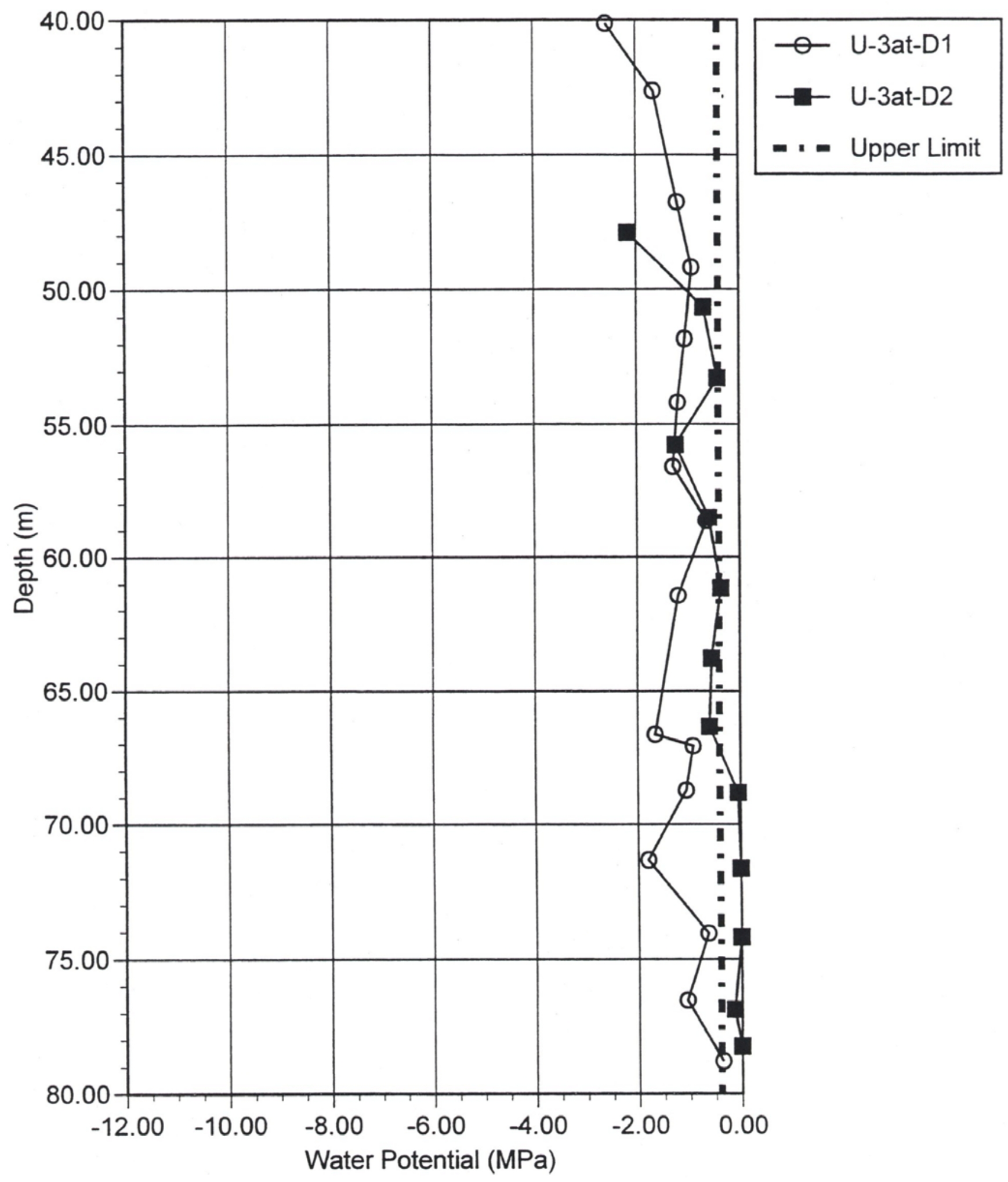

Figure 3-33

Comparison of Water Potential for $\mathbf{4 0}$ to $\mathbf{8 0}$ Meters Depth in U-3at-D1 and U-3at-D2

(The dashed line at -0.4 MegaPascals indicates the upper limit of water potential measurable with water activity meter) 


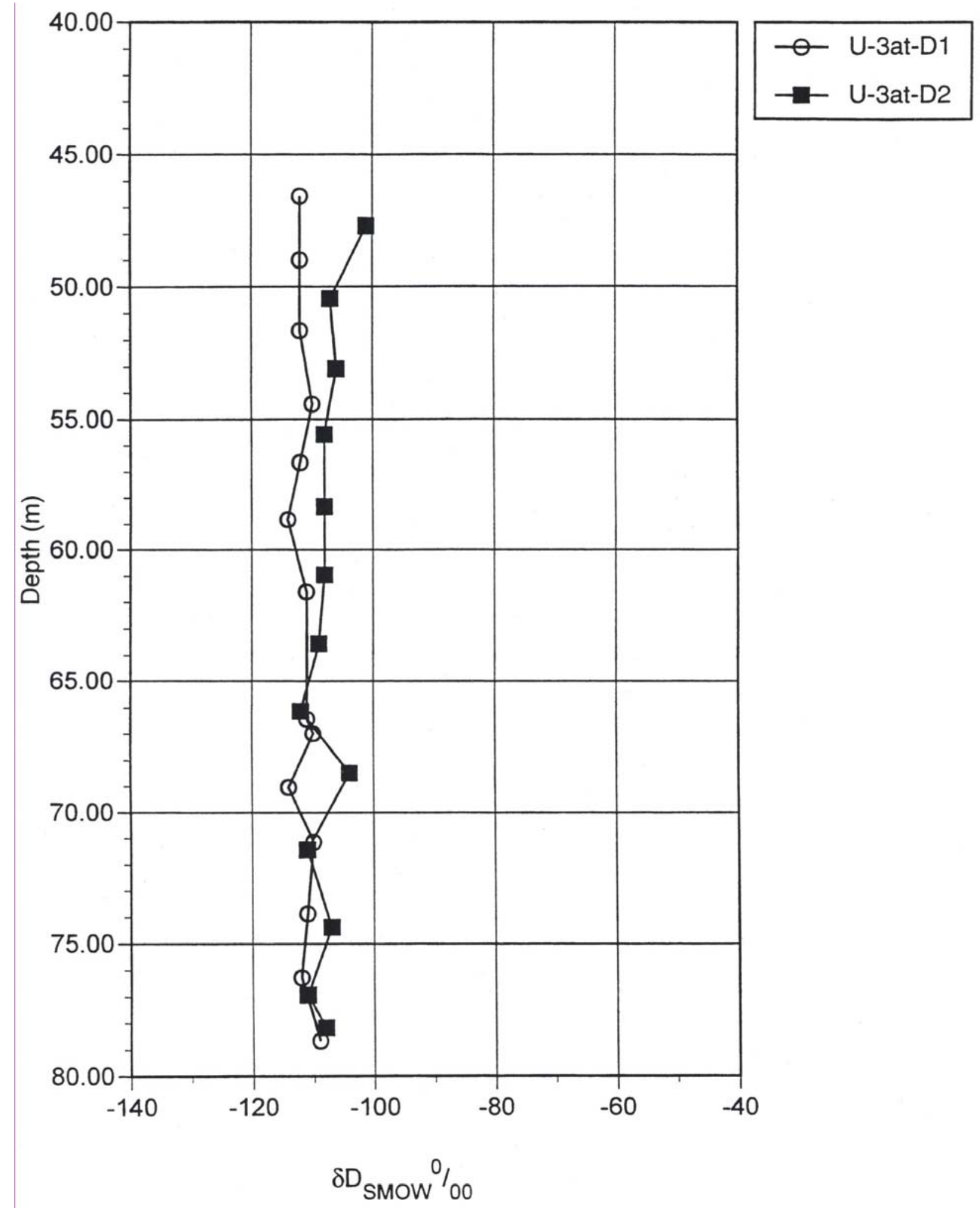

Figure 3-34

Comparison of Deuterium Concentrations in Pore Water from 46 to 78 Meters Depth in U-3at-D1 and U-3at-D2

(Expressed in standard delta notation relative to standard mean ocean water in parts per thousand) 


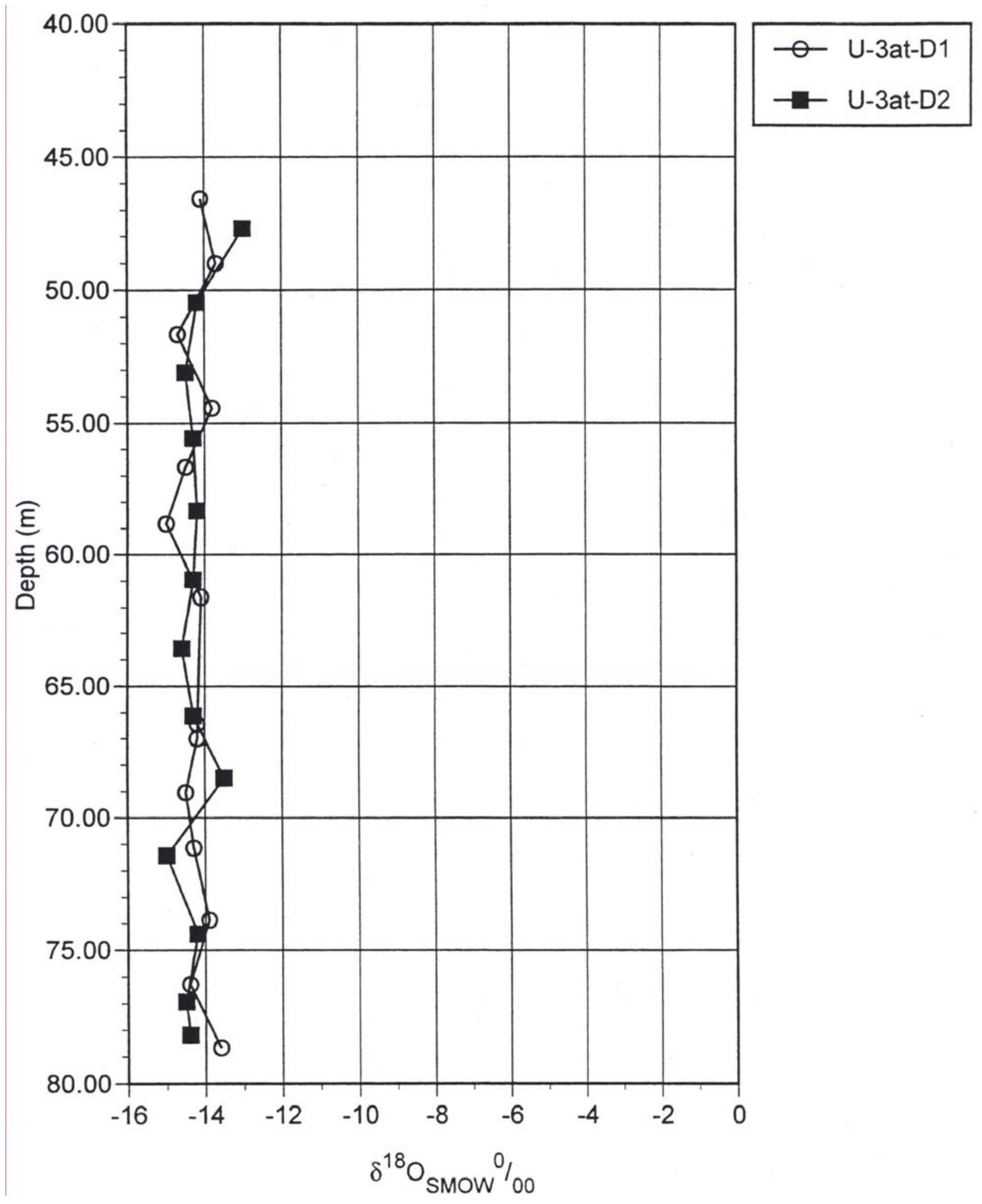

Figure 3-35

Comparison of Oxygen-18 Concentrations in Pore Water from 46 to 78 Meters Depth in U-3at-D1 and U-3at-D2

(Expressed in standard delta notation relative to standard mean ocean water in parts per thousand) 

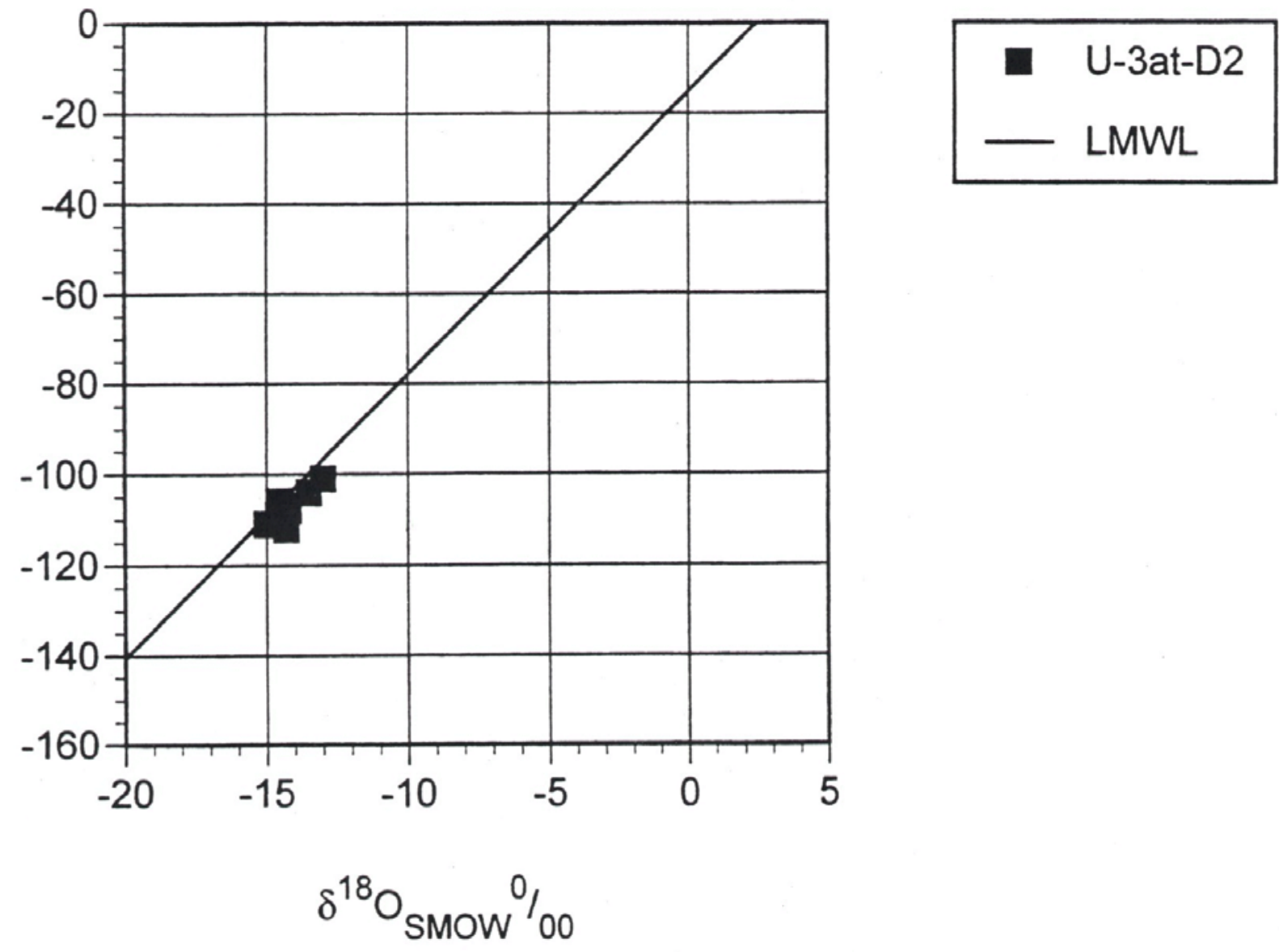

Figure 3-36

Comparison of Stable Isotope Concentrations in Pore Water from U-3at-D2 and Local Meteoric Water Line (LMWL)

(Expressed in standard delta notation relative to standard mean ocean water in parts per thousand) 


\subsection{Summary}

Two angled boreholes were drilled in 1996 to intercept the disturbed alluvium of the collapse zone (rubble chimney) beneath the U-3at subsidence crater. This subsidence crater, produced by the underground nuclear test JERBOA in 1963, is located in the Area 3 RWMS. The crater has served as a waste disposal unit for low-level bulk radioactive waste since 1988. Borehole U-3at-D1 was drilled to an equivalent vertical depth of $147.3 \mathrm{~m}$ (484.4 ft). Borehole U-3at-D2 was drilled nearby to a vertical depth of $78.3 \mathrm{~m}(256.9 \mathrm{ft})$ to verify the results from the first borehole.

Geologic and hydrologic observations and measurements were made on core samples from the two boreholes to obtain hydrogeologic characterization in support of modeling and closure planning for the waste disposal site. These data may also be used to address the issue of whether preferential pathways for the movement of contaminants in fluids from the waste disposal site might exist as a result of activities related to the U-3at JERBOA underground nuclear test.

A review of activities related to construction and execution of the U-3at JERBOA test indicated that an un-welded casing joint, the presence of instrumentation cables for which gas-blocks were not installed within the emplacement hole, and the unknown status of post-shot drill holes may be potential pathways for high-pressure gases produced by the explosion. However, it is uncertain whether these potential pathways could also be preferential pathways for the downward movement of water.

Particle density and dry bulk density values show no trends with depth. Water retention relations and hydraulic conductivity values, while variable, are relatively consistent for the cores tested, are typical for the other soils of similar texture, and show no trend with depth. Water content and water potential values tend to increase with depth.

In general, enrichment in heavy isotopes of hydrogen and oxygen in pore water is seen near the land surface, and is caused by evaporation. Accumulation of chloride is also seen in the nearsurface sediments, which is typical of arid regions. Tritium concentrations in pore water are below the detection limits from the surface to a depth of $119 \mathrm{~m}(390 \mathrm{ft})$. Below this depth, concentrations generally increase to a maximum of 2,200 pCi/L in the deepest sample at $146.9 \mathrm{~m}$ $(482 \mathrm{ft})$. This tritium most likely originated as a product of the nuclear test.

A comparison of water content, water potential, and stable isotope concentrations for the two boreholes confirmed that water condensed in the compressed air system and excess lubrication oil introduced into the borehole while drilling a portion of Borehole D1 were not sufficient to penetrate core segments used for samples. 
This page intentionally left blank. 


\subsection{References Cited}

Bechtel Nevada, 1998a. Hydrogeologic Characterization of U-3bl Collapse Zone. DOE/NV/11718--197. Las Vegas, NV.

Bechtel Nevada, 1998b. Hydrogeologic Characterization of U-3bh Collapse Zone. DOE/NV/11718--198. Las Vegas, Nevada.

Bechtel Nevada, 2005. Site Characterization Data from U3ax/bl Exploratory Boreholes at the Nevada Test Site. DOE/NV/11718--003-REV.1. Las Vegas, NV.

BN, see Bechtel Nevada.

Borg, I. Y., R. Stone, H. B. Levy, and L. D. Ramspott, 1976. Information Pertinent to the Migration of Radionuclides in Ground Water, Part I: "Review and Analysis of Existing Information.” Lawrence Livermore National Laboratory Report UCRL-52078.

DOE, see U.S. Department of Energy.

Gee, G. W., M. D. Campbell, G. S. Campbell, and J. H. Campbell, 1992. Rapid Measurement of Low Soil Water Potential Using a Water Activity Meter. Soil Science Society of America Journal, vol. 56, pp. 1,068-1,071.

Hammermeister, D. P., D. O. Blout, and J. C. McDaniel, 1986. "Drilling and Coring Methods that Minimize the Disturbance of Cuttings, Core, and Rock Formations in the Unsaturated Zone, Yucca Mountain, Nevada.” In: Proceedings of the NWWA Conference on Characterization and Monitoring of the Vadose (Unsaturated) Zone, Denver, CO, 1985, pp. 506-541. National Water Well Association, Worthington, OH.

Hawkins, W. L. 1994. Written communication. Subject: "Data Report and Review U3ax/bl Site Characterization and Closure" Prepared for U. S. Department of Energy/Nevada Operations Office, Las Vegas, Nevada. Los Alamos National Laboratory, Los Alamos, NM.

Plannerer, H. N., 1996. Siting Criteria for Angle Drilling Under the U-3ah/at Disposal Unit. Los Alamos National Laboratory Report LA-UR-96-1679, Los Alamos, New Mexico.

Shott, G. J., V. Yucel, M. J. Sully, L. E. Barker, S. E. Rawlinson, and Beth A. Moore, 1997. Performance Assessment/Composite Analysis for the Area Radioactive Waste Management Site at the Nevada Test Site, Nye County, Nevada Revision 2.0, U.S. Department of Energy Report DOE/NV-491.

Soils Survey Staff, 1993. "Examination and Description of Soils,” Chapter 3. In: Soil Survey Manual, U.S. Department of Agriculture Handbook Number 18. Washington, D.C., U.S. Government Printing Office, p. 59-195.

SORD, see Special Operations and Research Division.

Special Operations and Research Division of Air Resources Laboratory. Website containing archived data accessed June 22, 2005.

<http://www.sord.nv.doe.gov/products/climate/monthly_temp_summaries/meda-03/1996/> 
Tyler, S. W., W. A. McKay, and T. M. Mihevc, 1992. Assessment of Soil Moisture Movement in Nuclear Subsidence Craters. Journal of Hydrology, vol. 139, pp. 159-181.

Tyler, S. W., J. B. Chapman, S. H. Conrad, D. P. Hammermeister, D. O. Blout, J. J. Miller, M. J. Sully and M. J. Ginanni, 1996. Soil-Water Flux in the Southern Great Basin, United States Temporal and Spatial Variations over the Last 120,000 Years. Water Resources Research, vol. 32, pp. 1,481-1,499.

U. S. Congress, Office of Technology Assessment, 1989. The Containment of Underground Nuclear Explosions. OTA-ISC-414. U.S. Government Printing Office, Washington, DC.

USDA, see Soils Survey Staff.

U.S. Department of Energy, 1996a. The Environmental Impact Statement for the Nevada Test Site and Off-Site Locations in the State of Nevada. DOE/EIS 0243. Las Vegas, Nevada.

U.S. Department of Energy, 1996b. Guidance for a Composite Analysis of the Impact of Interacting Source Terms of the Radiological Protection of the Public From Department of Energy Low-Level Waste Disposal Facilities. U.S. Department of Energy, Washington, DC.

U.S. Department of Energy, 2001. Radioactive Waste Management. DOE Order 435.1, U.S. Department of Energy, Washington, DC. 


\section{Distribution List}

\section{U. S. Department of Energy}

Jhon Carilli

Waste Management Division

U.S. Department of Energy

National Nuclear Security Administration

Nevada Site Office

P.O. Box 98518, M/S 505

Las Vegas, NV 89193-8518

B. M. Crowe

Apogen Technologies

U.S. Department of Energy

National Nuclear Security Administration

Nevada Site Office

P.O. Box 98518, M/S 505

Las Vegas, NV 89193-8518

U.S. Department of Energy

National Nuclear Security Administration

Nevada Site Office

Technical Library

P.O. Box 98518, M/S 505

Las Vegas, NV 89193-8518

U.S. Department of Energy

National Nuclear Security Administration

Nevada Site Office

Public Reading Facility

c/o Nuclear Testing Archive

P.O. Box 98518, M/S 400

Las Vegas, NV 89193-8518

U.S. Department of Energy

Office of Scientific and Technical Information

P.O. Box 62

Oak Ridge, Tennessee 37831-0062

\section{Bechtel Nevada}

Max Dolenc

Bechtel Nevada

1 (uncontrolled)

2 (electronic, uncontrolled)

1 (electronic, uncontrolled)

P.O. Box 98521, M/S NSF080

Las Vegas, NV 89193-8521 


\section{Distribution List (continued)}

\section{$\underline{\text { Copies }}$}

Environmental Management Library

1

Bechtel Nevada

P.O. Box 98521, M/S NLV094

Las Vegas, NV 89193-8521

Steve Nacht

Bechtel Nevada

P.O. Box 98521, M/S NSF083

Las Vegas, NV 89193-8521

Stuart Rawlinson

Bechtel Nevada

P.O. Box 98521, M/S NTS416

Las Vegas, NV 89193-8521

Dan Tobiason

Bechtel Nevada

P.O. Box 98521, M/S NTS416

Las Vegas, NV 89193-8521 


\title{
U3at Collapse Zone
}

\author{
Appendix A
}

\section{Borehole Log Sheets for \\ Exploratory Boreholes U-3at-D1 and U-3at-D2}




\title{
Legend for Borehole Log Sheets
}

\author{
ARCH Archive sample \\ $\mathrm{BN}$ \\ Bechtel Nevada sample \\ C Common: although not dominant, prevalent throughout the sample \\ COLOR Refer to Munsell Soil Color Chart that defines hue, value (brilliance), and chroma \\ (purity) \\ D Dominant: primary constituent of sample \\ DRI Desert Research Institute sample \\ HF Huffman Laboratories, Inc. sample \\ LL Lawrence Livermore National Laboratory sample \\ NW Northwest Laboratory sample \\ P Present: occurs regularly throughout the sample \\ $\mathrm{R} \quad$ Rare: occurs infrequently in the sample \\ USCS Unified Soil Classification System; refer to American Society of Testing and \\ Materials (1984) for a listing of appropriate group symbols.
}




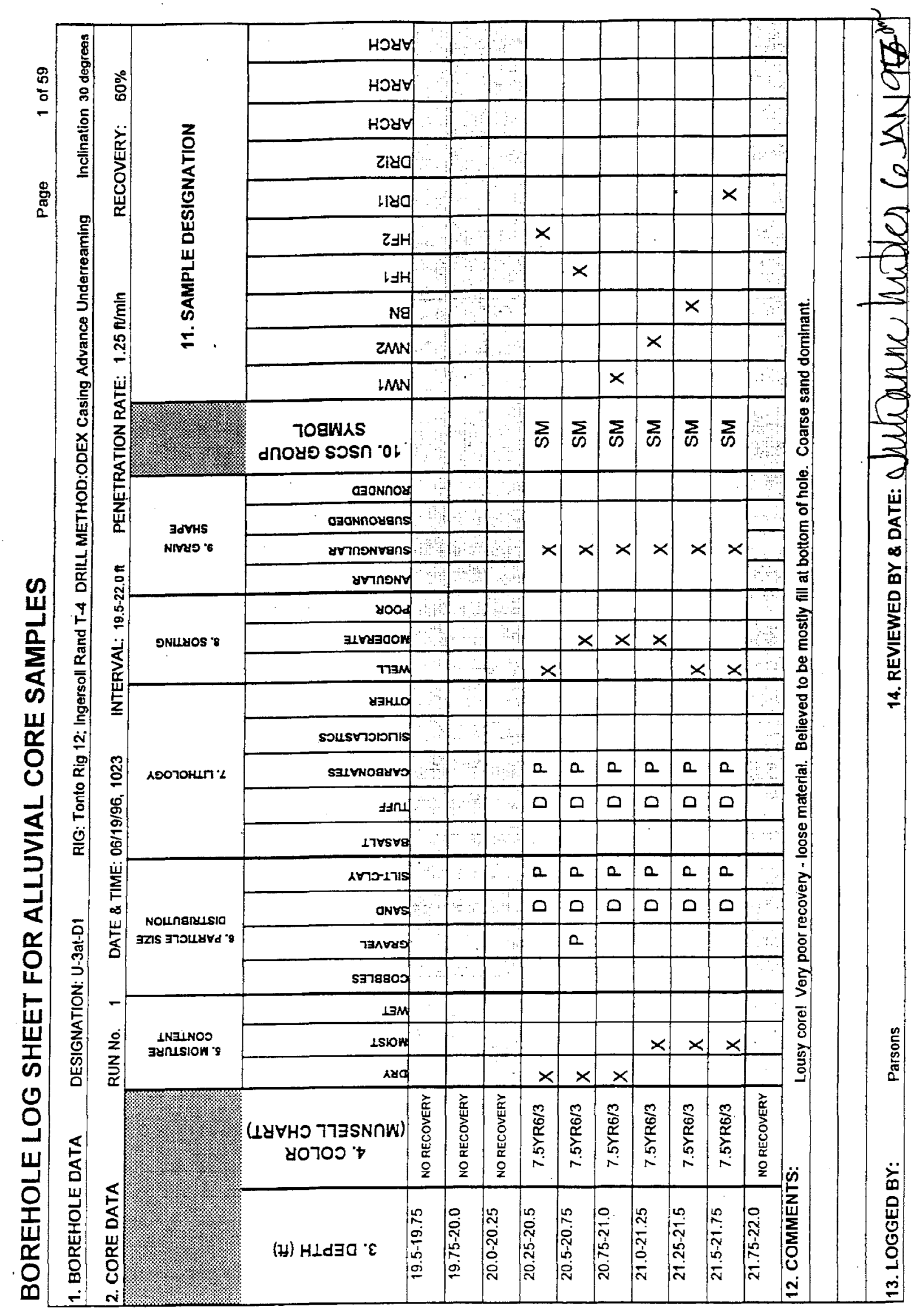




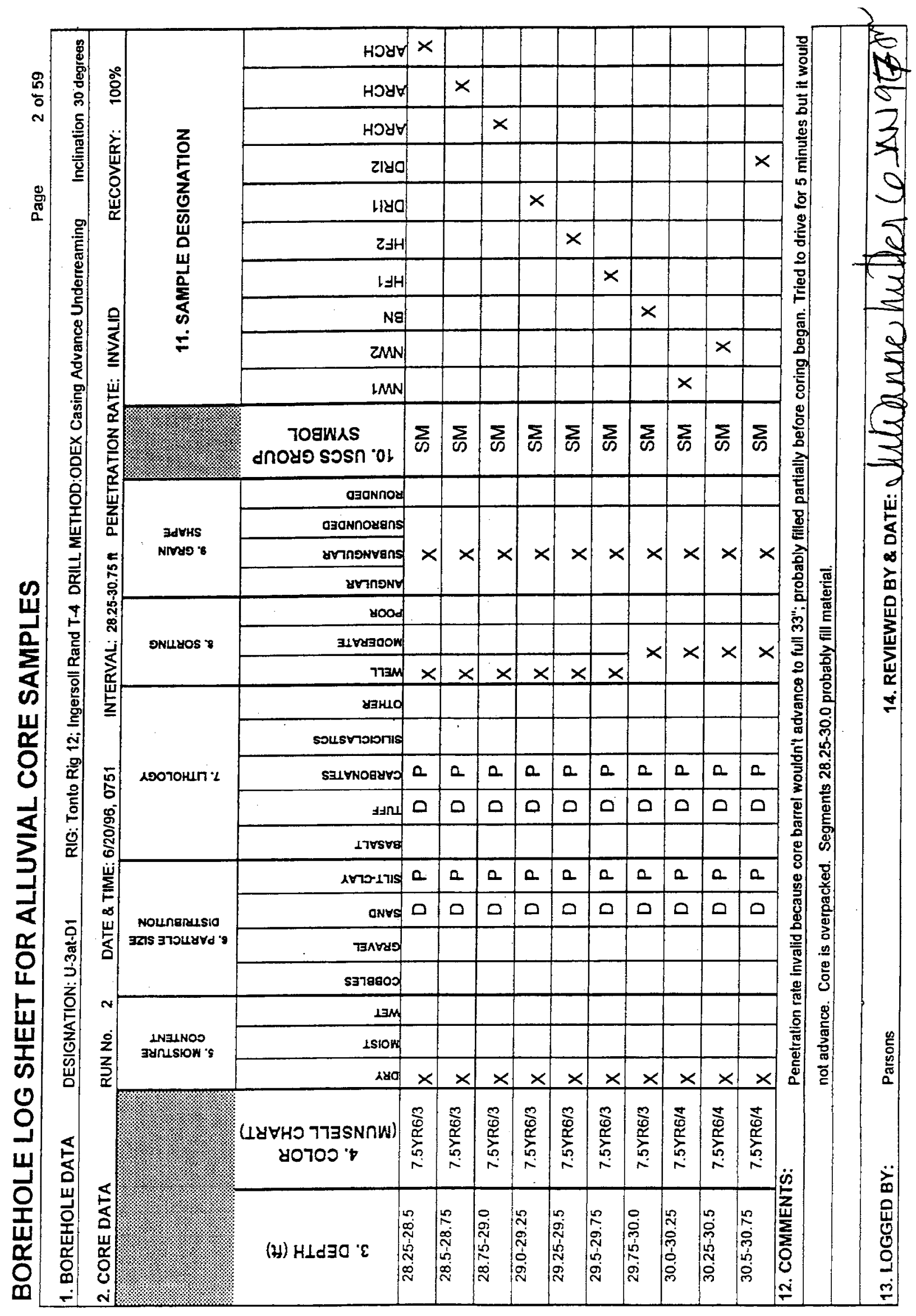




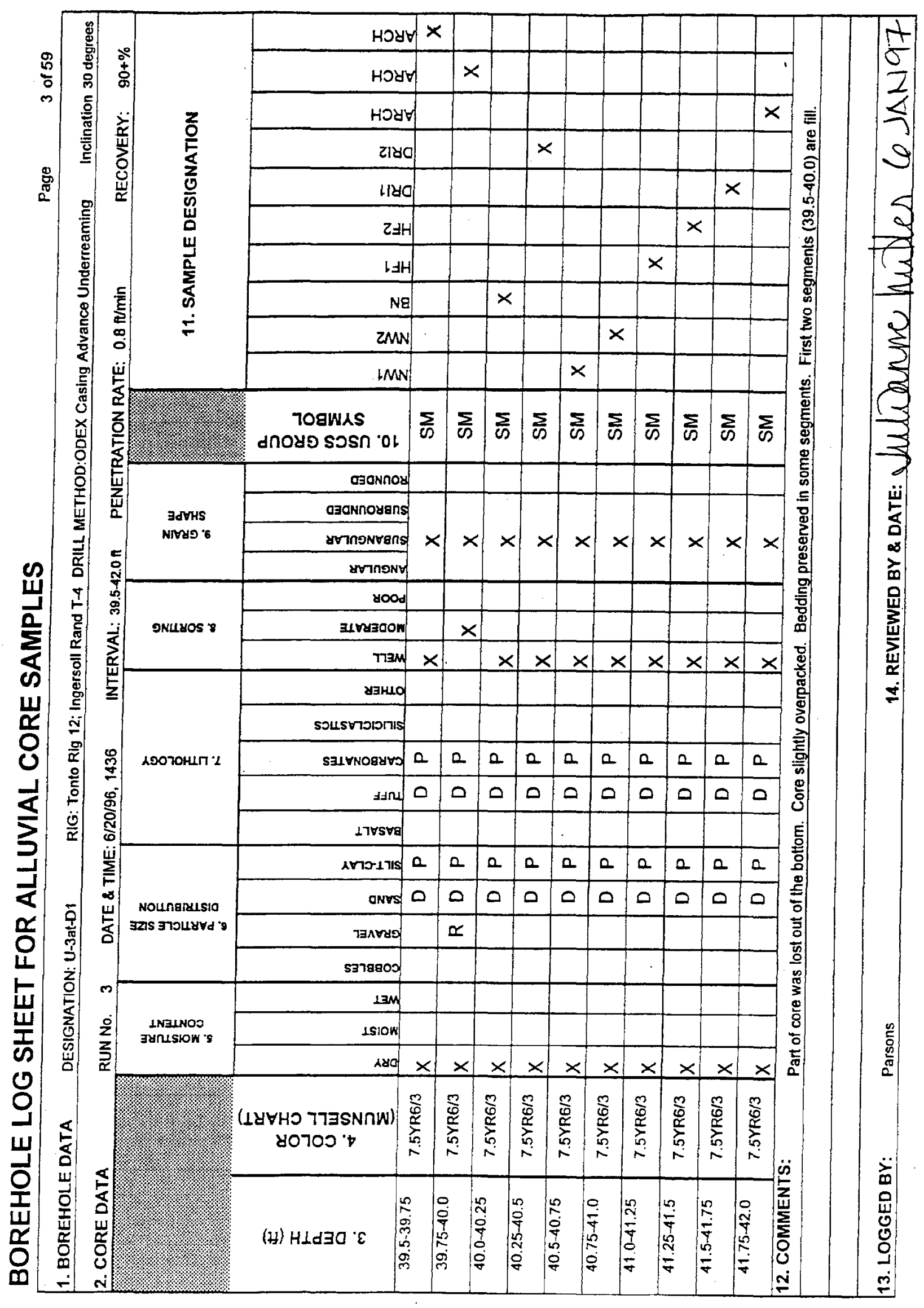




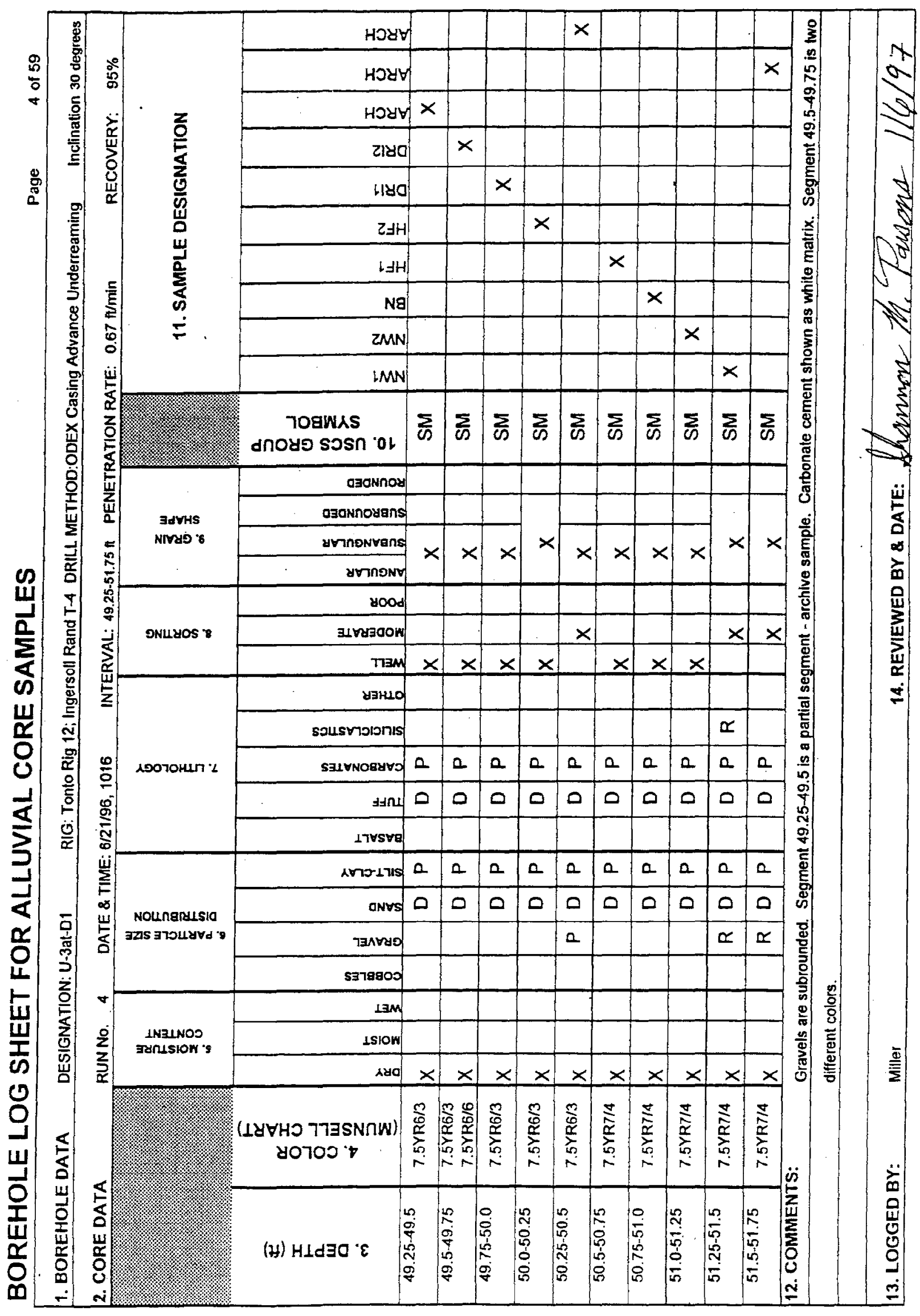




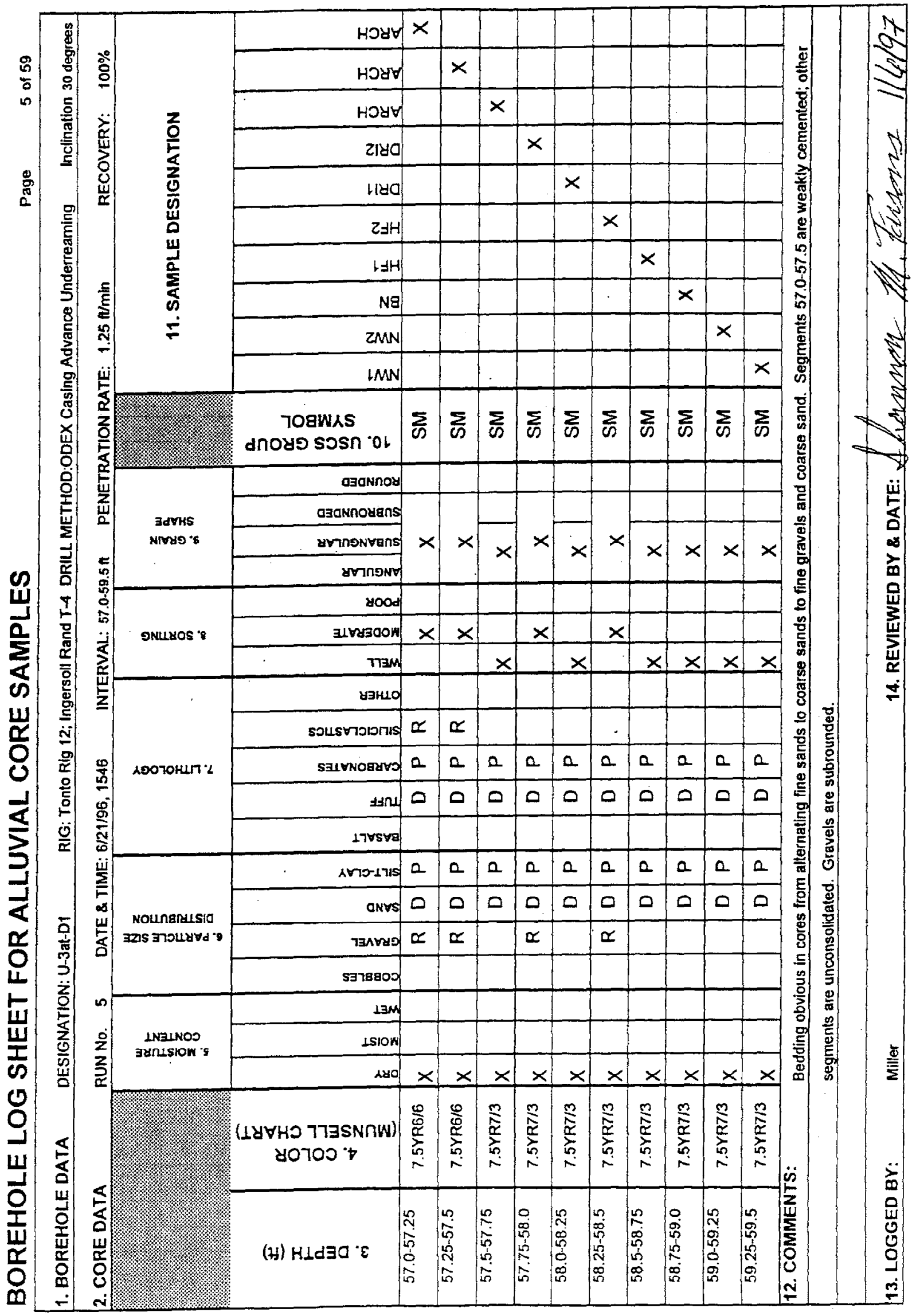




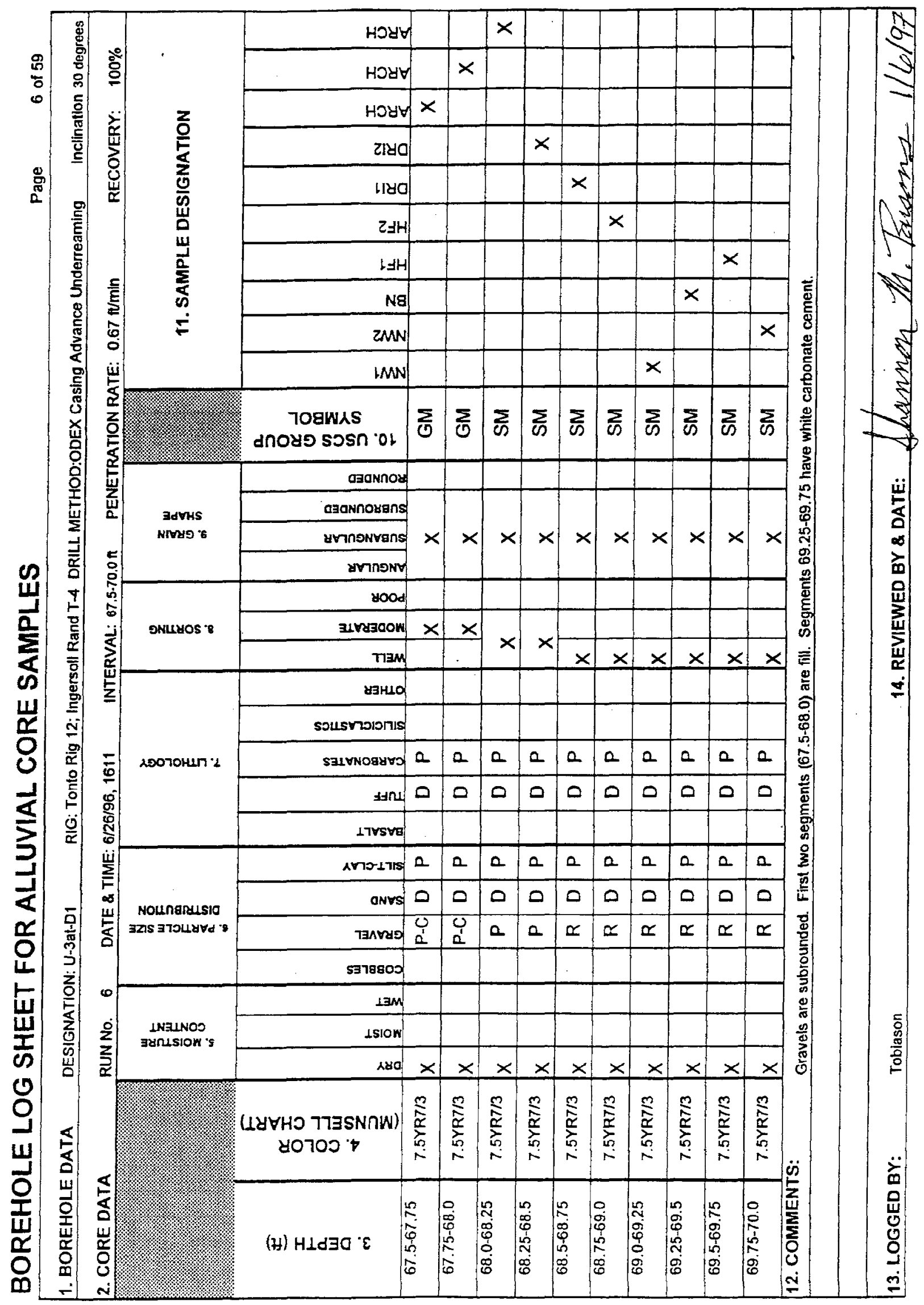




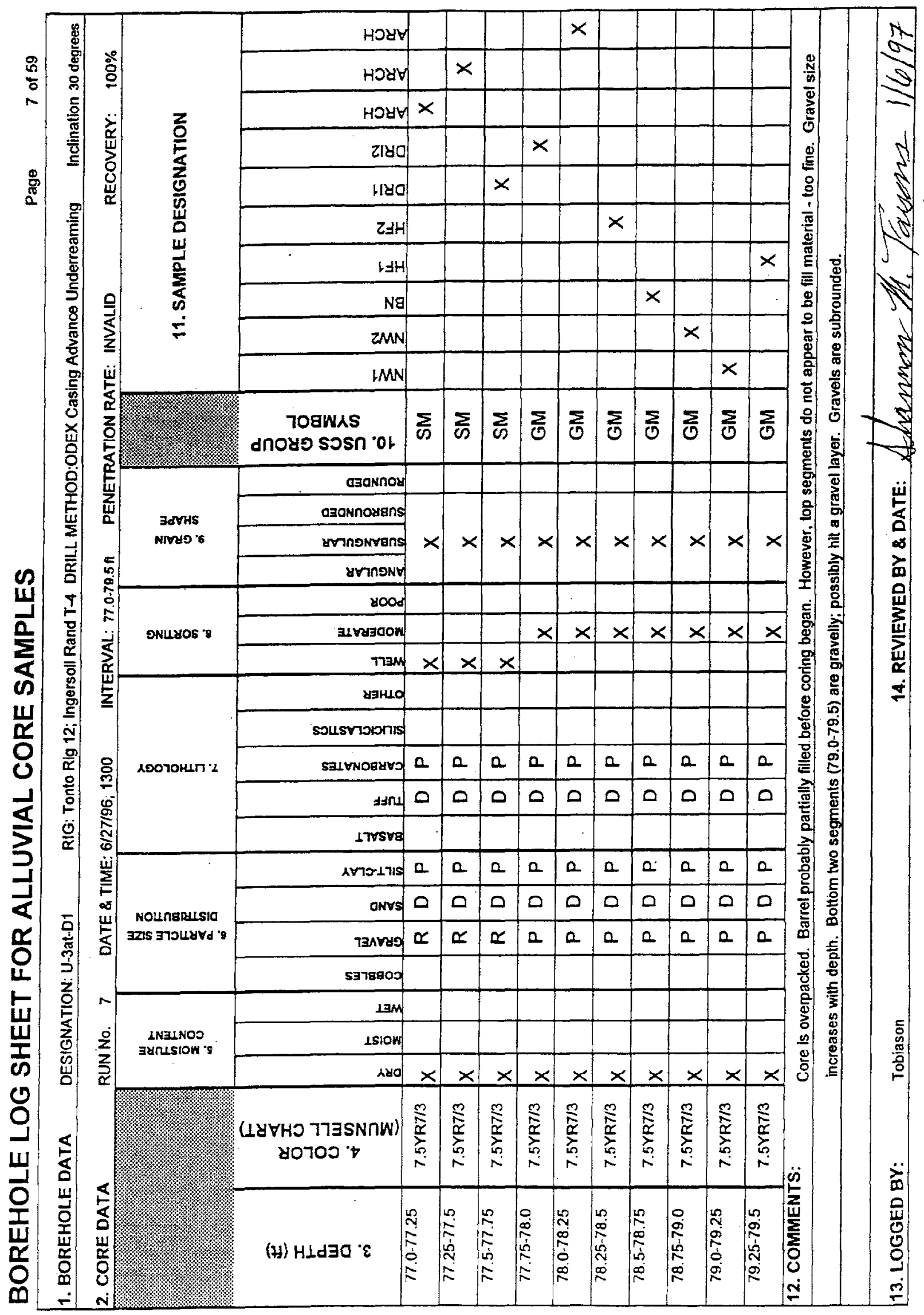




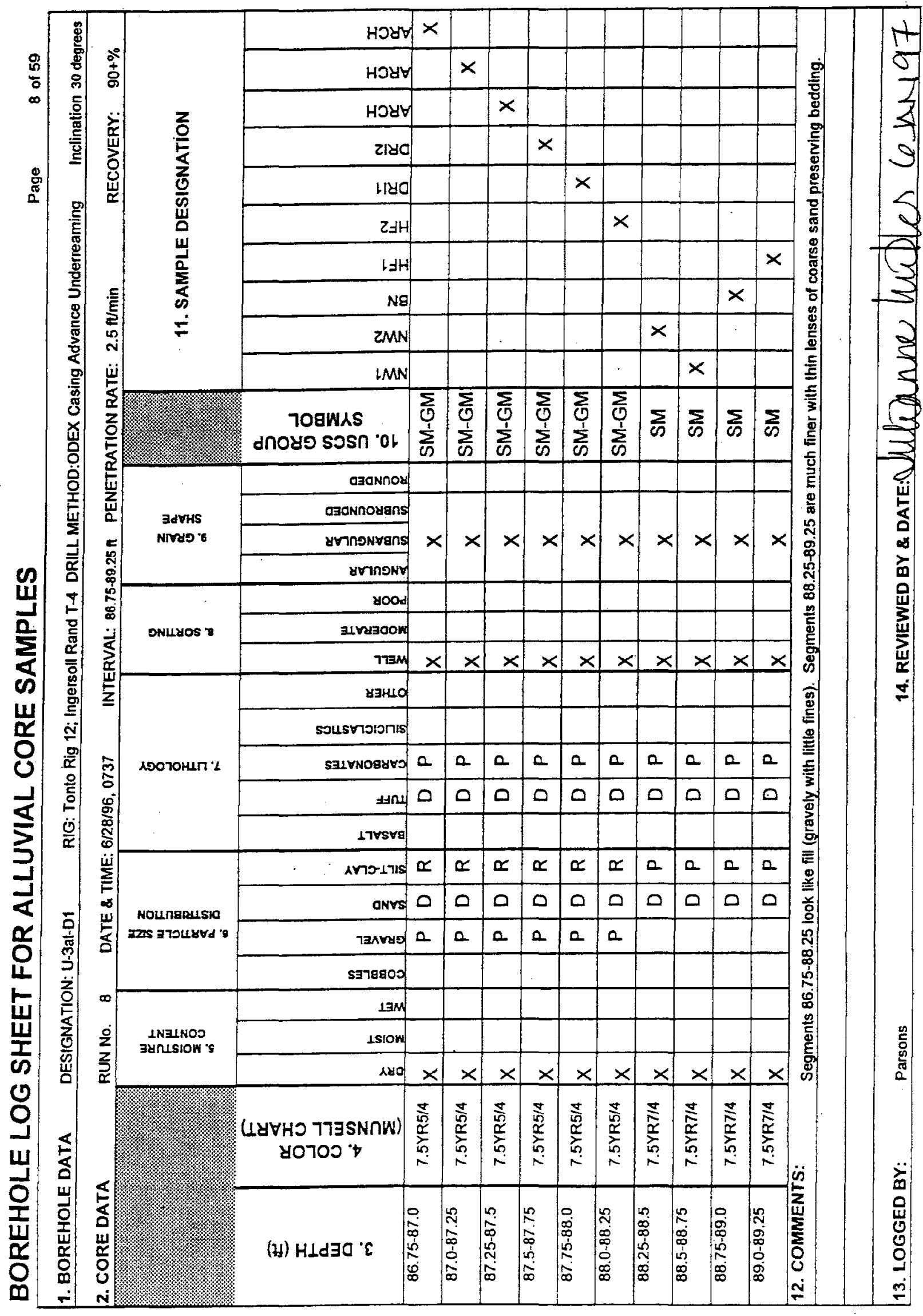




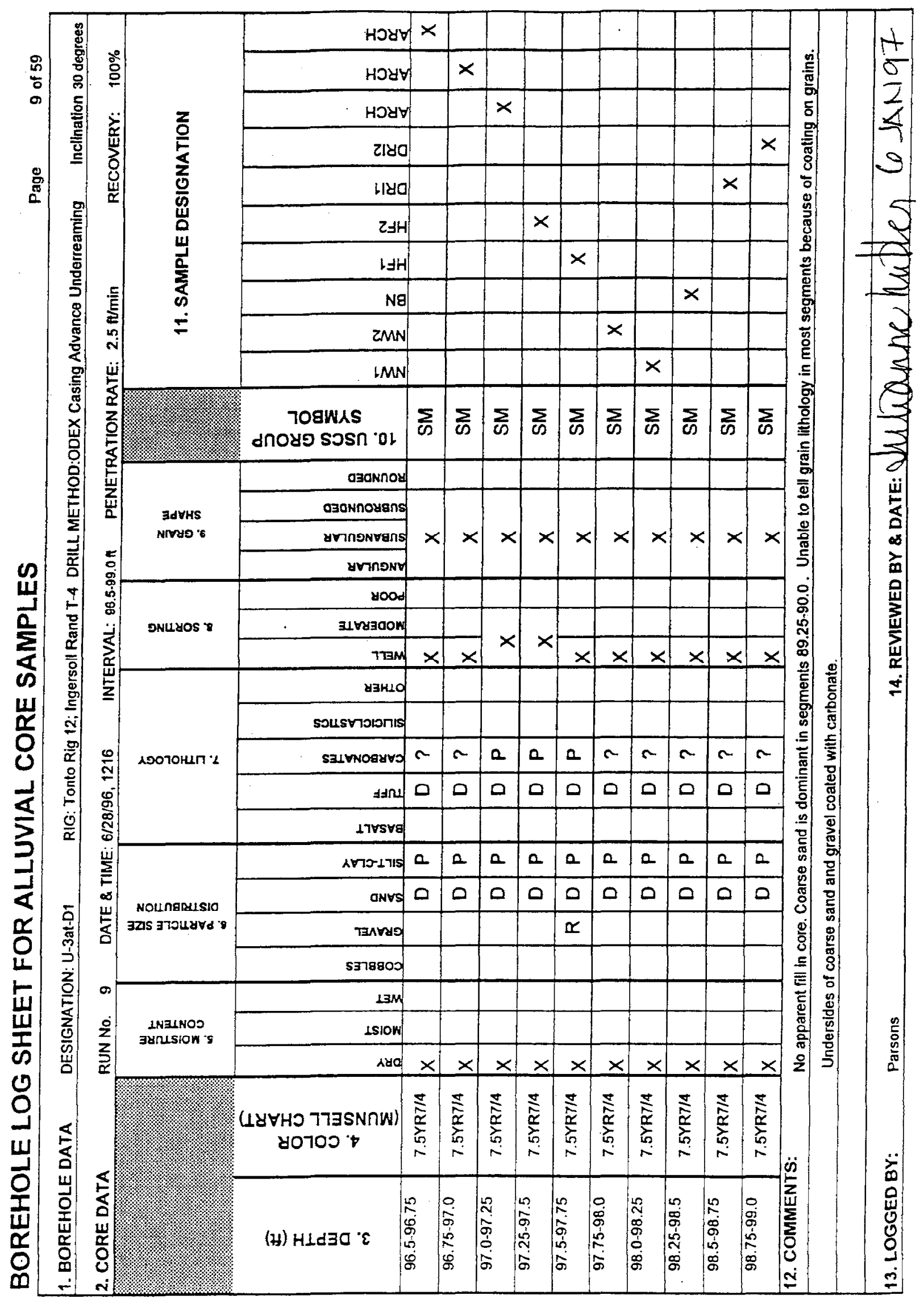




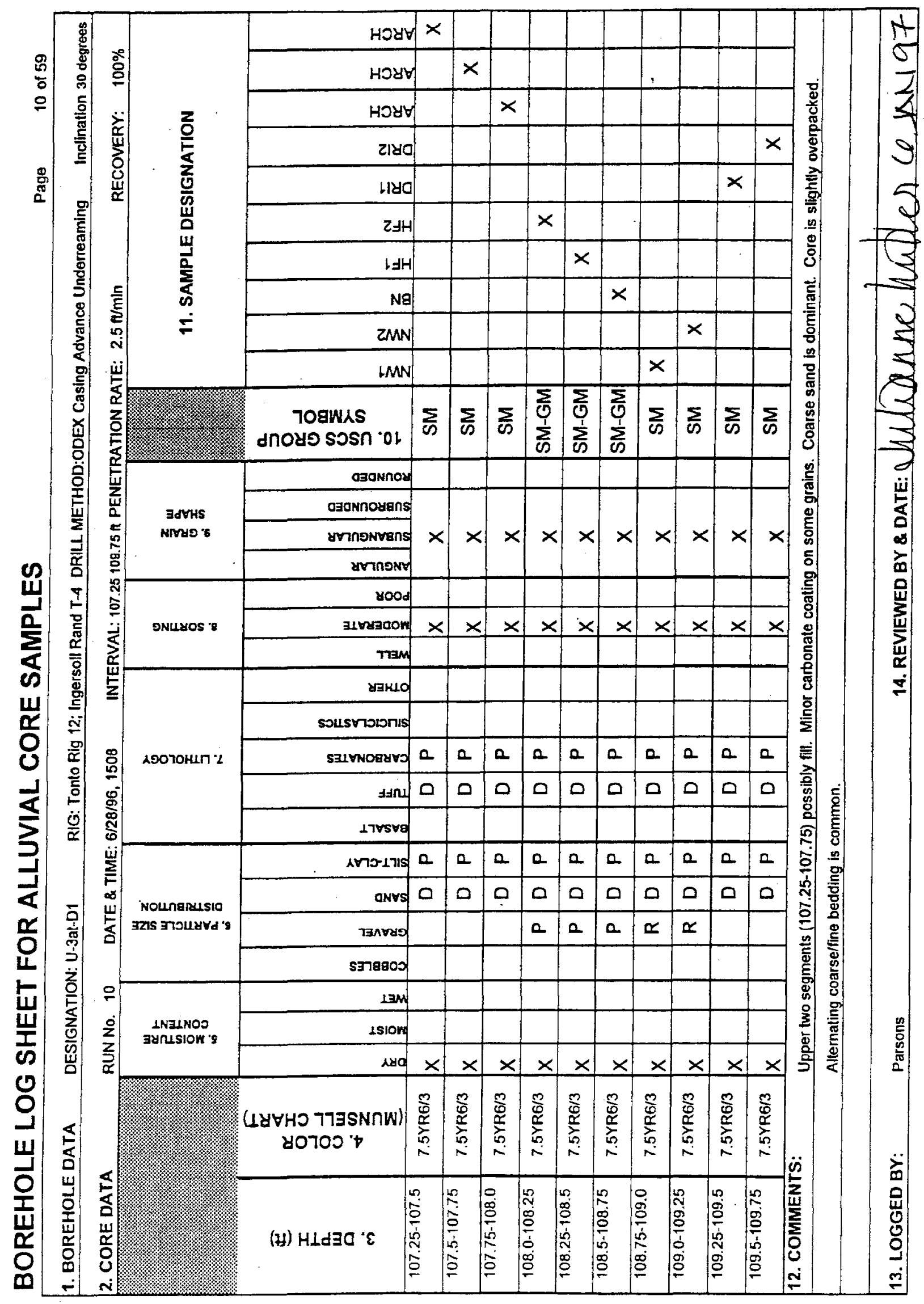




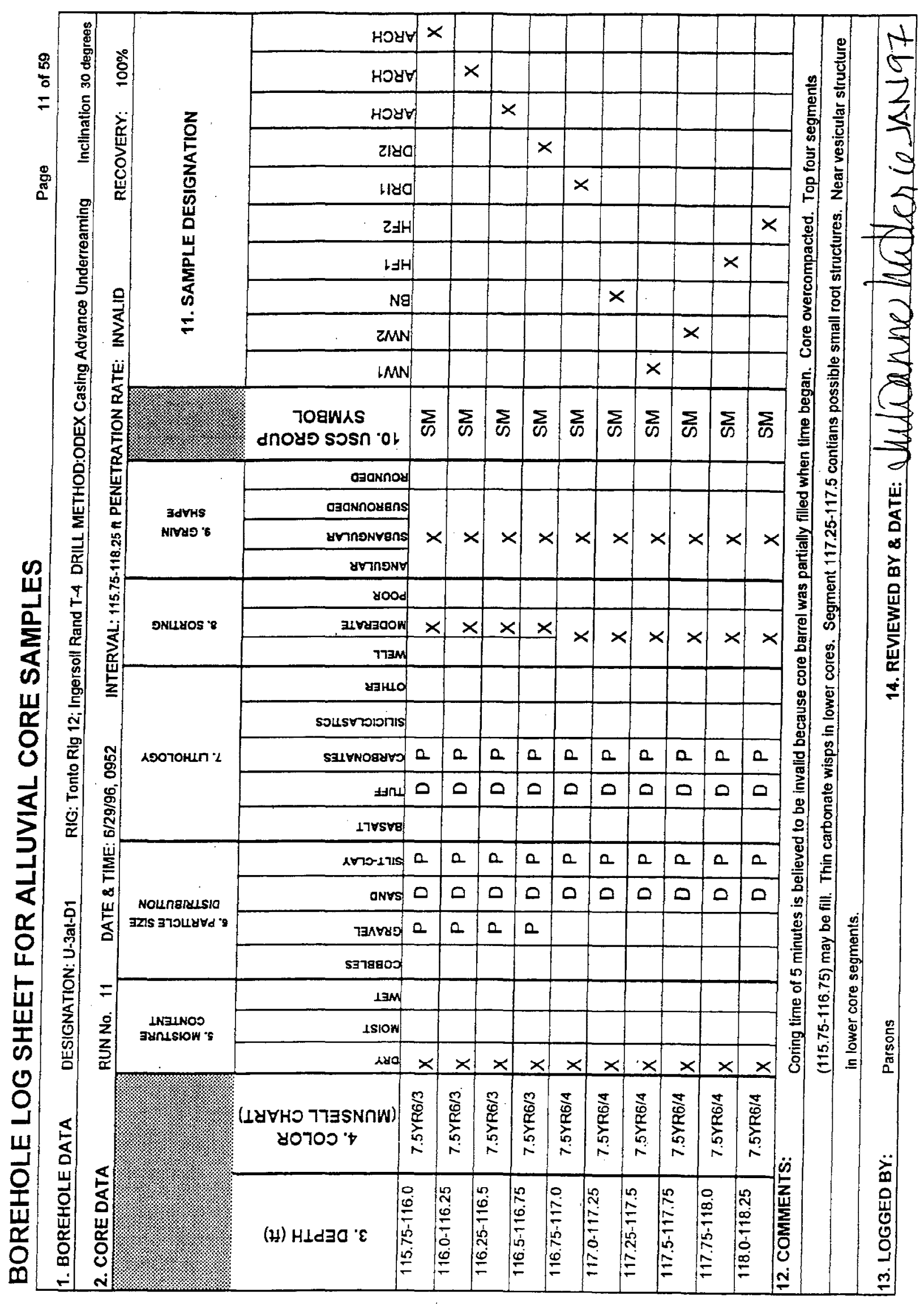




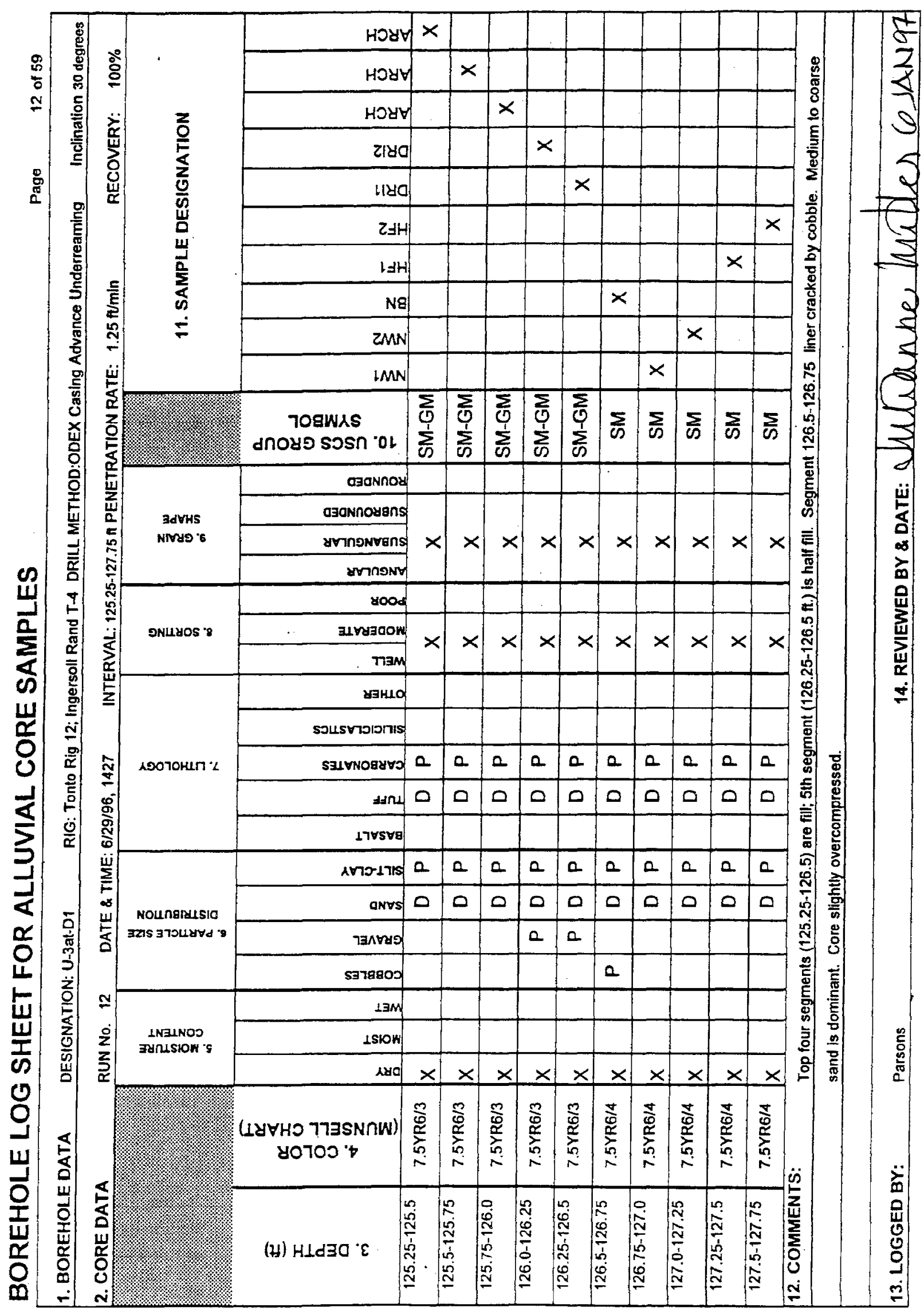




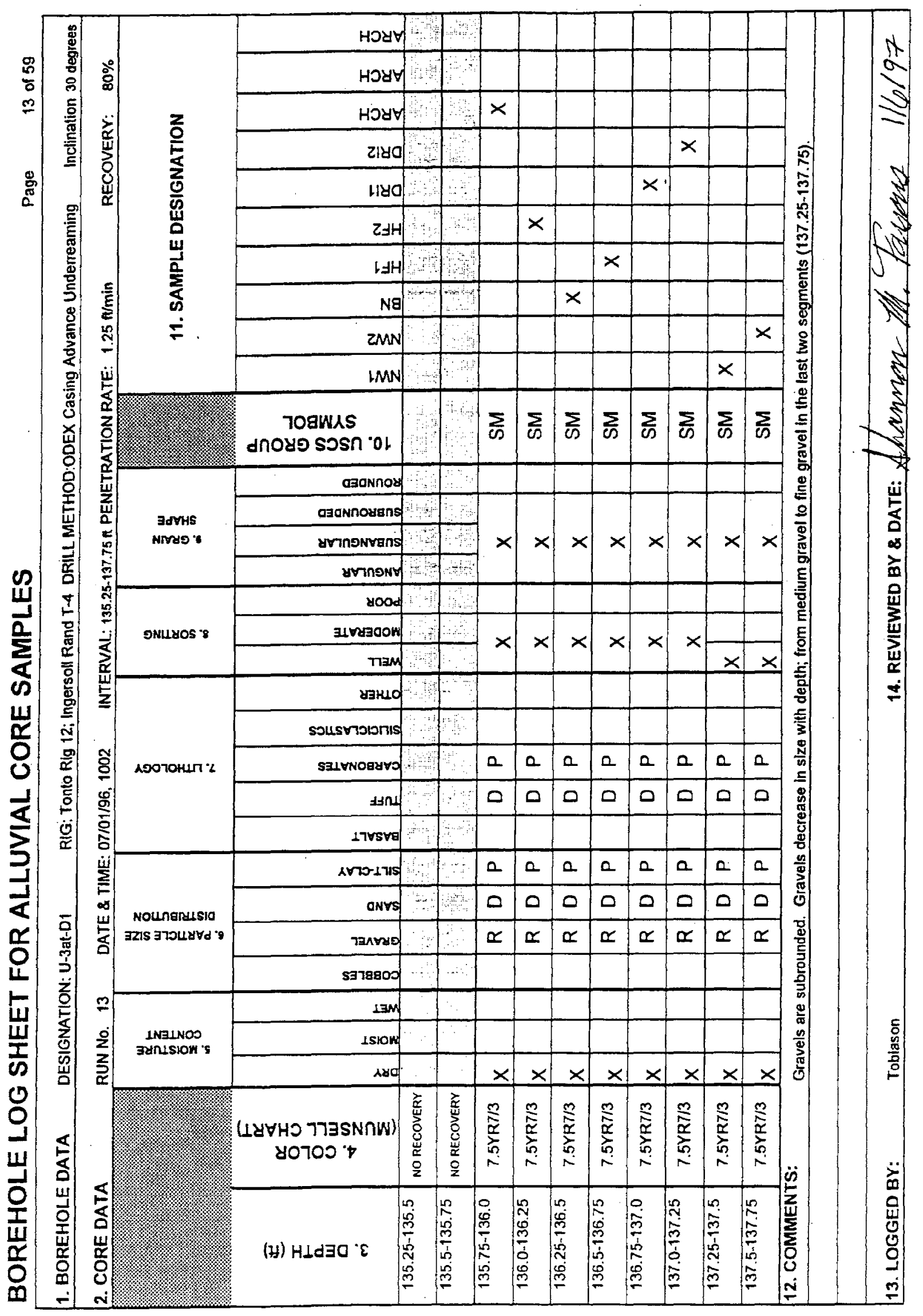




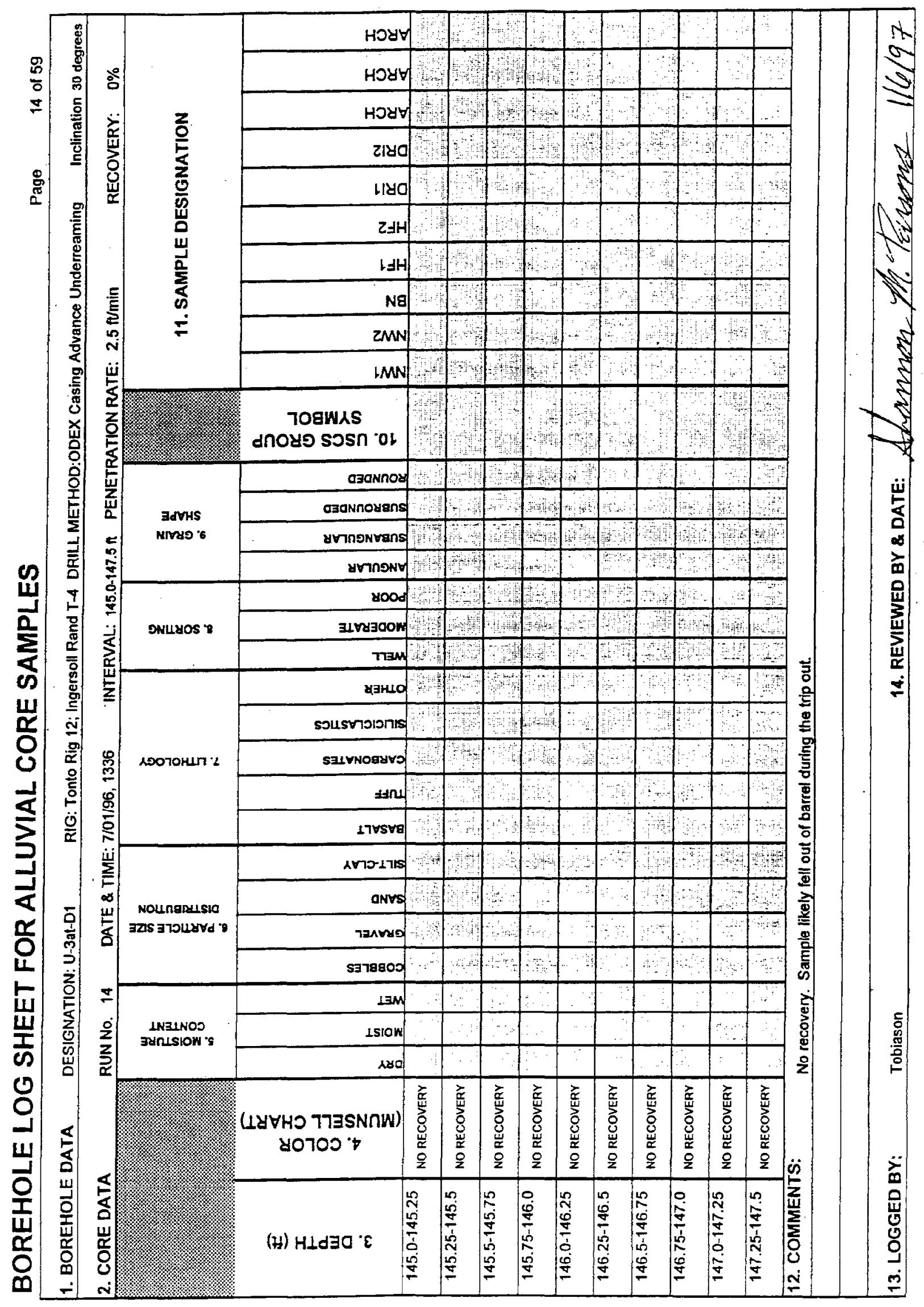




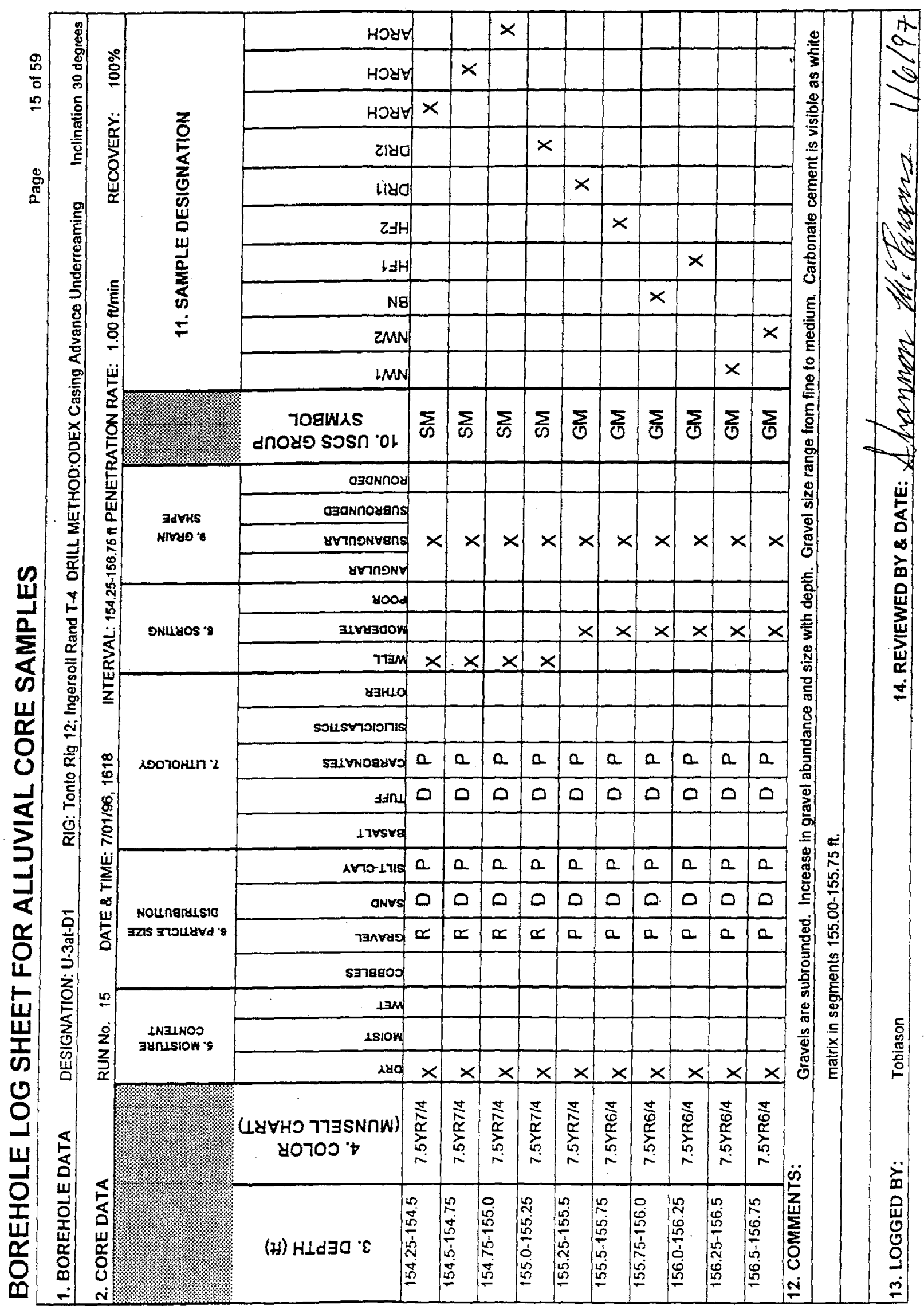




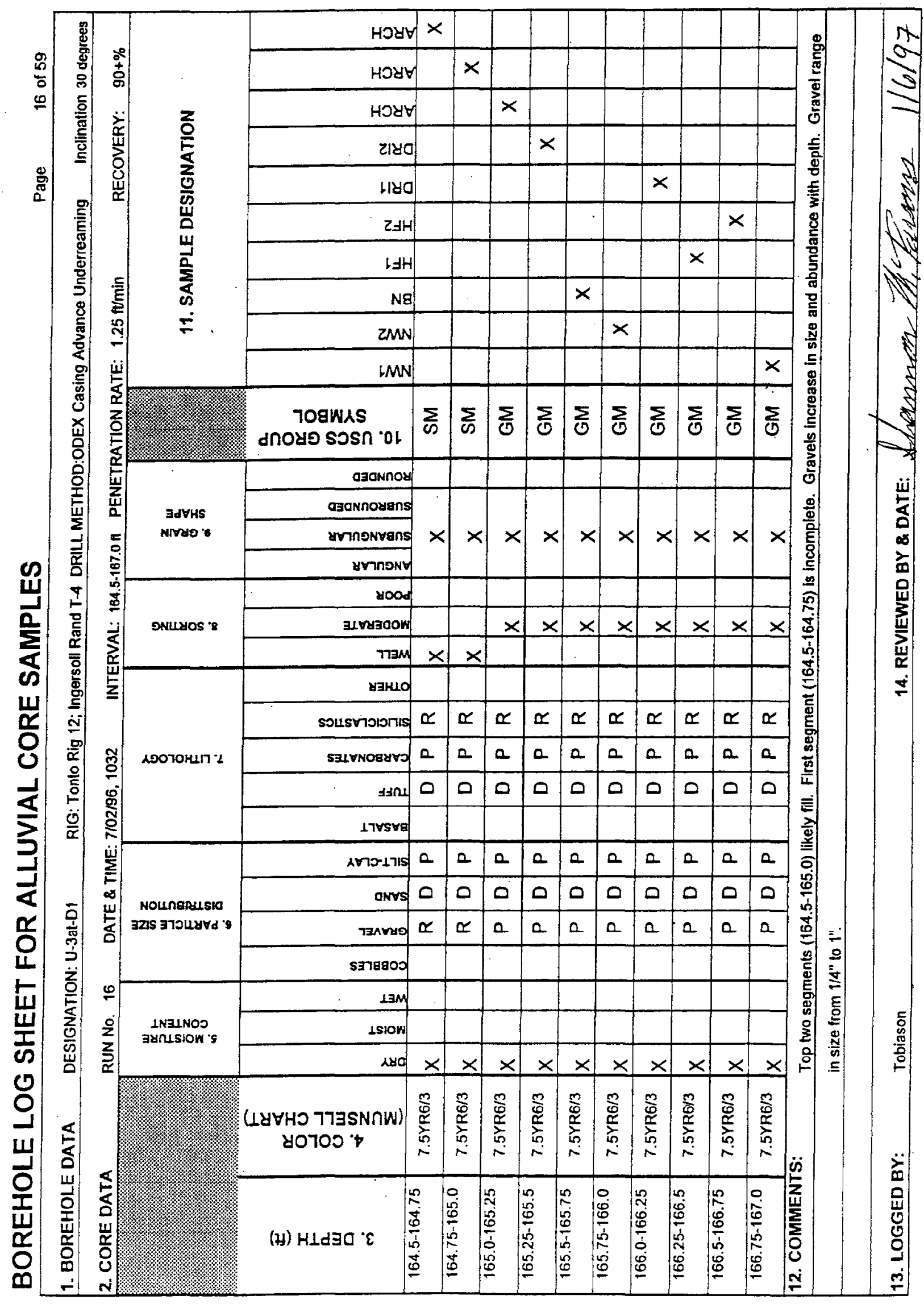




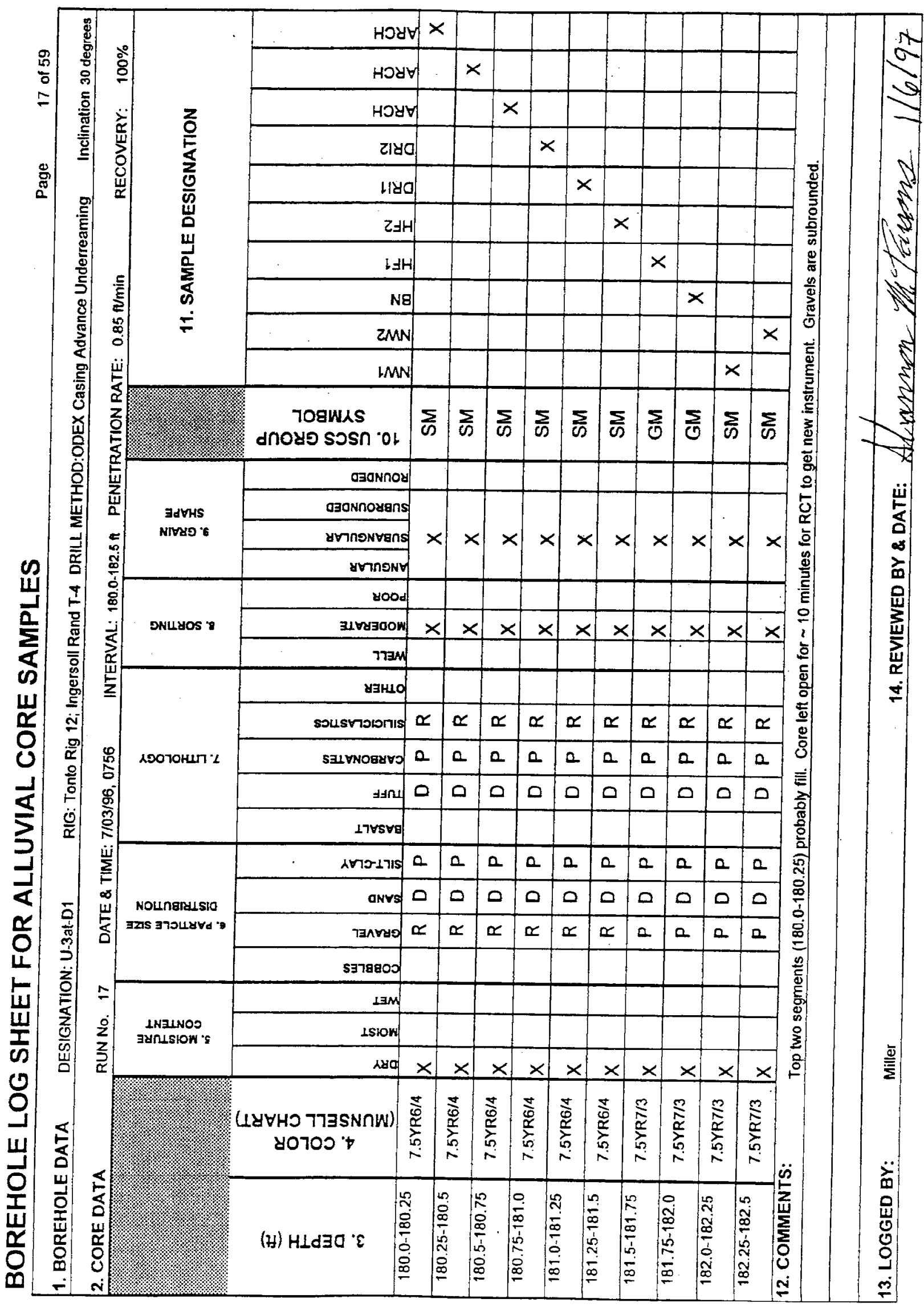




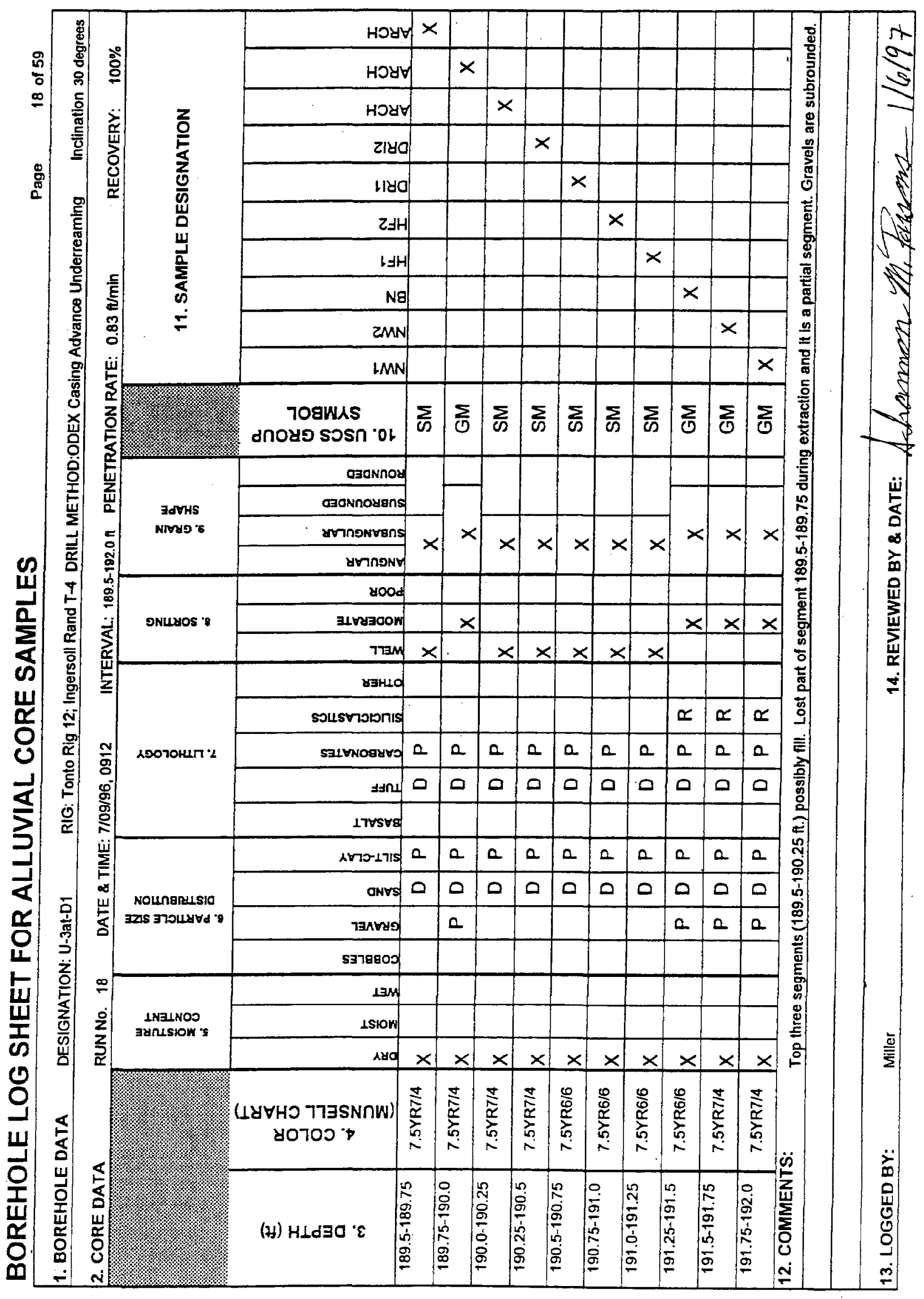




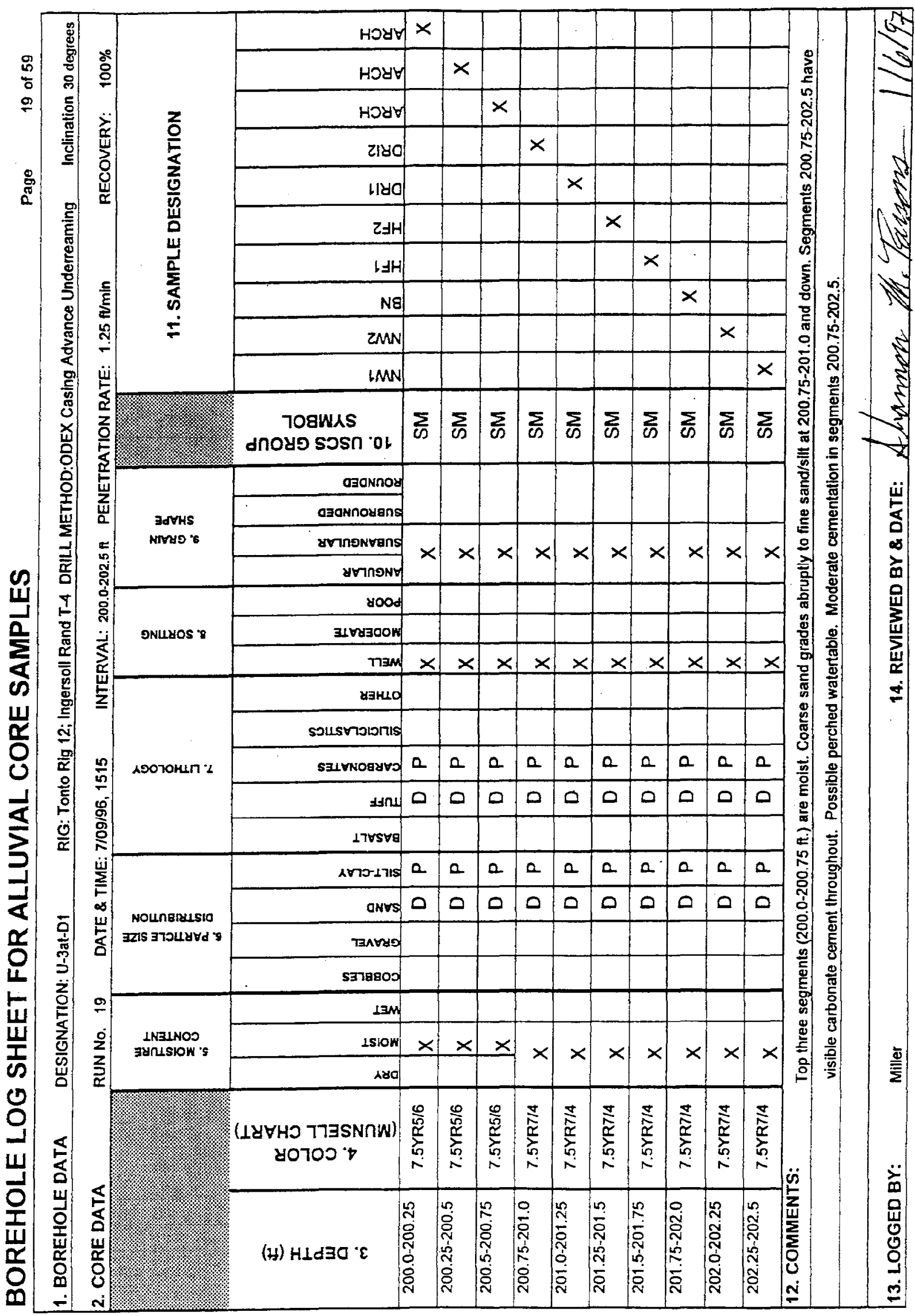




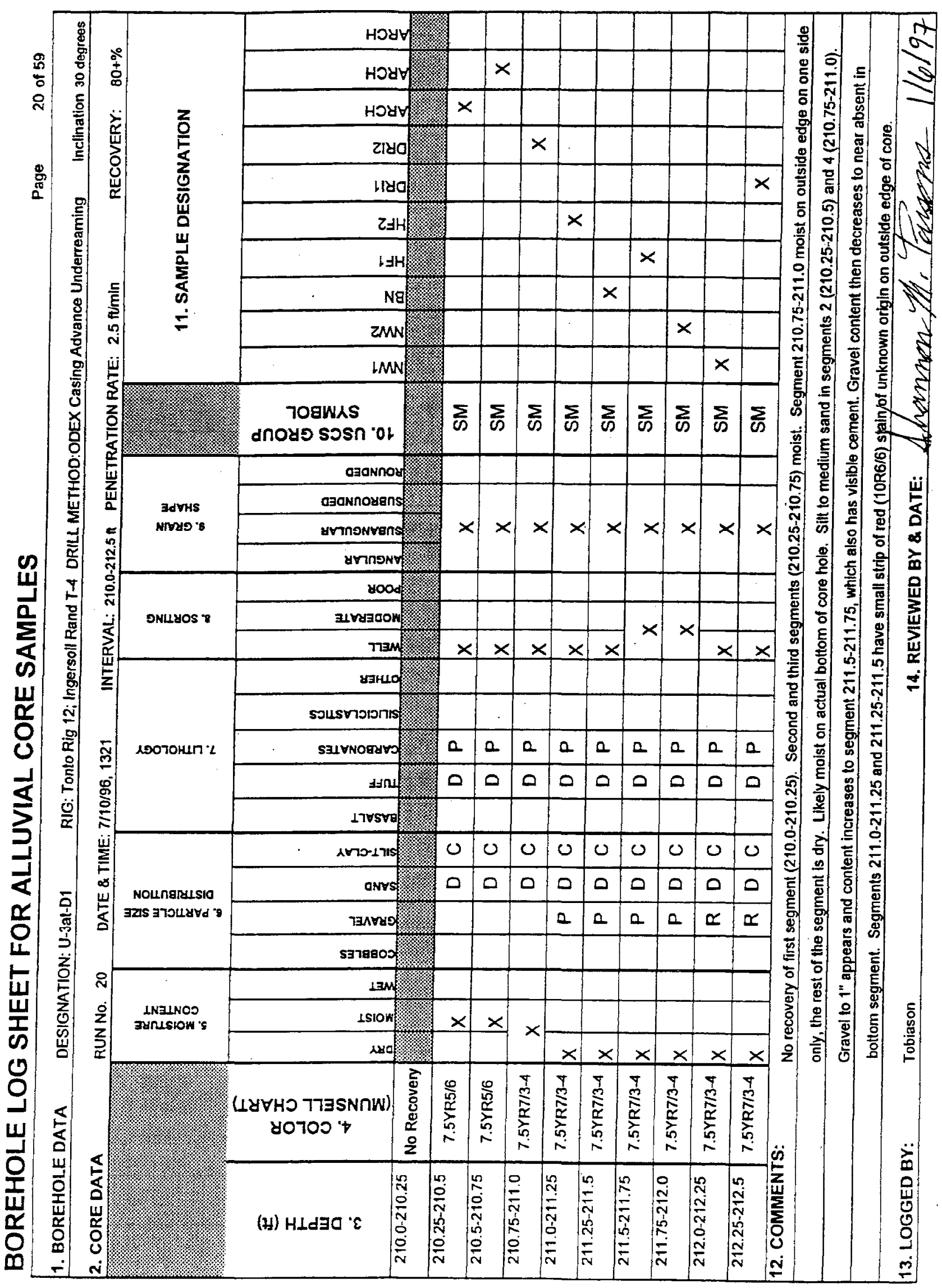




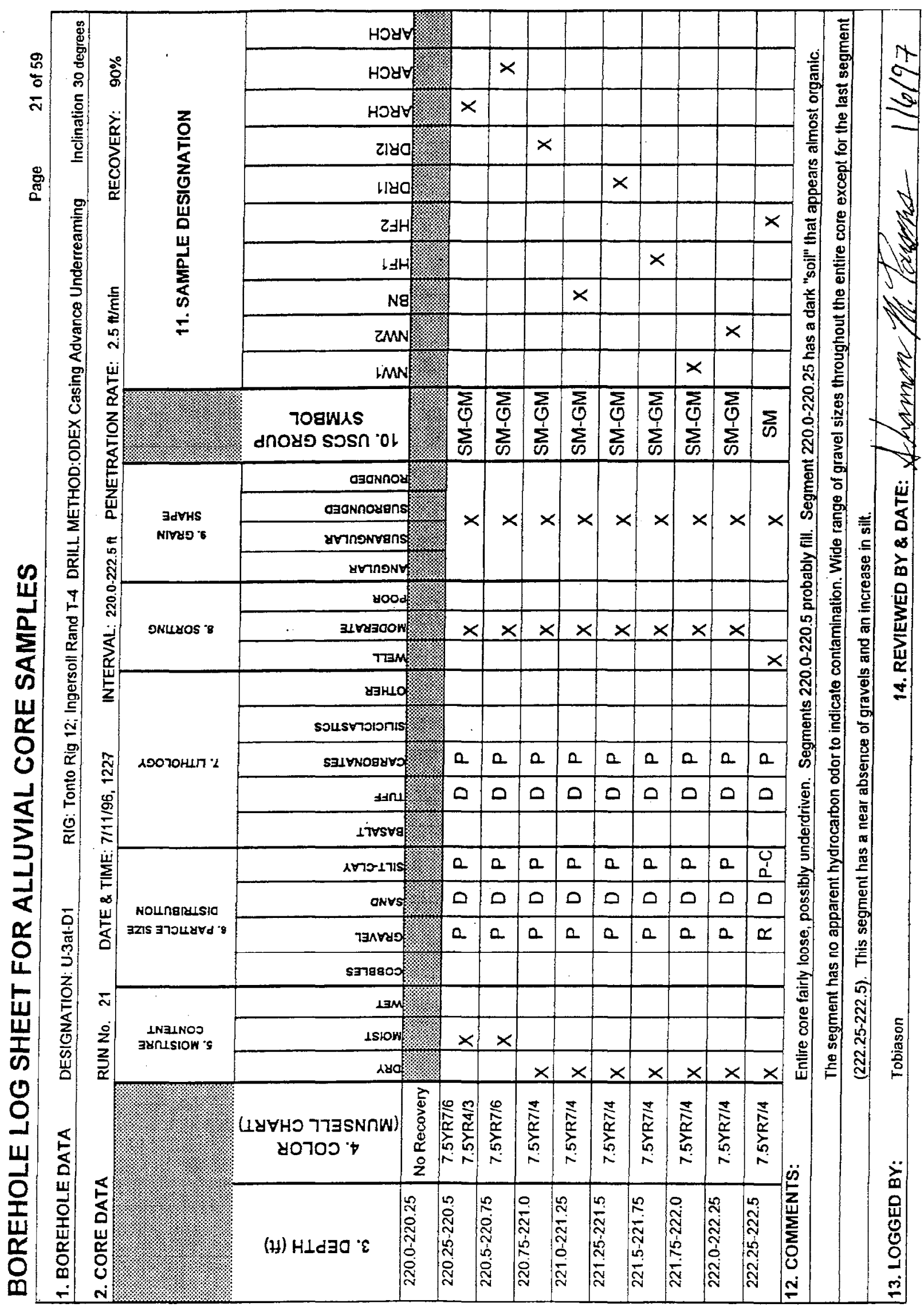




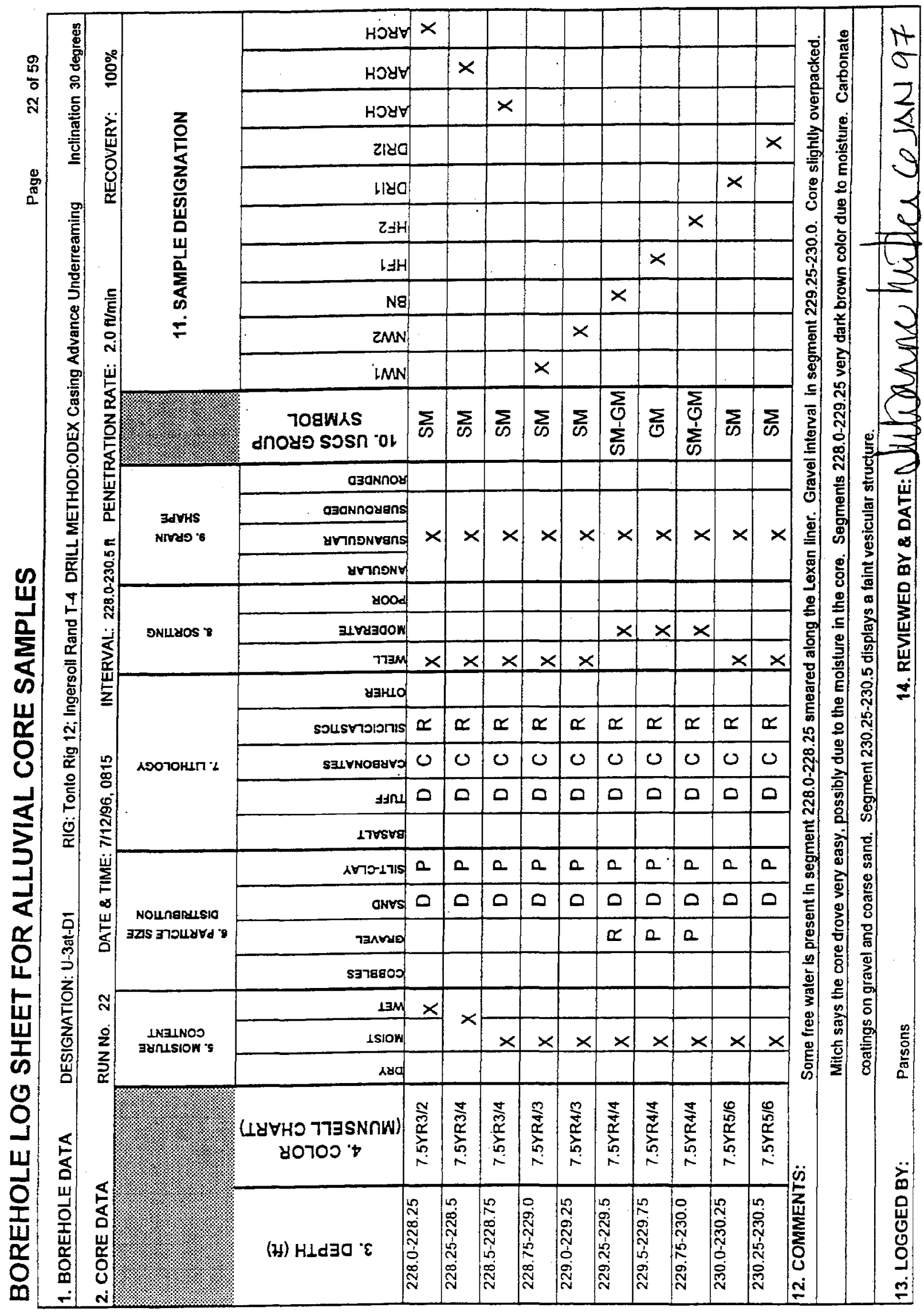




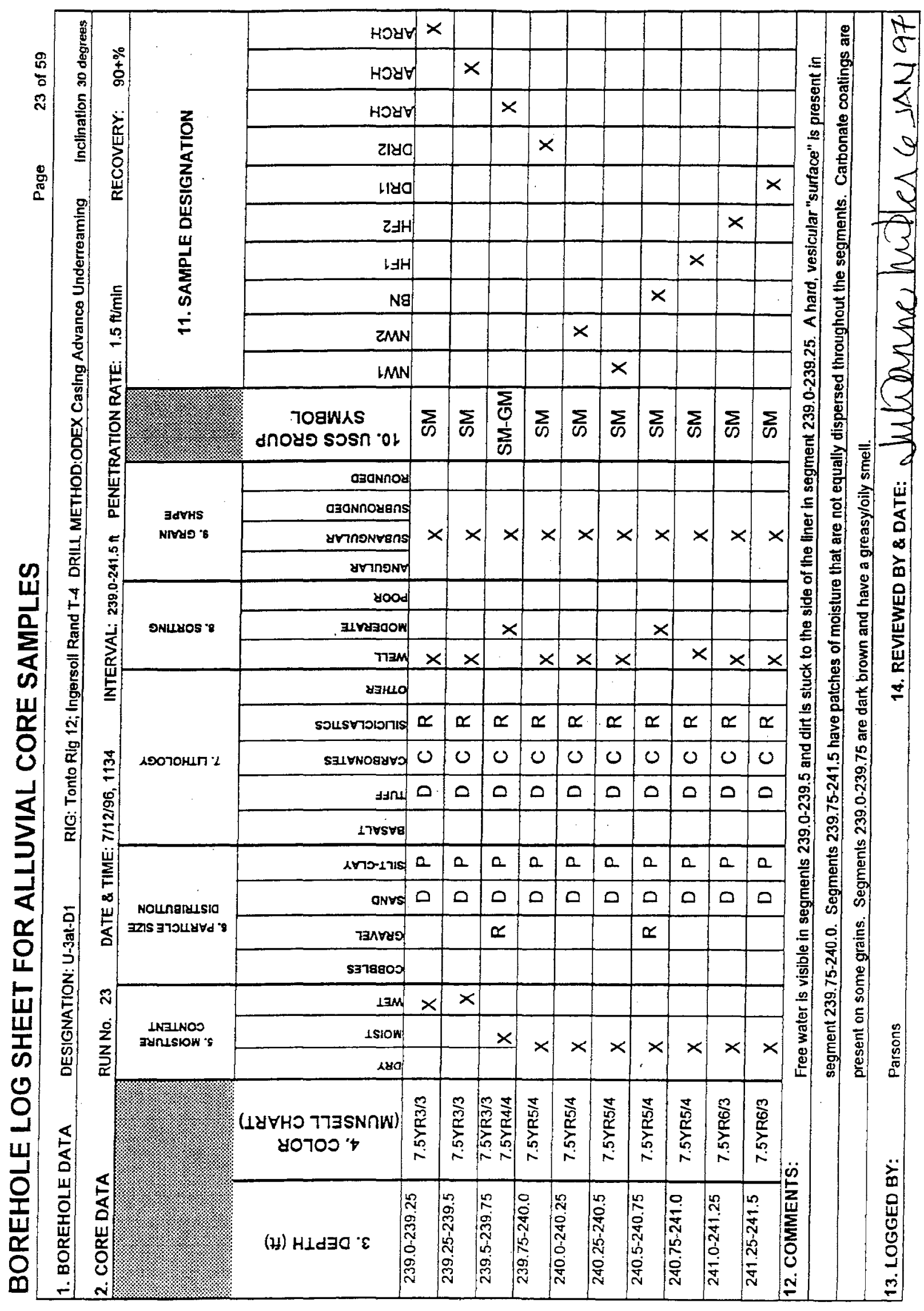




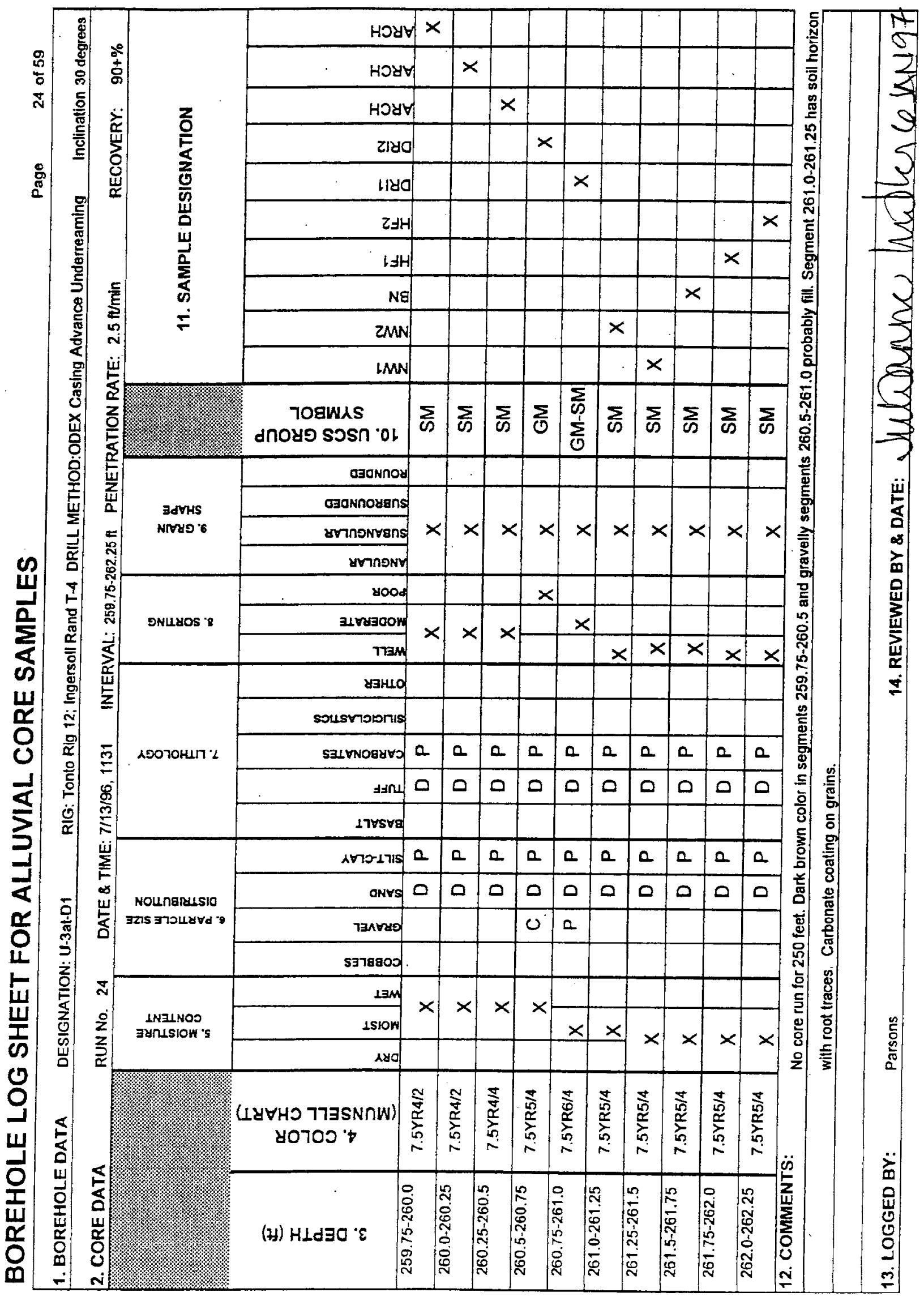




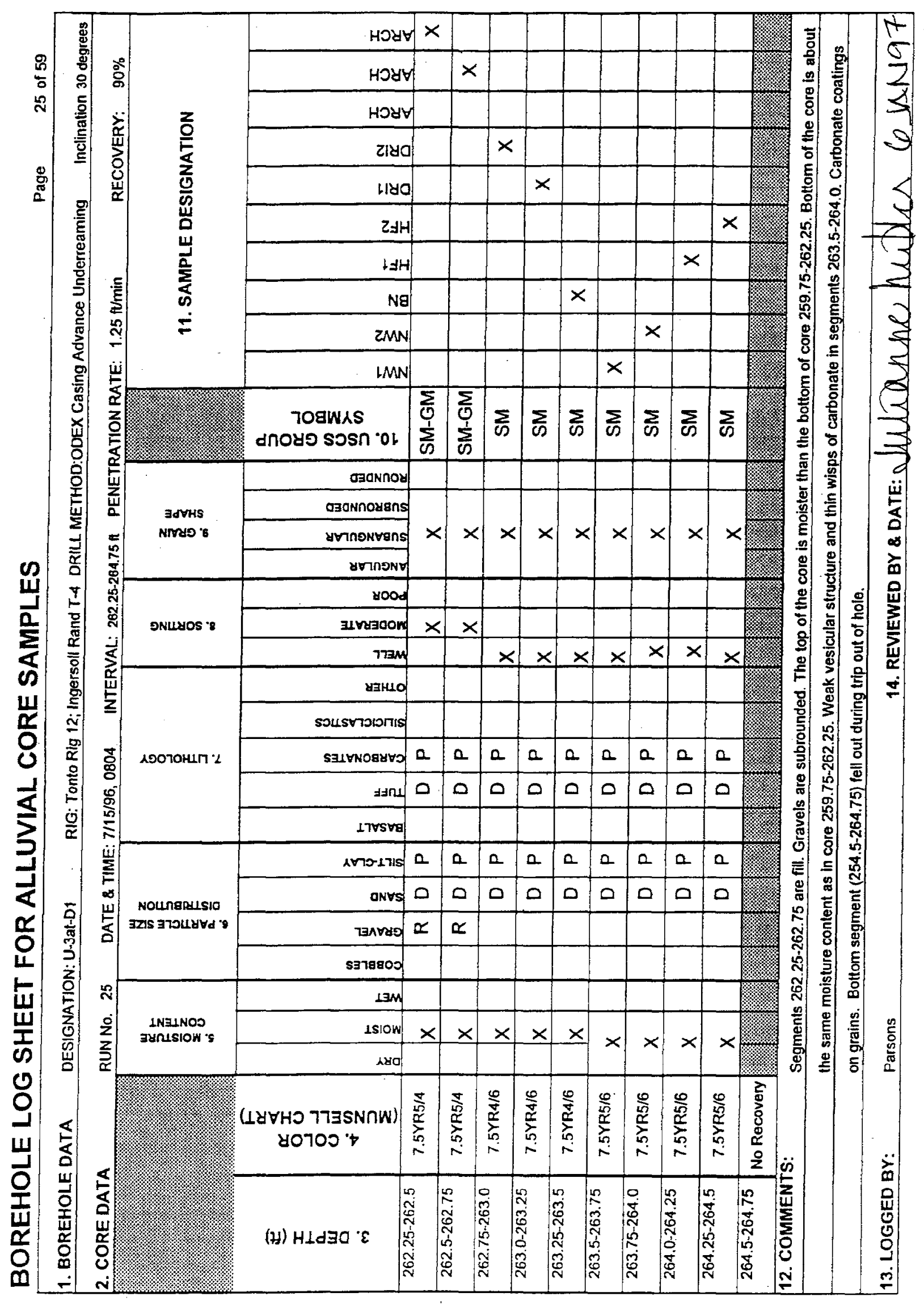




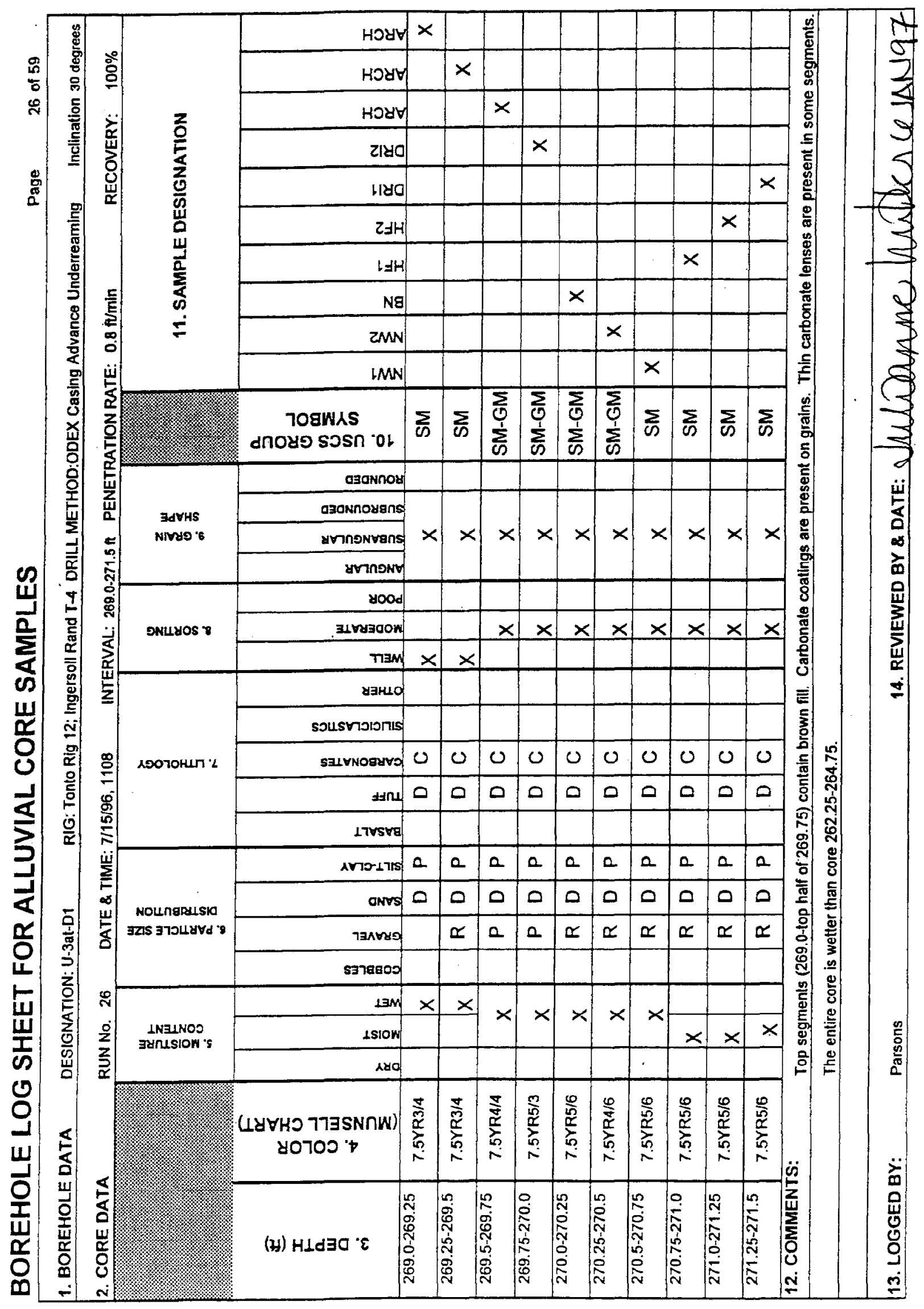




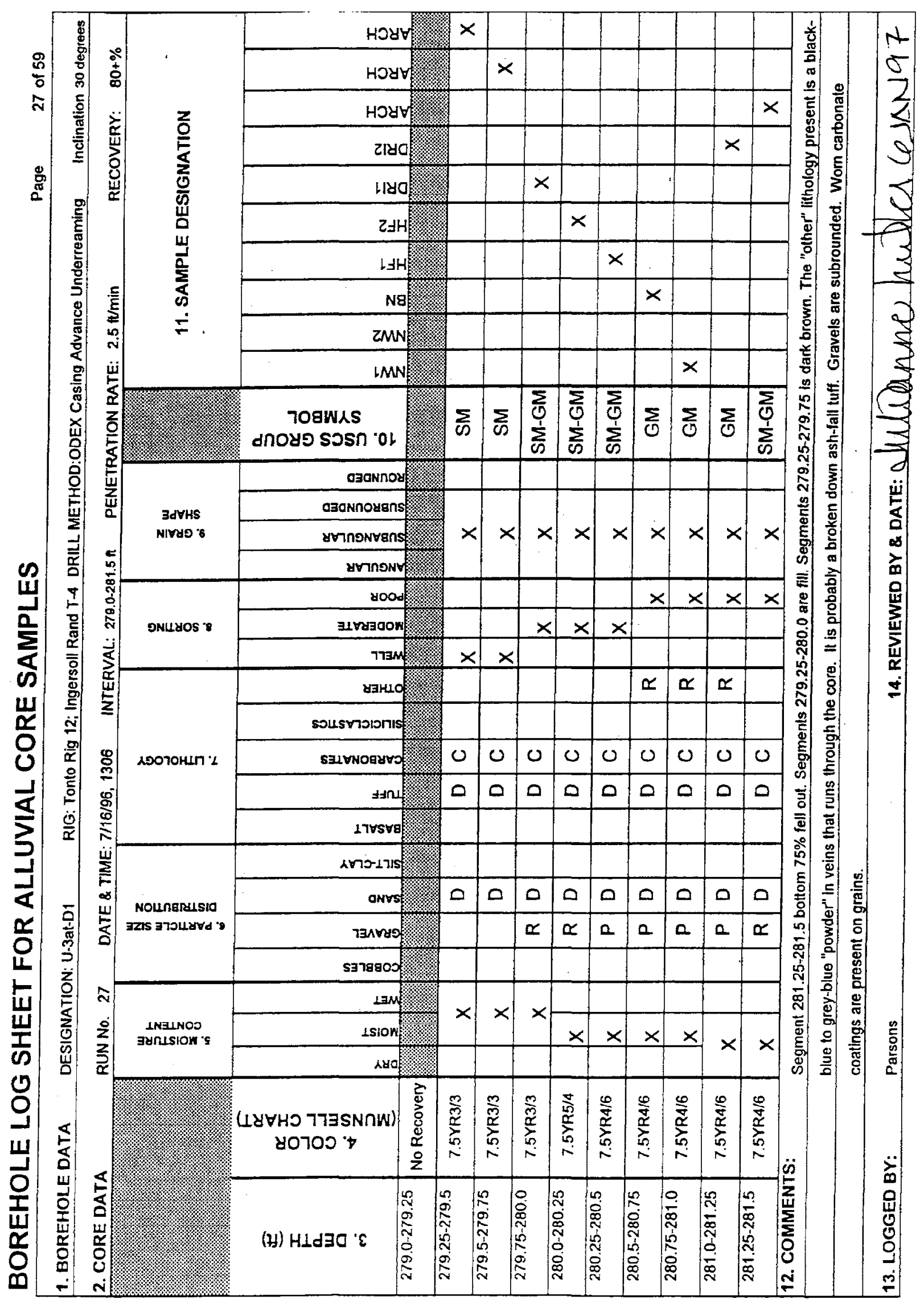




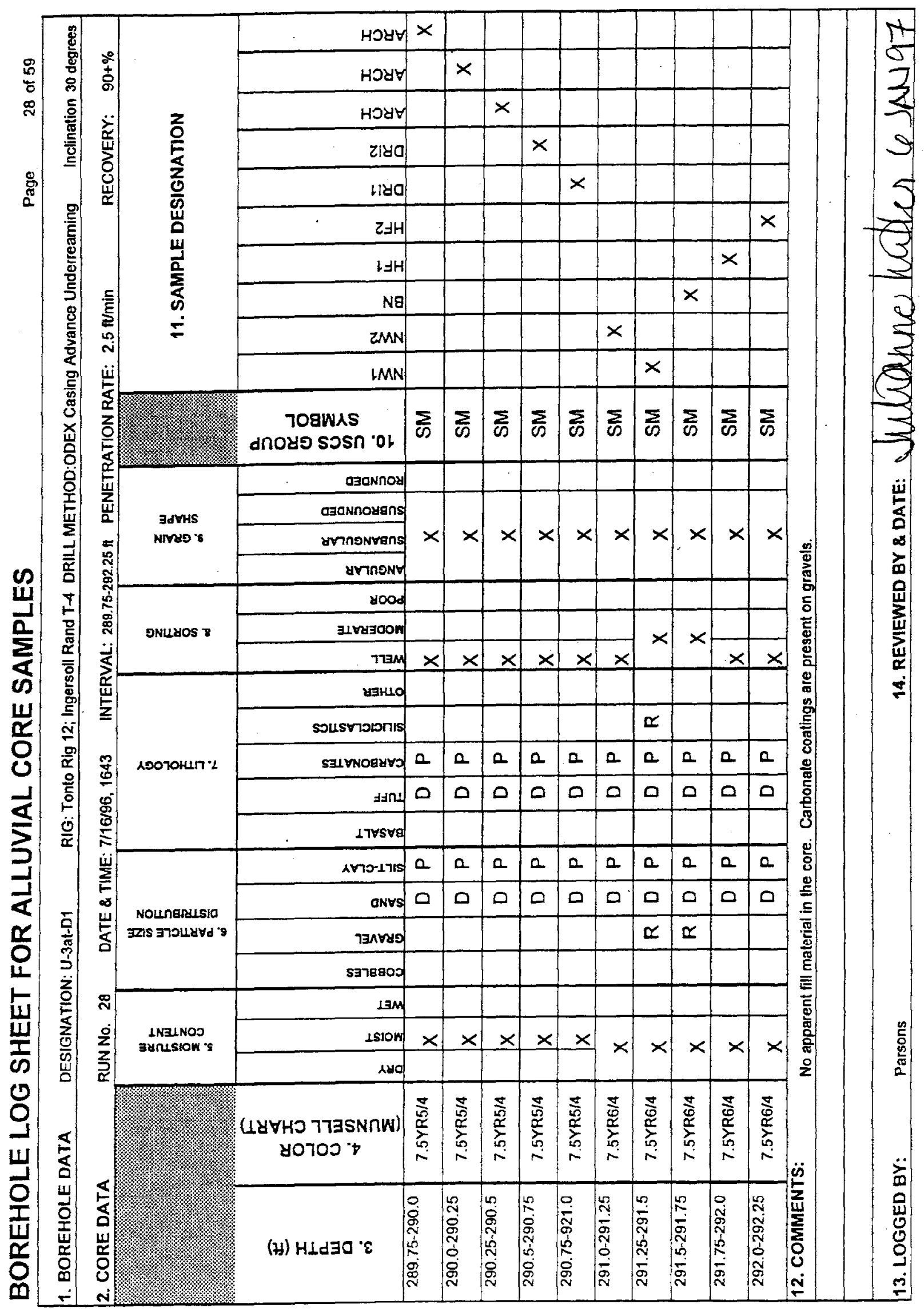




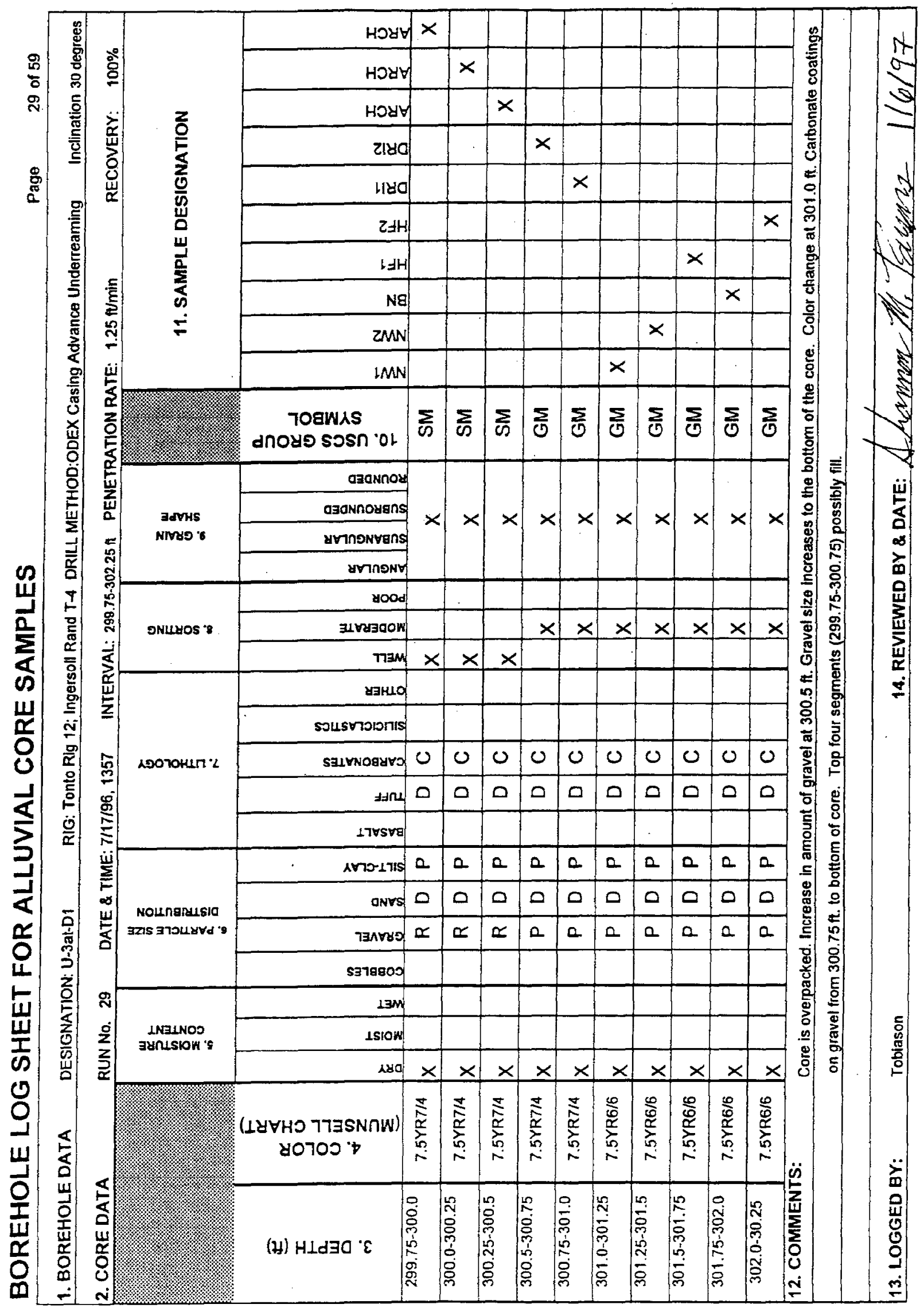




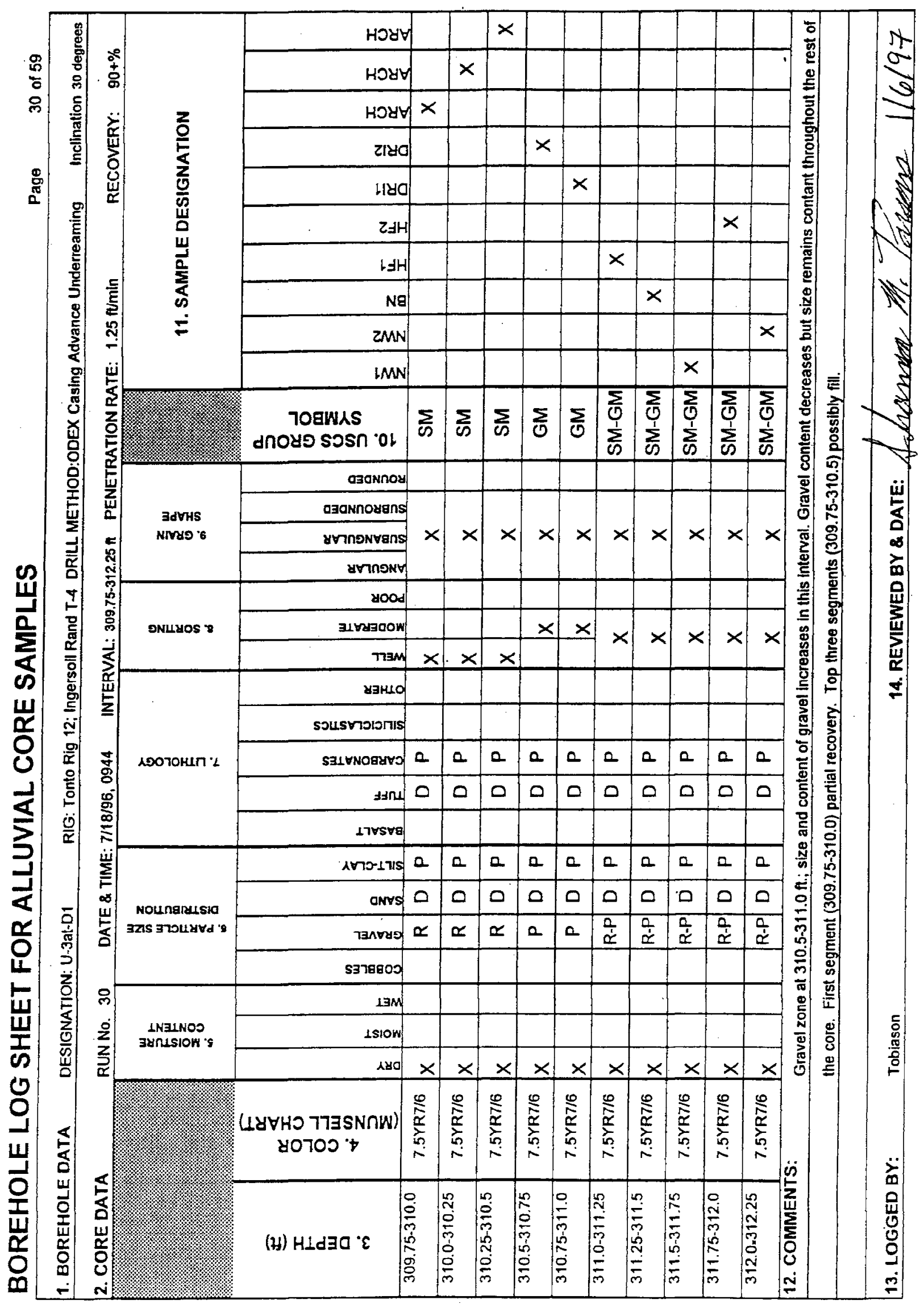




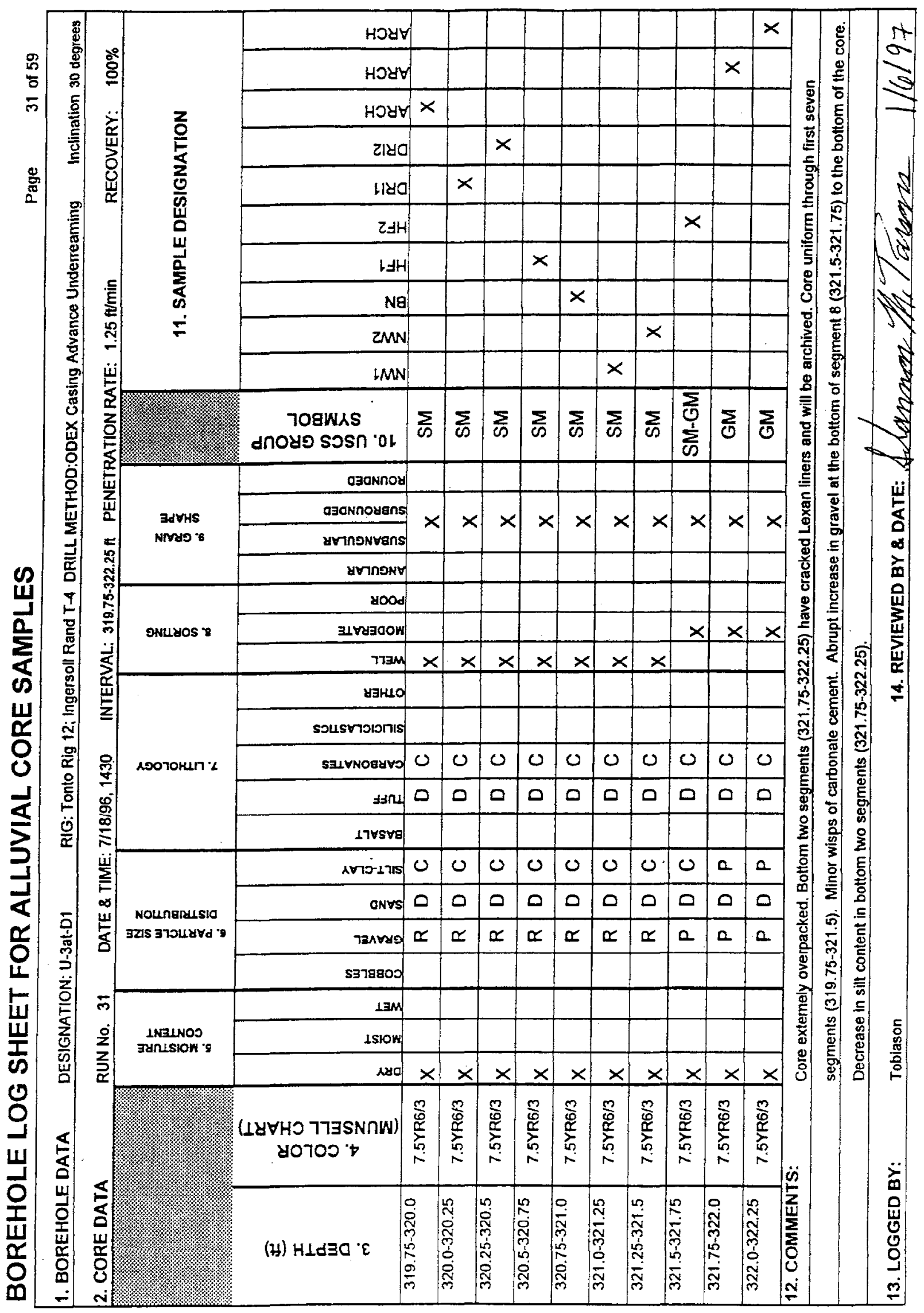




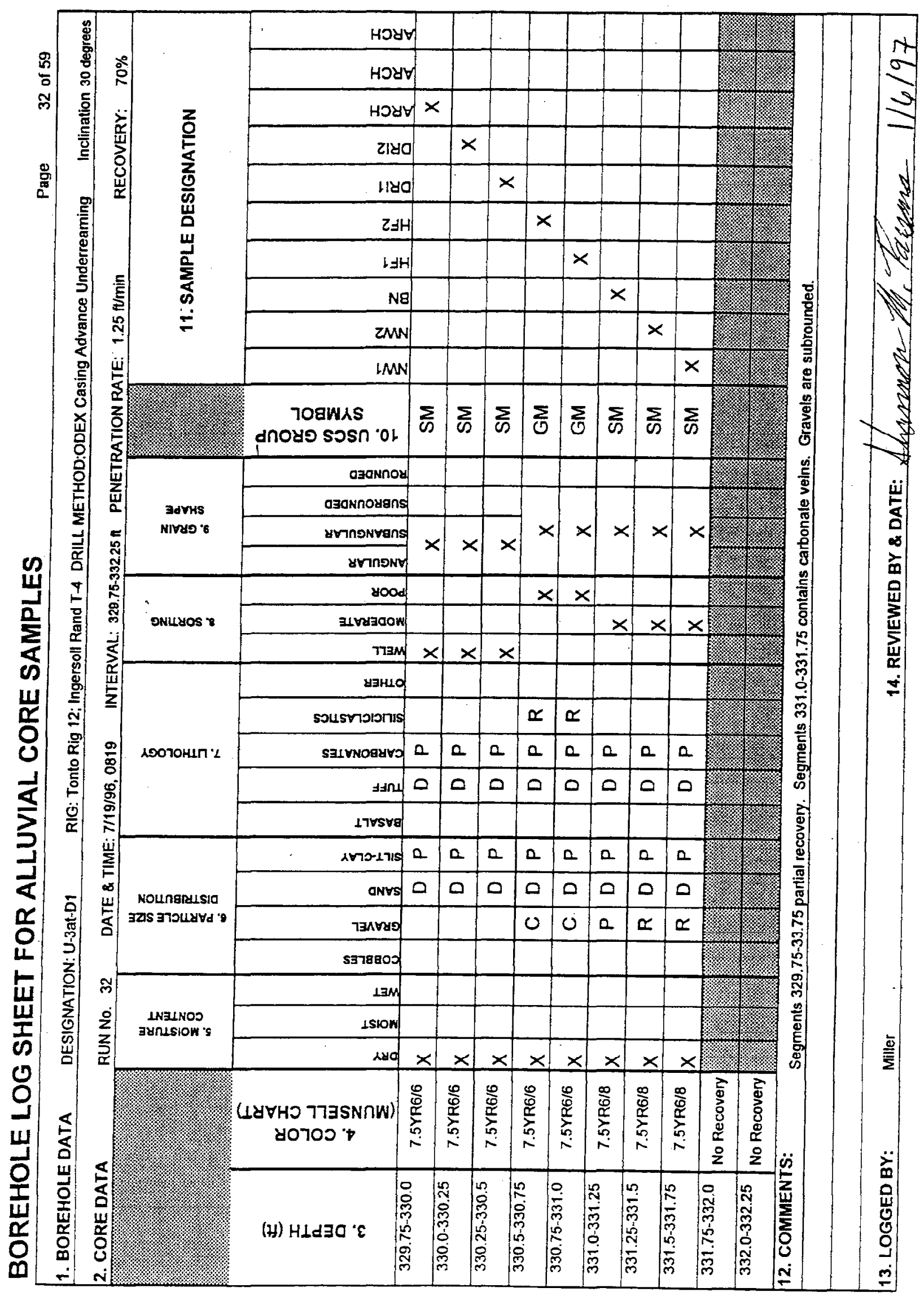




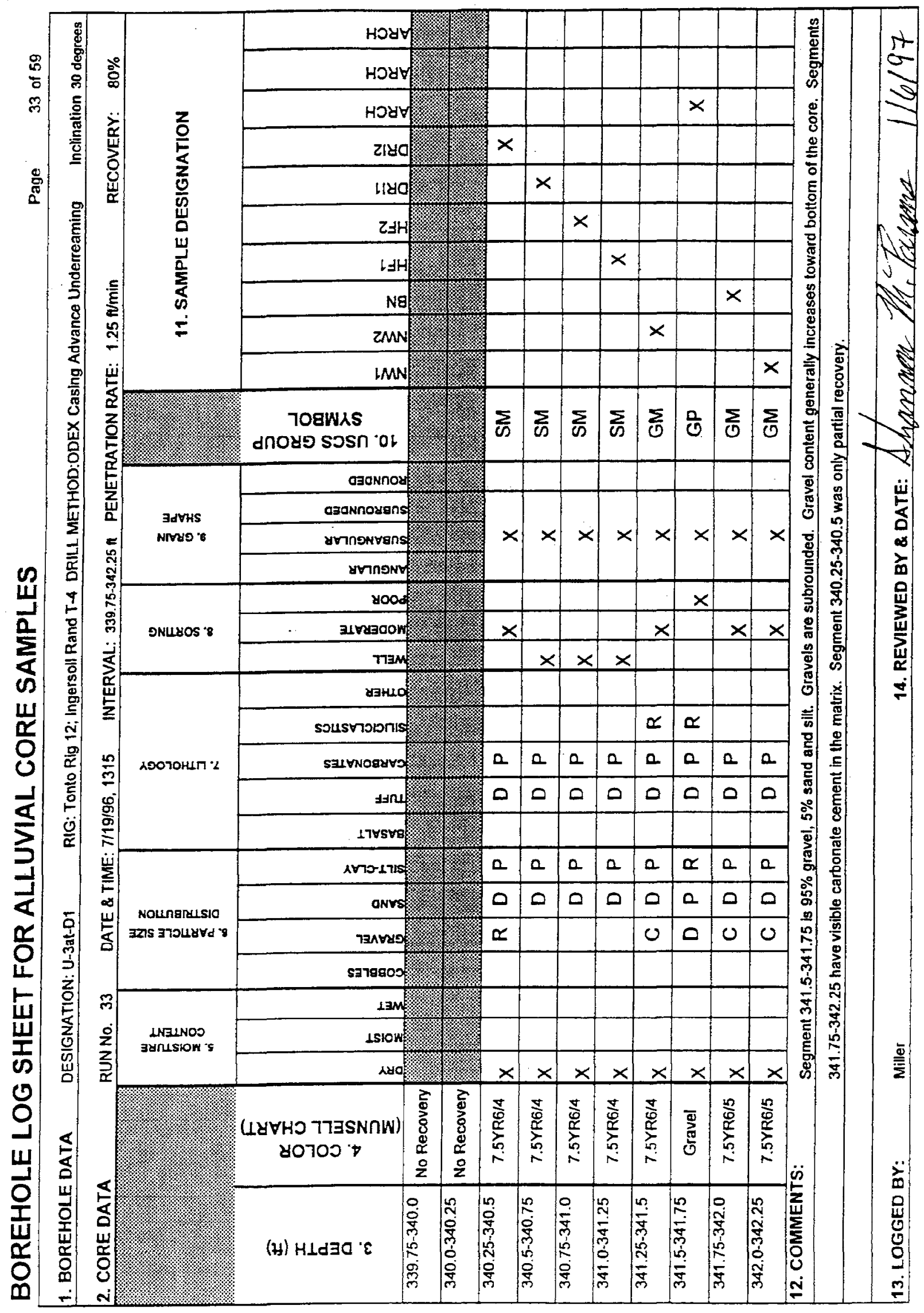




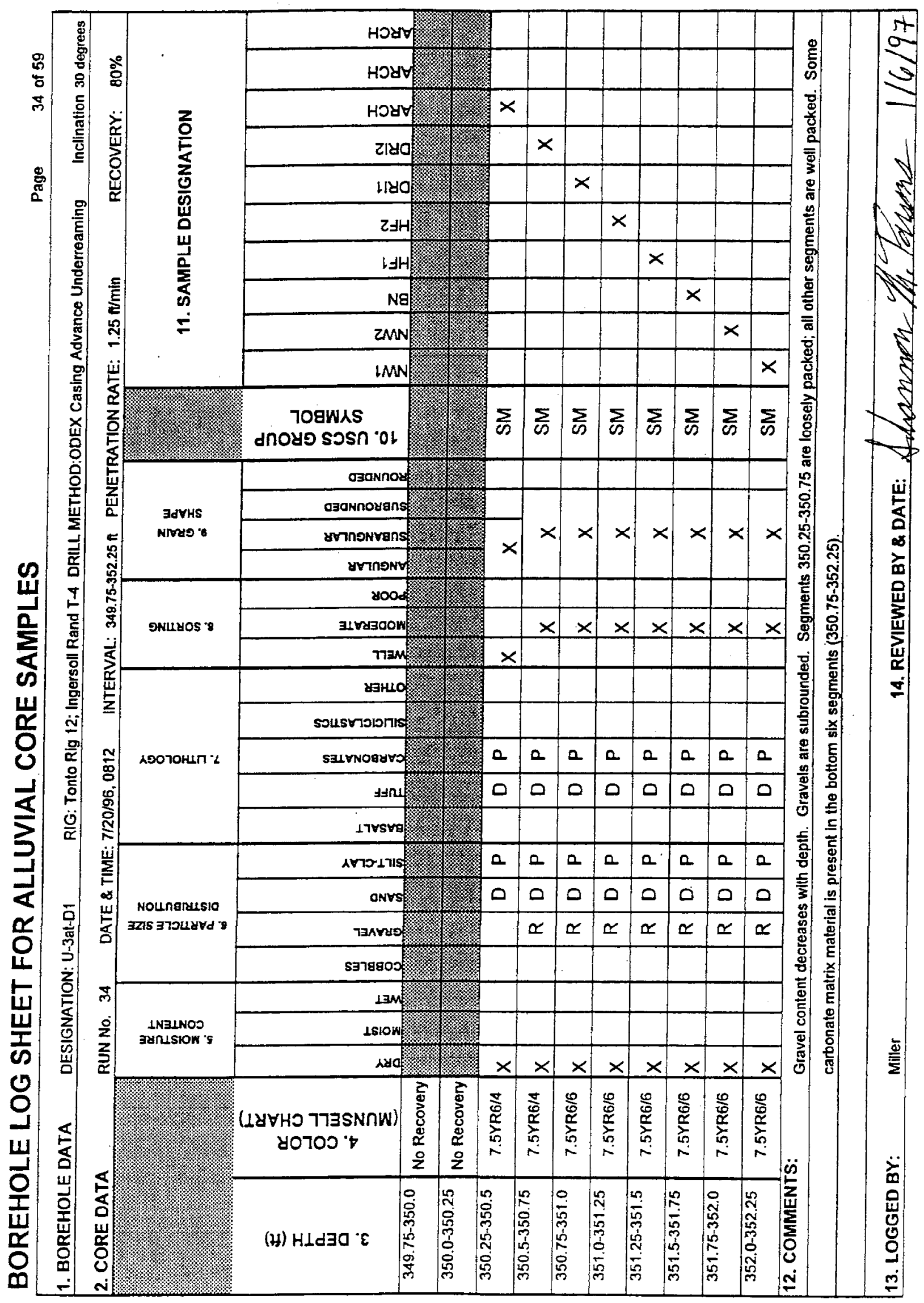




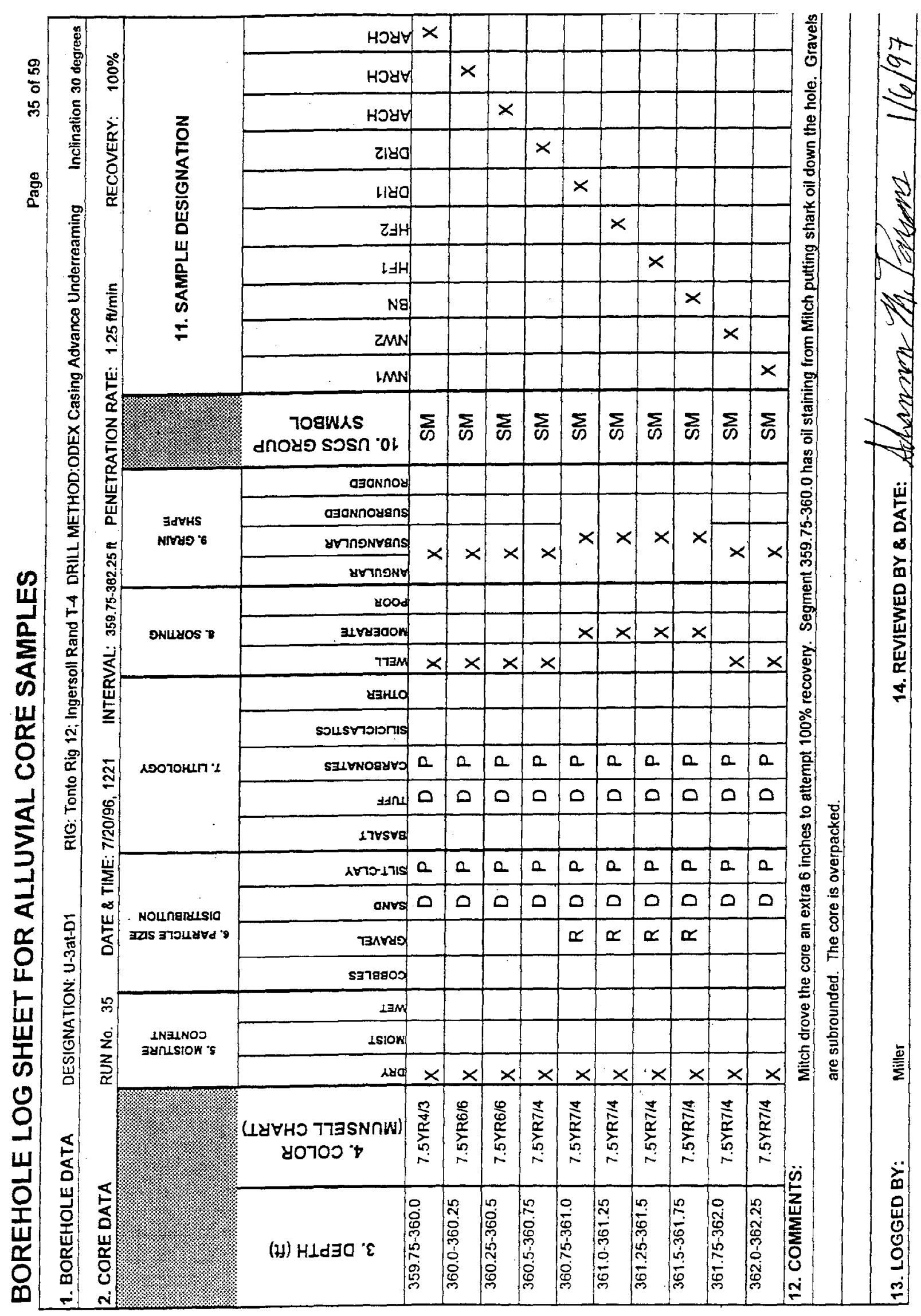




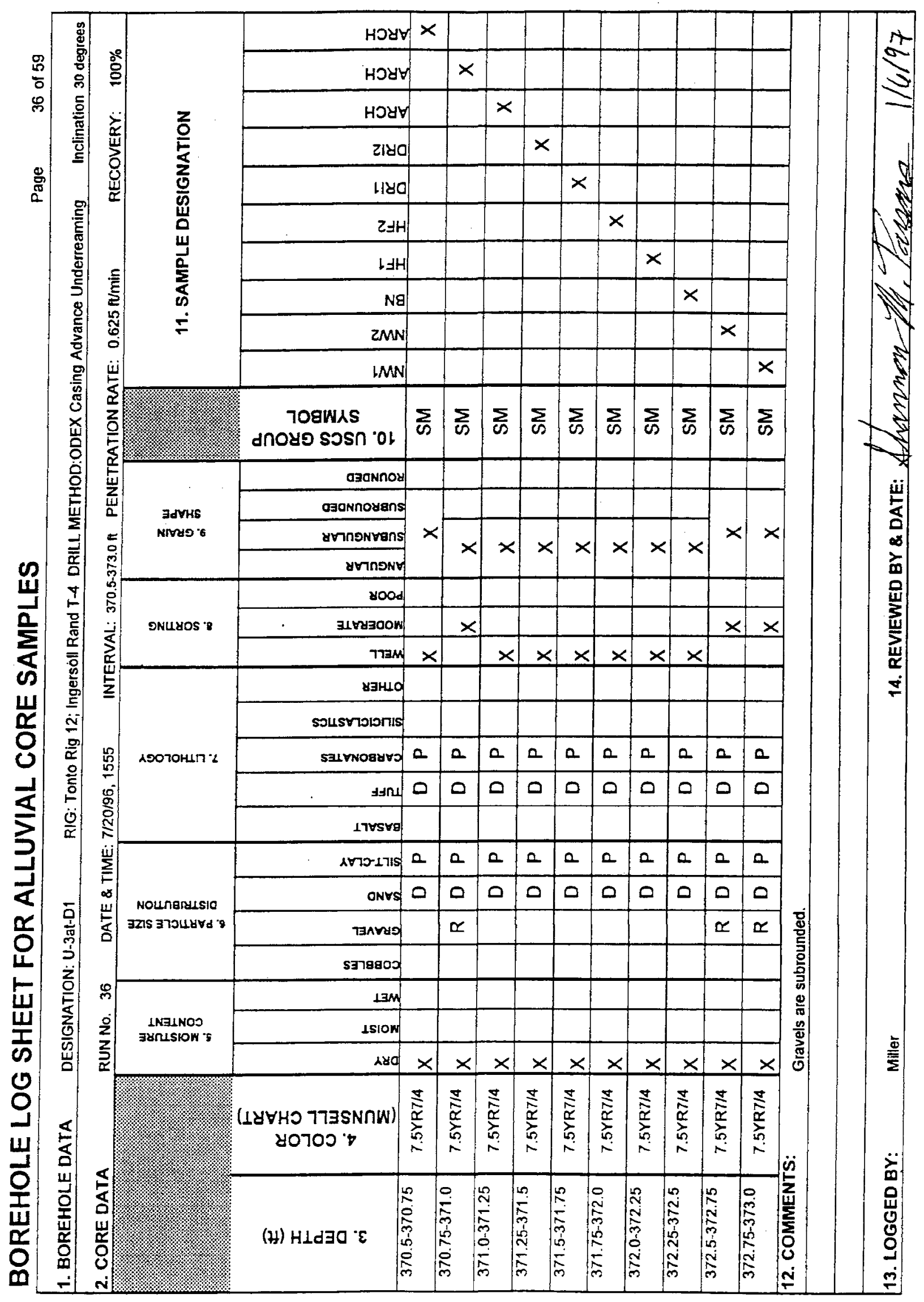




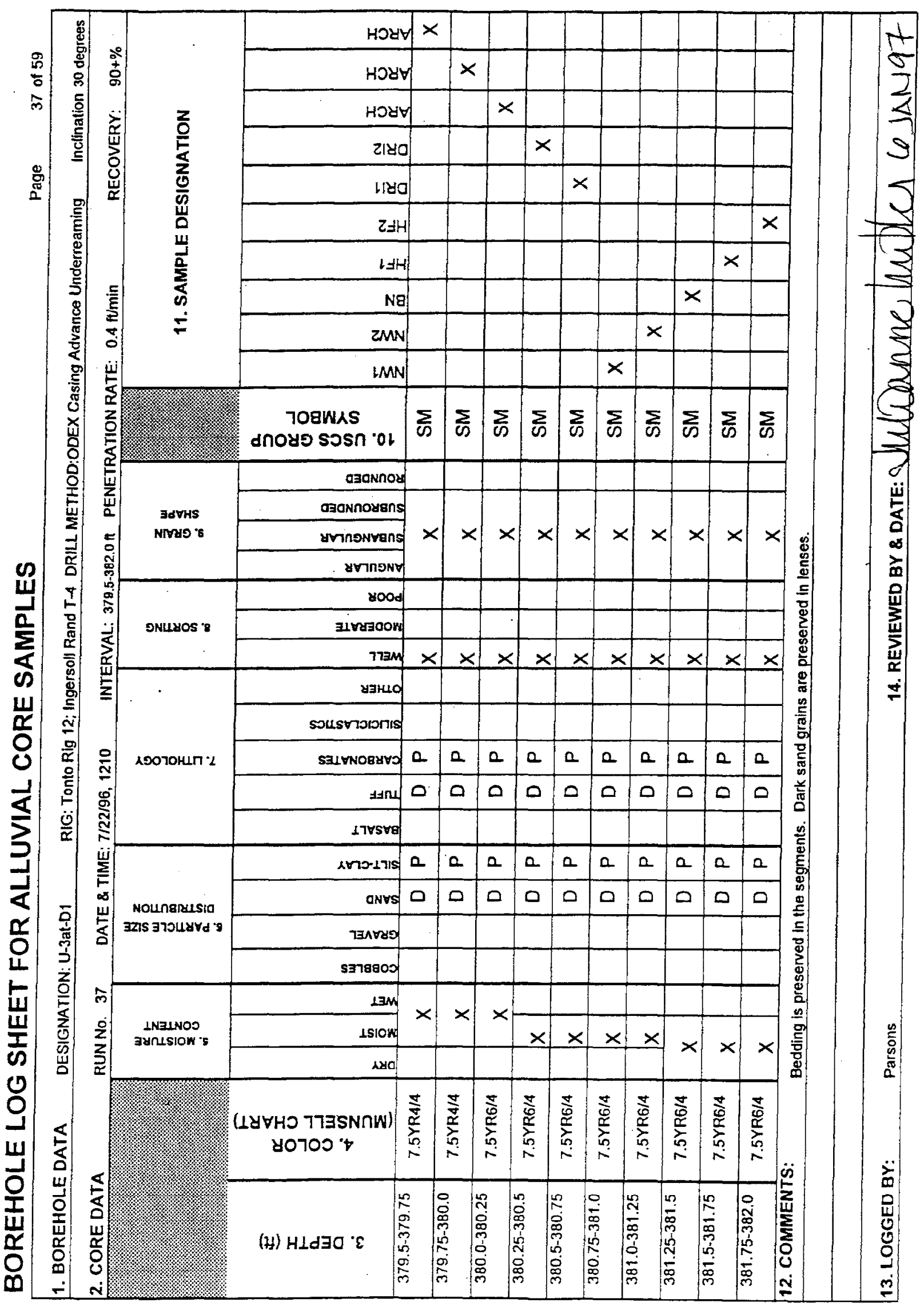




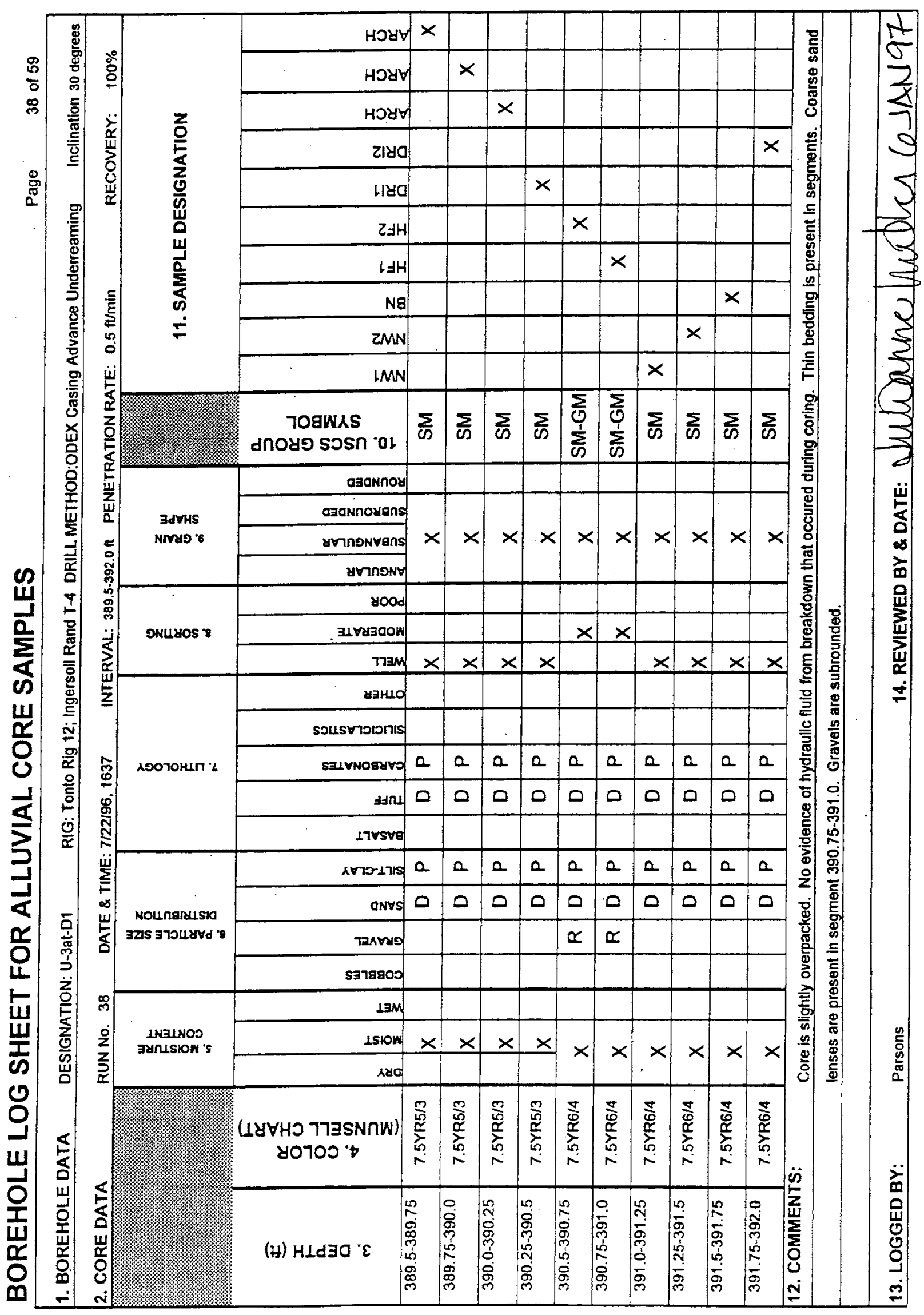




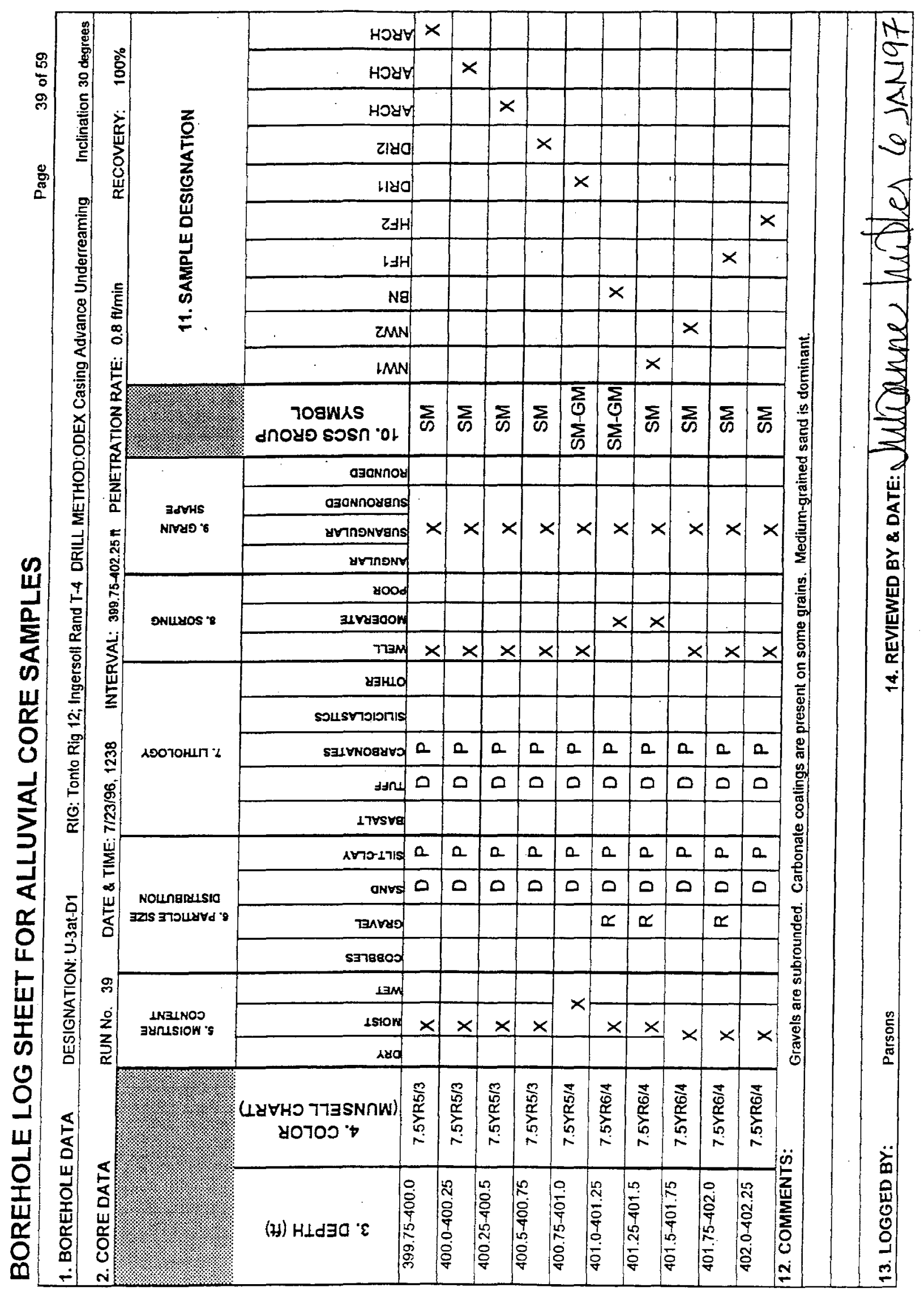




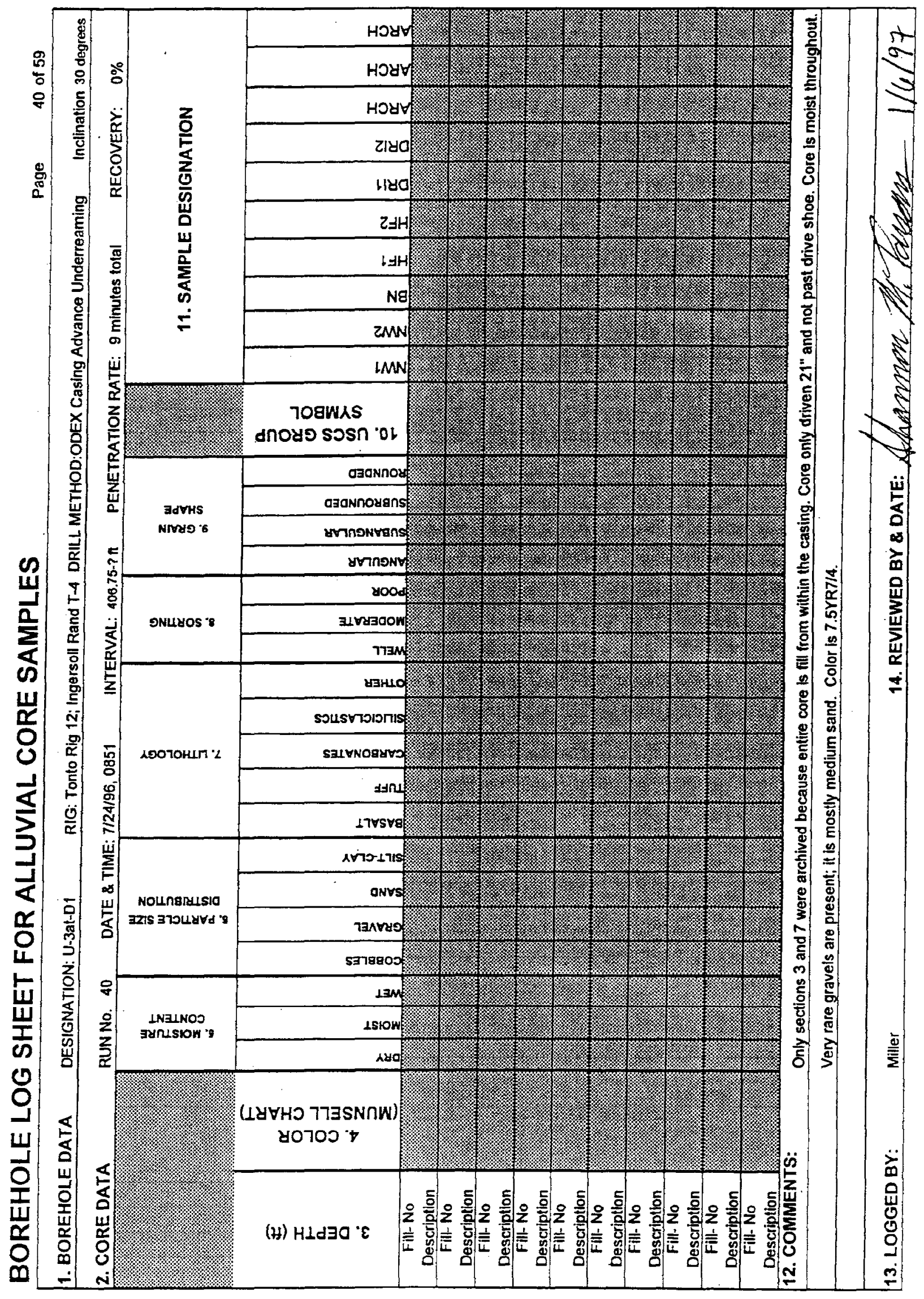




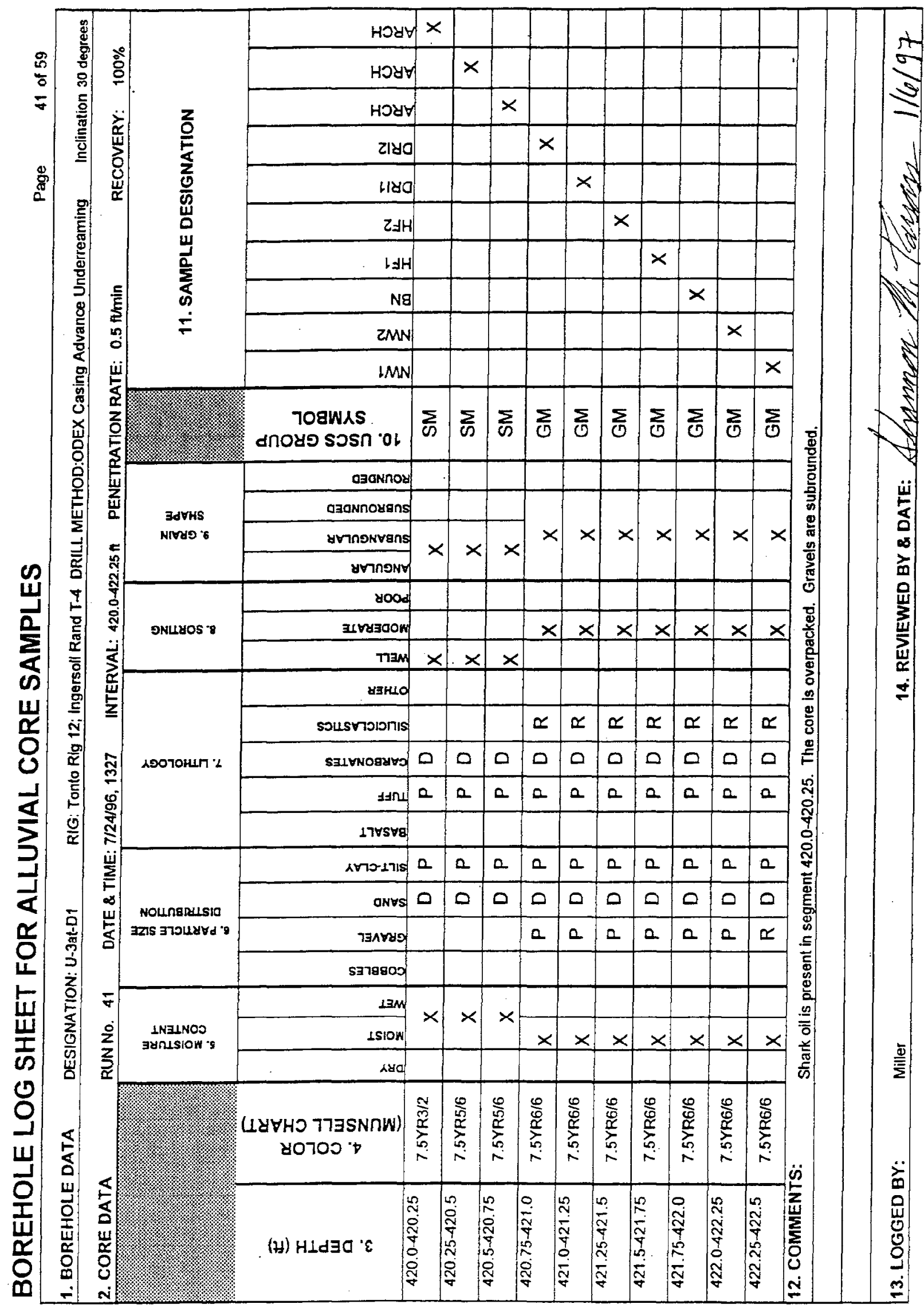




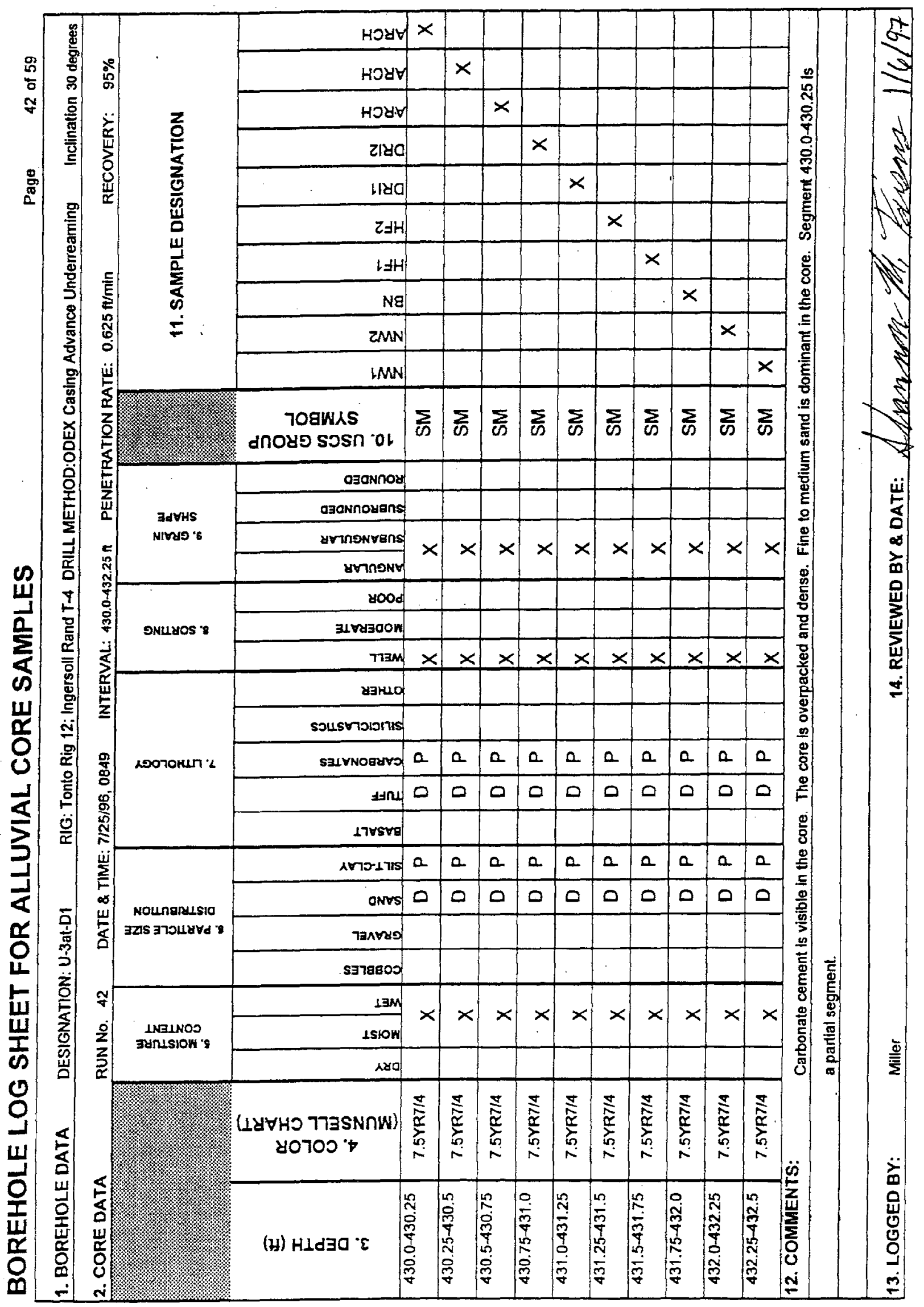




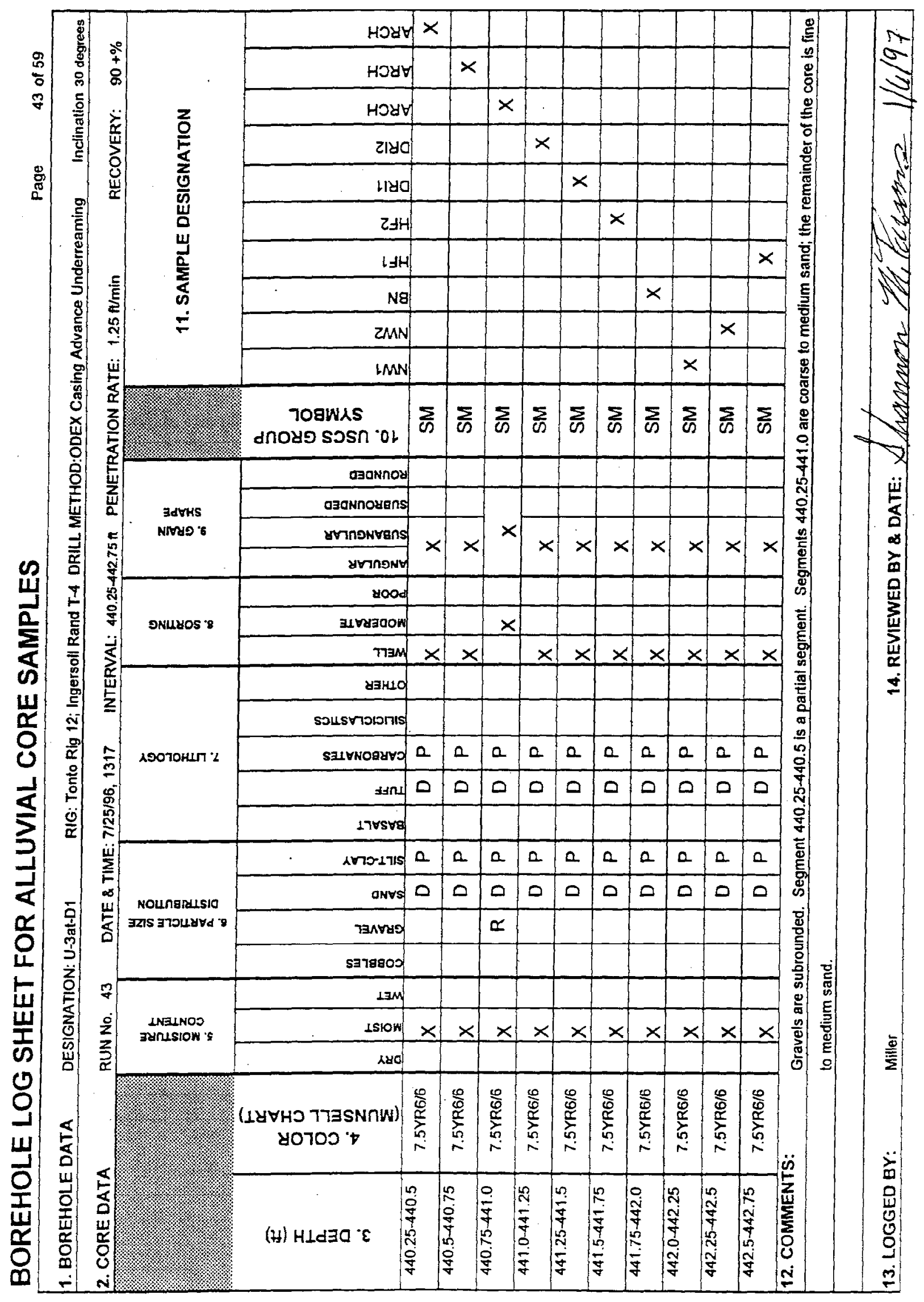




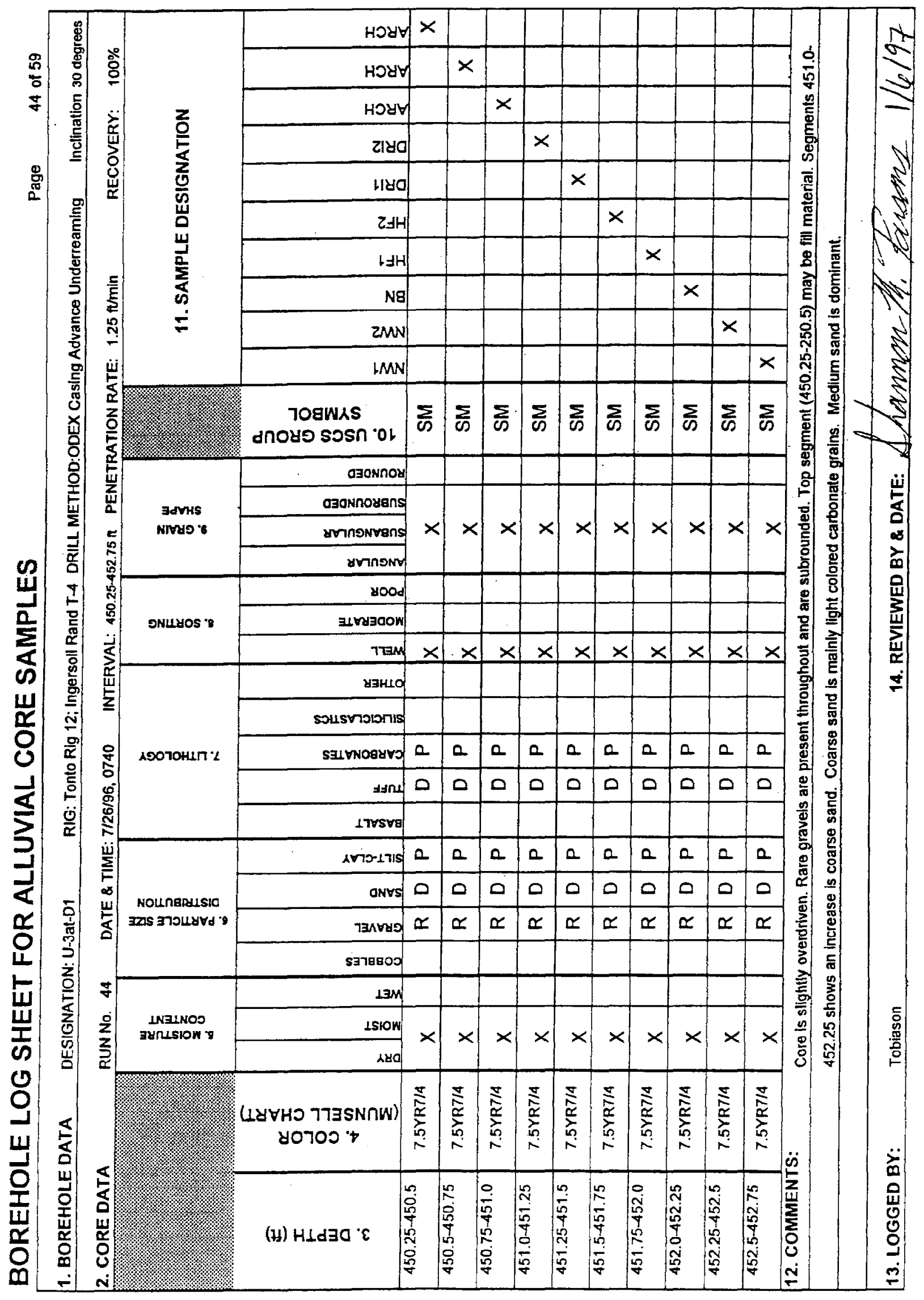




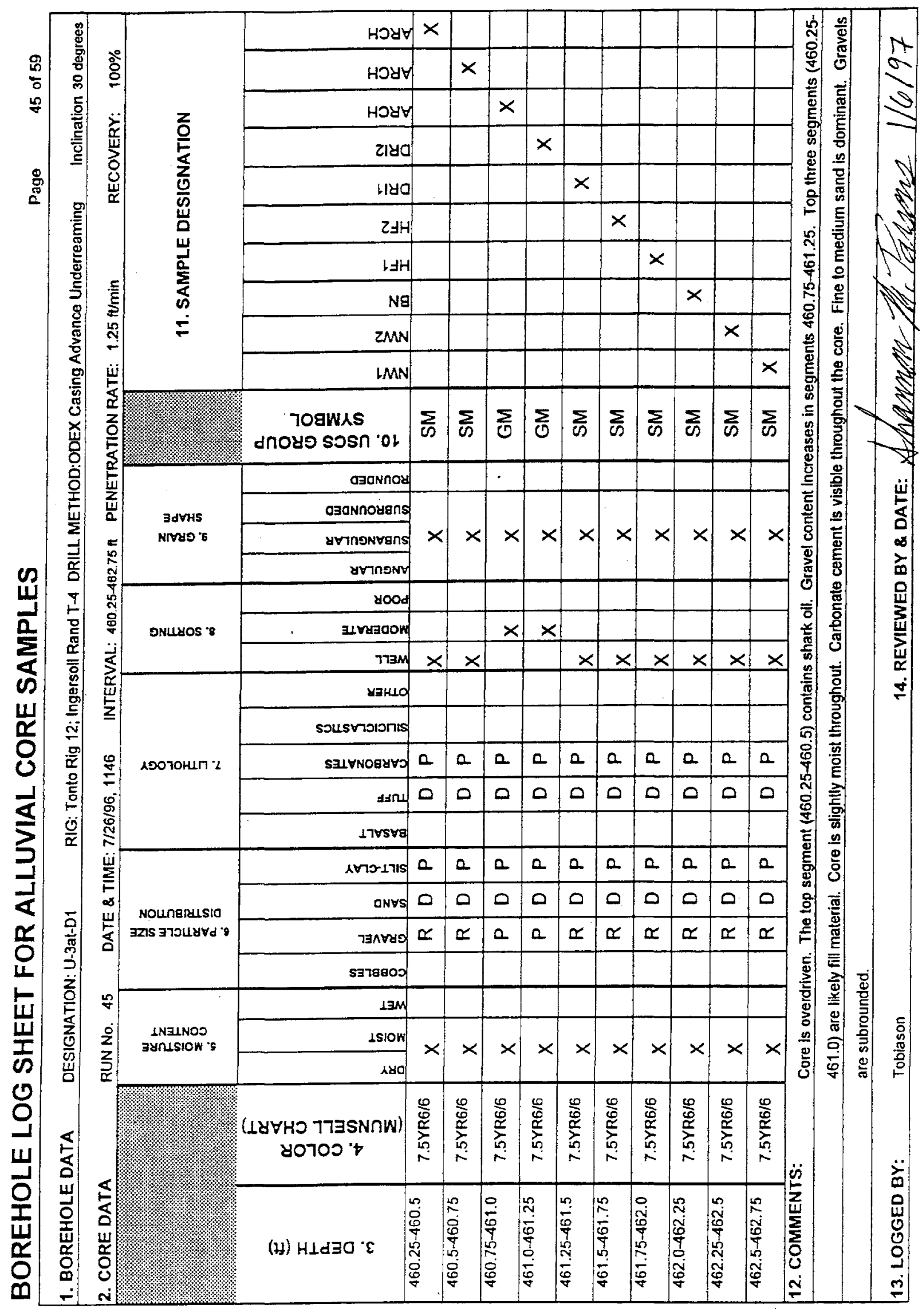




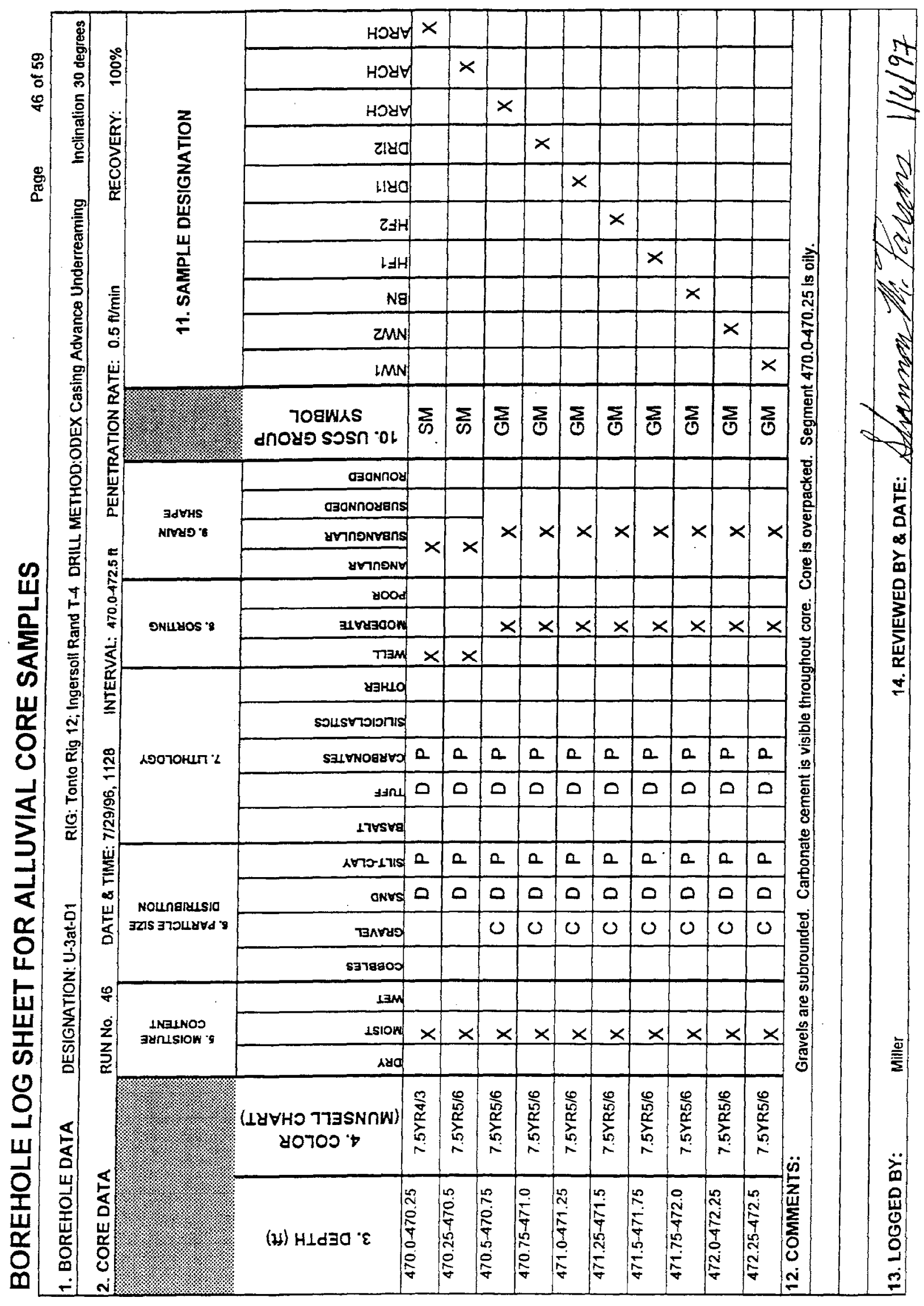

A - A6 


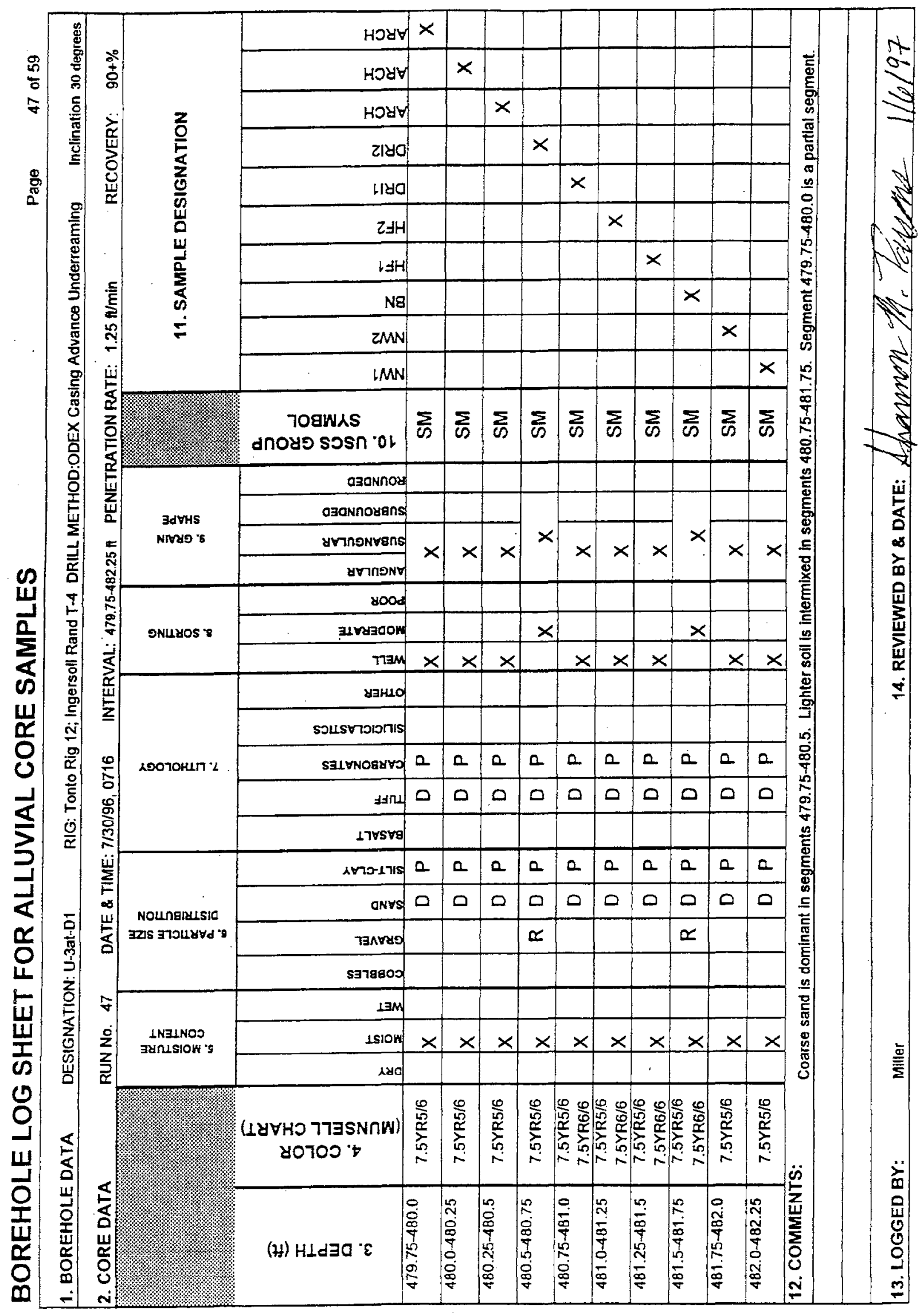




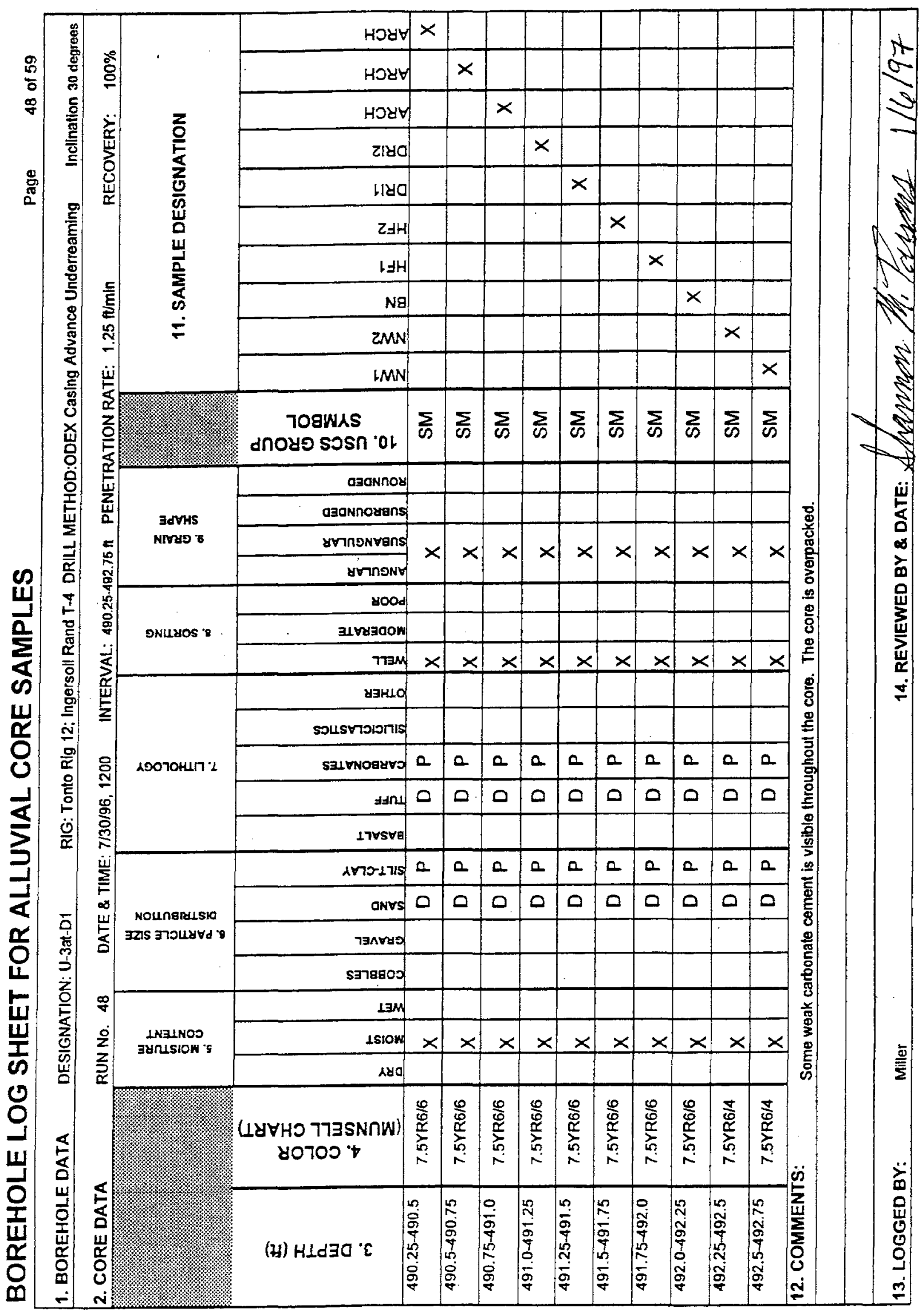




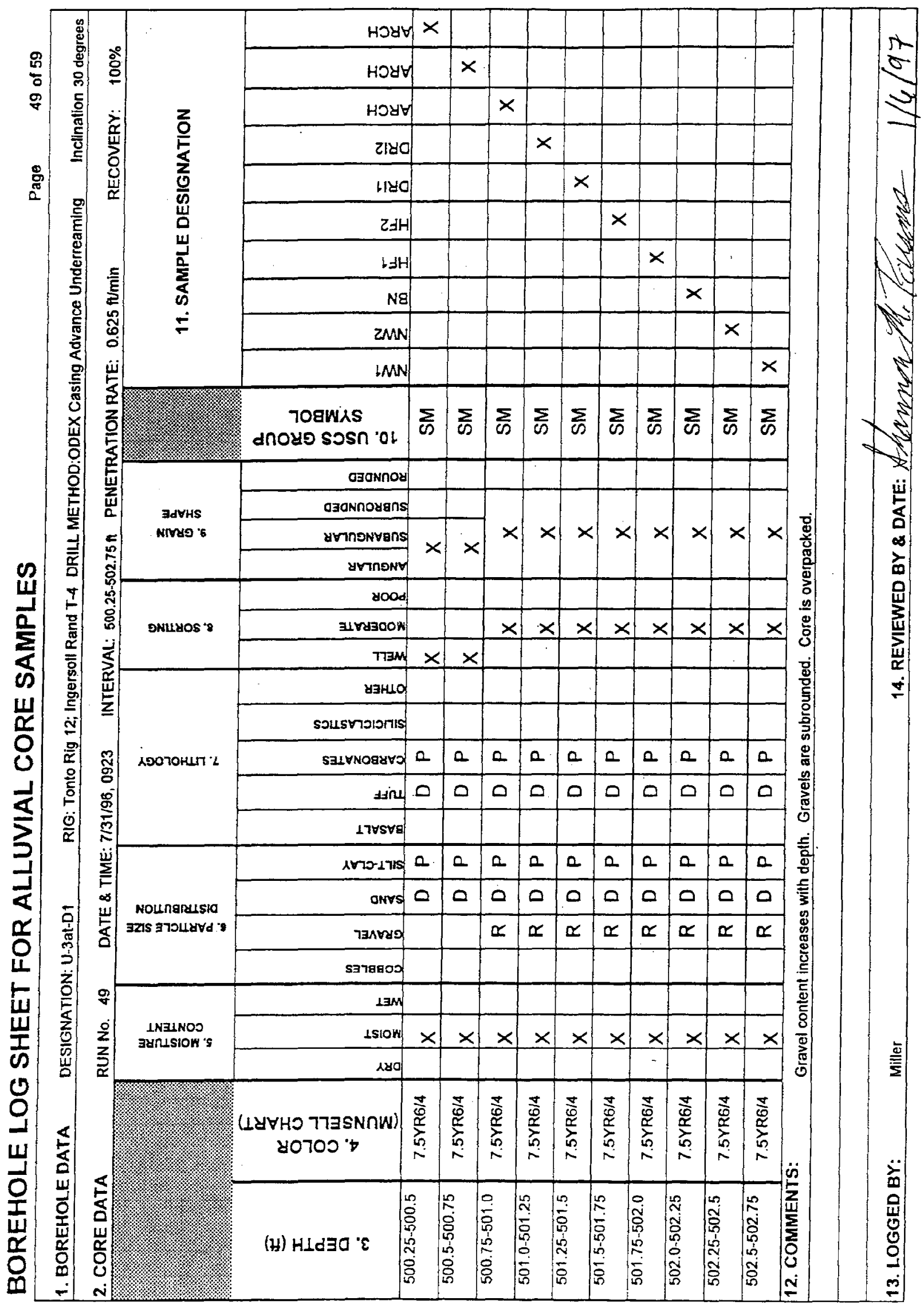




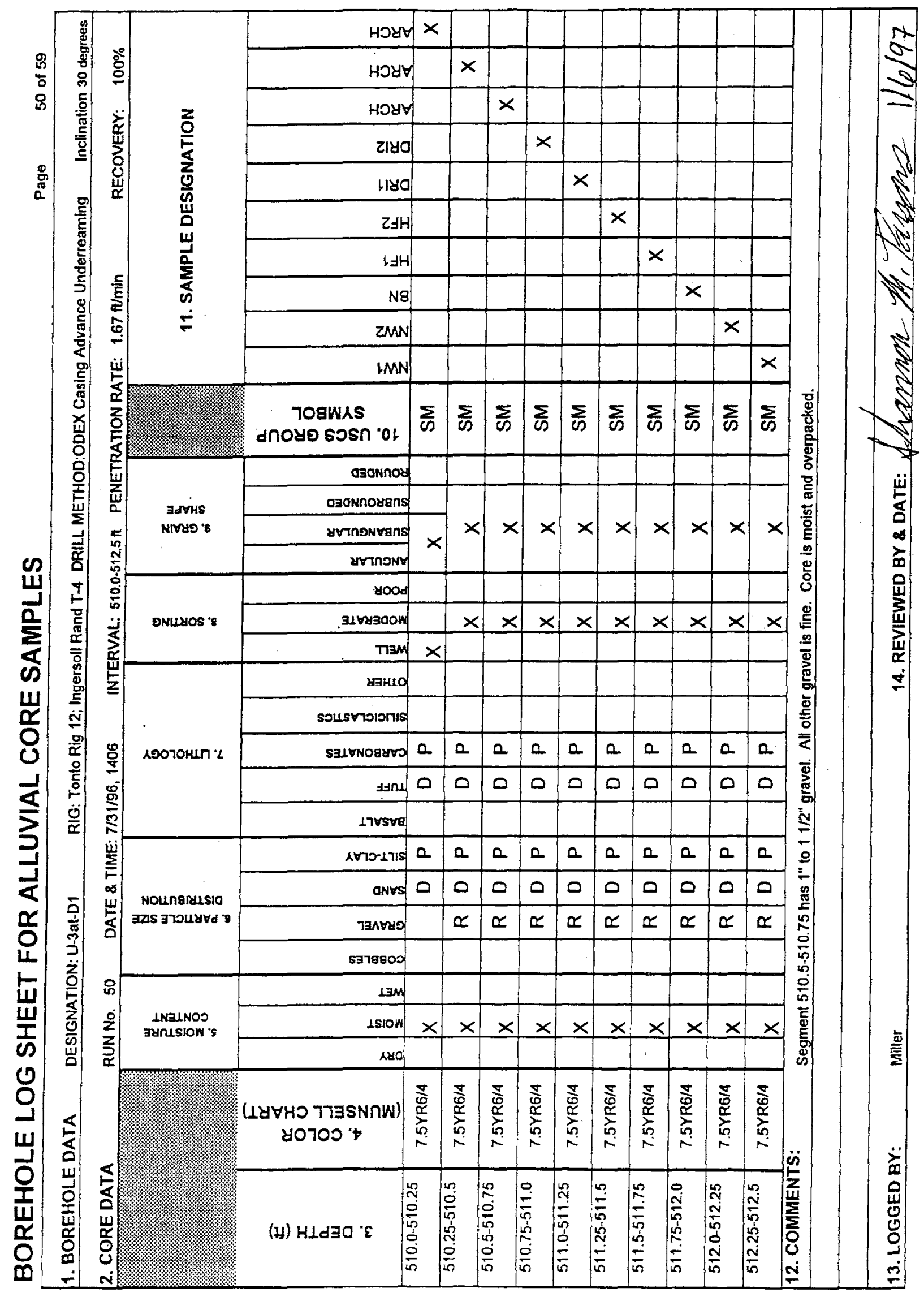

A $\leq n$ 


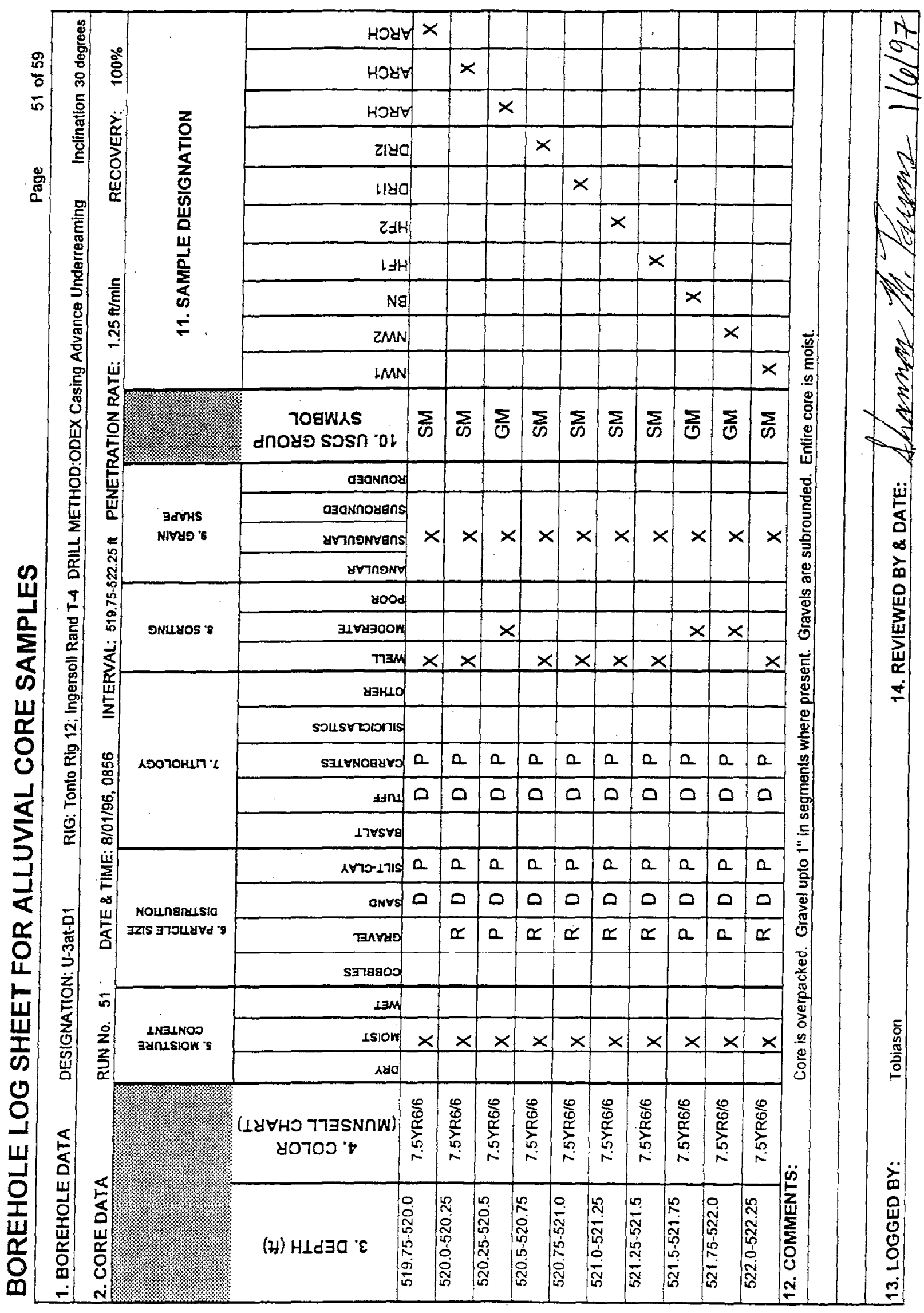




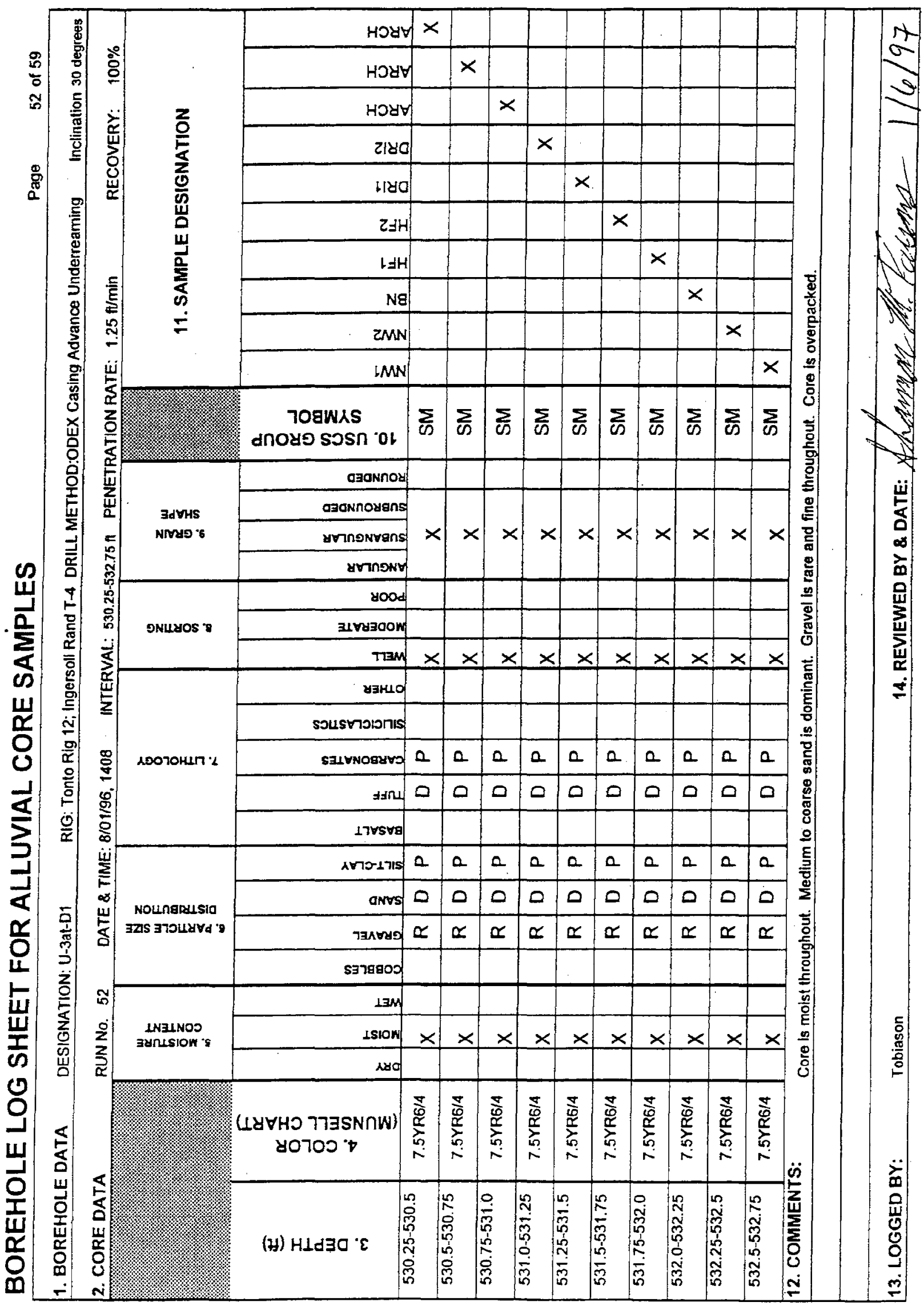




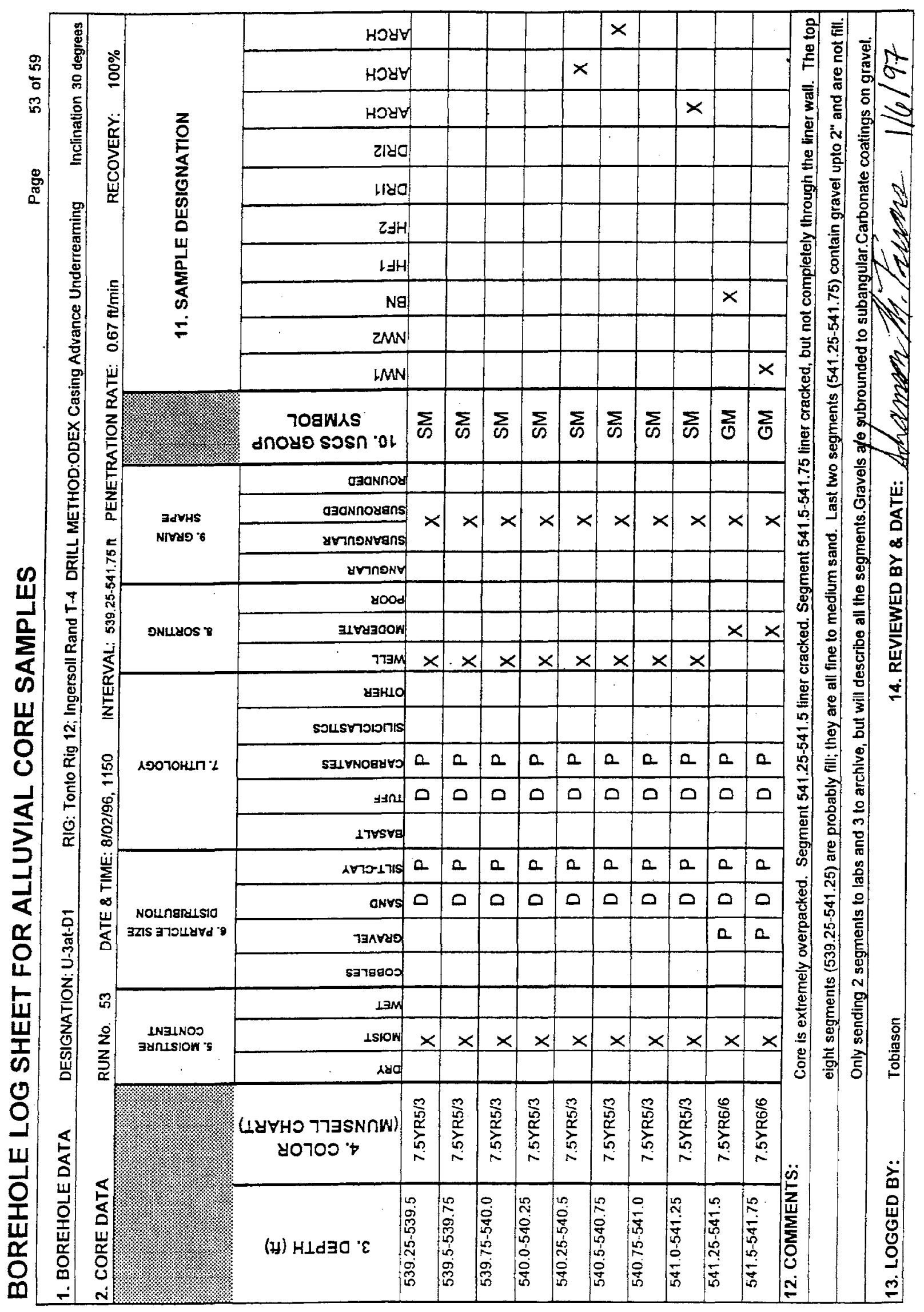




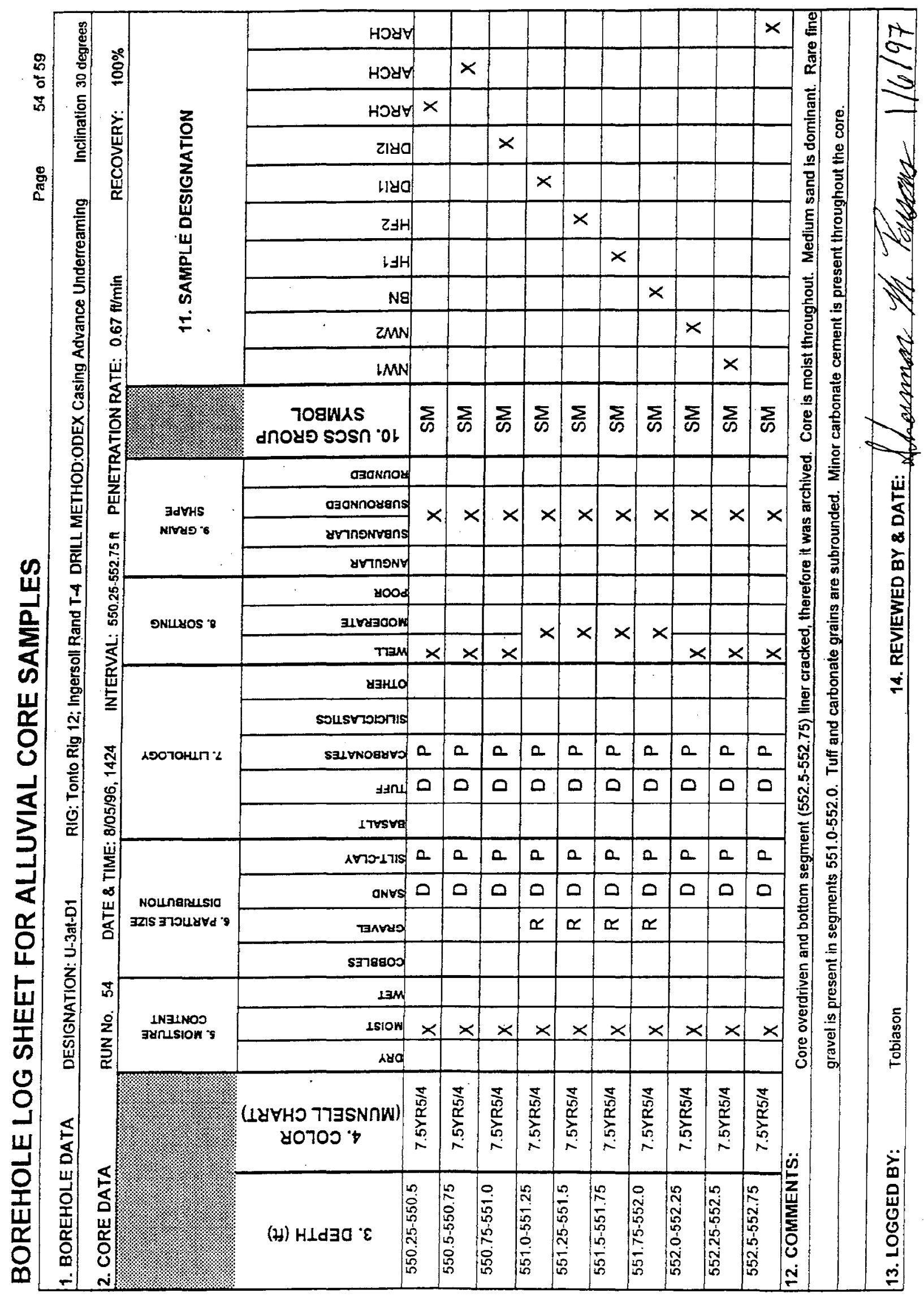




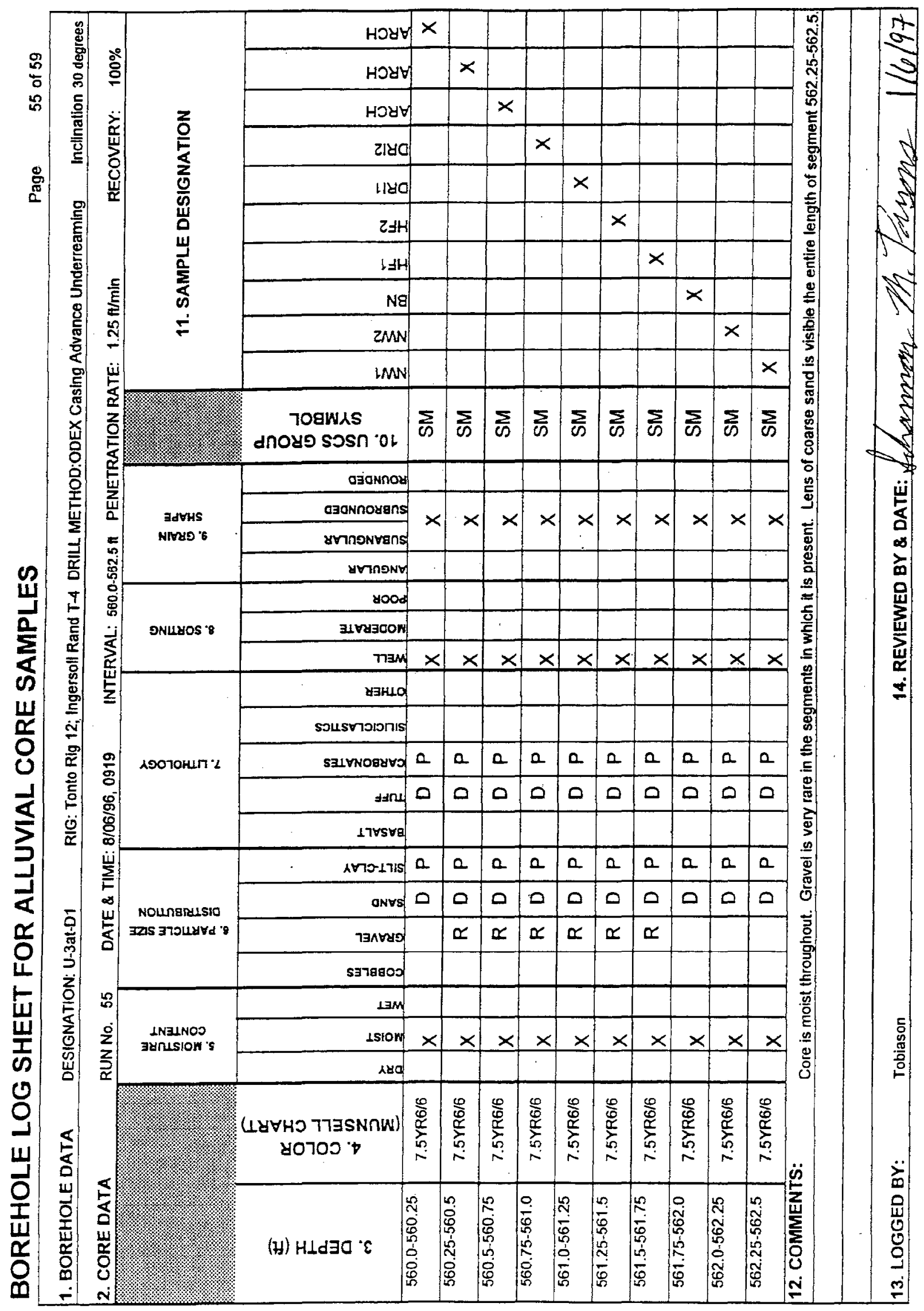




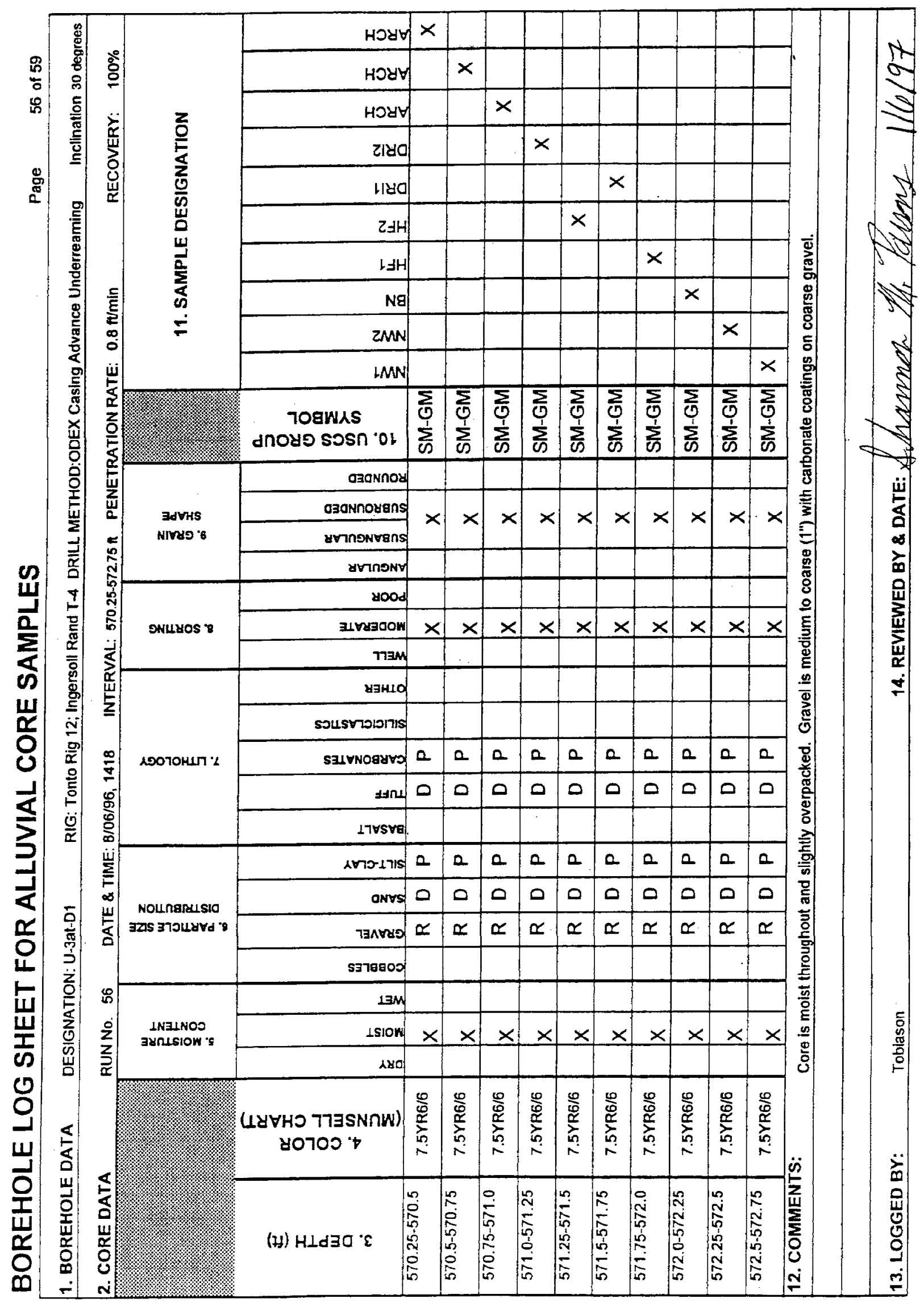

a 2 


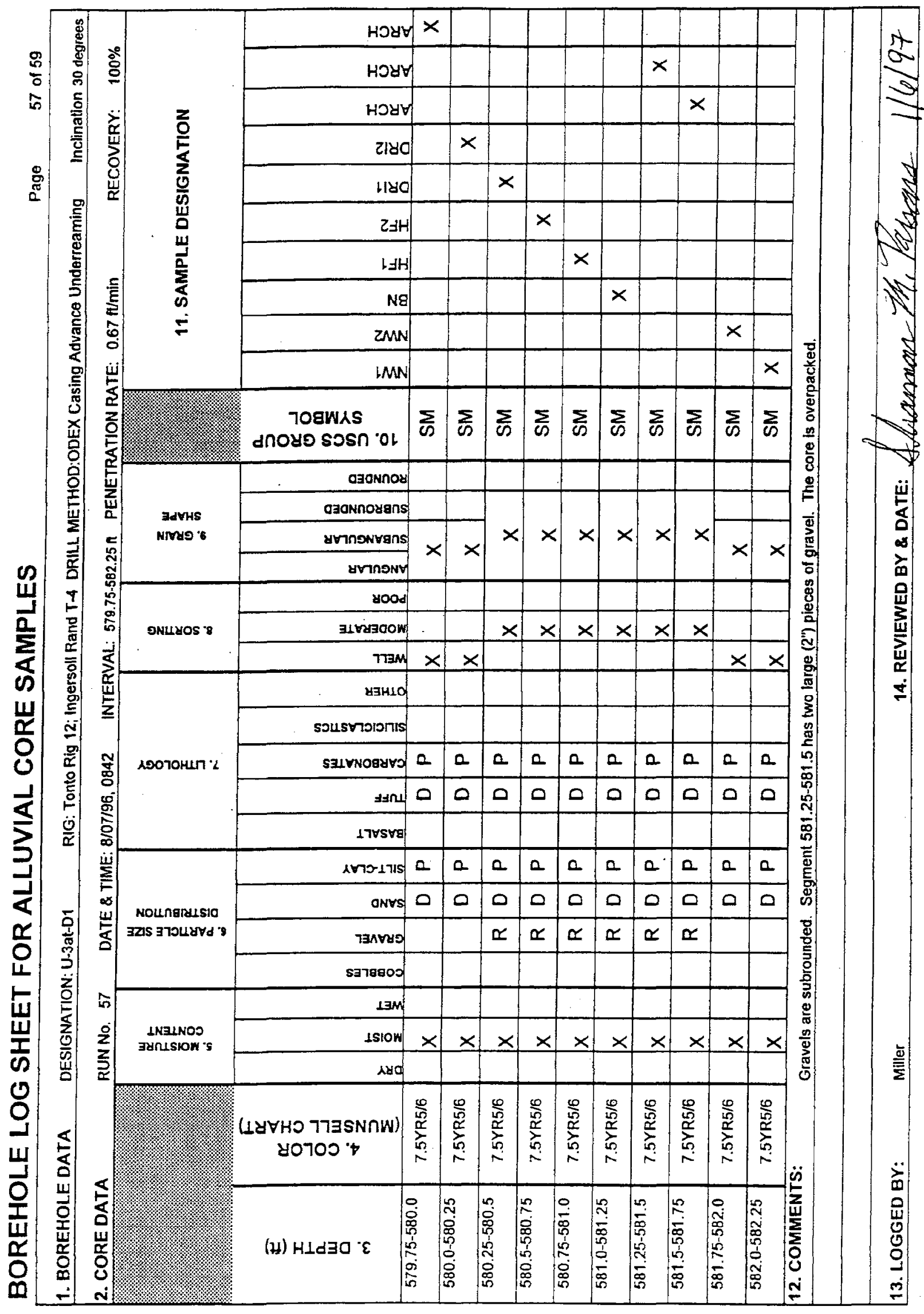




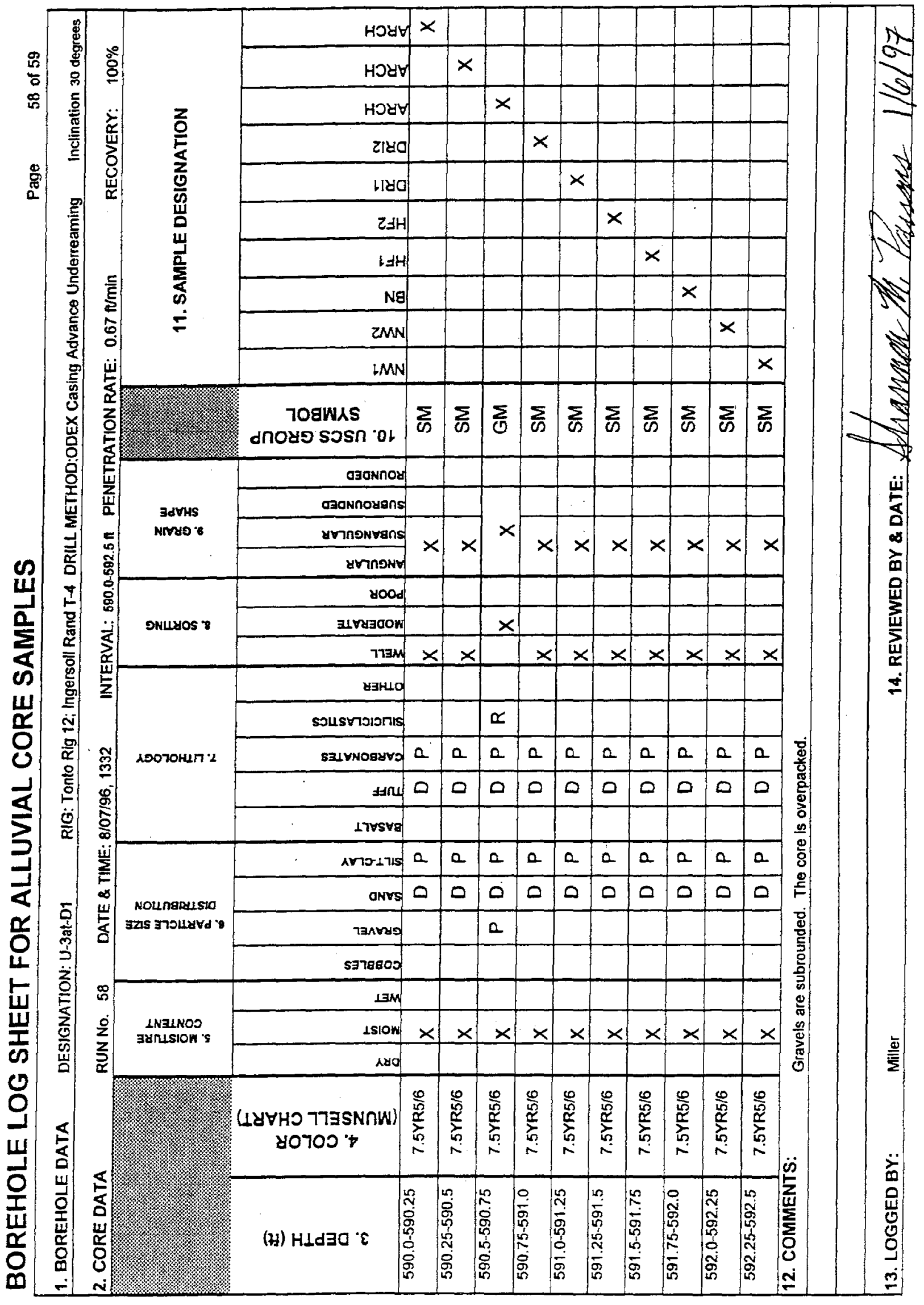




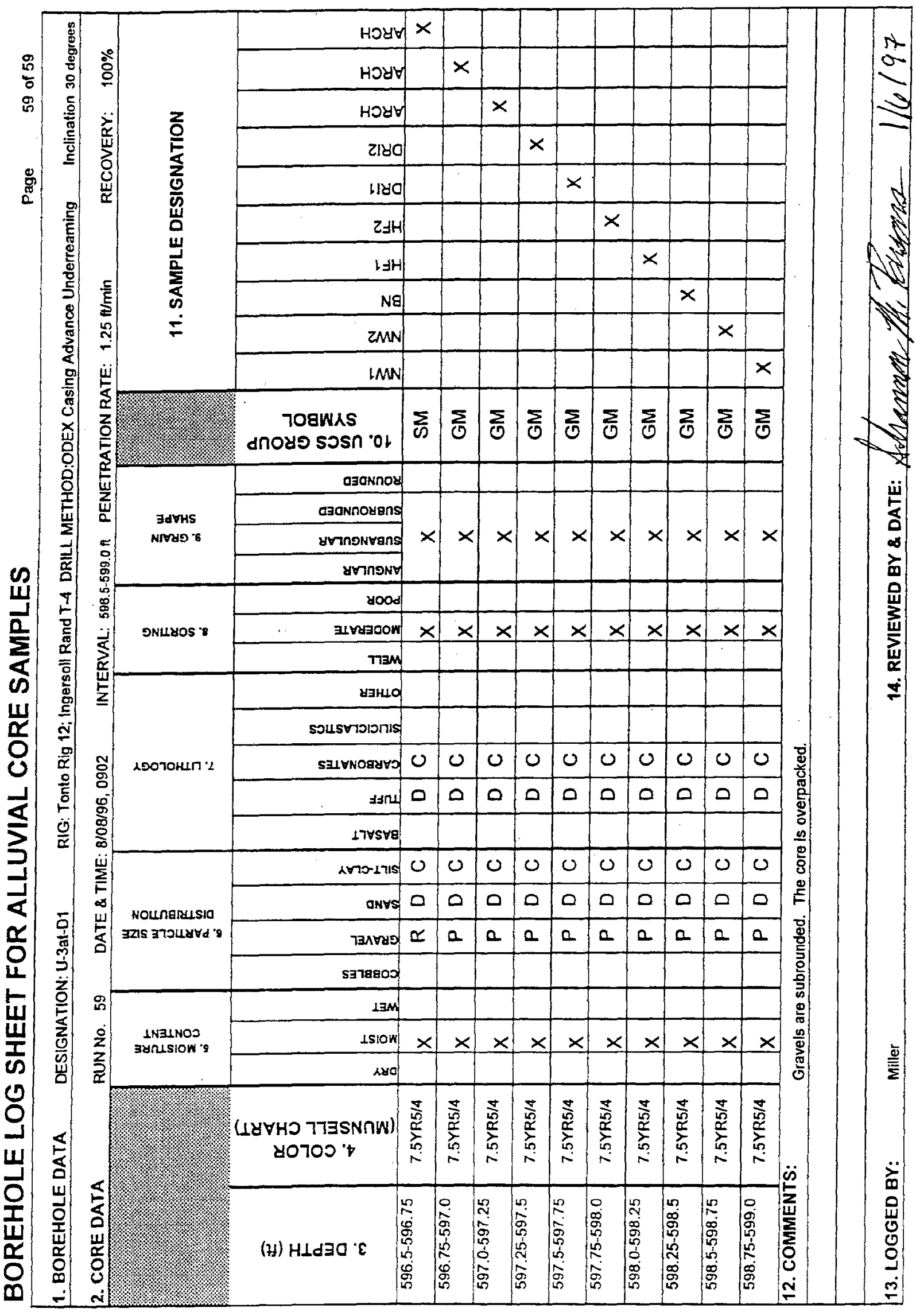




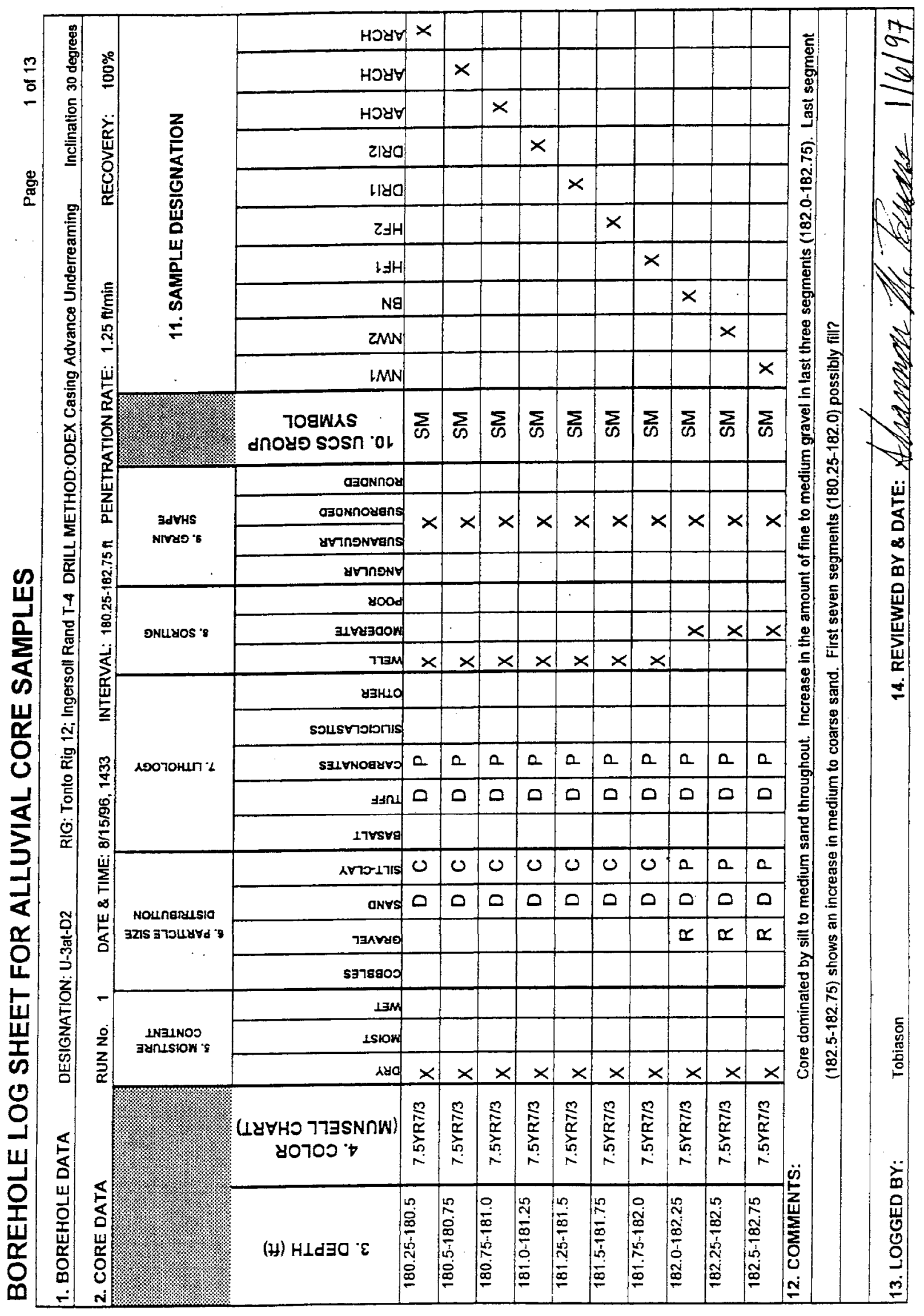




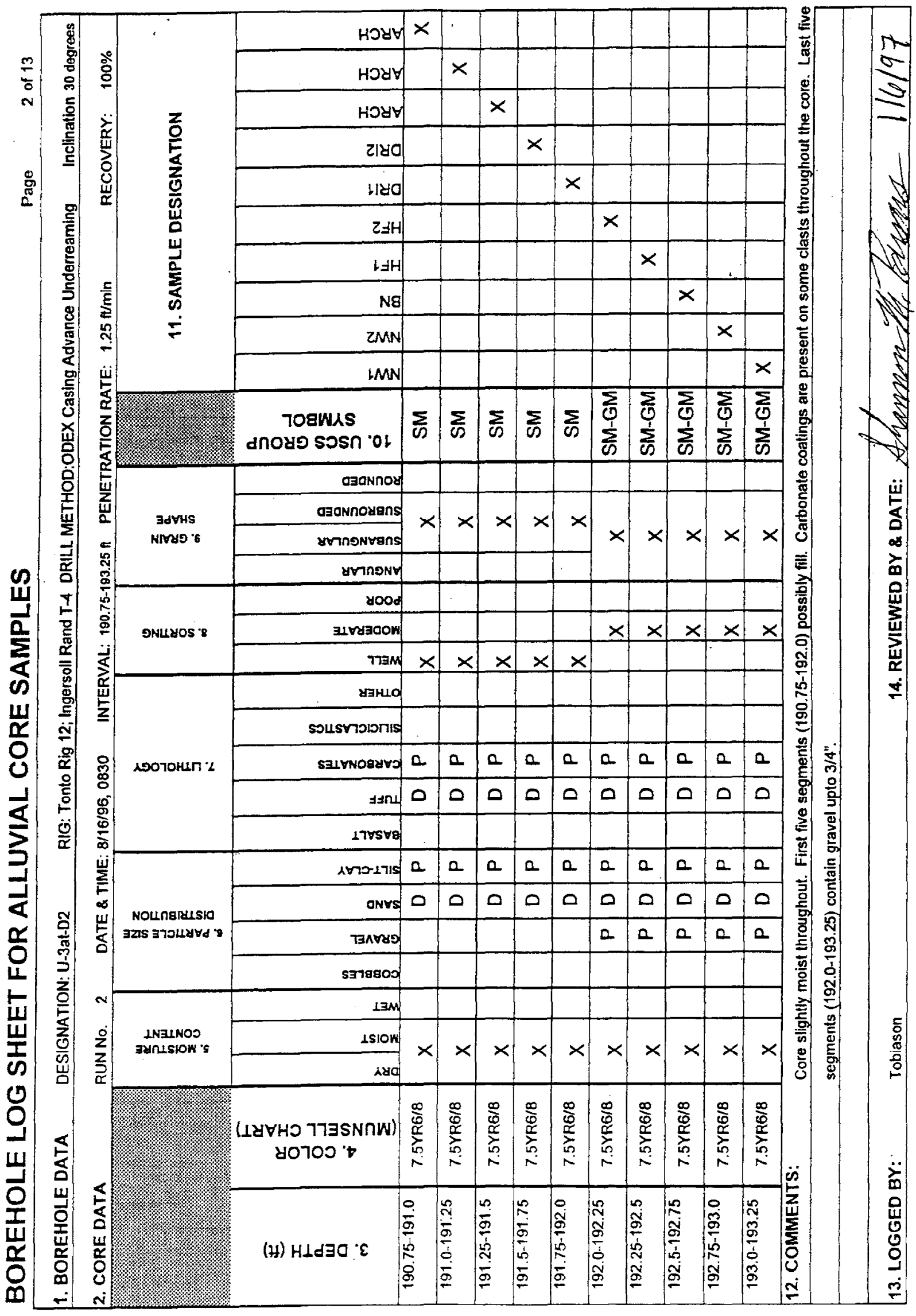




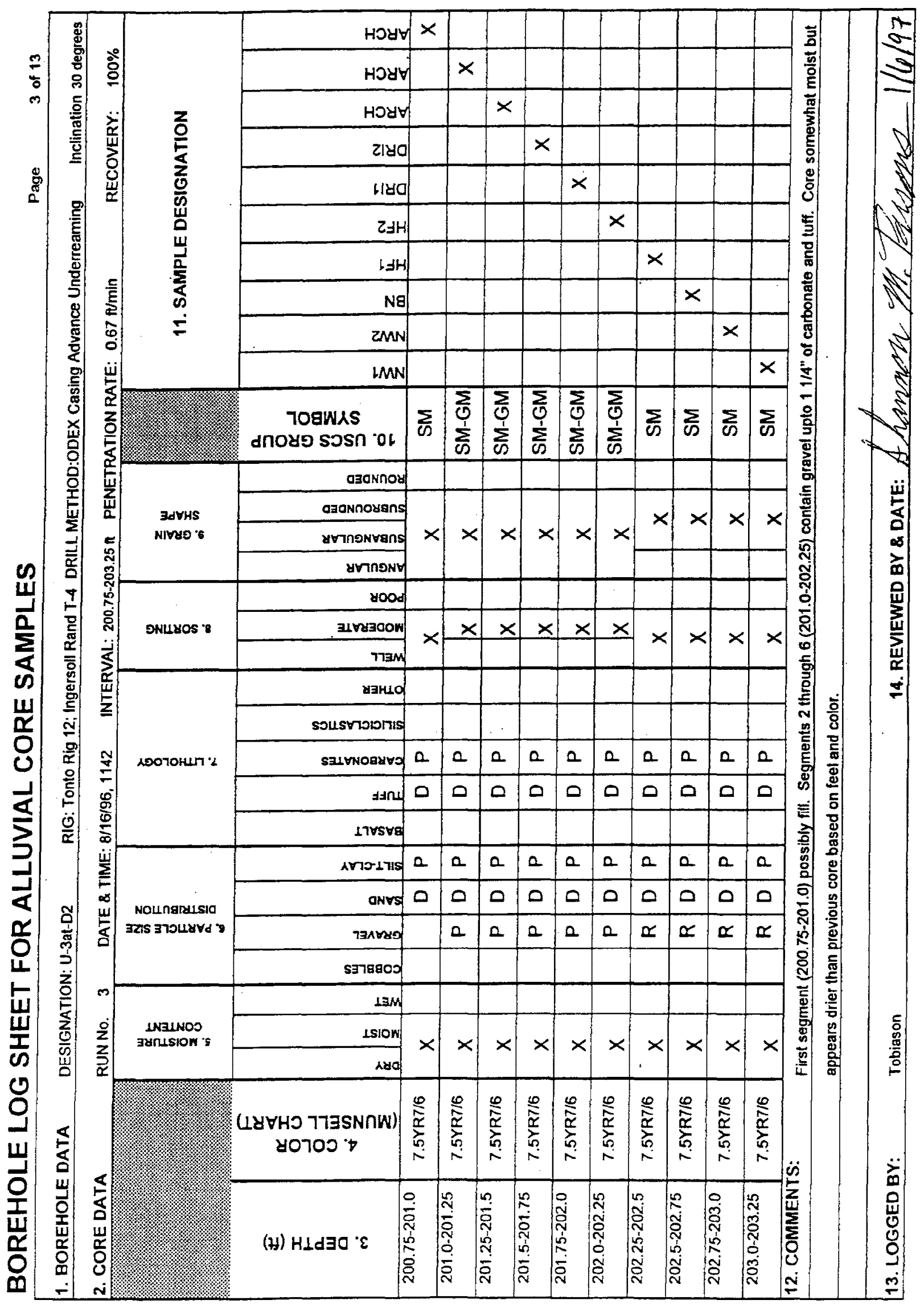




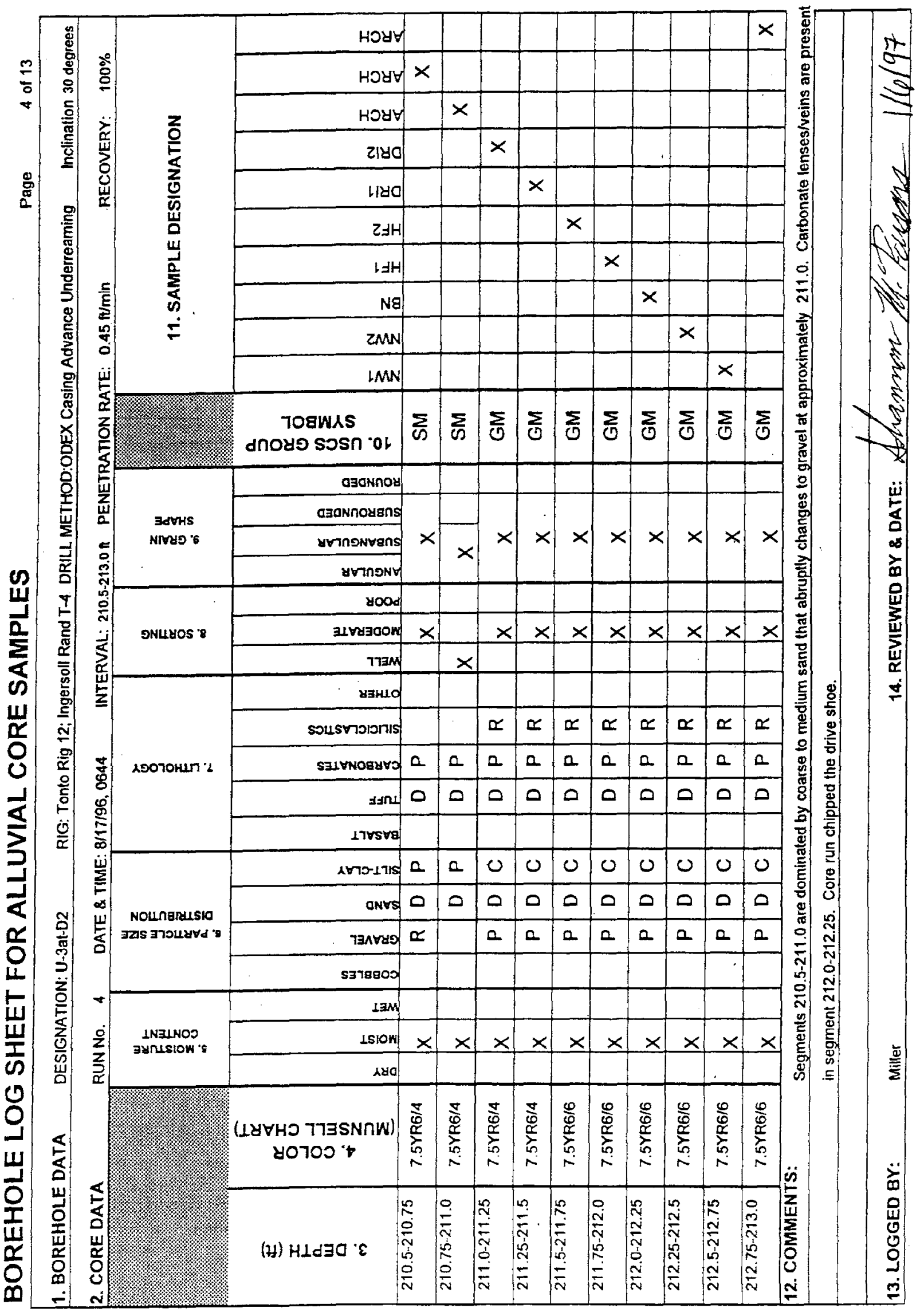




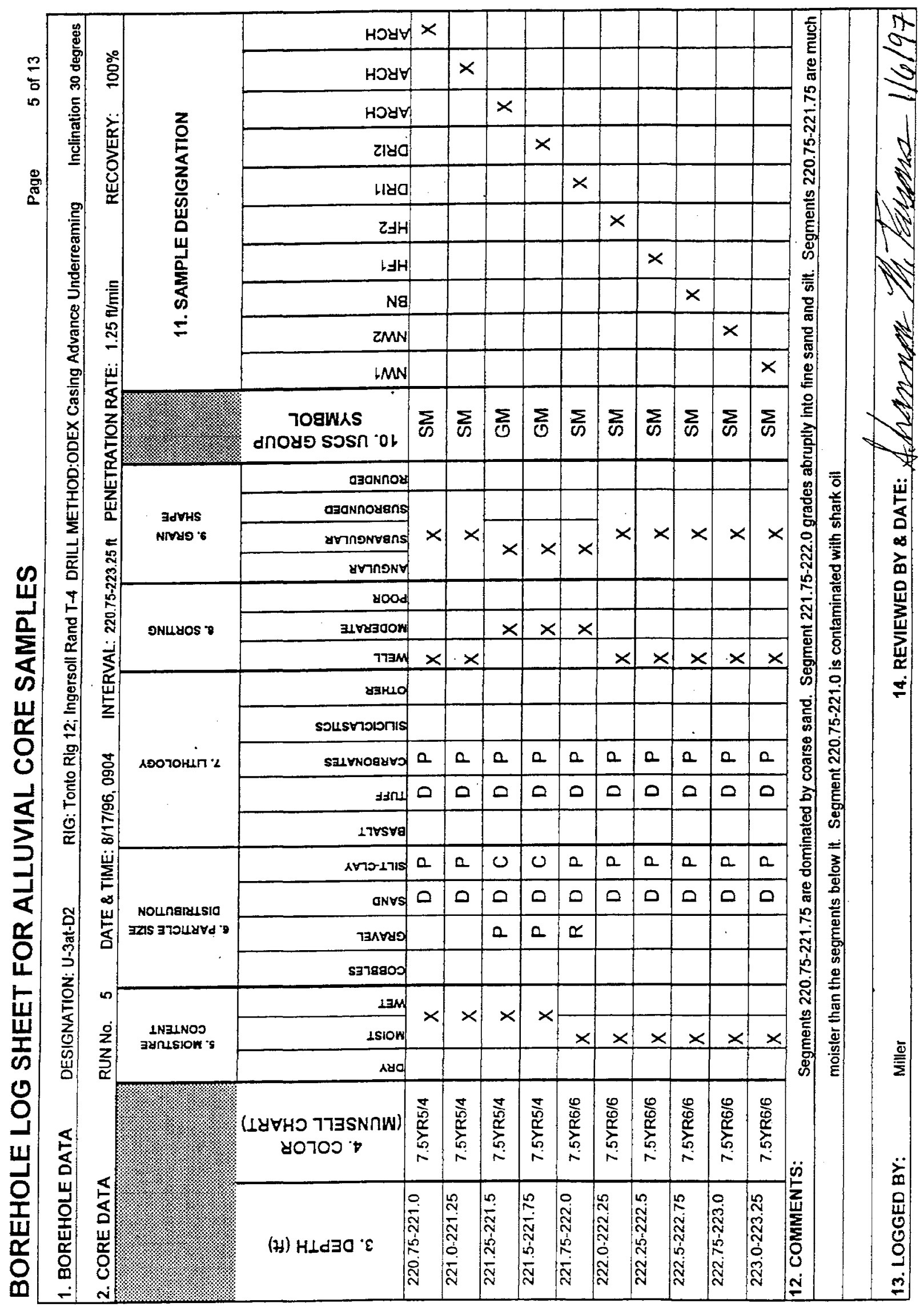




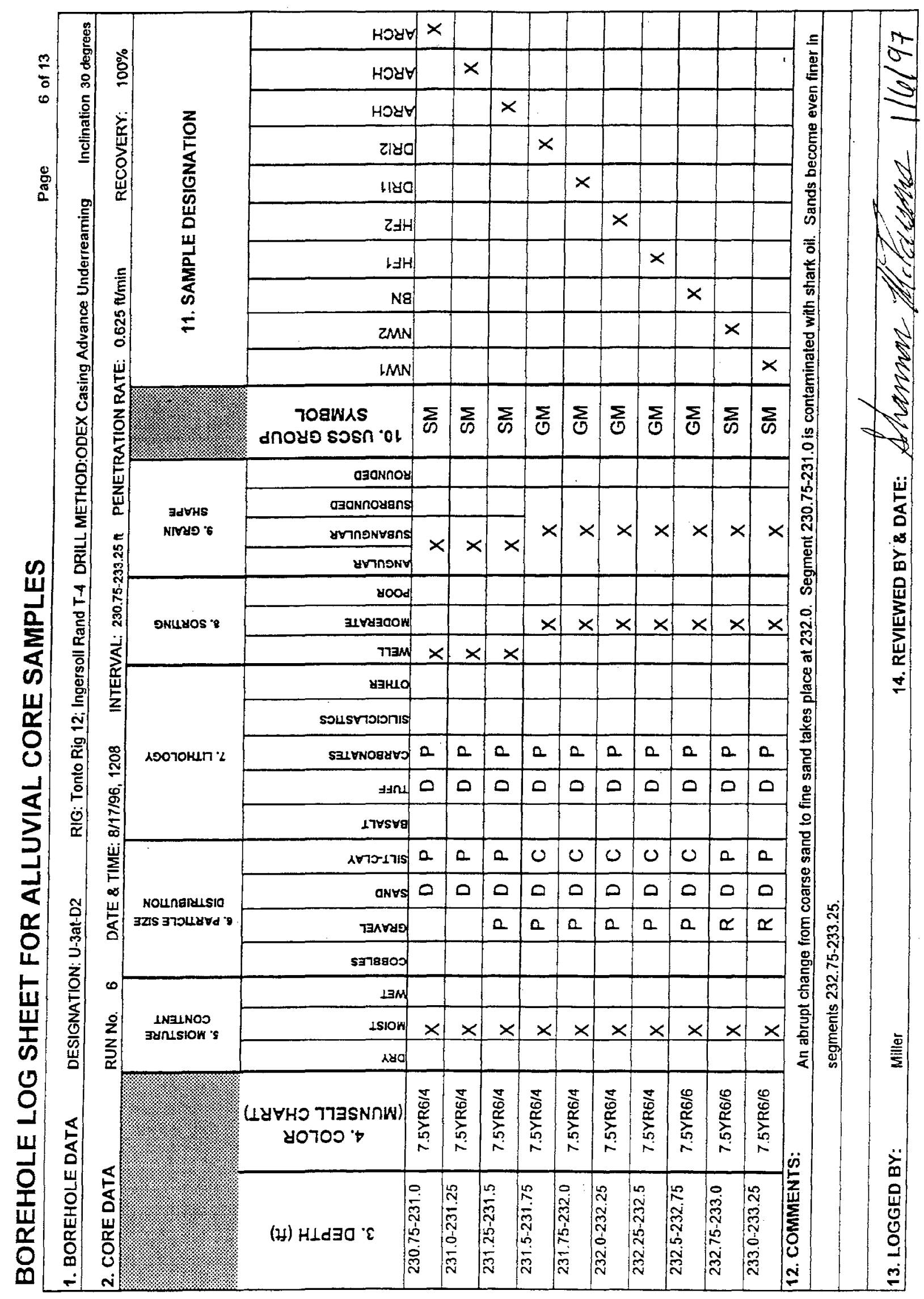




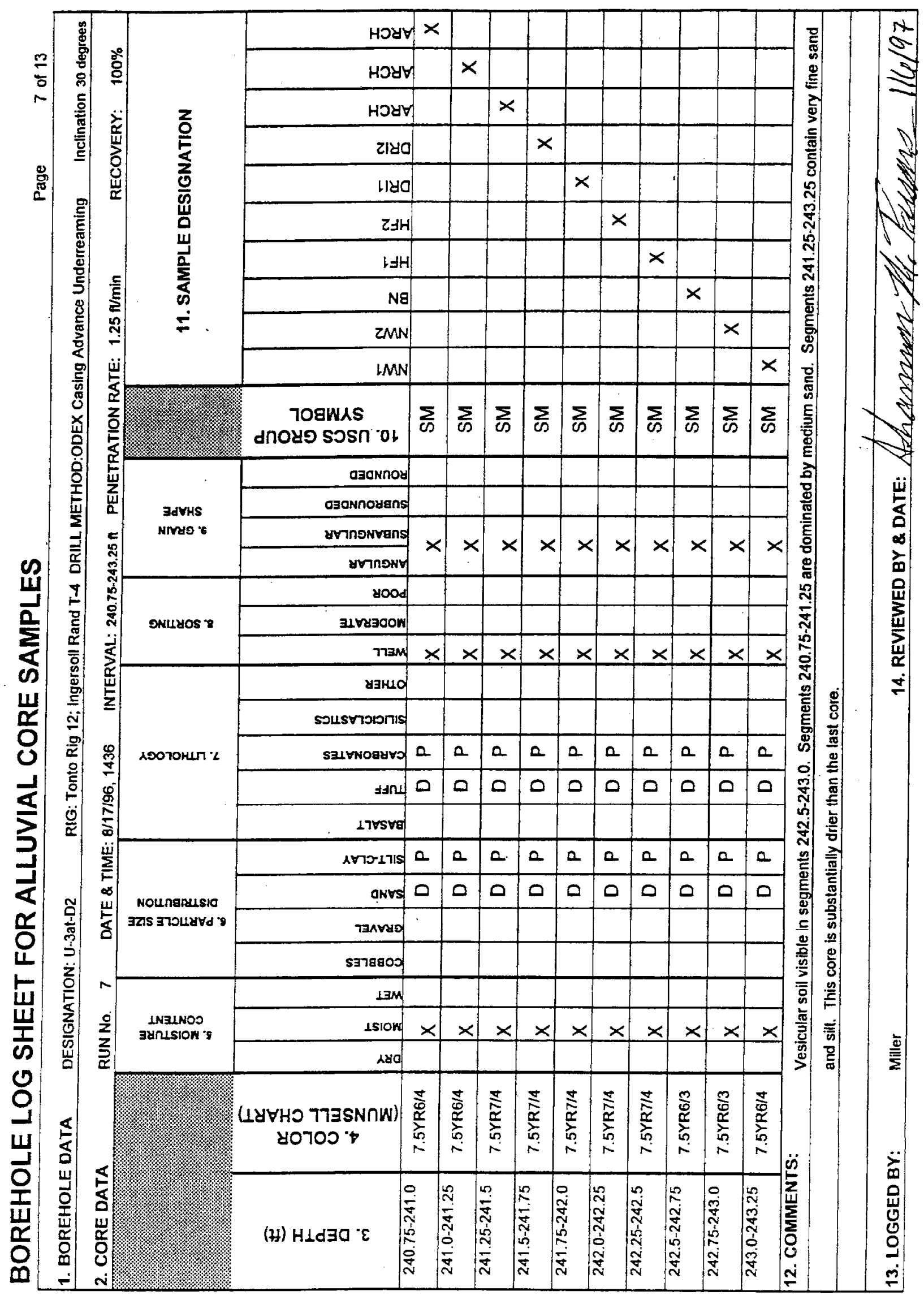




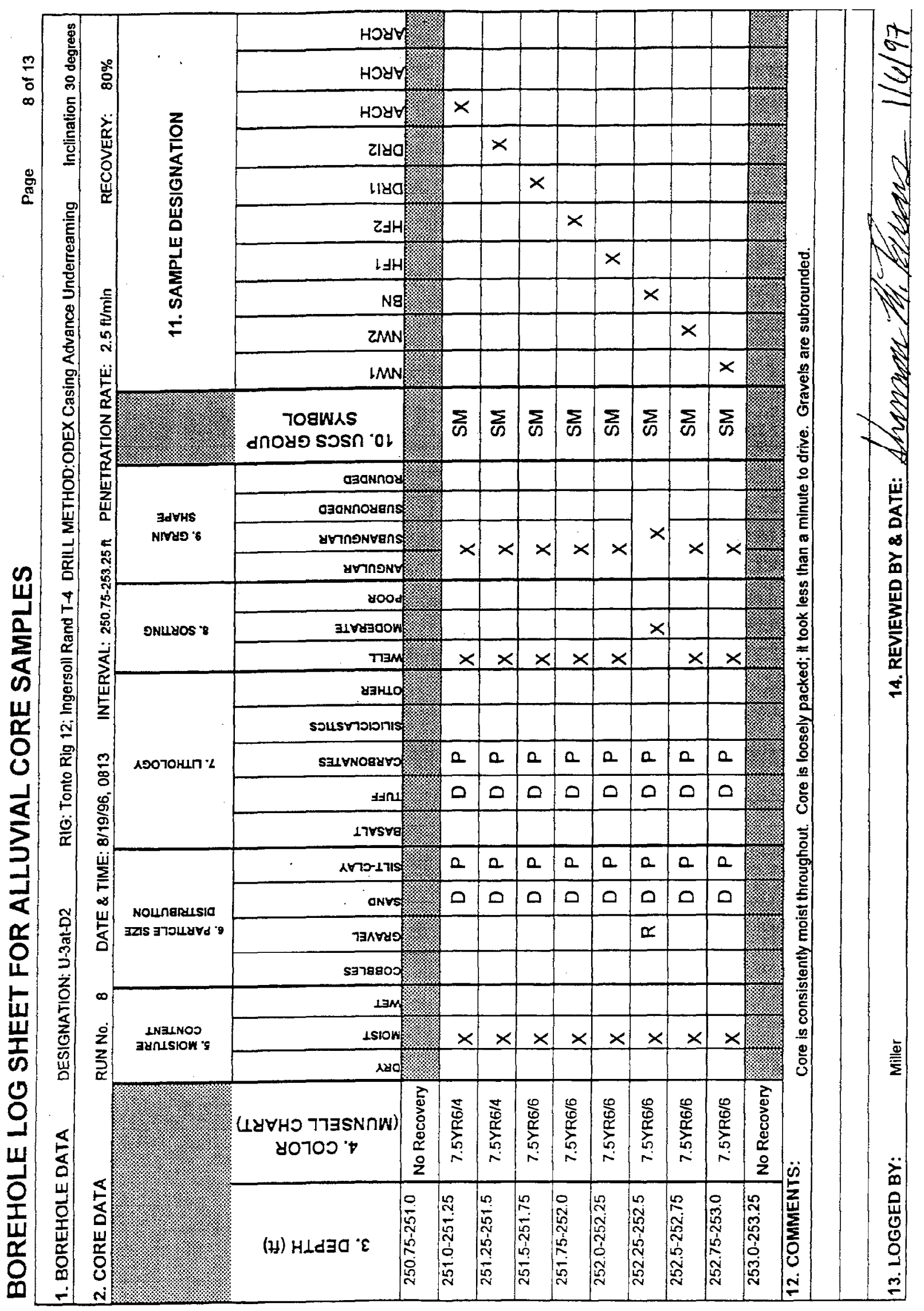




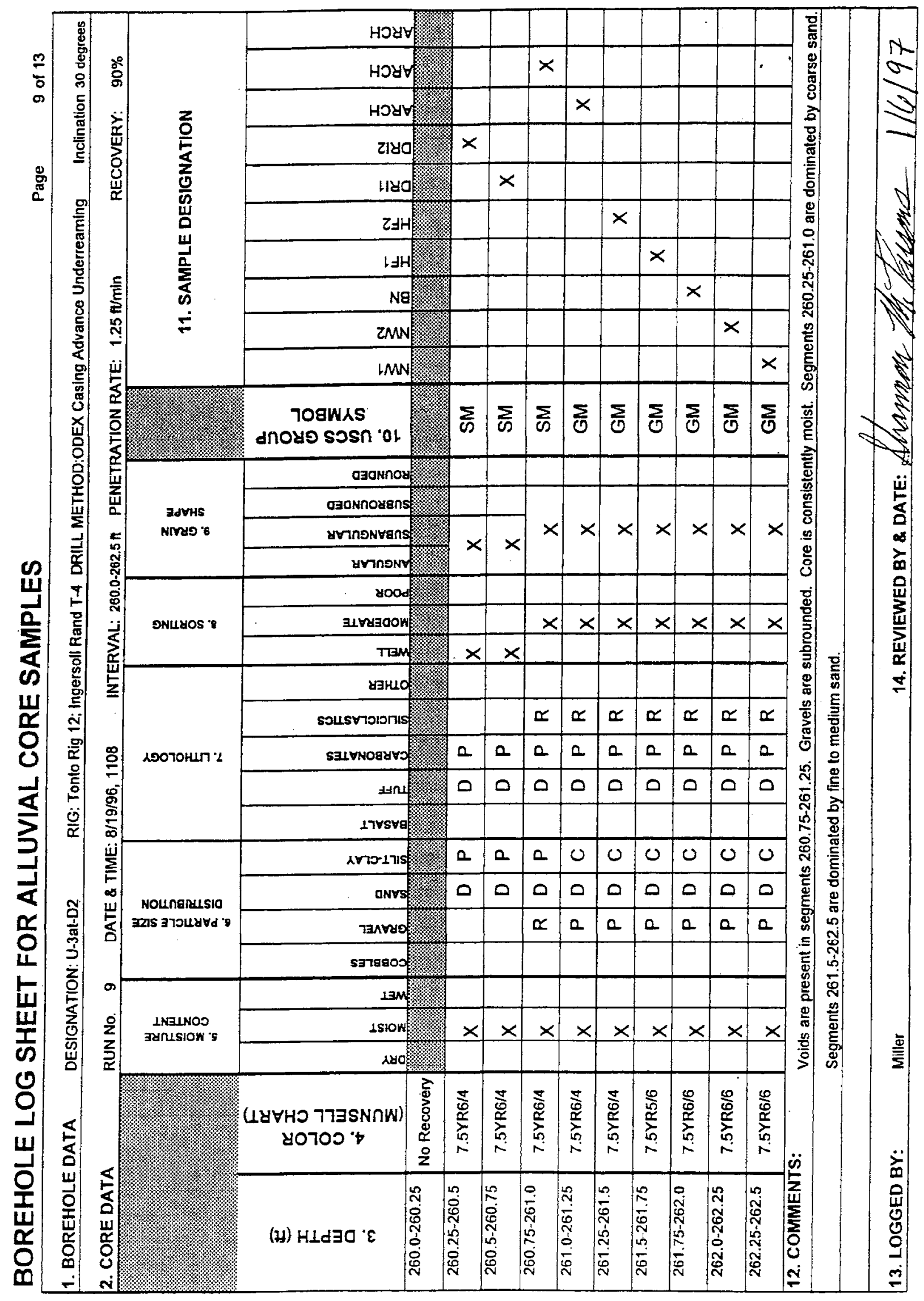

168 


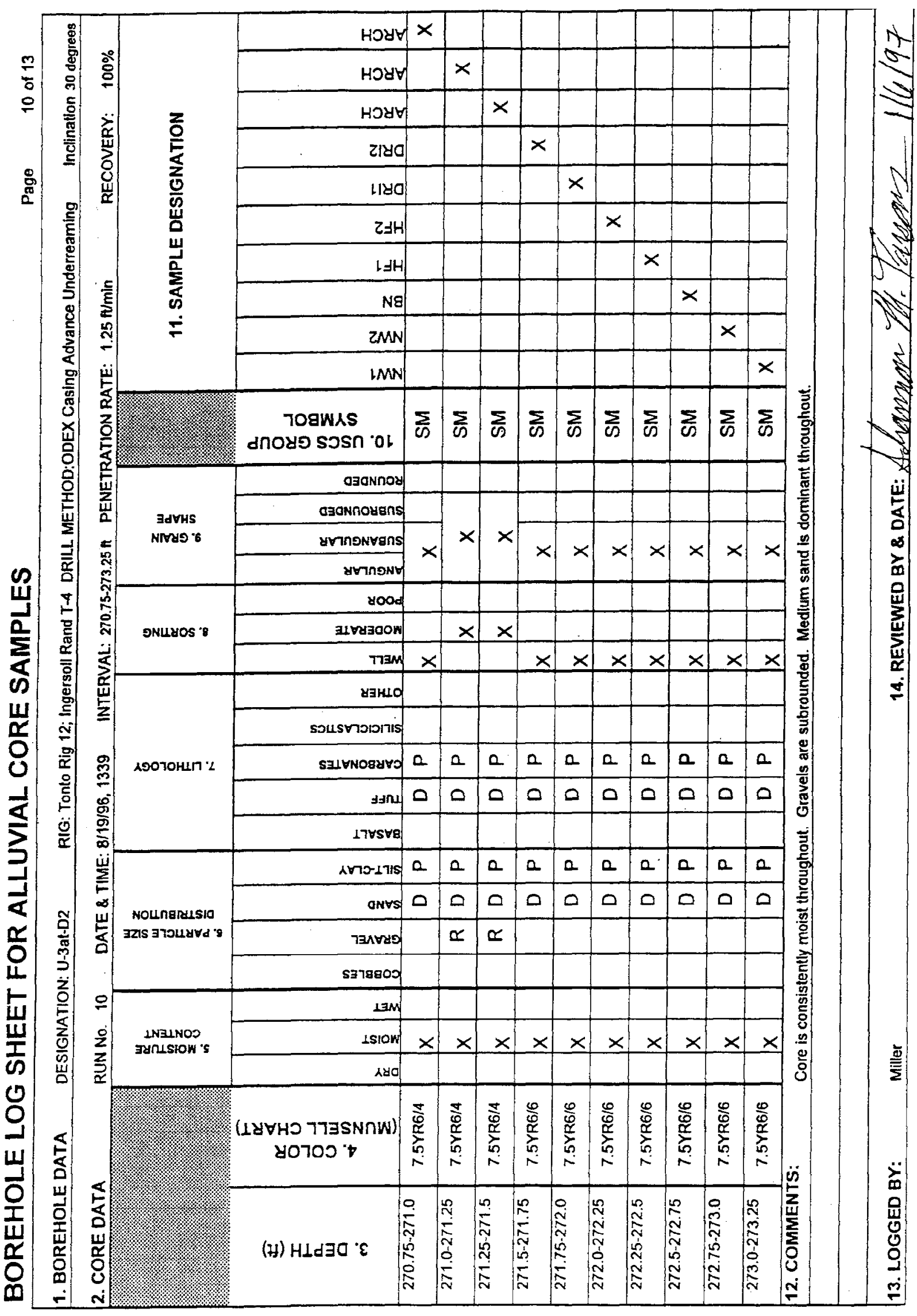




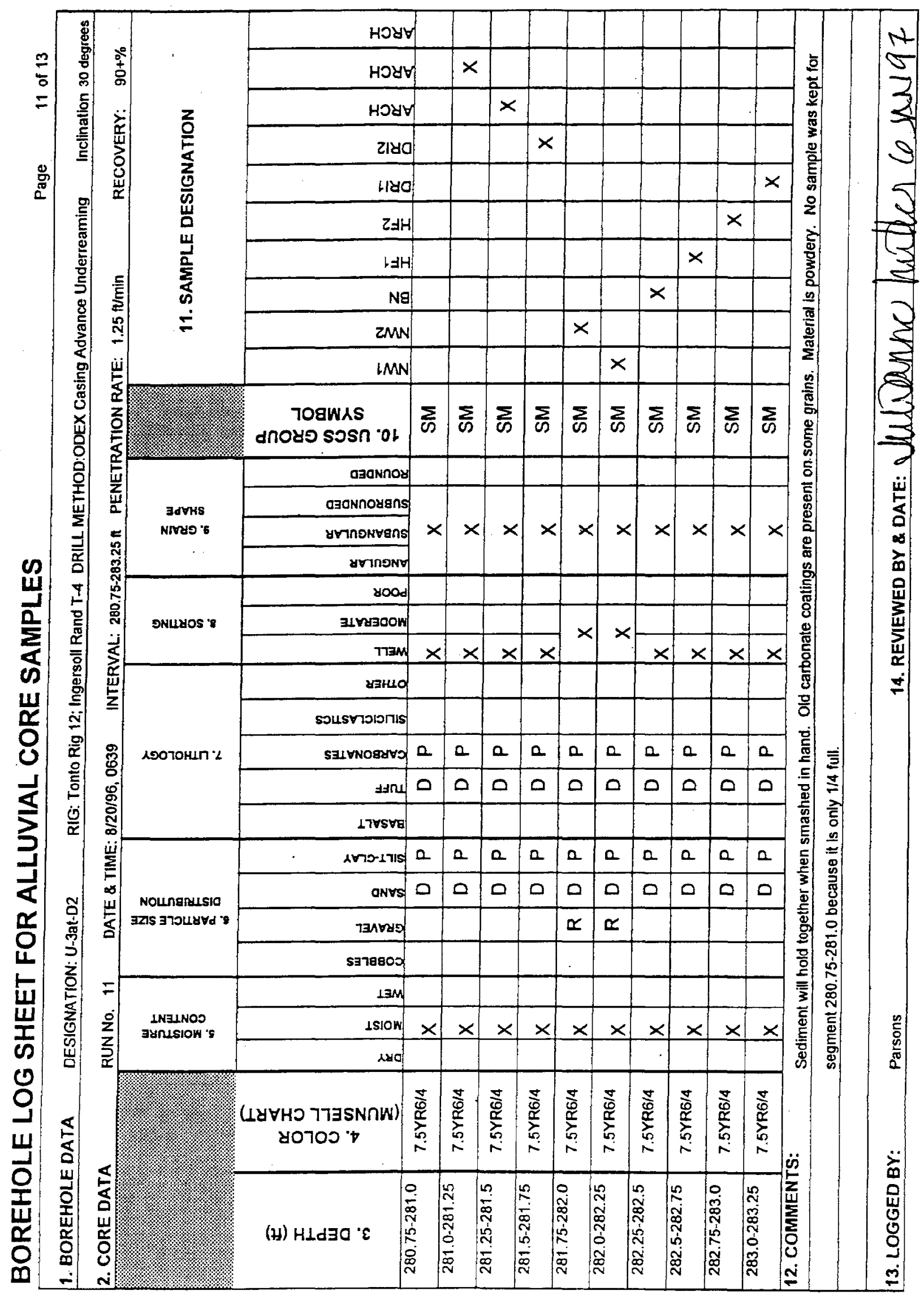




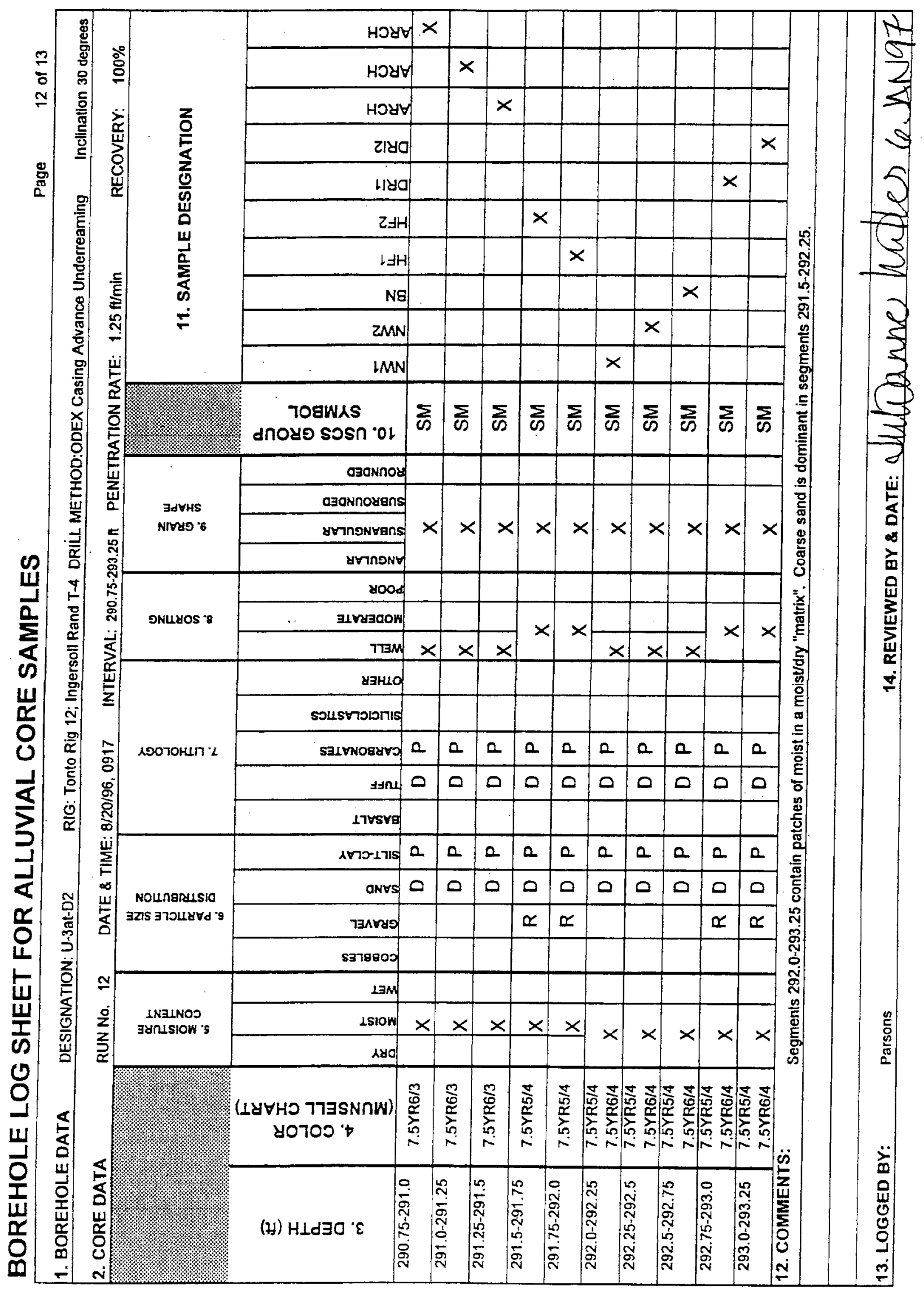




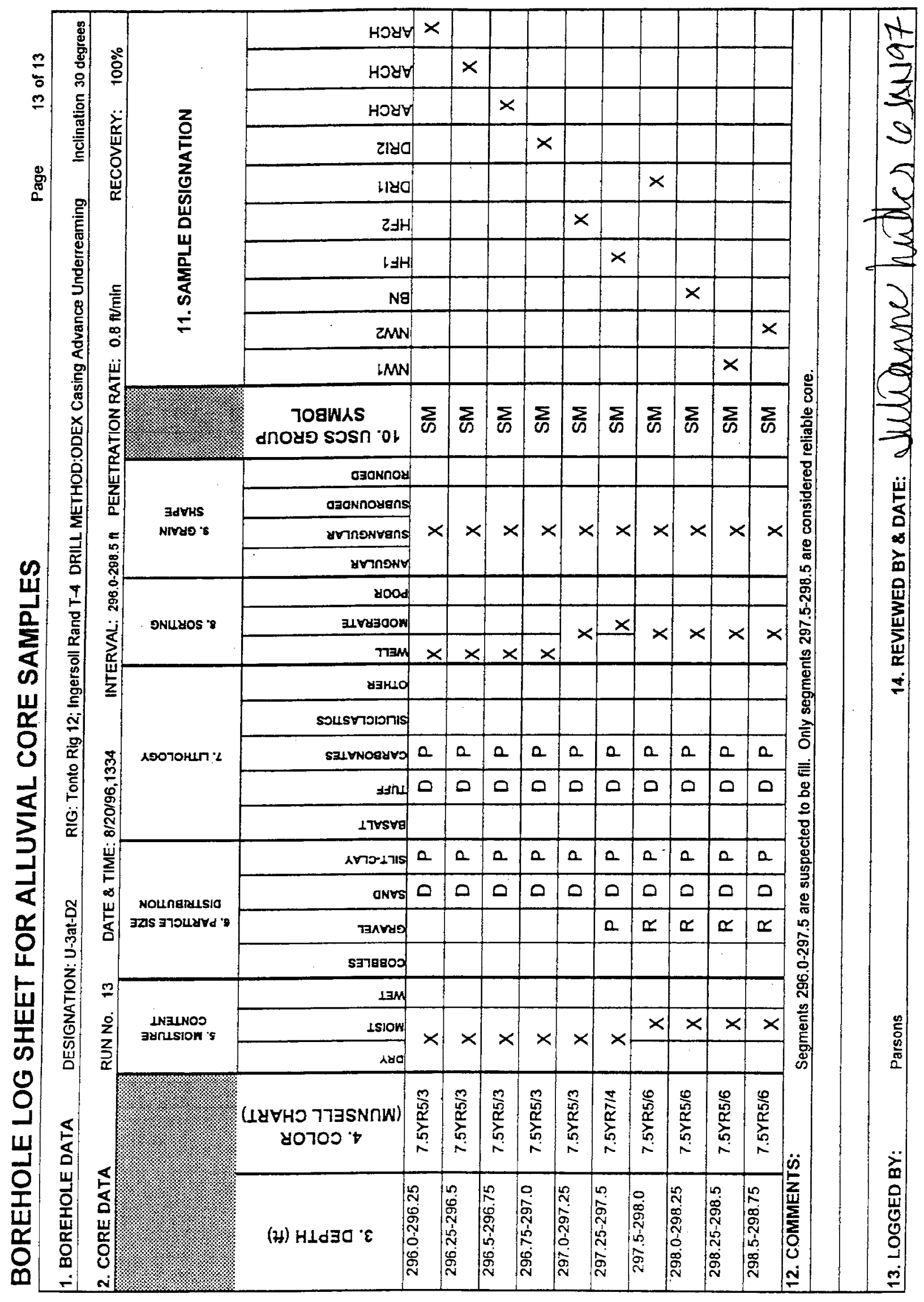




\title{
U3at Collapse Zone
}

\author{
Appendix B
}

\section{Characterization Data Tables}


Table B-1

Particle Density for U-3at-D1 Characterization Samples

(Depth in meters; density in kilograms per cubic meters)

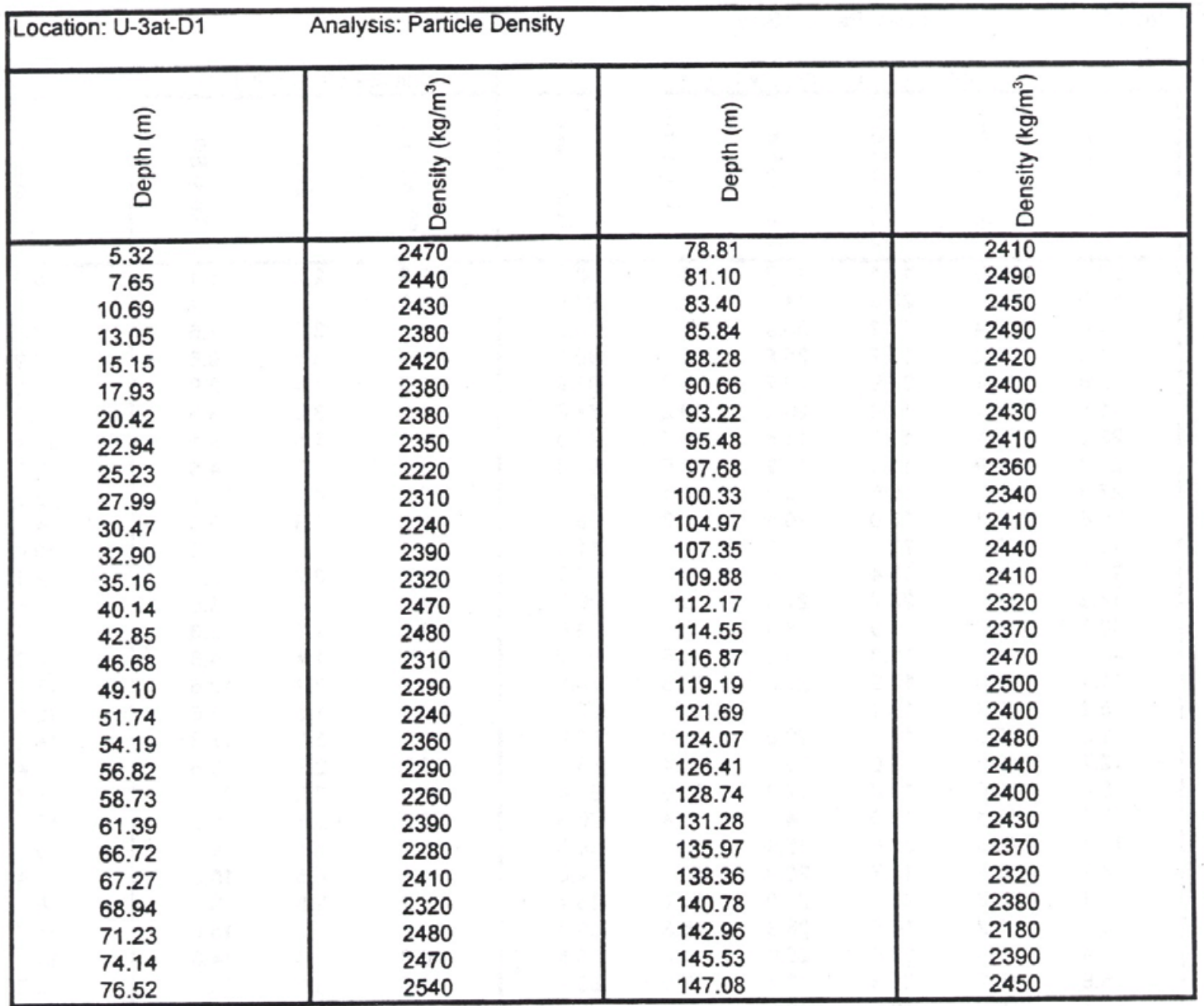


Table B-2

Particle Size Distribution for the Fine Earth ( $<2$ millimeters) Fraction for U-at-D1 Characterization Samples

(Depth in meters; particle sizes [weight percent] in millimeters)

\begin{tabular}{|c|c|c|c|c|c|c|c|c|c|c|}
\hline \multicolumn{7}{|c|}{ Location: U-3at-D1 } & & & & \\
\hline \multirow[b]{2}{*}{$\begin{array}{l}\widehat{\underline{E}} \\
\overline{\overline{\bar{z}}} \\
\text { D̆ }\end{array}$} & \multicolumn{6}{|c|}{ Sand $(0.05-2 \mathrm{~mm})(w t \%)$} & \multicolumn{3}{|c|}{ Silt $(2-50 \mathrm{~mm})(\mathrm{wt} \%)$} & \multirow{2}{*}{$\begin{array}{c}\text { Clay }(<2 \mathrm{~mm})(\mathrm{wt} \%) \\
\frac{\mathrm{d}}{0} \\
\frac{\overline{\mathrm{w}}}{\circ}\end{array}$} \\
\hline & $\begin{array}{l}\text { E } \\
\text { E } \\
\stackrel{-}{-}\end{array}$ & $\frac{E}{E}$ & 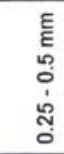 & 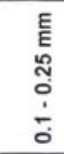 & $\begin{array}{l}E \\
E \\
0 \\
\vdots \\
\vdots \\
0\end{array}$ & 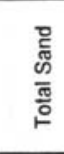 & $\begin{array}{l}E \\
\text { E } \\
\text { ㅇ } \\
\text { 유 }\end{array}$ & $\begin{array}{l}E \\
E \\
\stackrel{N}{ } \\
\dot{\sim}\end{array}$ & $\frac{\text { ज }}{\frac{5}{0}}$ & \\
\hline 5.32 & 30.3 & 25.2 & $\overline{17.1}$ & 11.2 & 5.1 & 88.9 & 2.9 & 2.2 & 5.1 & 6.0 \\
\hline 7.65 & 18.0 & 30.7 & 28.6 & 14.1 & 2.5 & 93.9 & 1.3 & 1.1 & 2.4 & 3.7 \\
\hline 10.69 & 4.6 & 7.4 & 17.2 & 35.9 & 19.4 & 84.5 & 4.4 & 3.2 & 7.6 & 7.9 \\
\hline 13.05 & 11.3 & 13.2 & 17.7 & 25.5 & 12.7 & 80.5 & 6.1 & 3.5 & 9.6 & 9.9 \\
\hline 15.15 & 12.8 & 18.1 & 29.9 & 26.2 & 6.0 & 92.9 & 1.5 & 1.4 & 2.9 & 4.2 \\
\hline 17.93 & 11.5 & 14.1 & 17.4 & 20.8 & 10.2 & 74.0 & 9.9 & 3.6 & 13.5 & 12.5 \\
\hline 20.42 & 23.2 & 19.1 & 15.7 & 11.8 & 5.7 & 75.5 & 6.6 & 1.5 & 8.1 & 16.4 \\
\hline 22.94 & 25.8 & 24.9 & 19.6 & 11.9 & 3.6 & 85.8 & 3.2 & 1.3 & 4.5 & 9.7 \\
\hline 25.23 & 27.6 & 17.6 & 10.6 & 9.2 & 7.1 & 72.0 & 10.6 & 4.1 & 14.7 & 13.3 \\
\hline 27.99 & 25.6 & 20.8 & 22.0 & 16.4 & 5.3 & 90.1 & 3.2 & 1.8 & 5.0 & 4.9 \\
\hline 30.47 & 11.9 & 20.0 & 23.4 & 11.0 & 4.7 & 71.0 & 7.7 & 1.3 & 9.0 & 20.0 \\
\hline 32.90 & 27.5 & 31.1 & 15.4 & 8.0 & 3.1 & 85.2 & 2.0 & 0.7 & 2.7 & 12.1 \\
\hline 35.16 & 14.3 & 19.6 & 25.7 & 21.5 & 5.6 & 86.8 & 4.0 & 1.6 & 5.6 & 7.6 \\
\hline 40.14 & 40.3 & 32.3 & 9.9 & 8.0 & 3.1 & 93.6 & 1.2 & 1.1 & 2.3 & 4.1 \\
\hline 42.85 & 48.2 & 24.4 & 11.3 & 5.3 & 1.9 & 91.2 & 3.2 & 1.4 & 4.6 & 4.2 \\
\hline 46.68 & 11.1 & 12.0 & 17.9 & 22.2 & 10.6 & 73.8 & 10.2 & 2.4 & 12.6 & 13.6 \\
\hline 49.10 & 5.2 & 7.2 & 19.1 & 36.5 & 14.8 & 82.9 & 5.1 & 1.5 & 6.6 & 10.5 \\
\hline 51.74 & 2.3 & 5.0 & 13.4 & 29.0 & 18.3 & 67.9 & 12.3 & 5.0 & 17.3 & 14.8 \\
\hline 54.19 & 12.7 & 13.8 & 23.0 & 25.1 & 8.4 & 83.0 & 6.7 & 2.9 & 9.6 & 7.4 \\
\hline 56.82 & 8.6 & 10.0 & 12.0 & 17.0 & 15.9 & 63.4 & 15.0 & 7.2 & 22.2 & 14.4 \\
\hline 58.73 & 22.9 & 17.4 & 16.0 & 14.8 & 5.4 & 76.5 & 7.3 & 2.3 & 9.6 & 13.9 \\
\hline 61.39 & 17.1 & 22.3 & 30.4 & 15.9 & 3.8 & 89.5 & 2.7 & 1.4 & 4.1 & 6.4 \\
\hline 66.72 & 4.7 & 6.4 & 13.7 & 28.9 & 20.3 & 74.0 & 11.1 & 4.5 & 15.6 & 10.4 \\
\hline 67.27 & 8.1 & 13.3 & 25.2 & 29.0 & 10.1 & 85.7 & 5.2 & 2.8 & 8.0 & 6.3 \\
\hline 68.94 & 3.7 & 6.2 & 14.9 & 28.3 & 16.3 & 69.3 & 10.8 & 4.2 & 15.0 & 15.7 \\
\hline 71.23 & 7.4 & 7.6 & 13.8 & 25.0 & 12.6 & 66.5 & 10.8 & 4.0 & 14.8 & 18.7 \\
\hline 74.14 & 5.9 & 16.6 & 31.8 & 28.4 & 7.0 & 89.7 & 1.5 & 3.6 & 5.1 & 5.2 \\
\hline 76.52 & 14.4 & 16.5 & 18.7 & 16.9 & 8.7 & 75.1 & 8.5 & 2.6 & 11.1 & 13.8 \\
\hline 78.81 & 5.4 & 6.4 & 11.4 & 22.6 & 22.3 & 68.2 & 13.5 & 7.4 & 20.9 & 10.9 \\
\hline 81.10 & 15.8 & 17.8 & 22.5 & 18.3 & 6.5 & 80.9 & 6.5 & 3.1 & 9.6 & 9.5 \\
\hline 83.40 & 19.9 & 17.9 & 13.1 & 9.4 & 4.9 & 65.1 & 5.9 & 1.4 & 7.3 & 27.6 \\
\hline 85.84 & 9.1 & 14.6 & 21.9 & 30.1 & 11.9 & 87.5 & 3.8 & 1.4 & 5.2 & 7.3 \\
\hline 88.28 & 4.8 & 8.4 & 16.9 & 32.7 & 15.8 & 78.7 & 8.1 & 5.2 & 13.3 & 8.0 \\
\hline 90.66 & 8.0 & 11.5 & 20.7 & 29.6 & 14.9 & 84.7 & 4.6 & 2.8 & 7.4 & 7.9 \\
\hline 93.22 & 3.9 & 7.3 & 16.4 & 32.9 & 17.9 & 78.6 & 9.4 & 4.0 & 13.4 & 8.0 \\
\hline 95.48 & 5.3 & 10.0 & 21.5 & 31.6 & 14.4 & 82.8 & 6.2 & 2.9 & 9.1 & 8.1 \\
\hline 97.68 & 11.9 & 13.6 & 20.5 & 28.0 & 12.2 & 86.2 & 5.2 & 2.7 & 7.9 & 5.9 \\
\hline 100.33 & 19.0 & 24.2 & 29.4 & 17.1 & 4.7 & 94.4 & 2.6 & 0.5 & 3.1 & $\overline{2.5}$ \\
\hline 104.97 & 17.4 & 21.7 & 23.3 & 13.8 & 6.2 & 82.4 & 6.4 & 0.8 & 7.2 & 10.4 \\
\hline 107.35 & 1.6 & 2.8 & 9.7 & 30.5 & 20.4 & 65.0 & 18.1 & 10.2 & 28.3 & 6.7 \\
\hline 109.88 & 2.0 & 3.1 & 8.0 & 23.5 & 24.1 & 60.7 & 21.4 & 6.8 & 28.2 & 11.1 \\
\hline 112.17 & 9.6 & 16.0 & 27.6 & 28.4 & 9.0 & 90.6 & 3.3 & 1.8 & 5.1 & 4.3 \\
\hline 114.55 & 4.1 & 8.7 & 21.6 & 29.7 & 15.8 & 79.8 & 6.1 & 3.8 & 9.9 & 10.3 \\
\hline 116.87 & 17.3 & 21.5 & 22.6 & 16.5 & 5.7 & 83.7 & 3.3 & 1.1 & 4.4 & 11.9 \\
\hline 119.19 & 4.2 & 6.5 & 15.1 & 24.5 & 15.2 & 65.5 & 11.2 & 3.3 & 14.5 & 20.0 \\
\hline 121.69 & 3.7 & 6.3 & 18.1 & 31.9 & 12.9 & 72.9 & 10.7 & 2.5 & 13.2 & 13.9 \\
\hline 124.07 & 26.0 & 23.8 & 22.9 & 13.9 & 3.5 & 90.0 & 3.0 & 0.6 & 3.6 & 6.4 \\
\hline 126.41 & 8.1 & 13.4 & 21.0 & 25.3 & 14.6 & 82.5 & 5.6 & 4.6 & 10.2 & 7.3 \\
\hline 128.74 & 7.9 & 10.8 & 17.9 & 28.6 & 17.3 & 82.5 & 5.8 & 4.1 & 9.9 & 7.6 \\
\hline 131.28 & 6.9 & 31.4 & 40.8 & 11.3 & 2.4 & 92.9 & 2.6 & 0.6 & 3.2 & 3.9 \\
\hline 135.97 & 18.0 & 20.3 & 25.8 & 19.1 & 5.8 & 88.9 & 4.4 & 2.0 & 6.4 & 4.7 \\
\hline 138.36 & 10.5 & 17.8 & 31.1 & 23.5 & 7.7 & 90.6 & 2.7 & 1.4 & 4.1 & 5.3 \\
\hline 140.78 & 9.1 & 14.8 & 26.7 & 29.7 & 9.7 & 89.9 & 3.3 & 2.7 & 6.0 & 4.1 \\
\hline 142.96 & 14.3 & 15.3 & 20.7 & 22.6 & 10.5 & 83.5 & 6.3 & 3.1 & 9.4 & 7.1 \\
\hline 145.53 & 4.3 & 8.5 & 22.5 & 38.6 & 15.3 & 89.2 & 3.0 & 1.9 & 4.9 & 5.9 \\
\hline 147.08 & 35.0 & 28.3 & 18.8 & 7.5 & 1.8 & 91.5 & 2.1 & 1.0 & 3.1 & 5.4 \\
\hline
\end{tabular}


Table B-3

Bulk Density for U-3at-D1 Characterization Samples

(Depth in meters; density in kilograms per cubic meter)

\begin{tabular}{|c|c|c|c|c|c|}
\hline \multicolumn{2}{|c|}{ Location: U-3at-D1 } & \multicolumn{2}{|c|}{ Analysis: Dry Bulk Density } & \multirow[b]{2}{*}{$\begin{array}{l}\widehat{\Xi} \\
\text { छิ } \\
\text { 흠 }\end{array}$} & \multirow[b]{2}{*}{ 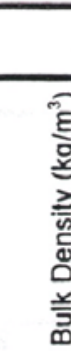 } \\
\hline $\begin{array}{l}\widehat{\underline{E}} \\
\text { 言 } \\
\text { 口. }\end{array}$ & 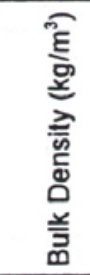 & 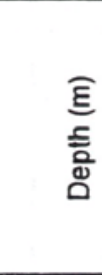 & 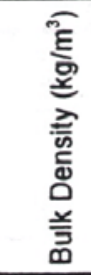 & & \\
\hline$\overline{5.42}$ & 1550 & 56.60 & 1707 & 105.18 & 1580 \\
\hline 5.55 & 1545 & 56.78 & 1540 & 107.44 & 1557 \\
\hline 7.75 & 1783 & 58.52 & 1700 & 107.56 & 1530 \\
\hline 7.81 & 1580 & 58.64 & 1641 & 109.82 & 1413 \\
\hline 10.40 & 1622 & 61.36 & 1540 & 109.88 & 1450 \\
\hline 10.53 & 1420 & 61.43 & 1566 & 112.26 & 1569 \\
\hline 13.18 & 1650 & 66.56 & 1400 & 112.38 & 1650 \\
\hline 13.31 & 1530 & 66.62 & 1552 & 114.64 & 1497 \\
\hline 15.25 & 1508 & 67.06 & 1360 & 114.76 & 1460 \\
\hline 15.37 & 1590 & 67.12 & 1480 & 116.96 & 1836 \\
\hline 17.90 & 1420 & 68.73 & 1773 & 117.08 & 1780 \\
\hline 17.96 & 1454 & 68.85 & 1450 & 119.28 & 1748 \\
\hline 20.35 & 1588 & 71.33 & 1797 & 119.40 & 1560 \\
\hline 20.48 & 1450 & 71.39 & 1860 & 121.78 & 1520 \\
\hline 22.94 & 1510 & 73.99 & 1640 & 121.89 & 1550 \\
\hline 23.00 & 1792 & 74.05 & 1718 & 124.16 & 1721 \\
\hline 25.40 & 1560 & 76.34 & 1490 & 124.28 & 1640 \\
\hline 25.46 & 1727 & 76.52 & 1877 & 126.49 & 1774 \\
\hline 28.08 & 2055 & 78.78 & 1509 & 126.61 & 1670 \\
\hline 28.15 & 1750 & 78.84 & 1560 & 128.83 & 1857 \\
\hline 30.25 & 1480 & 81.04 & 1850 & 128.95 & 1610 \\
\hline 30.31 & 1330 & 81.10 & 1730 & 131.34 & 1592 \\
\hline 32.67 & 1701 & 83.48 & 1442 & 131.46 & 1400 \\
\hline 32.74 & 1610 & 83.60 & 1550 & 133.55 & 1922 \\
\hline 35.16 & 1604 & 86.04 & 1757 & 133.61 & 1410 \\
\hline 35.42 & 1530 & 86.10 & 1630 & 136.06 & 1796 \\
\hline 40.14 & 1856 & 88.37 & 1501 & 136.18 & 1790 \\
\hline 40.26 & 1660 & 88.49 & 1410 & 138.45 & 1578 \\
\hline 42.62 & 1783 & 90.75 & 1702 & 138.57 & 1560 \\
\hline 42.92 & 1640 & 90.87 & 1600 & 140.90 & 1465 \\
\hline 42.96 & 1750 & 93.31 & 1475 & 141.02 & 1550 \\
\hline 46.77 & 1830 & 93.37 & 1430 & 143.05 & 1449 \\
\hline 46.83 & 1490 & 95.33 & 1620 & 143.29 & 1500 \\
\hline 49.20 & 1671 & 95.45 & 1364 & 145.62 & 1591 \\
\hline 49.32 & 1530 & 97.74 & 1560 & 145.74 & 1490 \\
\hline 51.83 & 1446 & 97.89 & 1586 & 147.17 & 1825 \\
\hline 51.96 & 1540 & 100.12 & 1750 & 147.29 & 1520 \\
\hline 54.19 & 1685 & 100.18 & 1410 & & \\
\hline 54.37 & 1480 & 105.06 & 1585 & & \\
\hline
\end{tabular}


Table B-4

Water Retention Relations for U-3at-D1 Characterization Samples

(Depth in meters; volumetric water content $[\theta]$ in cubic meters per cubic meter; matric potential [h] MegaPascals)

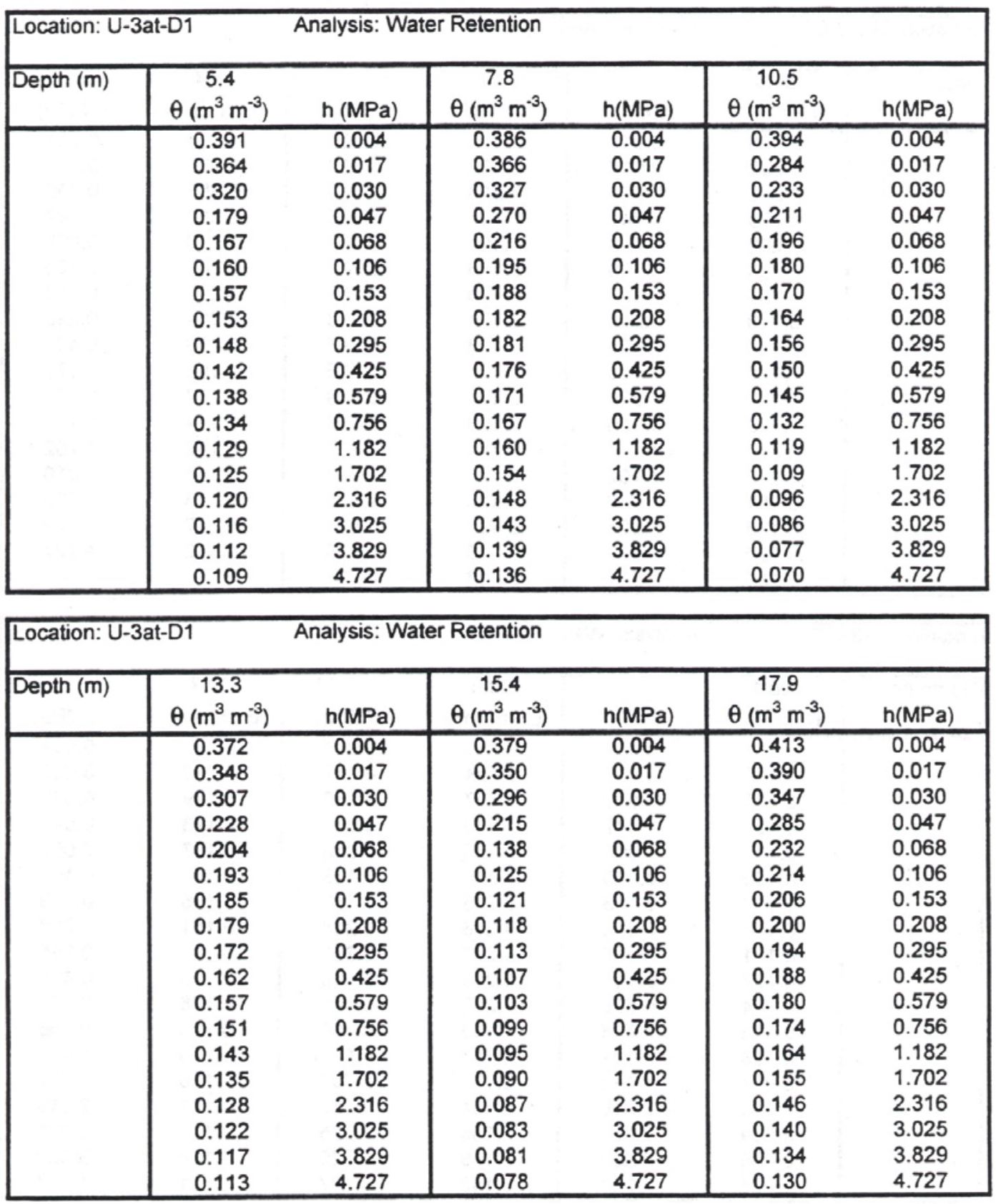




\section{Table B-4}

Water Retention Relations for U-3at-D1 Characterization Samples (continued)

(Depth in meters; volumetric water content $[\theta]$ in cubic meters per cubic meter; matric potential [h] MegaPascals)

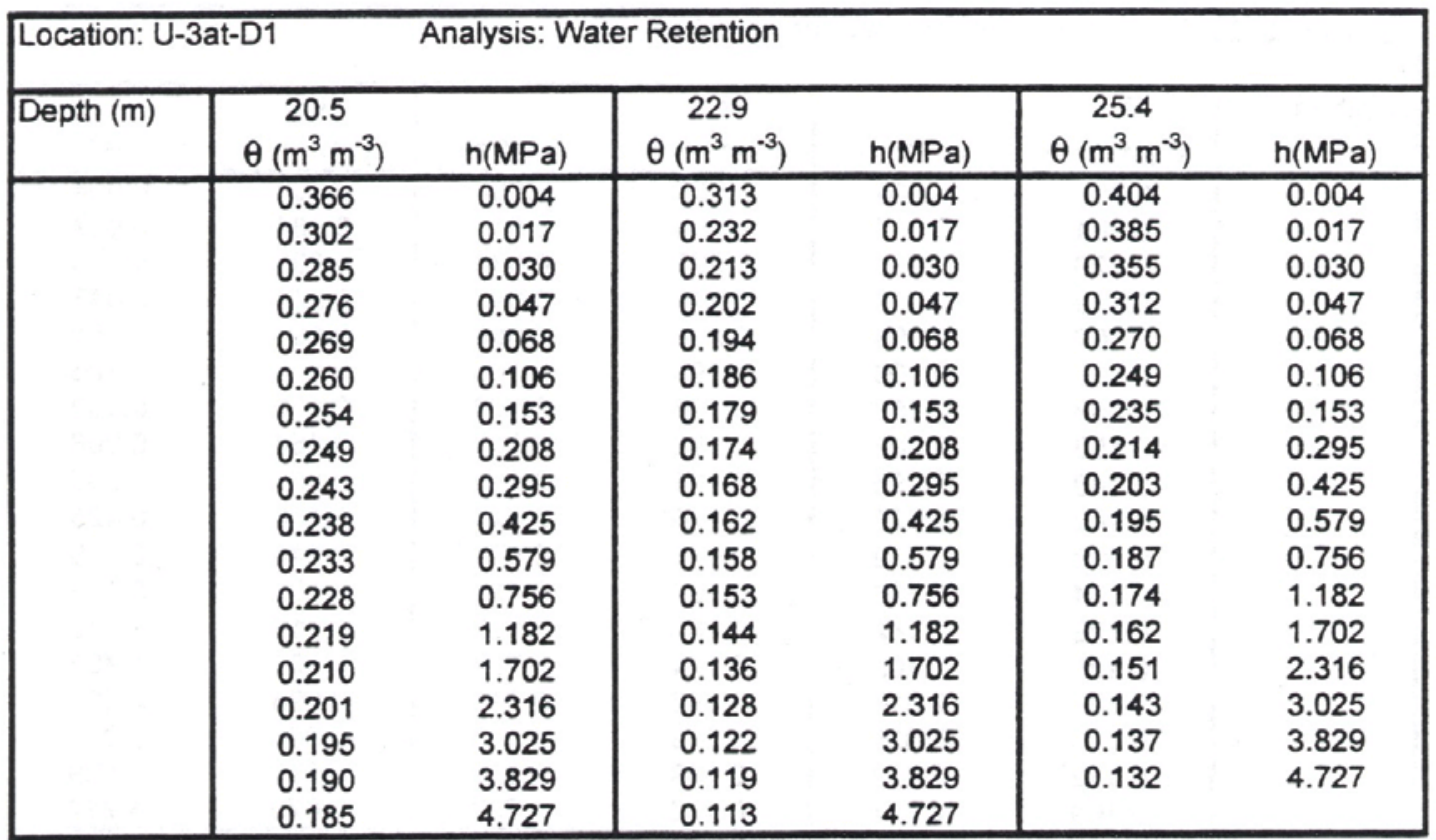

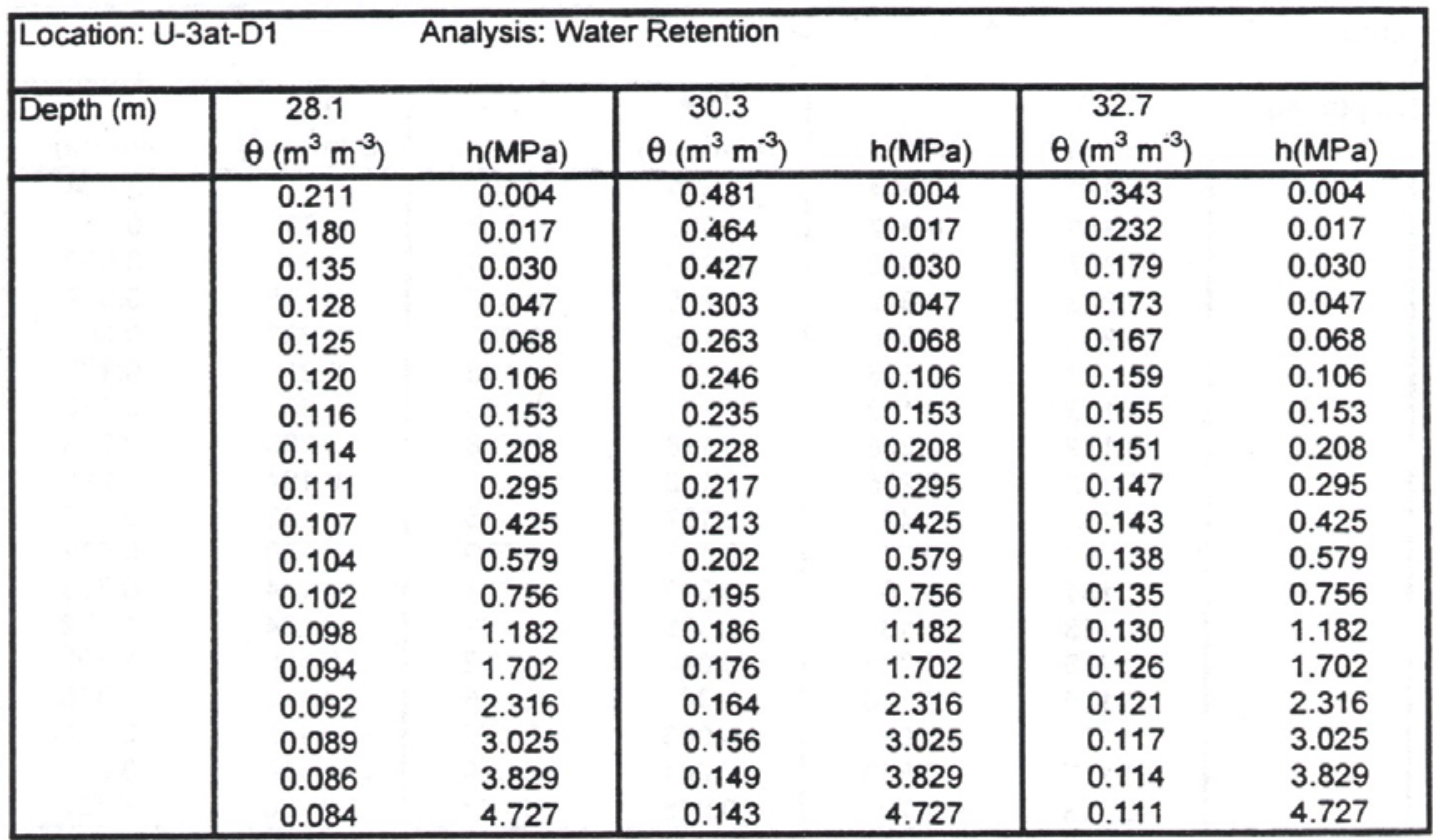


Table B-4

Water Retention Relations for U-3at-D1 Characterization Samples (continued)

(Depth in meters; volumetric water content [ $\theta]$ in cubic meters per cubic meter; matric potential [h] MegaPascals)

\begin{tabular}{|c|c|c|c|c|c|c|}
\hline \multicolumn{2}{|c|}{ Location: U-3at-D1 } & \multicolumn{5}{|c|}{ Analysis: Water Retention } \\
\hline Depth (m) & $\begin{array}{c}35.4 \\
\theta\left(\mathrm{m}^{3} \mathrm{~m}^{-3}\right)\end{array}$ & $\mathrm{h}(\mathrm{MPa})$ & $\begin{array}{c}40.3 \\
\theta\left(\mathrm{m}^{3} \mathrm{~m}^{-3}\right)\end{array}$ & $\mathrm{h}(\mathrm{MPa})$ & $\begin{array}{c}42.9 \\
\theta\left(\mathrm{m}^{3} \mathrm{~m}^{-3}\right)\end{array}$ & $\mathrm{h}(\mathrm{MPa})$ \\
\hline . & $\begin{array}{l}0.302 \\
0.182 \\
0.163 \\
0.153 \\
0.147 \\
0.141 \\
0.136 \\
0.131 \\
0.127 \\
0.122 \\
0.118 \\
0.114 \\
0.109 \\
0.105 \\
0.100 \\
0.096 \\
0.093 \\
0.090\end{array}$ & $\begin{array}{l}0.004 \\
0.017 \\
0.030 \\
0.047 \\
0.068 \\
0.106 \\
0.153 \\
0.208 \\
0.295 \\
0.425 \\
0.579 \\
0.756 \\
1.182 \\
1.702 \\
2.316 \\
3.025 \\
3.829 \\
4.727\end{array}$ & $\begin{array}{l}0.239 \\
0.130 \\
0.121 \\
0.117 \\
0.115 \\
0.111 \\
0.109 \\
0.106 \\
0.103 \\
0.099 \\
0.096 \\
0.094 \\
0.090 \\
0.086 \\
0.083 \\
0.080 \\
0.078 \\
0.075\end{array}$ & $\begin{array}{l}0.004 \\
0.017 \\
0.030 \\
0.047 \\
0.068 \\
0.106 \\
0.153 \\
0.208 \\
0.295 \\
0.425 \\
0.579 \\
0.756 \\
1.182 \\
1.702 \\
2.316 \\
3.025 \\
3.829 \\
4.727 \\
\end{array}$ & $\begin{array}{l}0.277 \\
0.254 \\
0.245 \\
0.239 \\
0.234 \\
0.226 \\
0.219 \\
0.213 \\
0.206 \\
0.196 \\
0.186 \\
0.179 \\
0.168 \\
0.159 \\
0.152 \\
0.145 \\
0.140 \\
0.135 \\
\end{array}$ & $\begin{array}{l}0.004 \\
0.017 \\
0.030 \\
0.047 \\
0.068 \\
0.106 \\
0.153 \\
0.208 \\
0.295 \\
0.425 \\
0.579 \\
0.756 \\
1.182 \\
1.702 \\
2.316 \\
3.025 \\
3.829 \\
4.727 \\
\end{array}$ \\
\hline
\end{tabular}

\begin{tabular}{|c|c|c|c|c|c|c|}
\hline \multicolumn{7}{|c|}{ Location: U-3at-D1 } \\
\hline Depth (m) & $\begin{array}{c}43.0 \\
\theta\left(\mathrm{m}^{3} \mathrm{~m}^{-3}\right)\end{array}$ & h(MPa) & $\begin{array}{c}46.8 \\
\theta\left(\mathrm{m}^{3} \mathrm{~m}^{-3}\right) \\
\end{array}$ & $\mathrm{h}(\mathrm{MPa})$ & $\begin{array}{c}49.3 \\
\theta\left(\mathrm{m}^{3} \mathrm{~m}^{-3}\right)\end{array}$ & $\mathrm{h}(\mathrm{MPa})$ \\
\hline & $\begin{array}{l}0.285 \\
0.225 \\
0.128 \\
0.120 \\
0.116 \\
0.112 \\
0.108 \\
0.104 \\
0.101 \\
0.098 \\
0.095 \\
0.093 \\
0.090 \\
0.087 \\
0.085 \\
0.082 \\
0.080 \\
0.078\end{array}$ & $\begin{array}{l}0.004 \\
0.017 \\
0.030 \\
0.047 \\
0.068 \\
0.106 \\
0.153 \\
0.208 \\
0.295 \\
0.425 \\
0.579 \\
0.756 \\
1.182 \\
1.702 \\
2.316 \\
3.025 \\
3.829 \\
4.727 \\
\end{array}$ & $\begin{array}{l}0.289 \\
0.240 \\
0.199 \\
0.190 \\
0.187 \\
0.179 \\
0.172 \\
0.167 \\
0.162 \\
0.156 \\
0.150 \\
0.145 \\
0.138 \\
0.132 \\
0.125 \\
0.120 \\
0.116 \\
0.112 \\
\end{array}$ & $\begin{array}{l}0.004 \\
0.017 \\
0.030 \\
0.047 \\
0.068 \\
0.106 \\
0.153 \\
0.208 \\
0.295 \\
0.425 \\
0.579 \\
0.756 \\
1.182 \\
1.702 \\
2.316 \\
3.025 \\
3.829 \\
4.727 \\
\end{array}$ & $\begin{array}{l}0.407 \\
0.392 \\
0.353 \\
0.286 \\
0.219 \\
0.195 \\
0.186 \\
0.180 \\
0.175 \\
0.170 \\
0.163 \\
0.157 \\
0.151 \\
0.145 \\
0.138 \\
0.131 \\
0.126 \\
0.121 \\
\end{array}$ & $\begin{array}{l}0.004 \\
0.017 \\
0.030 \\
0.047 \\
0.068 \\
0.106 \\
0.153 \\
0.208 \\
0.295 \\
0.425 \\
0.579 \\
0.756 \\
1.182 \\
1.702 \\
2.316 \\
3.025 \\
3.829 \\
4.727 \\
\end{array}$ \\
\hline
\end{tabular}


Table B-4

Water Retention Relations for U-3at-D1 Characterization Samples (continued)

(Depth in meters; volumetric water content [ $\theta]$ in cubic meters per cubic meter; matric potential [h] MegaPascals)

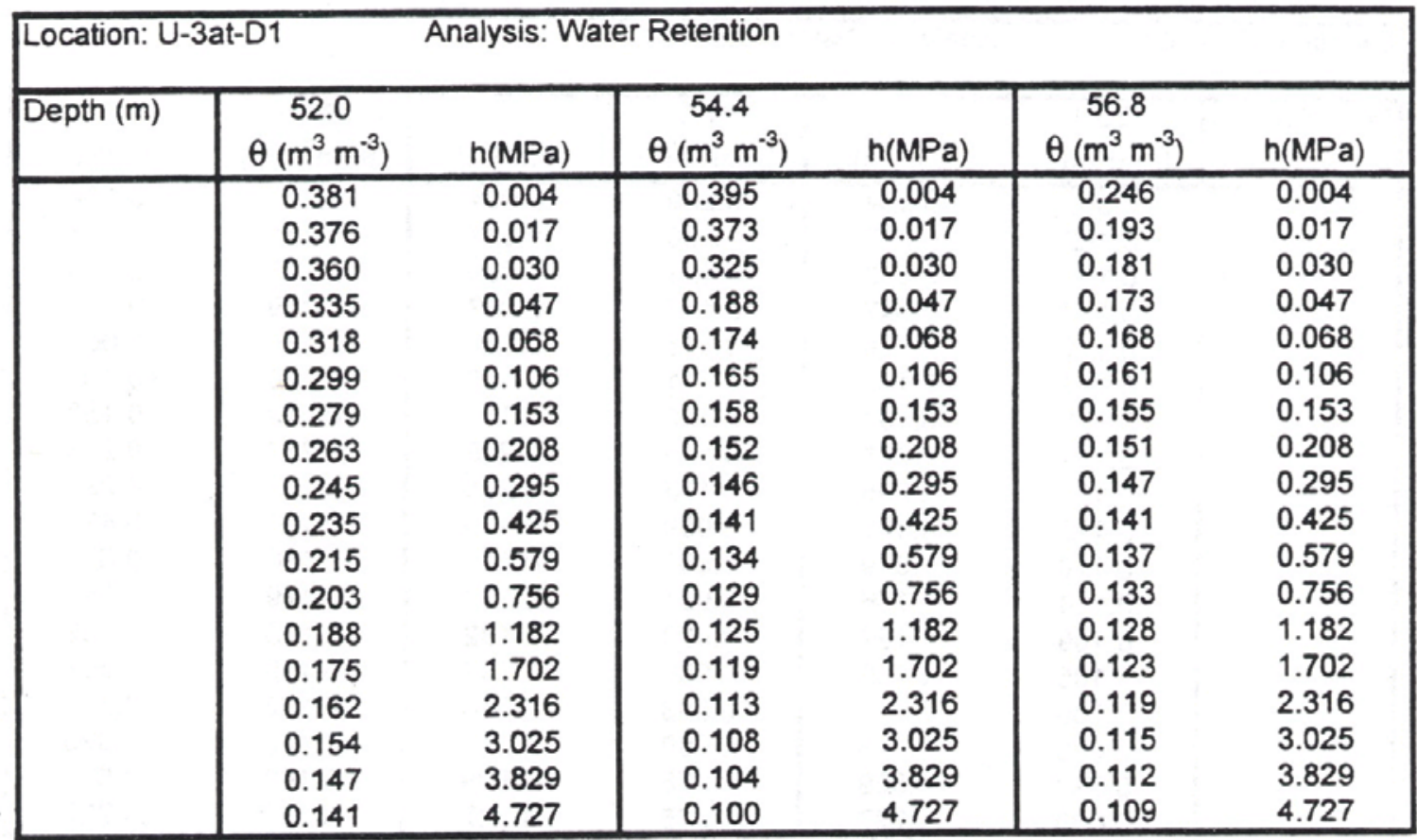

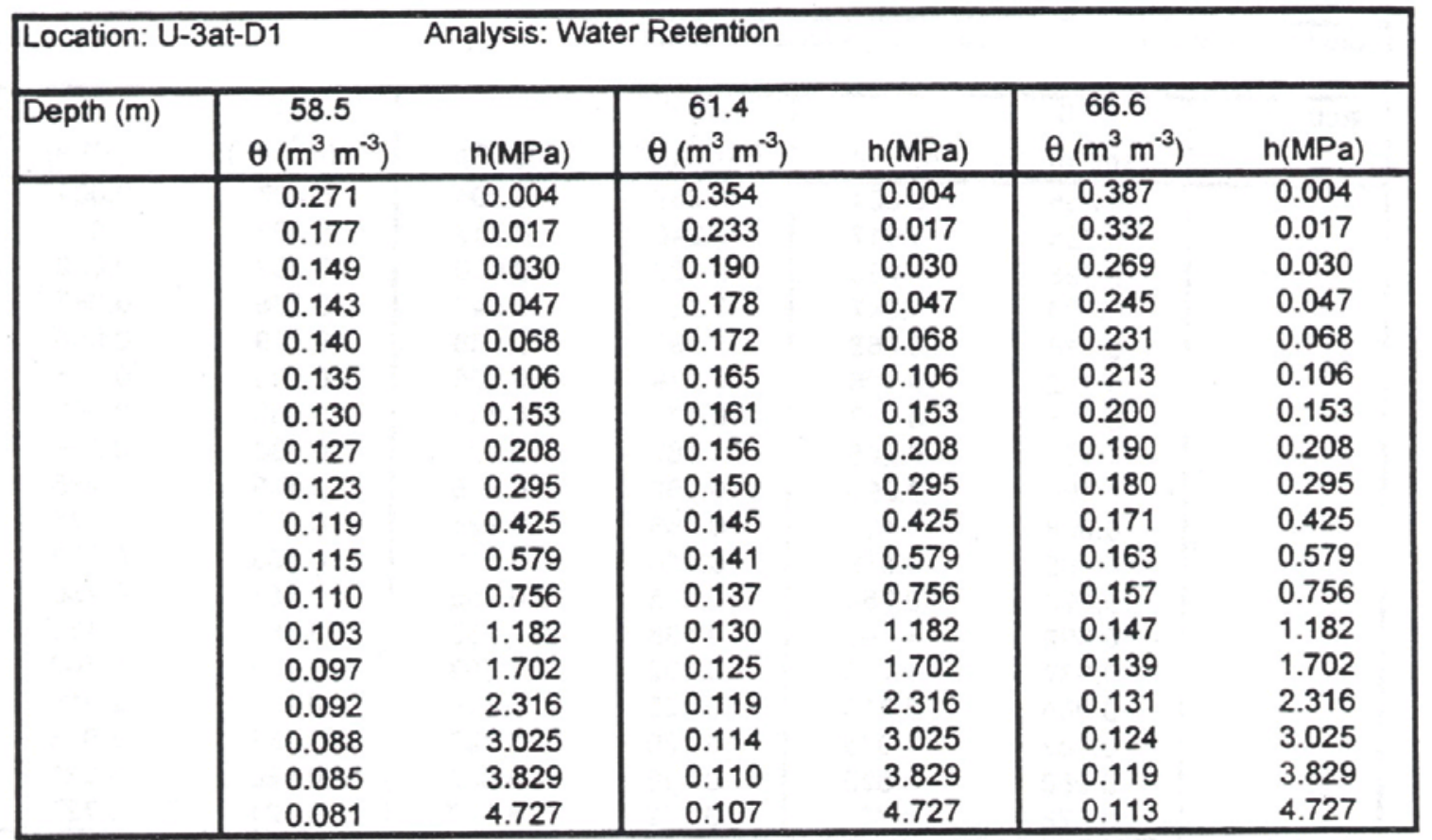




\section{Table B-4}

Water Retention Relations for U-3at-D1 Characterization Samples (continued)

(Depth in meters; volumetric water content $[\theta]$ in cubic meters per cubic meter; matric potential [h] MegaPascals)

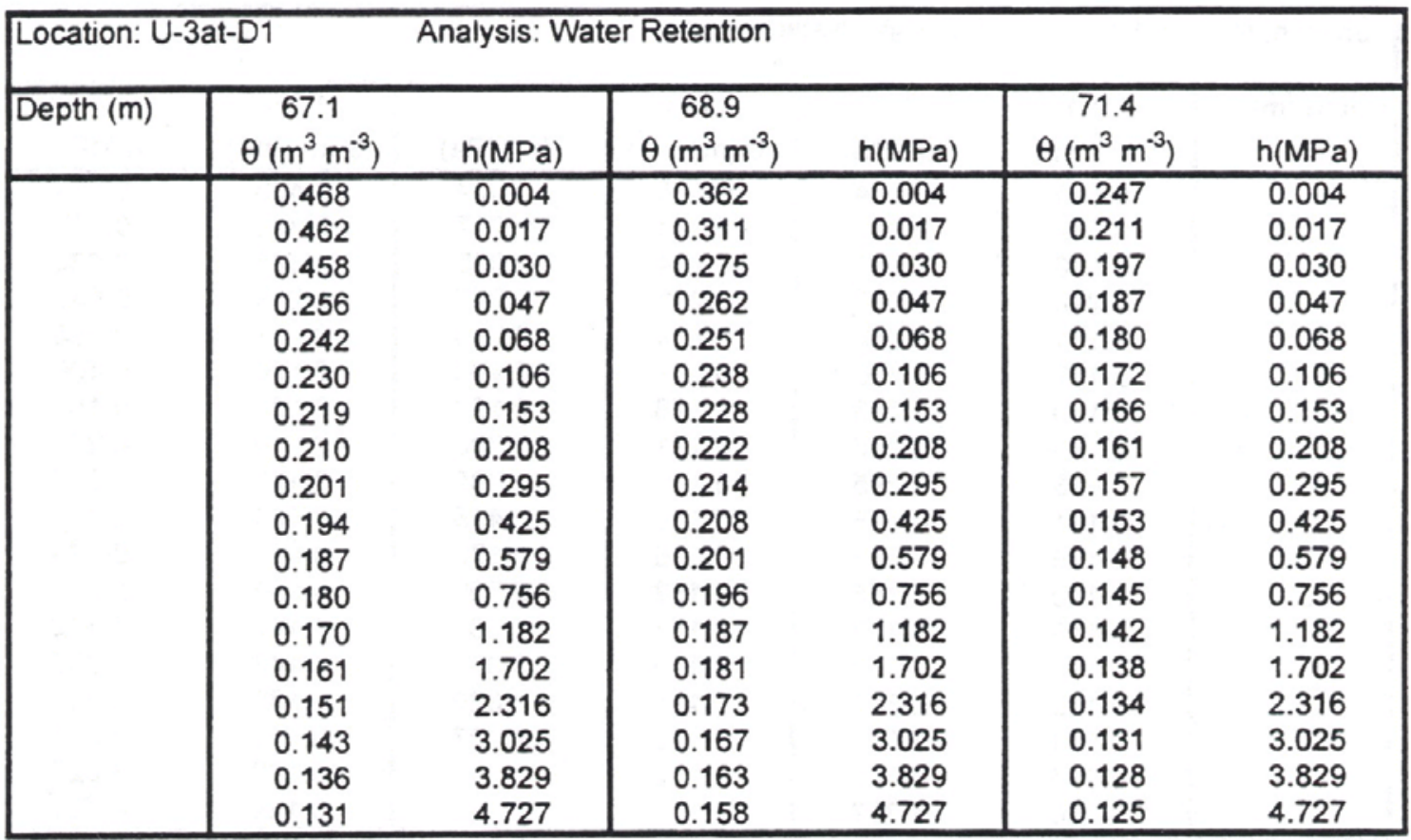

\begin{tabular}{|c|c|c|c|c|c|c|}
\hline \multicolumn{7}{|c|}{ Location: U-3at-D1 } \\
\hline Depth (m) & $\begin{array}{c}74.0 \\
\theta\left(\mathrm{m}^{3} \mathrm{~m}^{-3}\right)\end{array}$ & $h(M P a)$ & $\begin{array}{c}76.3 \\
\theta\left(m^{3} m^{-3}\right)\end{array}$ & $h(\mathrm{MPa})$ & $\begin{array}{c}78.8 \\
\theta\left(m^{3} m^{-3}\right)\end{array}$ & $\mathrm{h}(\mathrm{MPa})$ \\
\hline & $\begin{array}{l}0.314 \\
0.235 \\
0.203 \\
0.188 \\
0.180 \\
0.170 \\
0.160 \\
0.156 \\
0.150 \\
0.144 \\
0.138 \\
0.132 \\
0.124 \\
0.118 \\
0.113 \\
0.109 \\
0.105 \\
0.101\end{array}$ & $\begin{array}{l}0.004 \\
0.017 \\
0.030 \\
0.047 \\
0.068 \\
0.106 \\
0.153 \\
0.208 \\
0.295 \\
0.425 \\
0.579 \\
0.756 \\
1.182 \\
1.702 \\
2.316 \\
3.025 \\
3.829 \\
4.727\end{array}$ & $\begin{array}{l}0.373 \\
0.325 \\
0.242 \\
0.225 \\
0.219 \\
0.210 \\
0.204 \\
0.198 \\
0.193 \\
0.187 \\
0.182 \\
0.178 \\
0.172 \\
0.167 \\
0.160 \\
0.156 \\
0.151 \\
0.147\end{array}$ & $\begin{array}{l}0.004 \\
0.017 \\
0.030 \\
0.047 \\
0.068 \\
0.106 \\
0.153 \\
0.208 \\
0.295 \\
0.425 \\
0.579 \\
0.756 \\
1.182 \\
1.702 \\
2.316 \\
3.025 \\
3.829 \\
4.727 \\
\end{array}$ & $\begin{array}{l}0.380 \\
0.360 \\
0.321 \\
0.272 \\
0.229 \\
0.211 \\
0.201 \\
0.193 \\
0.184 \\
0.176 \\
0.169 \\
0.162 \\
0.150 \\
0.140 \\
0.131 \\
0.124 \\
0.118 \\
0.113\end{array}$ & $\begin{array}{l}0.004 \\
0.017 \\
0.030 \\
0.047 \\
0.068 \\
0.106 \\
0.153 \\
0.208 \\
0.295 \\
0.425 \\
0.579 \\
0.756 \\
1.182 \\
1.702 \\
2.316 \\
3.025 \\
3.829 \\
4.727\end{array}$ \\
\hline
\end{tabular}




\section{Table B-4}

Water Retention Relations for U-3at-D1 Characterization Samples (continued)

(Depth in meters; volumetric water content [ $\theta]$ in cubic meters per cubic meter; matric potential [h] MegaPascals)

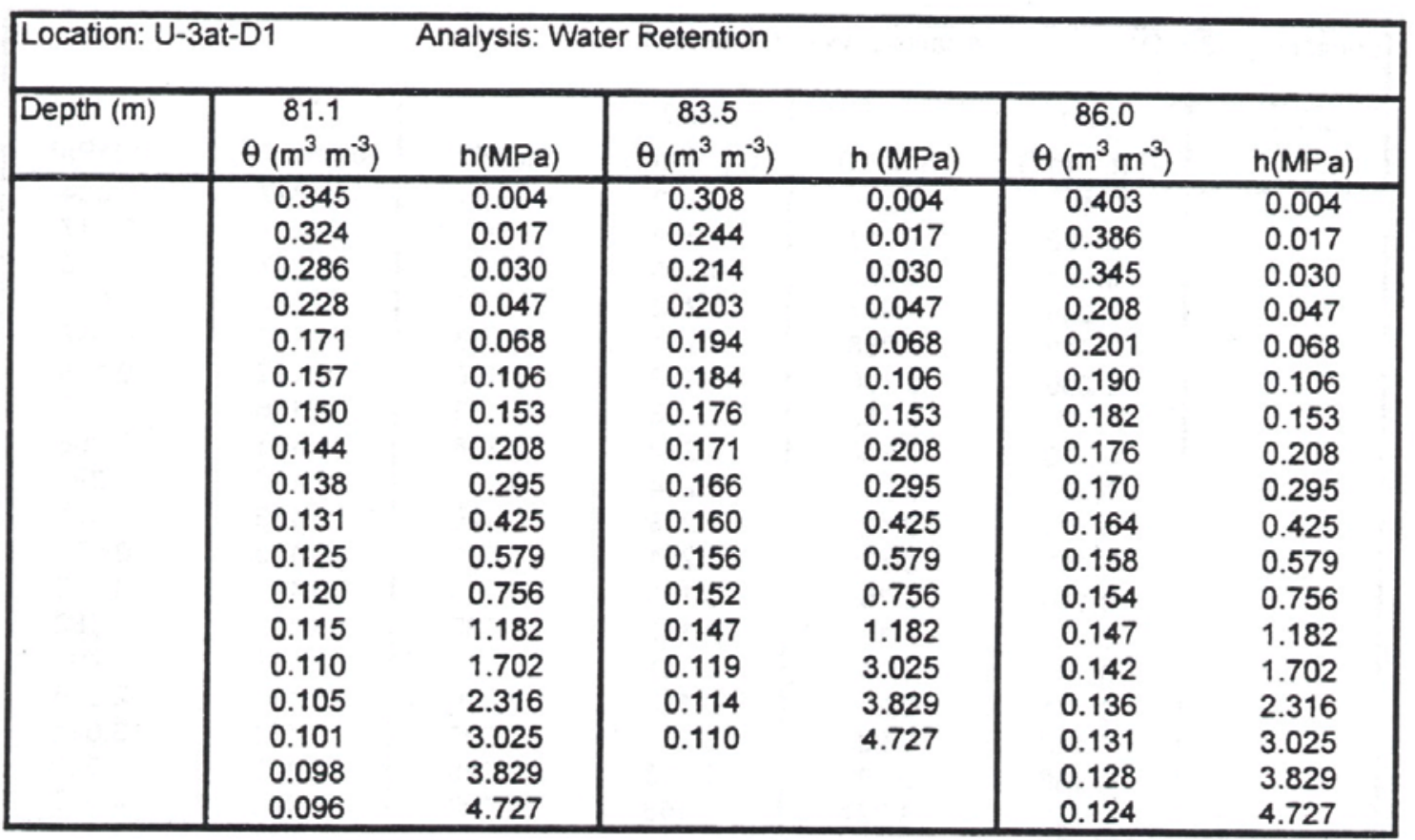

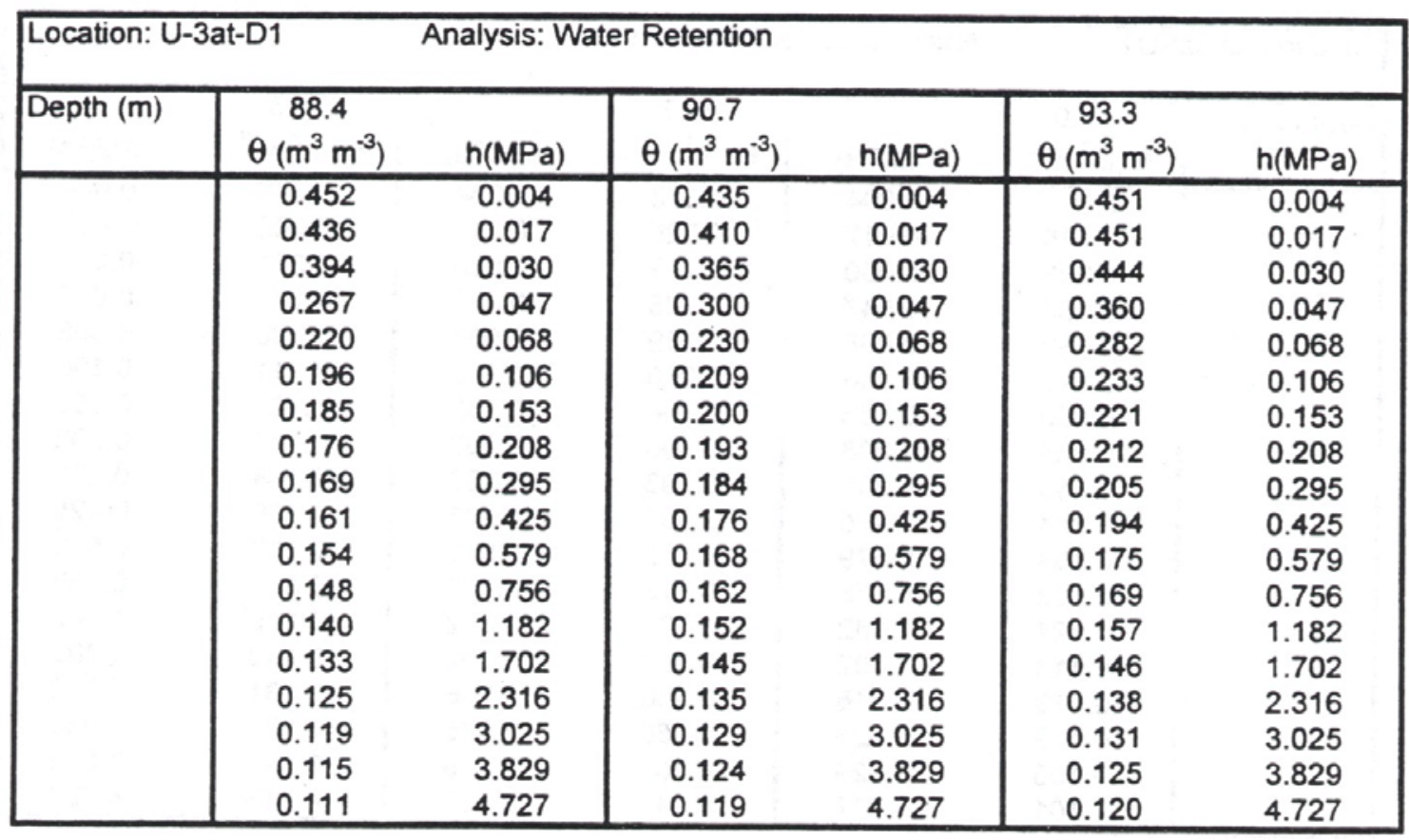




\section{Table B-4}

Water Retention Relations for U-3at-D1 Characterization Samples (continued)

(Depth in meters; volumetric water content $[\theta]$ in cubic meters per cubic meter; matric potential [h] MegaPascals)

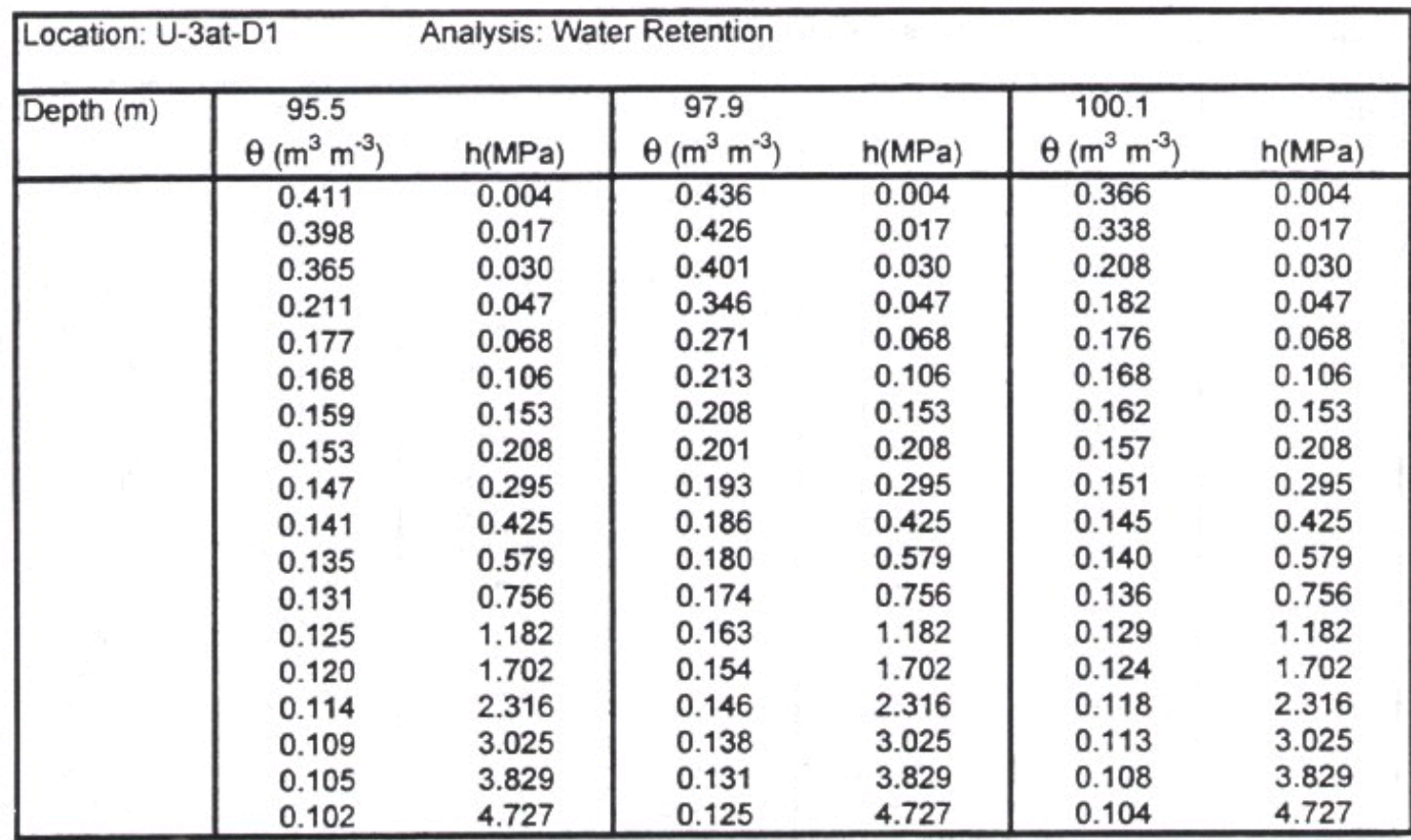

\begin{tabular}{|c|c|c|c|c|c|c|}
\hline \multicolumn{7}{|c|}{ Location: U-3at-D1 } \\
\hline Depth (m) & $\begin{array}{c}105.1 \\
\theta\left(\mathrm{m}^{3} \mathrm{~m}^{-3}\right) \\
\end{array}$ & $h(\mathrm{MPa})$ & $\begin{array}{c}107.4 \\
\theta\left(\mathrm{m}^{3} \mathrm{~m}^{-3}\right) \\
\end{array}$ & $\mathrm{h}(\mathrm{MPa})$ & $\begin{array}{c}109.8 \\
\theta\left(\mathrm{m}^{3} \mathrm{~m}^{-3}\right) \\
\end{array}$ & $\mathrm{h}(\mathrm{MPa})$ \\
\hline & $\begin{array}{l}0.411 \\
0.404 \\
0.383 \\
0.343 \\
0.333 \\
0.317 \\
0.304 \\
0.294 \\
0.282 \\
0.259 \\
0.249 \\
0.234 \\
0.220 \\
0.208 \\
0.199 \\
0.192 \\
0.185\end{array}$ & $\begin{array}{l}0.004 \\
0.017 \\
0.030 \\
0.047 \\
0.068 \\
0.106 \\
0.153 \\
0.208 \\
0.295 \\
0.579 \\
0.756 \\
1.182 \\
1.702 \\
2.316 \\
3.025 \\
3.829 \\
4.727\end{array}$ & $\begin{array}{l}0.418 \\
0.408 \\
0.367 \\
0.268 \\
0.231 \\
0.210 \\
0.195 \\
0.185 \\
0.175 \\
0.165 \\
0.159 \\
0.153 \\
0.143 \\
0.136 \\
0.130 \\
0.124 \\
0.119 \\
0.115\end{array}$ & $\begin{array}{l}0.004 \\
0.017 \\
0.030 \\
0.047 \\
0.068 \\
0.106 \\
0.153 \\
0.208 \\
0.295 \\
0.425 \\
0.579 \\
0.756 \\
1.182 \\
1.702 \\
2.316 \\
3.025 \\
3.829 \\
4.727\end{array}$ & $\begin{array}{l}0.449 \\
0.439 \\
0.418 \\
0.371 \\
0.350 \\
0.323 \\
0.299 \\
0.282 \\
0.264 \\
0.248 \\
0.235 \\
0.226 \\
0.205 \\
0.190 \\
0.178 \\
0.169 \\
0.160 \\
0.153\end{array}$ & $\begin{array}{l}0.004 \\
0.017 \\
0.030 \\
0.047 \\
0.068 \\
0.106 \\
0.153 \\
0.208 \\
0.295 \\
0.425 \\
0.579 \\
0.756 \\
1.182 \\
1.702 \\
2.316 \\
3.025 \\
3.829 \\
4.727\end{array}$ \\
\hline
\end{tabular}




\section{Table B-4}

Water Retention Relations for U-3at-D1 Characterization Samples (continued)

(Depth in meters; volumetric water content $[\theta]$ in cubic meters per cubic meter; matric potential [h] MegaPascals)

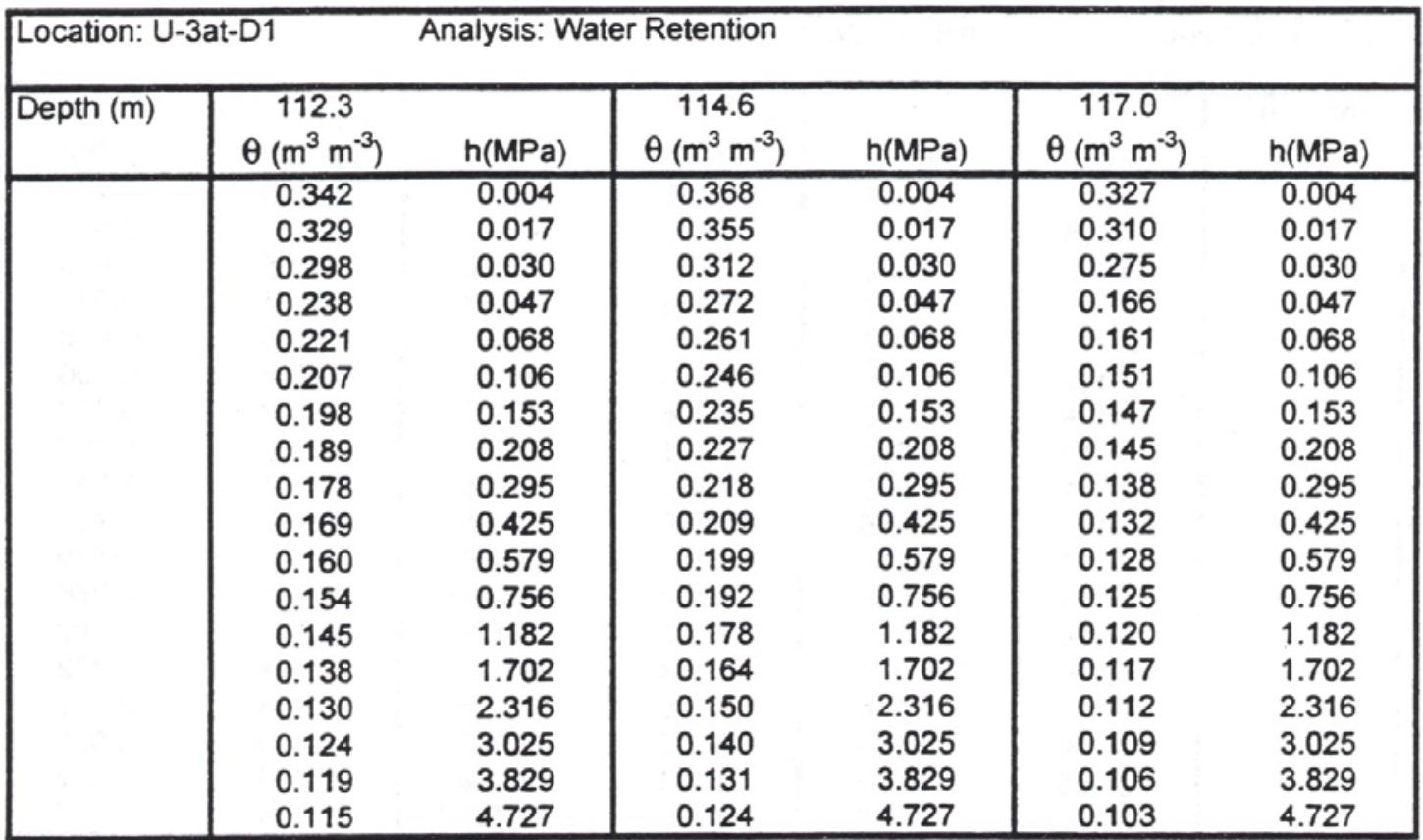

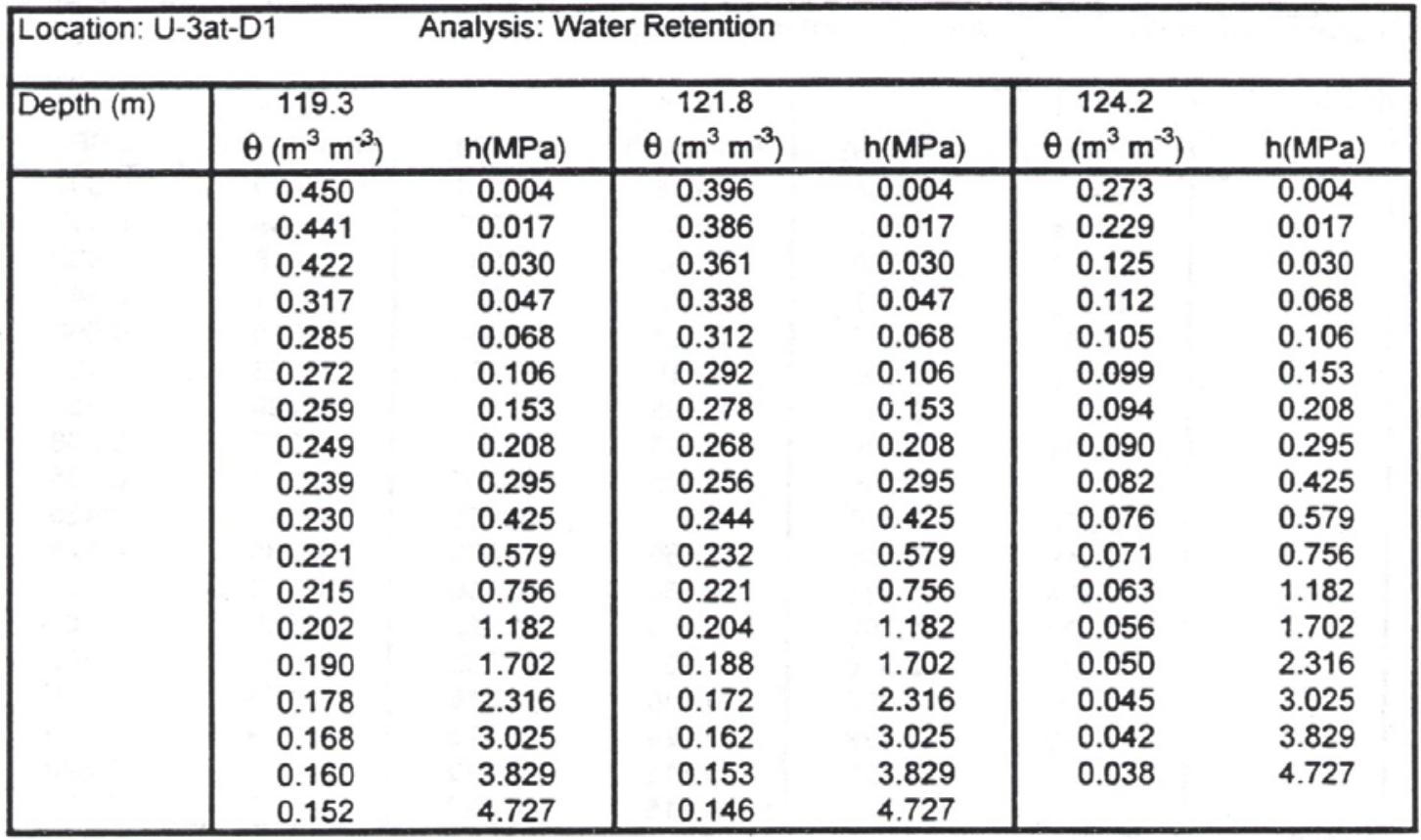




\section{Table B-4}

Water Retention Relations for U-3at-D1 Characterization Samples (continued)

(Depth in meters; volumetric water content $[\theta]$ in cubic meters per cubic meter; matric potential [h] MegaPascals)

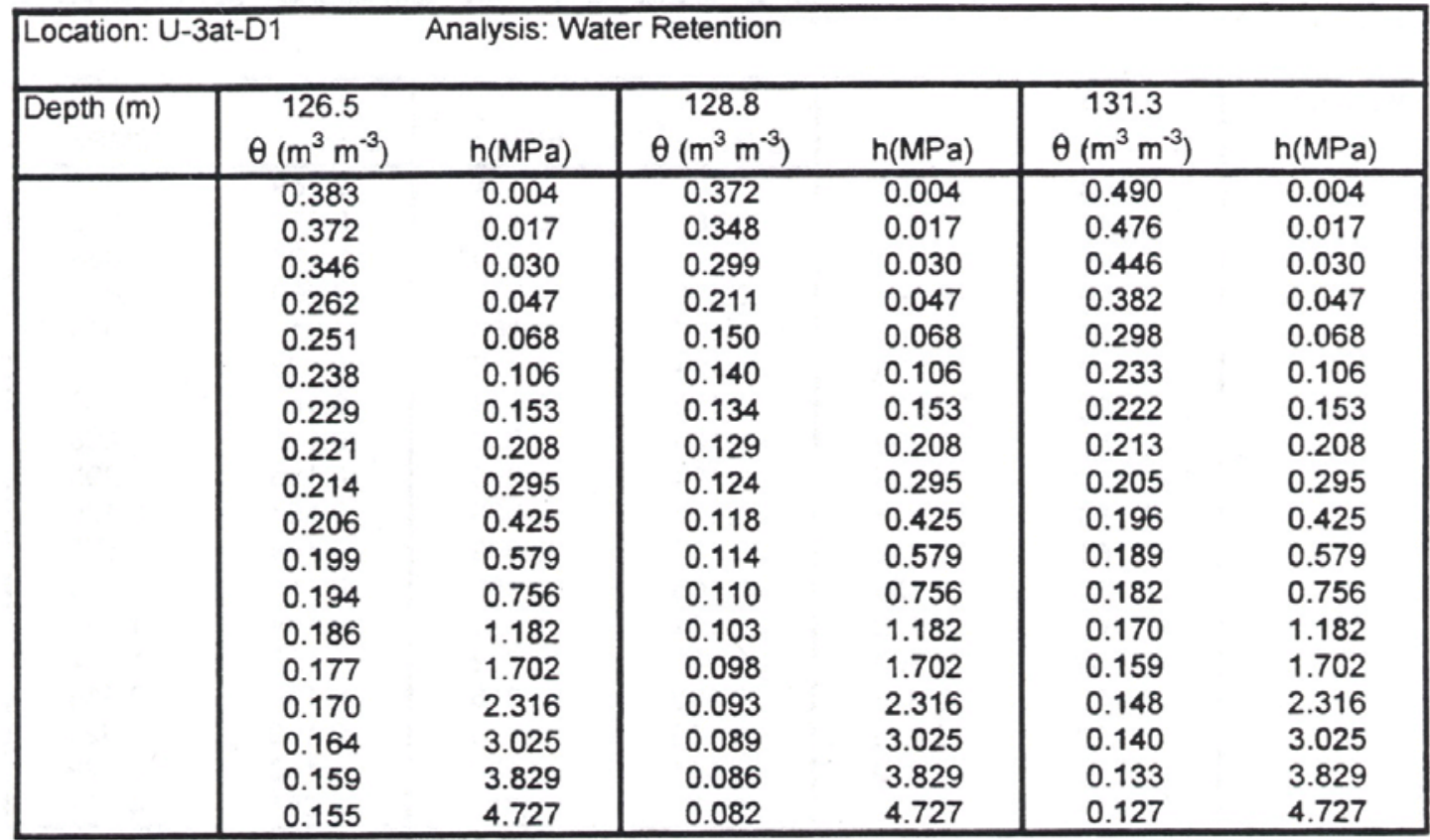

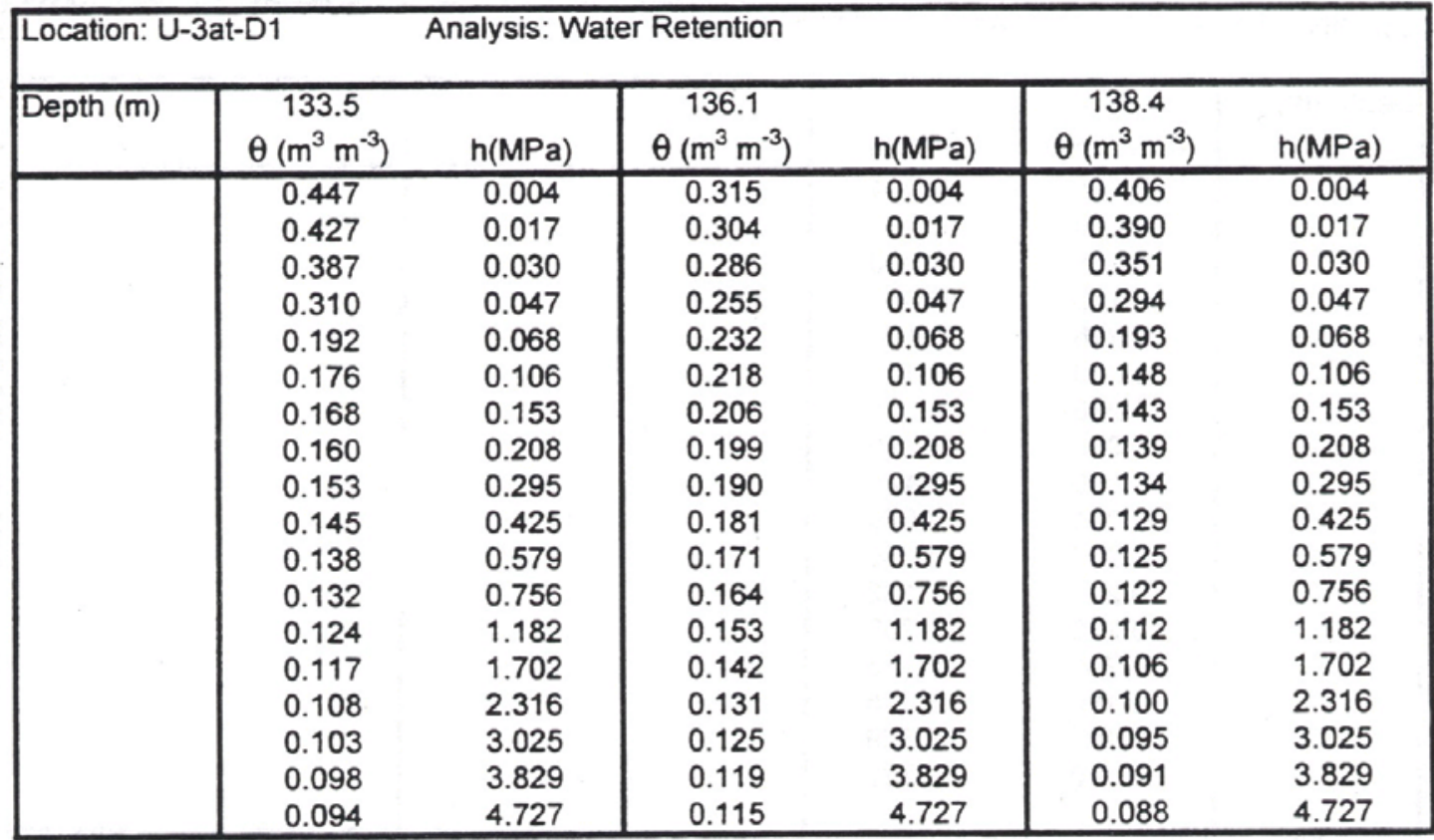




\section{Table B-4}

Water Retention Relations for U-3at-D1 Characterization Samples (continued)

(Depth in meters; volumetric water content $[\theta]$ in cubic meters per cubic meter; matric potential [h] MegaPascals)

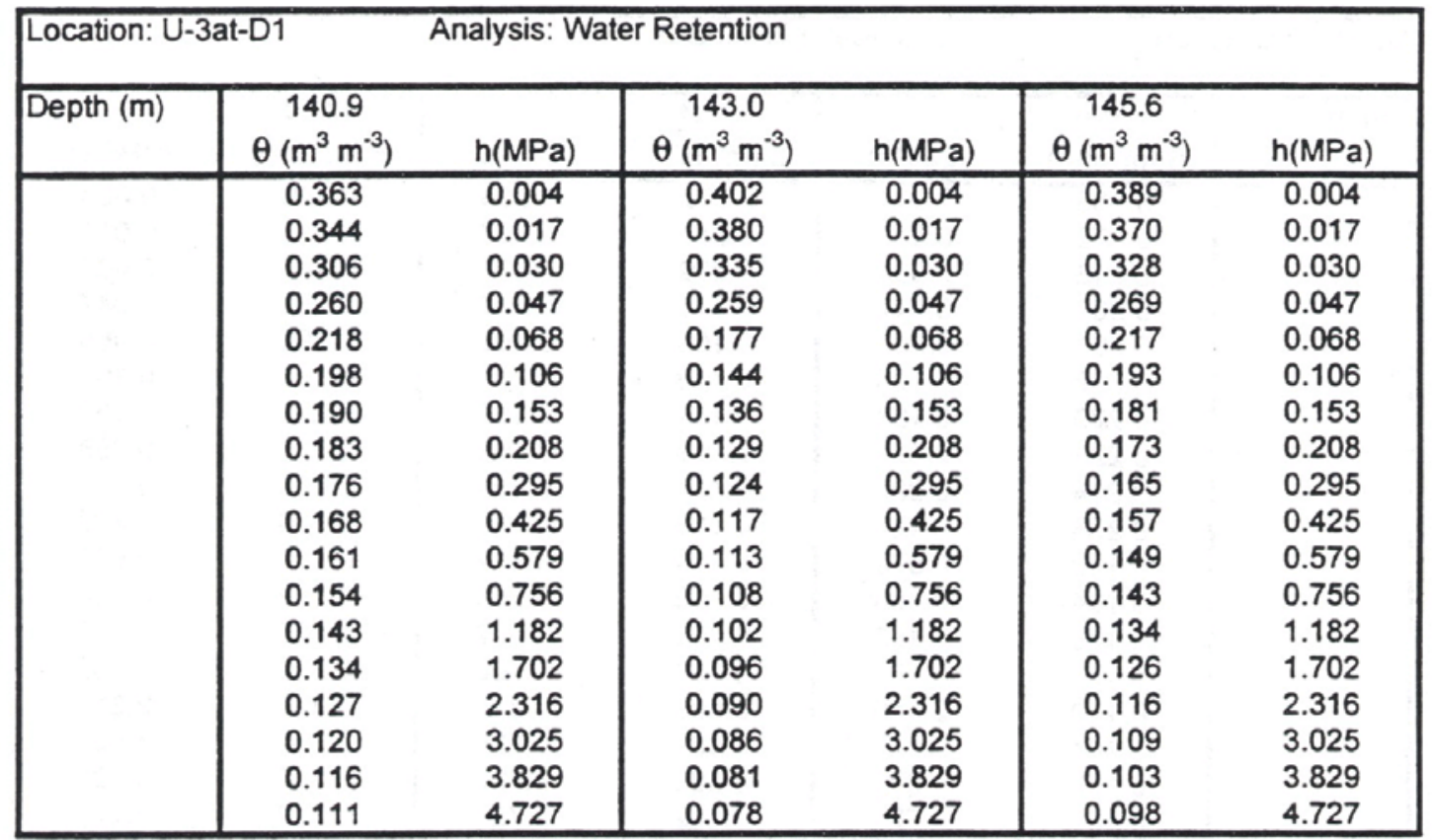

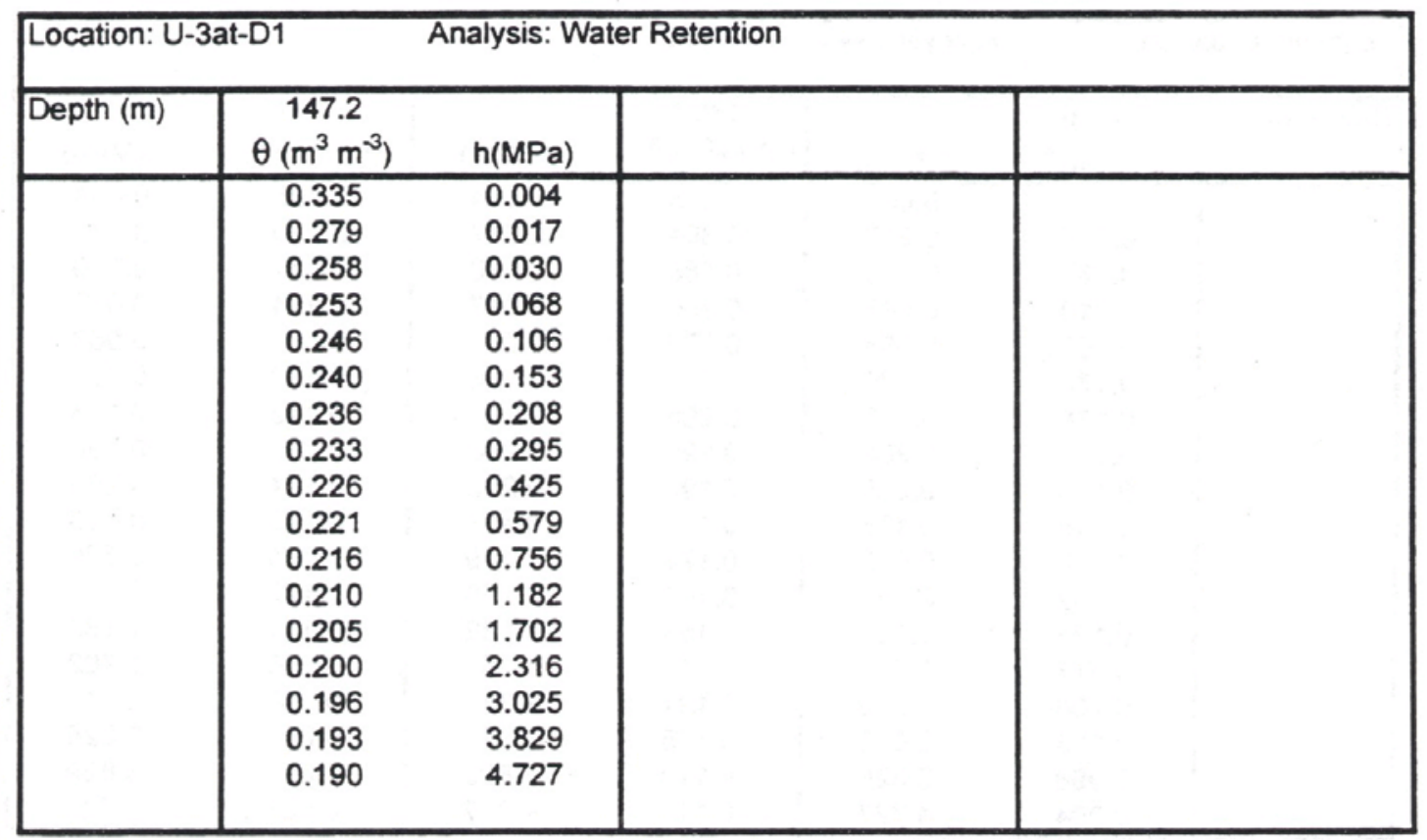


Table B-5

Hydraulic Conductivity I Water Content Relations for U-3at-D1 Characterization Samples

(Depth in meters; volumetric water content $[\theta]$ in cubic meters per cubic meter; hydraulic conductivity $[\mathrm{K}]$ in meters per second)

\begin{tabular}{|l|cc|cc|cc|}
\hline Location: U-3at-D1 17 & \multicolumn{1}{c|}{ Analysis: Hydraulic Conductivity } \\
\hline Depth $(\mathrm{m})$ & $\begin{array}{c}5.4 \\
\theta\left(\mathrm{m}^{3} \mathrm{~m}^{-3}\right)\end{array}$ & $\mathrm{K}(\mathrm{m} / \mathrm{s})$ & $\theta\left(\mathrm{m}^{3} \mathrm{~m}^{-3}\right)$ & $\mathrm{K}(\mathrm{m} / \mathrm{s})$ & $\theta\left(\mathrm{m}^{3} \mathrm{~m}^{-3}\right)$ & $\mathrm{K}(\mathrm{m} / \mathrm{s})$ \\
\hline & 0.328 & $1.29 \mathrm{E}-05$ & 0.397 & $1.94 \mathrm{E}-05$ & 0.443 & $2.67 \mathrm{E}-05$ \\
& 0.320 & $9.61 \mathrm{E}-06$ & 0.383 & $6.16 \mathrm{E}-06$ & 0.425 & $7.10 \mathrm{E}-06$ \\
& 0.292 & $1.58 \mathrm{E}-06$ & 0.375 & $1.58 \mathrm{E}-06$ & 0.415 & $1.58 \mathrm{E}-06$ \\
& 0.285 & $3.96 \mathrm{E}-07$ & 0.356 & $3.96 \mathrm{E}-07$ & 0.337 & $3.96 \mathrm{E}-07$ \\
& 0.234 & $1.43 \mathrm{E}-07$ & 0.274 & $1.43 \mathrm{E}-07$ & 0.285 & $1.43 \mathrm{E}-07$ \\
& 0.208 & $6.33 \mathrm{E}-08$ & 0.253 & $6.33 \mathrm{E}-08$ & 0.241 & $6.33 \mathrm{E}-08$ \\
& 0.196 & $2.85 \mathrm{E}-08$ & 0.234 & $2.85 \mathrm{E}-08$ & 0.226 & $2.85 \mathrm{E}-08$ \\
& 0.188 & $1.07 \mathrm{E}-08$ & 0.229 & $1.07 \mathrm{E}-08$ & 0.208 & $1.07 \mathrm{E}-08$ \\
& 0.183 & $3.56 \mathrm{E}-09$ & 0.222 & $3.56 \mathrm{E}-09$ & 0.195 & $3.56 \mathrm{E}-09$ \\
& 0.174 & $7.13 \mathrm{E}-10$ & 0.209 & $7.13 \mathrm{E}-10$ & 0.188 & $7.13 \mathrm{E}-10$ \\
& 0.167 & $2.69 \mathrm{E}-10$ & 0.202 & $2.69 \mathrm{E}-10$ & 0.178 & $2.69 \mathrm{E}-10$ \\
& 0.158 & $4.56 \mathrm{E}-11$ & 0.190 & $4.56 \mathrm{E}-11$ & 0.164 & $5.39 \mathrm{E}-11$ \\
& 0.143 & $2.50 \mathrm{E}-12$ & 0.178 & $3.60 \mathrm{E}-12$ & 0.153 & $3.60 \mathrm{E}-12$ \\
\hline
\end{tabular}

\begin{tabular}{|c|c|c|c|c|c|c|}
\hline \multicolumn{7}{|c|}{ Analysis: Hydraulic Conductivity } \\
\hline Depth (m) & $\begin{array}{c}13.3 \\
\theta\left(\mathrm{m}^{3} \mathrm{~m}^{-3}\right)\end{array}$ & $\mathrm{K}(\mathrm{m} / \mathrm{s})$ & $\begin{array}{c}15.4 \\
\theta\left(\mathrm{m}^{3} \mathrm{~m}^{-3}\right)\end{array}$ & $\mathrm{K}(\mathrm{m} / \mathrm{s})$ & $\begin{array}{c}17.9 \\
\theta\left(\mathrm{m}^{3} \mathrm{~m}^{-3}\right)\end{array}$ & $\mathrm{K}(\mathrm{m} / \mathrm{s})$ \\
\hline & $\begin{array}{l}0.420 \\
0.393 \\
0.372 \\
0.296 \\
0.263 \\
0.239 \\
0.231 \\
0.223 \\
0.206 \\
0.194 \\
0.175 \\
0.170\end{array}$ & $\begin{array}{l}3.38 \mathrm{E}-06 \\
1.58 \mathrm{E}-06 \\
3.96 \mathrm{E}-07 \\
1.43 \mathrm{E}-07 \\
6.33 \mathrm{E}-08 \\
2.85 \mathrm{E}-08 \\
1.07 \mathrm{E}-08 \\
3.56 \mathrm{E}-09 \\
7.13 \mathrm{E}-10 \\
2.69 \mathrm{E}-10 \\
4.56 \mathrm{E}-11 \\
3.60 \mathrm{E}-12\end{array}$ & $\begin{array}{l}0.335 \\
0.308 \\
0.217 \\
0.191 \\
0.168 \\
0.164 \\
0.145 \\
0.140 \\
0.116 \\
0.112 \\
0.107\end{array}$ & $\begin{array}{l}3.46 \mathrm{E}-06 \\
3.96 \mathrm{E}-07 \\
1.43 \mathrm{E}-07 \\
6.33 \mathrm{E}-08 \\
2.85 \mathrm{E}-08 \\
1.07 \mathrm{E}-08 \\
3.56 \mathrm{E}-09 \\
7.13 \mathrm{E}-10 \\
2.69 \mathrm{E}-10 \\
4.56 \mathrm{E}-11 \\
3.17 \mathrm{E}-12\end{array}$ & $\begin{array}{l}0.428 \\
0.386 \\
0.354 \\
0.287 \\
0.269 \\
0.248 \\
0.237 \\
0.226 \\
0.219 \\
0.208 \\
0.196 \\
0.185\end{array}$ & $\begin{array}{l}1.68 \mathrm{E}-05 \\
1.58 \mathrm{E}-06 \\
3.96 \mathrm{E}-07 \\
1.43 \mathrm{E}-07 \\
6.33 \mathrm{E}-08 \\
2.85 \mathrm{E}-08 \\
1.07 \mathrm{E}-08 \\
3.56 \mathrm{E}-09 \\
7.13 \mathrm{E}-10 \\
2.69 \mathrm{E}-10 \\
4.56 \mathrm{E}-11 \\
4.56 \mathrm{E}-12\end{array}$ \\
\hline
\end{tabular}

\begin{tabular}{|l|cc|cc|cc|}
\hline \multicolumn{7}{|l|}{ Location: U-3at-D1 } \\
\hline Depth $(\mathrm{m})$ & $\begin{array}{c}20.5 \\
\theta\left(\mathrm{m}^{3} \mathrm{~m}^{-3}\right)\end{array}$ & $\mathrm{K}(\mathrm{m} / \mathrm{s})$ & $\begin{array}{c}22.9 \\
\theta\left(\mathrm{m}^{3} \mathrm{~m}^{-3}\right)\end{array}$ & $\mathrm{K}(\mathrm{m} / \mathrm{s})$ & $\begin{array}{c}25.4 \\
\theta\left(\mathrm{m}^{3} \mathrm{~m}^{-3}\right)\end{array}$ & $\mathrm{K}(\mathrm{m} / \mathrm{s})$ \\
\hline & 0.470 & $1.68 \mathrm{E}-05$ & 0.363 & $3.55 \mathrm{E}-06$ & 0.462 & $1.97 \mathrm{E}-06$ \\
& 0.418 & $1.58 \mathrm{E}-06$ & 0.333 & $1.58 \mathrm{E}-06$ & 0.450 & $5.28 \mathrm{E}-07$ \\
& 0.391 & $3.96 \mathrm{E}-07$ & 0.327 & $9.92 \mathrm{E}-07$ & 0.406 & $3.96 \mathrm{E}-07$ \\
& 0.333 & $1.43 \mathrm{E}-07$ & 0.273 & $1.43 \mathrm{E}-07$ & 0.377 & $1.43 \mathrm{E}-07$ \\
& 0.314 & $6.33 \mathrm{E}-08$ & 0.252 & $6.33 \mathrm{E}-08$ & 0.335 & $6.33 \mathrm{E}-08$ \\
& 0.300 & $2.85 \mathrm{E}-08$ & 0.234 & $2.85 \mathrm{E}-08$ & 0.306 & $2.85 \mathrm{E}-08$ \\
& 0.290 & $1.07 \mathrm{E}-08$ & 0.220 & $1.07 \mathrm{E}-08$ & 0.284 & $1.07 \mathrm{E}-08$ \\
& 0.282 & $3.56 \mathrm{E}-09$ & 0.211 & $3.56 \mathrm{E}-09$ & 0.270 & $3.56 \mathrm{E}-09$ \\
& 0.269 & $7.13 \mathrm{E}-10$ & 0.197 & $7.13 \mathrm{E}-10$ & 0.247 & $7.13 \mathrm{E}-10$ \\
& 0.259 & $2.69 \mathrm{E}-10$ & 0.185 & $2.69 \mathrm{E}-10$ & 0.232 & $2.69 \mathrm{E}-10$ \\
& 0.247 & $4.56 \mathrm{E}-11$ & 0.171 & $4.56 \mathrm{E}-11$ & 0.216 & $4.56 \mathrm{E}-11$ \\
& 0.237 & $2.50 \mathrm{E}-12$ & 0.161 & $2.50 \mathrm{E}-12$ & 0.200 & $2.50 \mathrm{E}-12$ \\
& & & & & & \\
\hline
\end{tabular}


Table B-5

Hydraulic Conductivity I Water Content Relations for U-3at-D1 Characterization Samples (continued)

(Depth in meters; volumetric water content $[\theta]$ in cubic meters per cubic meter; hydraulic conductivity $[\mathrm{K}]$ in meters per second)

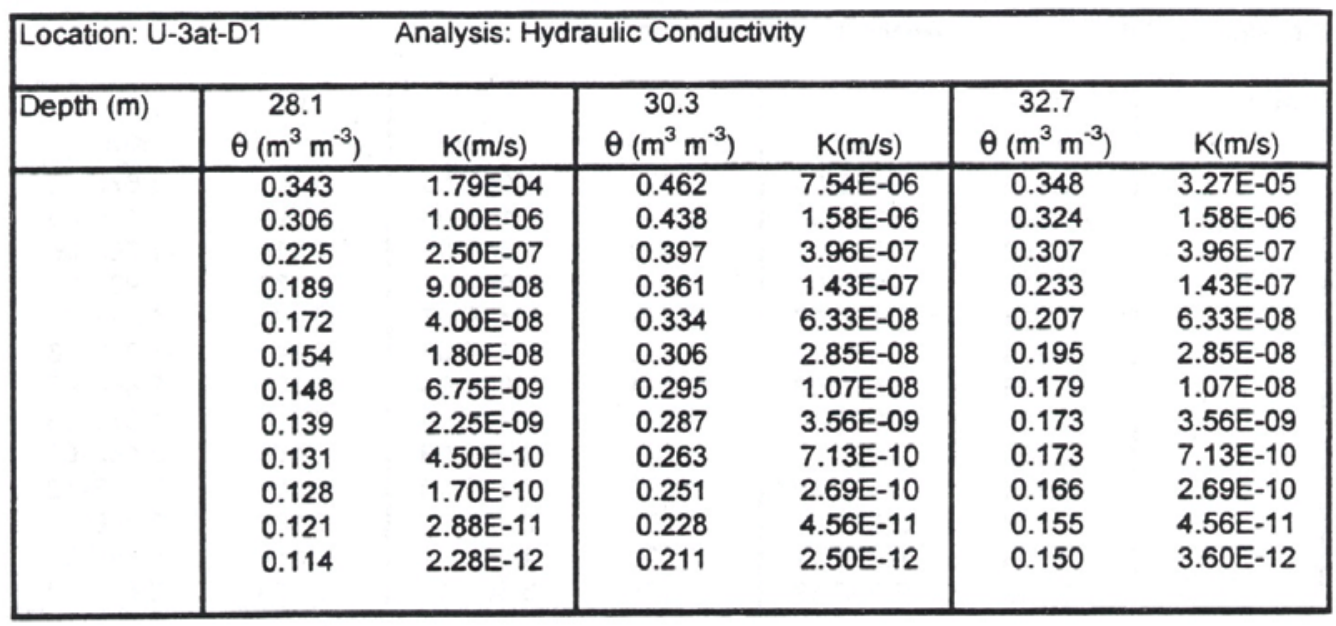

\begin{tabular}{|c|c|c|c|c|c|c|}
\hline \multicolumn{2}{|c|}{ Location: U-3at-D1 } & \multicolumn{4}{|c|}{ Analysis: Hydraulic Conductivity } & \\
\hline Depth (m) & $\begin{array}{c}35.4 \\
\theta\left(\mathrm{m}^{3} \mathrm{~m}^{-3}\right) \\
\end{array}$ & $\mathrm{K}(\mathrm{m} / \mathrm{s})$ & $\begin{array}{c}40.3 \\
\theta\left(\mathrm{m}^{3} \mathrm{~m}^{-3}\right)\end{array}$ & $\mathrm{K}(\mathrm{m} / \mathrm{s})$ & $\begin{array}{c}42.9 \\
\theta\left(\mathrm{m}^{3} \mathrm{~m}^{-3}\right)\end{array}$ & $\mathrm{K}(\mathrm{m} / \mathrm{s})$ \\
\hline & $\begin{array}{l}0.361 \\
0.327 \\
0.283 \\
0.210 \\
0.190 \\
0.183 \\
0.174 \\
0.168 \\
0.156 \\
0.150 \\
0.136 \\
0.126\end{array}$ & $\begin{array}{l}8.05 E-06 \\
1.58 E-06 \\
3.96 E-07 \\
1.43 E-07 \\
6.33 E-08 \\
2.85 E-08 \\
1.07 E-08 \\
3.56 E-09 \\
7.13 E-10 \\
2.69 E-10 \\
4.56 E-11 \\
3.60 E-12\end{array}$ & $\begin{array}{l}0.333 \\
0.163 \\
0.144 \\
0.139 \\
0.131 \\
0.122 \\
0.118 \\
0.110 \\
0.103\end{array}$ & $\begin{array}{l}3.66 \mathrm{E}-05 \\
9.00 \mathrm{E}-08 \\
1.80 \mathrm{E}-08 \\
6.75 \mathrm{E}-09 \\
2.25 \mathrm{E}-09 \\
4.50 \mathrm{E}-10 \\
1.70 \mathrm{E}-10 \\
2.88 \mathrm{E}-11 \\
2.28 \mathrm{E}-12\end{array}$ & $\begin{array}{l}0.386 \\
0.357 \\
0.334 \\
0.304 \\
0.282 \\
0.276 \\
0.266 \\
0.255 \\
0.236 \\
0.223 \\
0.213 \\
0.208\end{array}$ & $\begin{array}{l}1.09 \mathrm{E}-06 \\
1.00 \mathrm{E}-06 \\
2.50 \mathrm{E}-07 \\
9.00 \mathrm{E}-08 \\
4.00 \mathrm{E}-08 \\
1.80 \mathrm{E}-08 \\
6.75 \mathrm{E}-09 \\
2.25 \mathrm{E}-09 \\
4.50 \mathrm{E}-10 \\
1.70 \mathrm{E}-10 \\
2.88 \mathrm{E}-11 \\
2.28 \mathrm{E}-12\end{array}$ \\
\hline
\end{tabular}

Location: U-3at-D1
\begin{tabular}{|l|cc|cc|cc|}
\hline Depth (m) & 43.0 & & 46.8 & & 49.3 & \\
& $\theta\left(\mathrm{m}^{3} \mathrm{~m}^{-3}\right)$ & $\mathrm{K}(\mathrm{m} / \mathrm{s})$ & $\theta\left(\mathrm{m}^{3} \mathrm{~m}^{-3}\right)$ & $\mathrm{K}(\mathrm{m} / \mathrm{s})$ & $\theta\left(\mathrm{m}^{3} \mathrm{~m}^{-3}\right)$ & $\mathrm{K}(\mathrm{m} / \mathrm{s})$ \\
\hline & 0.292 & $1.10 \mathrm{E}-05$ & 0.341 & $2.15 \mathrm{E}-05$ & 0.415 & $7.43 \mathrm{E}-06$ \\
& 0.167 & $9.00 \mathrm{E}-08$ & 0.305 & $1.58 \mathrm{E}-06$ & 0.365 & $1.58 \mathrm{E}-06$ \\
& 0.148 & $4.00 \mathrm{E}-08$ & 0.268 & $3.96 \mathrm{E}-07$ & 0.354 & $3.96 \mathrm{E}-07$ \\
& 0.136 & $6.75 \mathrm{E}-09$ & 0.244 & $1.43 \mathrm{E}-07$ & 0.294 & $1.43 \mathrm{E}-07$ \\
& 0.130 & $2.25 \mathrm{E}-09$ & 0.228 & $6.33 \mathrm{E}-08$ & 0.272 & $6.33 \mathrm{E}-08$ \\
& 0.123 & $4.50 \mathrm{E}-10$ & 0.206 & $2.85 \mathrm{E}-08$ & 0.255 & $2.85 \mathrm{E}-08$ \\
& 0.118 & $1.70 \mathrm{E}-10$ & 0.203 & $1.07 \mathrm{E}-08$ & 0.243 & $1.07 \mathrm{E}-08$ \\
& 0.110 & $2.88 \mathrm{E}-11$ & 0.201 & $3.56 \mathrm{E}-09$ & 0.229 & $3.56 \mathrm{E}-09$ \\
& 0.104 & $2.28 \mathrm{E}-12$ & 0.190 & $7.13 \mathrm{E}-10$ & 0.214 & $7.13 \mathrm{E}-10$ \\
& & & 0.183 & $2.69 \mathrm{E}-10$ & 0.203 & $2.69 \mathrm{E}-10$ \\
& & 0.169 & $4.56 \mathrm{E}-11$ & 0.186 & $4.56 \mathrm{E}-11$ \\
& & & 0.158 & $2.50 \mathrm{E}-12$ & 0.170 & $3.60 \mathrm{E}-12$ \\
& & & & & & \\
\hline
\end{tabular}


Table B-5

Hydraulic Conductivity I Water Content Relations for U-3at-D1 Characterization Samples (continued)

(Depth in meters; volumetric water content $[\theta]$ in cubic meters per cubic meter; hydraulic conductivity $[\mathrm{K}]$ in meters per second)

\begin{tabular}{|c|c|c|c|c|c|c|}
\hline \multicolumn{2}{|c|}{ Location: U-3at-D1 } & \multicolumn{5}{|c|}{ Analysis: Hydraulic Conductivity } \\
\hline Depth (m) & $\begin{array}{c}52.0 \\
\theta\left(\mathrm{m}^{3} \mathrm{~m}^{-3}\right)\end{array}$ & $\mathrm{K}(\mathrm{m} / \mathrm{s})$ & $\begin{array}{c}54.4 \\
\theta\left(\mathrm{m}^{3} \mathrm{~m}^{-3}\right)\end{array}$ & $\mathrm{K}(\mathrm{m} / \mathrm{s})$ & $\begin{array}{c}56.8 \\
\theta\left(\mathrm{m}^{3} \mathrm{~m}^{-3}\right)\end{array}$ & $\mathrm{K}(\mathrm{m} / \mathrm{s})$ \\
\hline & $\begin{array}{l}0.446 \\
0.402 \\
0.387 \\
0.357 \\
0.344 \\
0.329 \\
0.311 \\
0.283 \\
0.262 \\
0.248 \\
0.229\end{array}$ & $\begin{array}{l}3.96 \mathrm{E}-07 \\
3.64 \mathrm{E}-07 \\
1.43 \mathrm{E}-07 \\
6.33 \mathrm{E}-08 \\
2.85 \mathrm{E}-08 \\
1.07 \mathrm{E}-08 \\
3.56 \mathrm{E}-09 \\
7.13 \mathrm{E}-10 \\
2.69 \mathrm{E}-10 \\
4.56 \mathrm{E}-11 \\
2.50 \mathrm{E}-12\end{array}$ & $\begin{array}{l}0.454 \\
0.408 \\
0.379 \\
0.353 \\
0.274 \\
0.221 \\
0.213 \\
0.204 \\
0.196 \\
0.192 \\
0.174 \\
0.159 \\
0.149\end{array}$ & $\begin{array}{l}1.76 \mathrm{E}-05 \\
9.40 \mathrm{E}-06 \\
1.58 \mathrm{E}-06 \\
3.96 \mathrm{E}-07 \\
1.43 \mathrm{E}-07 \\
6.33 \mathrm{E}-08 \\
2.85 \mathrm{E}-08 \\
1.07 \mathrm{E}-08 \\
3.56 \mathrm{E}-09 \\
7.13 \mathrm{E}-10 \\
2.69 \mathrm{E}-10 \\
4.56 \mathrm{E}-11 \\
4.56 \mathrm{E}-12\end{array}$ & $\begin{array}{l}0.340 \\
0.333 \\
0.281 \\
0.237 \\
0.223 \\
0.201 \\
0.194 \\
0.188 \\
0.169 \\
0.168 \\
0.150 \\
0.147\end{array}$ & $\begin{array}{l}4.40 \mathrm{E}-05 \\
1.00 \mathrm{E}-06 \\
2.50 \mathrm{E}-07 \\
9.00 \mathrm{E}-08 \\
4.00 \mathrm{E}-08 \\
1.80 \mathrm{E}-08 \\
6.75 \mathrm{E}-09 \\
2.25 \mathrm{E}-09 \\
4.50 \mathrm{E}-10 \\
1.70 \mathrm{E}-10 \\
2.88 \mathrm{E}-11 \\
2.28 \mathrm{E}-12\end{array}$ \\
\hline
\end{tabular}

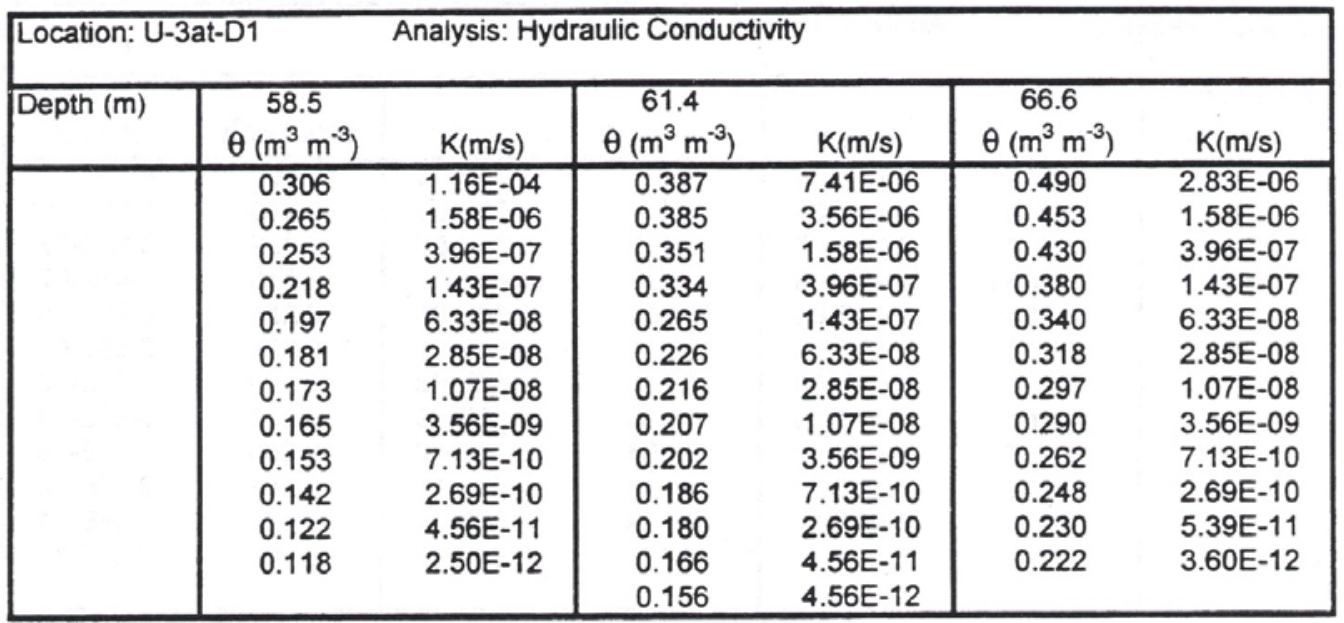

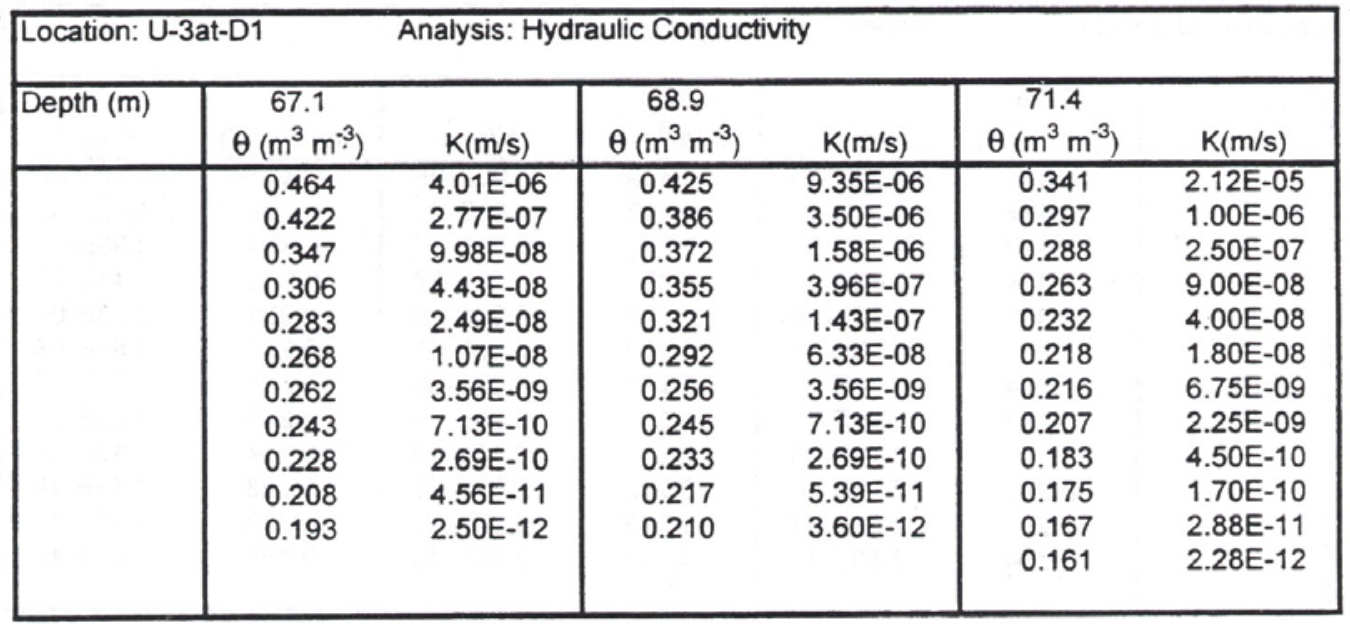


Table B-5

Hydraulic Conductivity I Water Content Relations for U-3at-D1 Characterization Samples (continued)

(Depth in meters; volumetric water content $[\theta]$ in cubic meters per cubic meter; hydraulic conductivity $[\mathrm{K}]$ in meters per second)

\begin{tabular}{|c|c|c|c|c|c|c|}
\hline \multicolumn{2}{|c|}{ Location: U-3at-D1 } & \multicolumn{5}{|c|}{ Analysis: Hydraulic Conductivity } \\
\hline Depth (m) & $\begin{array}{c}74.0 \\
\theta\left(\mathrm{m}^{3} \mathrm{~m}^{-3}\right)\end{array}$ & $\mathrm{K}(\mathrm{m} / \mathrm{s})$ & $\begin{array}{c}76.3 \\
\theta\left(\mathrm{m}^{3} \mathrm{~m}^{-3}\right)\end{array}$ & $\mathrm{K}(\mathrm{m} / \mathrm{s})$ & $\begin{array}{c}78.8 \\
\theta\left(\mathrm{m}^{3} \mathrm{~m}^{-3}\right)\end{array}$ & $\mathrm{K}(\mathrm{m} / \mathrm{s})$ \\
\hline & $\begin{array}{l}0.344 \\
0.312 \\
0.292 \\
0.258 \\
0.230 \\
0.213 \\
0.196 \\
0.192 \\
0.174 \\
0.167 \\
0.155 \\
0.143\end{array}$ & $\begin{array}{l}3.69 \mathrm{E}-06 \\
1.58 \mathrm{E}-06 \\
3.96 \mathrm{E}-07 \\
1.43 \mathrm{E}-07 \\
6.33 \mathrm{E}-08 \\
2.85 \mathrm{E}-08 \\
1.07 \mathrm{E}-08 \\
3.56 \mathrm{E}-09 \\
7.13 \mathrm{E}-10 \\
2.69 \mathrm{E}-10 \\
4.56 \mathrm{E}-11 \\
2.50 \mathrm{E}-12\end{array}$ & $\begin{array}{l}0.408 \\
0.378 \\
0.365 \\
0.335 \\
0.298 \\
0.281 \\
0.263 \\
0.257 \\
0.231 \\
0.219 \\
0.196 \\
0.188\end{array}$ & $\begin{array}{l}2.77 \mathrm{E}-05 \\
1.12 \mathrm{E}-05 \\
1.58 \mathrm{E}-06 \\
3.96 \mathrm{E}-07 \\
1.43 \mathrm{E}-07 \\
6.33 \mathrm{E}-08 \\
2.85 \mathrm{E}-08 \\
1.07 \mathrm{E}-08 \\
7.13 \mathrm{E}-10 \\
2.69 \mathrm{E}-10 \\
4.56 \mathrm{E}-11 \\
2.50 \mathrm{E}-12\end{array}$ & $\begin{array}{l}0.434 \\
0.411 \\
0.383 \\
0.369 \\
0.328 \\
0.284 \\
0.272 \\
0.252 \\
0.236 \\
0.219 \\
0.199 \\
0.186 \\
0.182\end{array}$ & $\begin{array}{l}3.89 E-05 \\
1.82 E-06 \\
1.58 E-06 \\
3.96 E-07 \\
1.43 E-07 \\
6.33 E-08 \\
2.85 E-08 \\
1.07 E-08 \\
3.56 E-09 \\
7.13 E-10 \\
2.69 E-10 \\
5.39 E-11 \\
6.84 E-12\end{array}$ \\
\hline
\end{tabular}

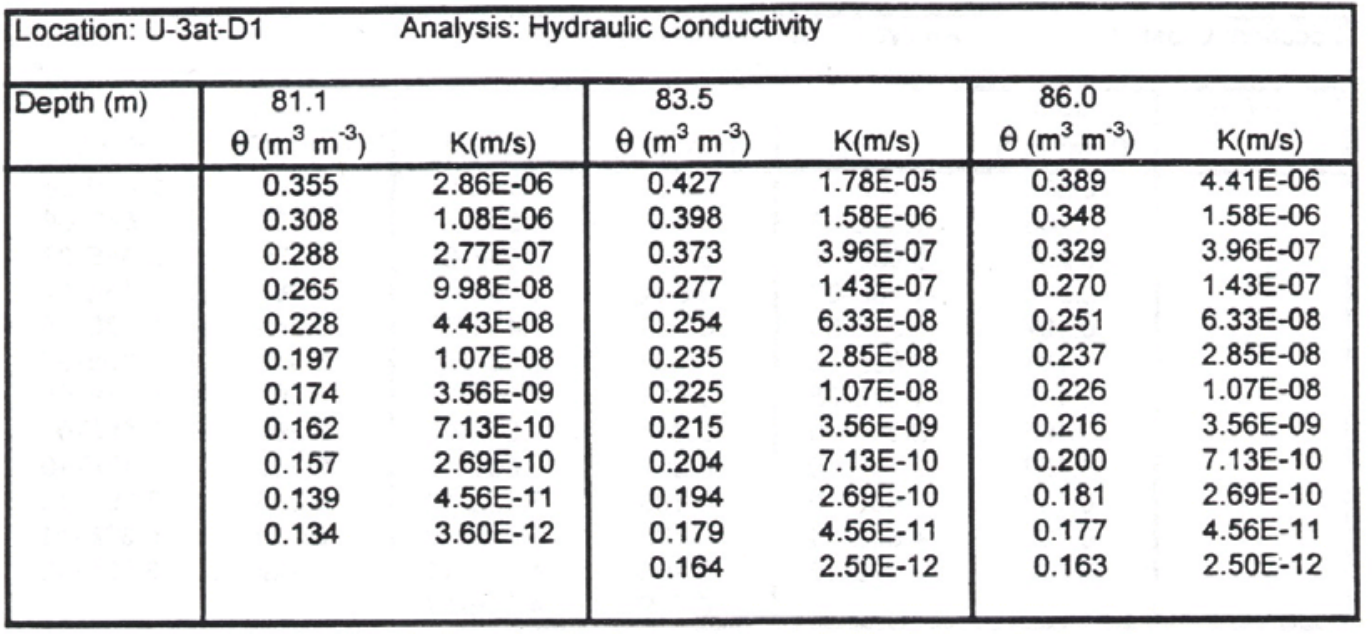

\begin{tabular}{|c|c|c|c|c|c|c|}
\hline \multicolumn{2}{|c|}{ Location: U-3at-D1 } & \multicolumn{4}{|c|}{ Analysis: Hydraulic Conductivity } & \\
\hline Depth (m) & $\begin{array}{c}88.4 \\
\theta\left(\mathrm{m}^{3} \mathrm{~m}^{-3}\right)\end{array}$ & $\mathrm{K}(\mathrm{m} / \mathrm{s})$ & $\begin{array}{c}90.7 \\
\theta\left(\mathrm{m}^{3} \mathrm{~m}^{-3}\right)\end{array}$ & $\mathrm{K}(\mathrm{m} / \mathrm{s})$ & $\begin{array}{c}93.3 \\
\theta\left(\mathrm{m}^{3} \mathrm{~m}^{-3}\right) \\
\end{array}$ & $\mathrm{K}(\mathrm{m} / \mathrm{s})$ \\
\hline & $\begin{array}{l}0.479 \\
0.434 \\
0.377 \\
0.334 \\
0.307 \\
0.285 \\
0.274 \\
0.261 \\
0.240 \\
0.228 \\
0.211 \\
0.194\end{array}$ & $\begin{array}{l}3.02 E-06 \\
1.58 E-06 \\
3.96 E-07 \\
1.43 E-07 \\
6.33 E-08 \\
2.85 E-08 \\
1.07 E-08 \\
3.56 E-09 \\
7.13 E-10 \\
2.69 E-10 \\
4.56 E-11 \\
2.50 E-12\end{array}$ & $\begin{array}{l}0.459 \\
0.403 \\
0.376 \\
0.301 \\
0.277 \\
0.258 \\
0.247 \\
0.231 \\
0.217 \\
0.205 \\
0.188 \\
0.181\end{array}$ & $\begin{array}{l}1.60 E-05 \\
1.58 E-06 \\
3.96 E-07 \\
1.43 E-07 \\
6.33 E-08 \\
2.85 E-08 \\
1.07 E-08 \\
3.56 E-09 \\
7.13 E-10 \\
2.69 E-10 \\
4.56 E-11 \\
3.60 E-12\end{array}$ & $\begin{array}{l}0.411 \\
0.396 \\
0.364 \\
0.333 \\
0.301 \\
0.278 \\
0.275 \\
0.266 \\
0.234 \\
0.223 \\
0.203 \\
0.199\end{array}$ & $\begin{array}{l}5.44 \mathrm{E}-06 \\
4.02 \mathrm{E}-07 \\
3.96 \mathrm{E}-07 \\
1.43 \mathrm{E}-07 \\
6.33 \mathrm{E}-08 \\
2.85 \mathrm{E}-08 \\
1.07 \mathrm{E}-08 \\
3.56 \mathrm{E}-09 \\
7.13 \mathrm{E}-10 \\
2.69 \mathrm{E}-10 \\
4.60 \mathrm{E}-11 \\
3.81 \mathrm{E}-12\end{array}$ \\
\hline
\end{tabular}


Table B-5

Hydraulic Conductivity I Water Content Relations for U-3at-D1 Characterization Samples (continued)

(Depth in meters; volumetric water content $[\theta]$ in cubic meters per cubic meter; hydraulic conductivity $[\mathrm{K}]$ in meters per second)

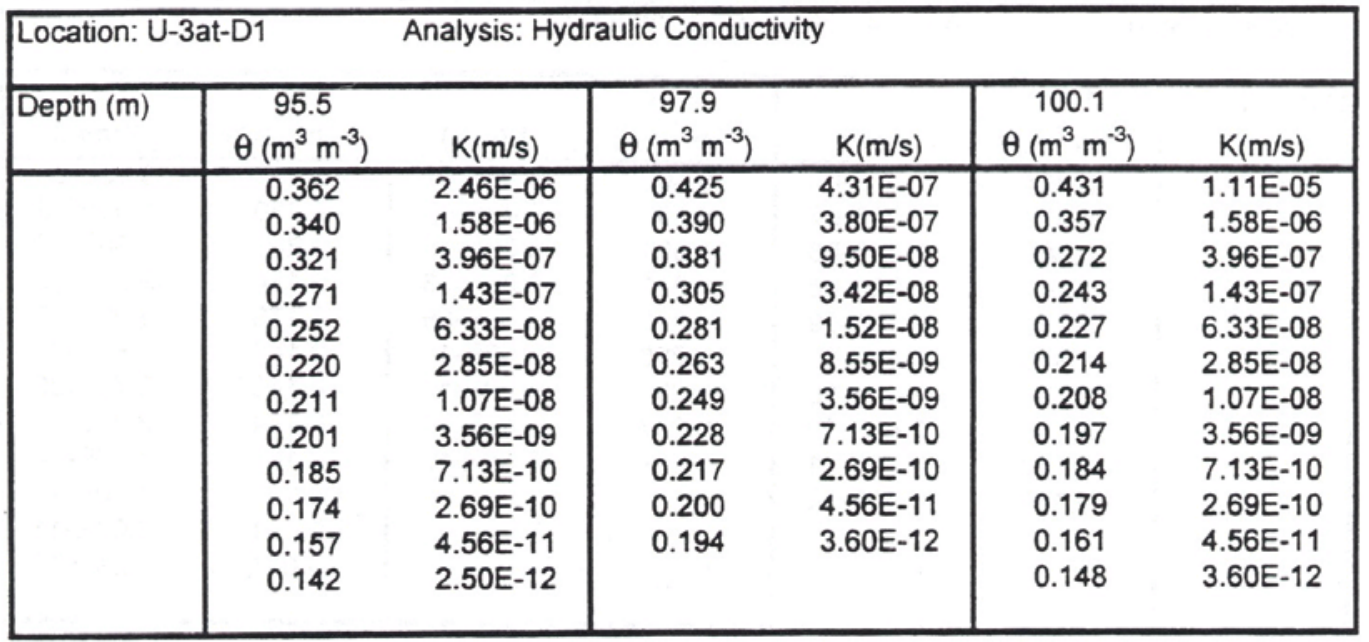

\begin{tabular}{|c|c|c|c|c|c|c|}
\hline \multicolumn{2}{|c|}{ Location: U-3at-D1 } & \multicolumn{4}{|c|}{ Analysis: Hydraulic Conductivity } & \\
\hline Depth $(m)$ & $\begin{array}{c}105.1 \\
\theta\left(\mathrm{m}^{3} \mathrm{~m}^{-3}\right)\end{array}$ & $\mathrm{K}(\mathrm{m} / \mathrm{s})$ & $\begin{array}{c}107.4 \\
\theta\left(\mathrm{m}^{3} \mathrm{~m}^{-3}\right)\end{array}$ & $\mathrm{K}(\mathrm{m} / \mathrm{s})$ & $\begin{array}{c}109.8 \\
\theta\left(\mathrm{m}^{3} \mathrm{~m}^{-3}\right)\end{array}$ & $\mathrm{K}(\mathrm{m} / \mathrm{s})$ \\
\hline & $\begin{array}{l}0.430 \\
0.402 \\
0.363 \\
0.332 \\
0.318 \\
0.299 \\
0.284 \\
0.270\end{array}$ & $\begin{array}{l}8.44 E-08 \\
1.98 E-08 \\
7.13 E-09 \\
3.17 E-09 \\
7.13 E-10 \\
2.69 E-10 \\
4.56 E-11 \\
2.50 E-12\end{array}$ & $\begin{array}{l}0.439 \\
0.385 \\
0.334 \\
0.299 \\
0.269 \\
0.257 \\
0.243 \\
0.217 \\
0.201 \\
0.184 \\
0.164\end{array}$ & $\begin{array}{l}2.56 \mathrm{E}-06 \\
3.96 \mathrm{E}-07 \\
1.43 \mathrm{E}-07 \\
6.33 \mathrm{E}-08 \\
2.85 \mathrm{E}-08 \\
1.07 \mathrm{E}-08 \\
3.56 \mathrm{E}-09 \\
7.13 \mathrm{E}-10 \\
2.69 \mathrm{E}-10 \\
4.56 \mathrm{E}-11 \\
2.50 \mathrm{E}-12\end{array}$ & $\begin{array}{l}0.481 \\
0.503 \\
0.453 \\
0.436 \\
0.408 \\
0.383 \\
0.350 \\
0.332 \\
0.307 \\
0.287 \\
0.269 \\
0.249\end{array}$ & $\begin{array}{l}7.21 \mathrm{E}-07 \\
7.55 \mathrm{E}-07 \\
3.96 \mathrm{E}-07 \\
1.43 \mathrm{E}-07 \\
6.33 \mathrm{E}-08 \\
2.85 \mathrm{E}-08 \\
1.07 \mathrm{E}-08 \\
3.56 \mathrm{E}-09 \\
7.13 \mathrm{E}-10 \\
2.69 \mathrm{E}-10 \\
4.56 \mathrm{E}-11 \\
2.50 \mathrm{E}-12\end{array}$ \\
\hline
\end{tabular}

\begin{tabular}{|c|c|c|c|c|c|c|}
\hline \multicolumn{2}{|c|}{ Location: U-3at-D1 } & \multicolumn{4}{|c|}{ Analysis: Hydraulic Conductivity } & \\
\hline Depth $(m)$ & $\begin{array}{c}112.3 \\
\theta\left(\mathrm{m}^{3} \mathrm{~m}^{-3}\right) \\
\end{array}$ & $\mathrm{K}(\mathrm{m} / \mathrm{s})$ & $\begin{array}{c}114.6 \\
\theta\left(\mathrm{m}^{3} \mathrm{~m}^{-3}\right) \\
\end{array}$ & $\mathrm{K}(\mathrm{m} / \mathrm{s})$ & $\begin{array}{c}117.0 \\
\theta\left(\mathrm{m}^{3} \mathrm{~m}^{-3}\right)\end{array}$ & $\mathrm{K}(\mathrm{m} / \mathrm{s})$ \\
\hline & $\begin{array}{l}0.380 \\
0.354 \\
0.338 \\
0.304 \\
0.282 \\
0.264 \\
0.249 \\
0.226 \\
0.215 \\
0.199 \\
0.182 \\
0.168\end{array}$ & $\begin{array}{l}1.16 \mathrm{E}-06 \\
9.23 \mathrm{E}-07 \\
2.38 \mathrm{E}-07 \\
8.55 \mathrm{E}-08 \\
3.80 \mathrm{E}-08 \\
2.14 \mathrm{E}-08 \\
1.07 \mathrm{E}-08 \\
3.56 \mathrm{E}-09 \\
7.13 \mathrm{E}-10 \\
2.69 \mathrm{E}-10 \\
4.56 \mathrm{E}-11 \\
2.50 \mathrm{E}-12\end{array}$ & $\begin{array}{l}0.398 \\
0.380 \\
0.373 \\
0.341 \\
0.317 \\
0.305 \\
0.290 \\
0.258 \\
0.242 \\
0.218 \\
0.214\end{array}$ & $\begin{array}{l}2.89 \mathrm{E}-06 \\
3.80 \mathrm{E}-07 \\
9.50 \mathrm{E}-08 \\
3.42 \mathrm{E}-08 \\
1.52 \mathrm{E}-08 \\
8.55 \mathrm{E}-09 \\
3.56 \mathrm{E}-09 \\
7.13 \mathrm{E}-10 \\
2.69 \mathrm{E}-10 \\
4.56 \mathrm{E}-11 \\
3.60 \mathrm{E}-12\end{array}$ & $\begin{array}{l}0.318 \\
0.288 \\
0.280 \\
0.234 \\
0.213 \\
0.202 \\
0.190 \\
0.179 \\
0.171 \\
0.163 \\
0.150 \\
0.135\end{array}$ & $\begin{array}{l}1.02 \mathrm{E}-06 \\
9.50 \mathrm{E}-07 \\
2.38 \mathrm{E}-07 \\
8.55 \mathrm{E}-08 \\
3.80 \mathrm{E}-08 \\
2.14 \mathrm{E}-08 \\
1.07 \mathrm{E}-08 \\
3.56 \mathrm{E}-09 \\
7.13 \mathrm{E}-10 \\
2.69 \mathrm{E}-10 \\
4.56 \mathrm{E}-11 \\
2.50 \mathrm{E}-12\end{array}$ \\
\hline
\end{tabular}


Table B-5

Hydraulic Conductivity I Water Content Relations for U-3at-D1 Characterization Samples (continued)

(Depth in meters; volumetric water content $[\theta]$ in cubic meters per cubic meter; hydraulic conductivity $[\mathrm{K}]$ in meters per second)

\begin{tabular}{|c|c|c|c|c|c|c|}
\hline \multicolumn{2}{|c|}{ Location: U-3at-D1 } & \multicolumn{5}{|c|}{ Analysis: Hydraulic Conductivity } \\
\hline Depth (m) & $\begin{array}{c}119.3 \\
\theta\left(\mathrm{m}^{3} \mathrm{~m}^{-3}\right)\end{array}$ & $K(\mathrm{~m} / \mathrm{s})$ & $\begin{array}{c}121.8 \\
\theta\left(\mathrm{m}^{3} \mathrm{~m}^{-3}\right)\end{array}$ & $\mathrm{K}(\mathrm{m} / \mathrm{s})$ & $\begin{array}{c}124.2 \\
\theta\left(m^{3} m^{-3}\right)\end{array}$ & $\mathrm{K}(\mathrm{m} / \mathrm{s})$ \\
\hline & $\begin{array}{l}0.384 \\
0.379 \\
0.369 \\
0.365 \\
0.348 \\
0.319 \\
0.279 \\
0.265 \\
0.247 \\
0.229\end{array}$ & $\begin{array}{l}1.77 E-06 \\
2.02 E-07 \\
7.92 E-08 \\
1.98 E-08 \\
7.13 E-09 \\
3.17 E-09 \\
7.13 E-10 \\
2.69 E-10 \\
4.56 E-11 \\
2.50 E-12\end{array}$ & $\begin{array}{l}0.403 \\
0.393 \\
0.361 \\
0.341 \\
0.315 \\
0.298 \\
0.291 \\
0.267 \\
0.249\end{array}$ & $\begin{array}{l}3.96 E-07 \\
1.43 E-07 \\
6.33 E-08 \\
2.85 E-08 \\
3.56 E-09 \\
7.13 E-10 \\
2.69 E-10 \\
4.56 E-11 \\
2.50 E-12\end{array}$ & $\begin{array}{l}0.347 \\
0.230 \\
0.205 \\
0.184 \\
0.173 \\
0.149 \\
0.146 \\
0.134 \\
0.107 \\
0.102 \\
0.091 \\
0.087\end{array}$ & $\begin{array}{l}3.62 \mathrm{E}-06 \\
1.00 \mathrm{E}-06 \\
2.50 \mathrm{E}-07 \\
9.00 \mathrm{E}-08 \\
4.00 \mathrm{E}-08 \\
1.80 \mathrm{E}-08 \\
6.75 \mathrm{E}-09 \\
2.25 \mathrm{E}-09 \\
4.50 \mathrm{E}-10 \\
1.70 \mathrm{E}-10 \\
3.00 \mathrm{E}-11 \\
2.29 \mathrm{E}-12\end{array}$ \\
\hline
\end{tabular}

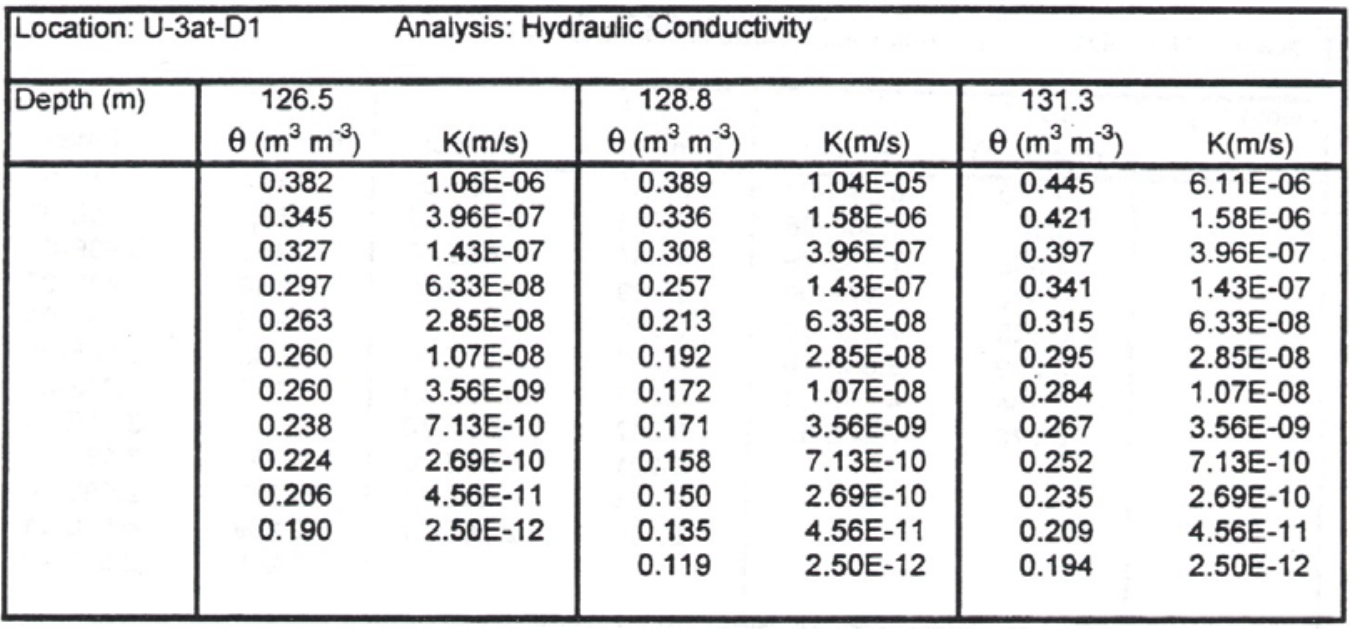

\begin{tabular}{|l|cc|cc|cc|}
\hline \multicolumn{7}{|l|}{ Location: U-3at-D1 } \\
\hline Depth $(\mathrm{m})$ & $\begin{array}{c}133.5 \\
\theta\left(\mathrm{m}^{3} \mathrm{~m}^{-3}\right)\end{array}$ & $\mathrm{K}(\mathrm{m} / \mathrm{s})$ & $\begin{array}{c}136.1 \\
\left(\mathrm{~m}^{3} \mathrm{~m}^{-3}\right)\end{array}$ & $\mathrm{K}(\mathrm{m} / \mathrm{s})$ & $\theta\left(\mathrm{m}^{3} \mathrm{~m}^{-3}\right)$ & $\mathrm{K}(\mathrm{m} / \mathrm{s})$ \\
\hline & 0.424 & $1.71 \mathrm{E}-05$ & 0.325 & $1.04 \mathrm{E}-06$ & 0.396 & $1.11 \mathrm{E}-05$ \\
& 0.386 & $1.58 \mathrm{E}-06$ & 0.298 & $7.92 \mathrm{E}-08$ & 0.336 & $1.58 \mathrm{E}-06$ \\
& 0.346 & $3.96 \mathrm{E}-07$ & 0.291 & $2.85 \mathrm{E}-08$ & 0.275 & $3.96 \mathrm{E}-07$ \\
& 0.277 & $1.43 \mathrm{E}-07$ & 0.280 & $1.27 \mathrm{E}-08$ & 0.241 & $1.43 \mathrm{E}-07$ \\
& 0.253 & $6.33 \mathrm{E}-08$ & 0.262 & $7.13 \mathrm{E}-09$ & 0.219 & $6.33 \mathrm{E}-08$ \\
& 0.236 & $2.85 \mathrm{E}-08$ & 0.239 & $3.56 \mathrm{E}-09$ & 0.203 & $2.85 \mathrm{E}-08$ \\
& 0.226 & $1.07 \mathrm{E}-08$ & 0.220 & $7.13 \mathrm{E}-10$ & 0.194 & $1.07 \mathrm{E}-08$ \\
& 0.218 & $3.56 \mathrm{E}-09$ & 0.214 & $2.69 \mathrm{E}-10$ & 0.185 & $3.56 \mathrm{E}-09$ \\
& 0.201 & $7.13 \mathrm{E}-10$ & 0.195 & $4.56 \mathrm{E}-11$ & 0.169 & $7.13 \mathrm{E}-10$ \\
& 0.183 & $2.69 \mathrm{E}-10$ & 0.182 & $2.50 \mathrm{E}-12$ & 0.157 & $2.69 \mathrm{E}-10$ \\
& 0.161 & $4.56 \mathrm{E}-11$ & & & 0.144 & $4.56 \mathrm{E}-11$ \\
& 0.146 & $2.50 \mathrm{E}-12$ & & & 0.130 & $2.50 \mathrm{E}-12$ \\
& & & & & & \\
\hline
\end{tabular}


Table B-5

Hydraulic Conductivity / Water Content Relations for U-3at-D1 Characterization Samples (continued)

(Depth in meters; volumetric water content $[\theta]$ in cubic meters per cubic meter; hydraulic conductivity $[\mathrm{K}]$ in meters per second)

\begin{tabular}{|c|c|c|c|c|c|c|}
\hline \multicolumn{7}{|c|}{ Analysis: Hydraulic Conductivity } \\
\hline Depth (m) & $\begin{array}{c}140.9 \\
\theta\left(\mathrm{m}^{3} \mathrm{~m}^{-3}\right)\end{array}$ & $\mathrm{K}(\mathrm{m} / \mathrm{s})$ & $\begin{array}{c}143.0 \\
\theta\left(\mathrm{m}^{3} \mathrm{~m}^{-3}\right)\end{array}$ & $\mathrm{K}(\mathrm{m} / \mathrm{s})$ & $\begin{array}{c}145.6 \\
\theta\left(\mathrm{m}^{3} \mathrm{~m}^{-3}\right)\end{array}$ & $\mathrm{K}(\mathrm{m} / \mathrm{s})$ \\
\hline & $\begin{array}{l}0.353 \\
0.349 \\
0.345 \\
0.302 \\
0.280 \\
0.264 \\
0.245 \\
0.233 \\
0.217 \\
0.203 \\
0.183 \\
0.168\end{array}$ & $\begin{array}{l}9.36 \mathrm{E}-06 \\
1.58 \mathrm{E}-06 \\
3.96 \mathrm{E}-07 \\
1.43 \mathrm{E}-07 \\
6.33 \mathrm{E}-08 \\
2.85 \mathrm{E}-08 \\
1.07 \mathrm{E}-08 \\
3.56 \mathrm{E}-09 \\
7.13 \mathrm{E}-10 \\
2.69 \mathrm{E}-10 \\
4.56 \mathrm{E}-11 \\
2.50 \mathrm{E}-12\end{array}$ & $\begin{array}{l}0.376 \\
0.402 \\
0.368 \\
0.334 \\
0.250 \\
0.225 \\
0.207 \\
0.197 \\
0.185 \\
0.167 \\
0.158 \\
0.140 \\
0.120\end{array}$ & $\begin{array}{l}1.25 \mathrm{E}-05 \\
2.25 \mathrm{E}-05 \\
1.58 \mathrm{E}-06 \\
3.96 \mathrm{E}-07 \\
1.43 \mathrm{E}-07 \\
6.33 \mathrm{E}-08 \\
2.85 \mathrm{E}-08 \\
1.07 \mathrm{E}-08 \\
3.56 \mathrm{E}-09 \\
7.13 \mathrm{E}-10 \\
2.69 \mathrm{E}-10 \\
4.56 \mathrm{E}-11 \\
2.50 \mathrm{E}-12\end{array}$ & $\begin{array}{l}0.433 \\
0.390 \\
0.377 \\
0.304 \\
0.284 \\
0.260 \\
0.249 \\
0.231 \\
0.209 \\
0.188 \\
0.170 \\
0.155\end{array}$ & $\begin{array}{l}4.89 \mathrm{E}-06 \\
1.58 \mathrm{E}-06 \\
3.96 \mathrm{E}-07 \\
1.43 \mathrm{E}-07 \\
6.33 \mathrm{E}-08 \\
2.85 \mathrm{E}-08 \\
1.07 \mathrm{E}-08 \\
3.56 \mathrm{E}-09 \\
7.13 \mathrm{E}-10 \\
2.69 \mathrm{E}-10 \\
4.56 \mathrm{E}-11 \\
2.50 \mathrm{E}-12\end{array}$ \\
\hline
\end{tabular}

\begin{tabular}{|l|cc|l|l|}
\hline \multicolumn{5}{|c|}{ Analysis: Hydraulic Conductivity } \\
\hline Depth (m) & 147.2 & $\mathrm{~K}(\mathrm{~m} / \mathrm{s})$ & & \\
& $\theta\left(\mathrm{m}^{3} \mathrm{~m}^{-3}\right)$ & & \\
& 0.311 & $9.00 \mathrm{E}-08$ & & \\
& 0.310 & $4.00 \mathrm{E}-08$ & & \\
& 0.288 & $1.80 \mathrm{E}-08$ & & \\
& 0.284 & $6.75 \mathrm{E}-09$ & & \\
& 0.272 & $2.25 \mathrm{E}-09$ & & \\
& 0.258 & $4.50 \mathrm{E}-10$ & & \\
& 0.253 & $1.70 \mathrm{E}-10$ & & \\
& 0.242 & $3.00 \mathrm{E}-11$ & & \\
& 0.232 & $2.29 \mathrm{E}-12$ & & \\
& & & & \\
& & & & \\
& & & & \\
\end{tabular}


Table B-6

Volumetric Water Content for U-3at-D1 Characterization Samples

(Depth in meters; water content in cubic meters per cubic meter)

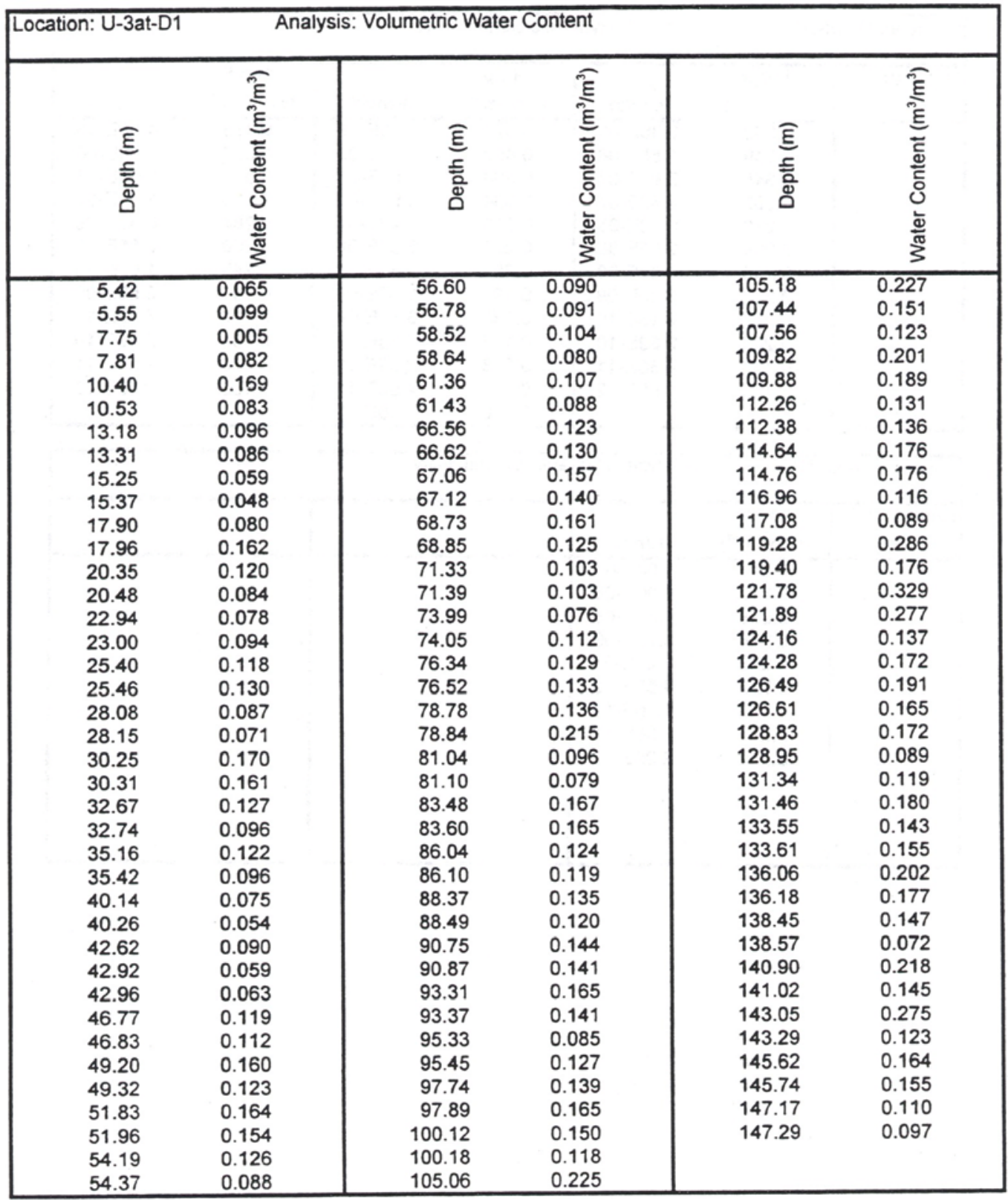


Table B-7

Water Potential for U-3at-D1 Characterization Samples

(Depth in meters; water potential in MegaPascals)

\begin{tabular}{|c|c|c|c|}
\hline Location: U-3at-D1 & Analysis: Wate & & \\
\hline $\begin{array}{l}\widehat{\text { Eิ }} \\
\text { 言 } \\
\text { D }\end{array}$ & 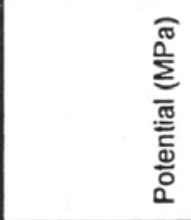 & 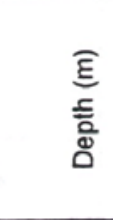 & 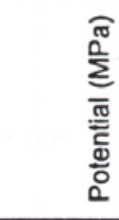 \\
\hline $\begin{array}{r}5.55 \\
7.75 \\
10.40 \\
13.18 \\
15.25 \\
17.96 \\
20.35 \\
23.00 \\
25.46 \\
28.08 \\
30.25 \\
32.67 \\
35.16 \\
40.14 \\
42.62 \\
46.77 \\
49.20 \\
51.83 \\
54.19 \\
56.60 \\
58.64 \\
61.43 \\
66.62 \\
67.06 \\
68.73 \\
71.33 \\
74.05 \\
76.52 \\
78.78 \\
\end{array}$ & $\begin{array}{r}-7.729 \\
-8.792 \\
-5.345 \\
-4.732 \\
-10.670 \\
-2.439 \\
-2.765 \\
-8.083 \\
-2.070 \\
-2.210 \\
-1.420 \\
-1.515 \\
-1.886 \\
-2.582 \\
-1.655 \\
-1.193 \\
-0.917 \\
-1.056 \\
-1.195 \\
-1.287 \\
-0.642 \\
-1.197 \\
-1.661 \\
-0.921 \\
-1.060 \\
-1.801 \\
-0.644 \\
-1.060 \\
>-0.400\end{array}$ & $\begin{array}{r}81.04 \\
83.48 \\
86.04 \\
88.37 \\
90.75 \\
93.31 \\
95.45 \\
97.89 \\
100.12 \\
105.06 \\
107.44 \\
109.82 \\
112.26 \\
114.64 \\
116.96 \\
119.28 \\
121.78 \\
124.16 \\
126.49 \\
128.83 \\
131.34 \\
133.55 \\
136.06 \\
138.45 \\
140.90 \\
143.05 \\
145.62 \\
147.17\end{array}$ & $\begin{array}{r}-2.645 \\
-1.147 \\
-0.824 \\
-0.963 \\
-0.917 \\
-0.780 \\
-0.733 \\
-0.733 \\
-0.458 \\
-0.596 \\
-0.504 \\
>-0.400 \\
-0.730 \\
-0.548 \\
-1.192 \\
>-0.400 \\
>-0.400 \\
>-0.400 \\
>-0.400 \\
>-0.400 \\
>-0.400 \\
>-0.400 \\
>-0.400 \\
>-0.400 \\
>-0.400 \\
>-0.400 \\
>-0.400 \\
>-0.400\end{array}$ \\
\hline
\end{tabular}


Table B-8

Stable Isotope Concentrations for U-3at-D1 Characterization Samples

(Depth in meters; oxygen-18 $\left[{ }^{18} \mathrm{O}\right]$ and deuterium [D] concentrations expressed in standard delta notation relative to standard mean ocean water in parts per thousand)

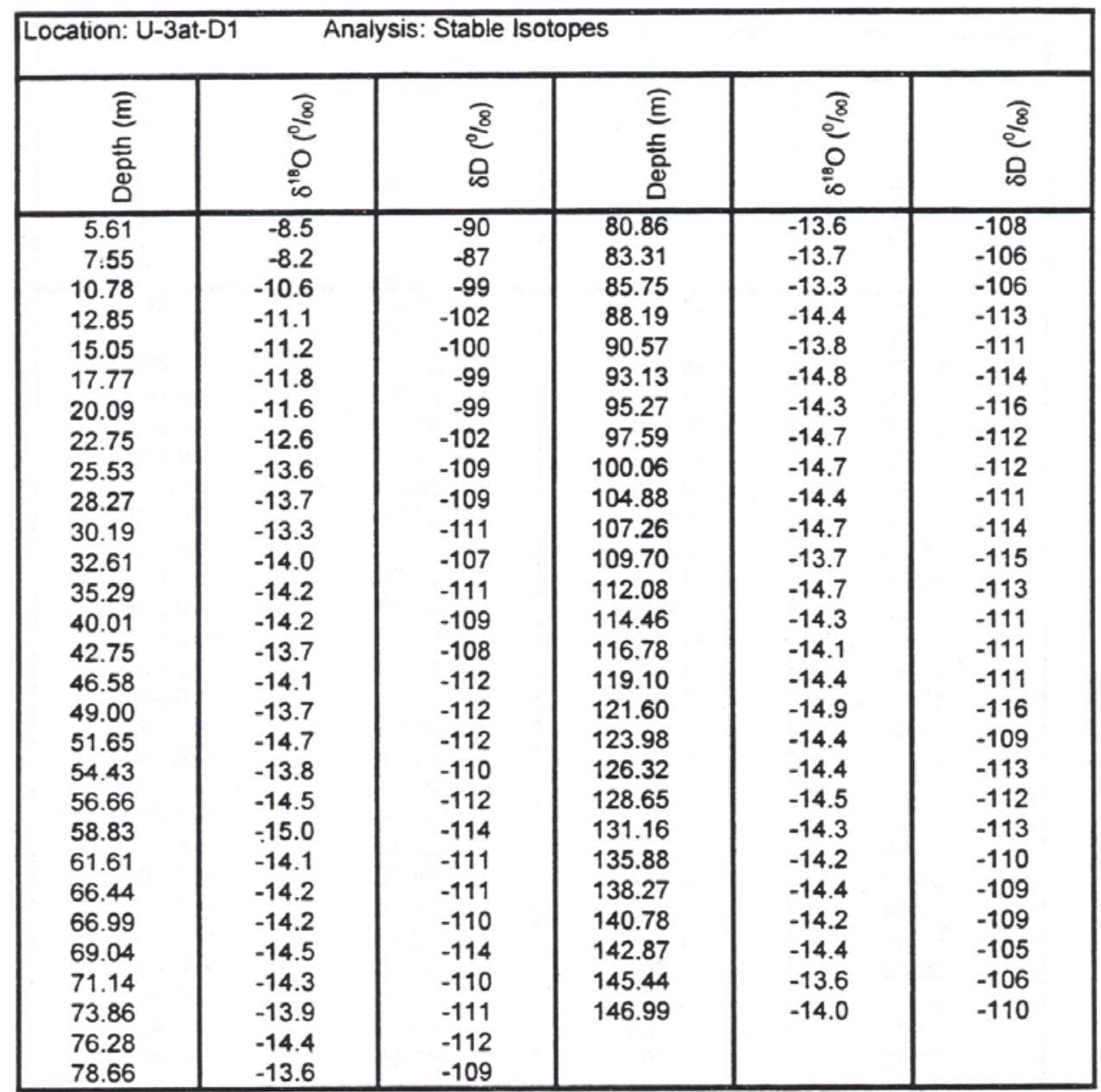


Table B-9

Soil Chloride Concentrations for U-3at-D1 Characterization Samples (Depth in meters; chloride in milligrams per kilogram)

\begin{tabular}{|c|c|c|c|}
\hline Location: U-3at-D1 & \multicolumn{2}{|c|}{ Analysis: Soil Chloride } & \multirow[b]{2}{*}{$\begin{array}{l}\text { के } \\
\text { 흠 } \\
\text { 은 } \\
\text { 흔 }\end{array}$} \\
\hline 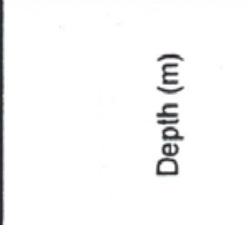 & $\begin{array}{l}\text { के } \\
\text { Dे } \\
\text { E } \\
\text { 흫 } \\
\text { 은 }\end{array}$ & 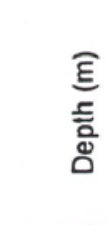 & \\
\hline 5.32 & 74.2 & 78.81 & 1.3 \\
\hline 7.65 & 27.5 & 81.10 & 3.3 \\
\hline 10.69 & 7.2 & 83.40 & 1.4 \\
\hline 13.05 & 3.4 & 85.84 & 1.3 \\
\hline 15.15 & 1.9 & 88.28 & 0.8 \\
\hline 17.93 & 3.9 & 90.66 & 0.7 \\
\hline 20.42 & 3.6 & 93.22 & 0.7 \\
\hline 22.94 & 2.0 & 95.48 & 0.6 \\
\hline 25.23 & 2.3 & 97.68 & 0.9 \\
\hline 27.99 & 1.5 & 100.33 & 0.6 \\
\hline 30.47 & 2.6 & 104.97 & 0.8 \\
\hline 32.90 & 1.6 & 107.35 & 1 \\
\hline 35.16 & 1.4 & 109.88 & 1 \\
\hline 40.14 & 0.8 & 112.17 & 0.6 \\
\hline 42.85 & 0.7 & 114.55 & 1 \\
\hline 46.68 & 1.5 & 116.87 & 0.9 \\
\hline 49.10 & 2.0 & 119.19 & 2.1 \\
\hline 51.74 & 2.3 & 121.69 & 1.5 \\
\hline 54.19 & 1.4 & 124.07 & 0.8 \\
\hline 56.82 & 1.7 & 126.41 & 1 \\
\hline 58.73 & 1.9 & 128.74 & 1.4 \\
\hline 61.39 & 0.9 & 131.28 & 2.2 \\
\hline 66.72 & 1.9 & 135.97 & 4.2 \\
\hline 67.27 & 0.7 & 138.36 & 7.3 \\
\hline 68.94 & 1.2 & 140.78 & 20.7 \\
\hline 71.23 & 1.8 & 142.96 & 11.3 \\
\hline 74.14 & 0.7 & 145.53 & 13.5 \\
\hline 76.52 & 1.3 & 147.08 & 1.7 \\
\hline
\end{tabular}


Table B-10

Soil Carbonate Concentrations for U-3at-D1 Characterization Samples (Depth in meters; calcium carbonate equivalent in [oven-dry] weight percent)

\begin{tabular}{|c|c|c|c|}
\hline Location: U-3at-D1 & \multicolumn{3}{|c|}{ Analysis: Soil Carbonate } \\
\hline $\begin{array}{l}\widehat{\text { Eิ }} \\
\text { 言 } \\
\text { D̊ }\end{array}$ & ర్లో & 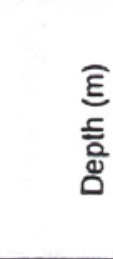 & 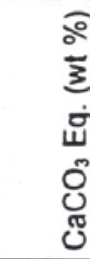 \\
\hline 5.32 & 0.38 & 78.81 & 4.89 \\
\hline 7.65 & 0.33 & 81.10 & 2.10 \\
\hline 10.69 & 1.76 & 83.40 & 6.67 \\
\hline 13.05 & 3.60 & 85.84 & 1.75 \\
\hline 15.15 & 2.50 & 88.28 & 4.12 \\
\hline 17.93 & 4.32 & 90.66 & 6.74 \\
\hline 20.42 & 3.96 & 93.22 & 6.42 \\
\hline 22.94 & 0.47 & 95.48 & 1.11 \\
\hline 25.23 & 2.51 & 97.68 & 4.6 \\
\hline 27.99 & 4.49 & 100.33 & 2.39 \\
\hline 30.47 & 12.06 & 104.97 & 0.84 \\
\hline 32.90 & 0.60 & 107.35 & 2.07 \\
\hline 35.16 & 4.43 & 109.88 & 3.13 \\
\hline 40.14 & 1.08 & 112.17 & 3.31 \\
\hline 42.85 & 1.52 & 114.55 & 4.64 \\
\hline 46.68 & 0.74 & 116.87 & 3.29 \\
\hline 49.10 & 2.61 & 119.19 & 12.55 \\
\hline 51.74 & 7.54 & 121.69 & 2.89 \\
\hline 54.19 & 3.70 & 124.07 & 2.52 \\
\hline 56.82 & 1.10 & 126.41 & 1.57 \\
\hline 58.73 & 1.68 & 128.74 & 4.47 \\
\hline 61.39 & 1.52 & 131.28 & 0.92 \\
\hline 66.72 & 0.83 & 135.97 & 2.53 \\
\hline 67.27 & 4.47 & 138.36 & 1.56 \\
\hline 68.94 & 6.55 & 140.78 & 2.46 \\
\hline 71.23 & 4.42 & 142.96 & 4.65 \\
\hline 74.14 & 1.97 & 145.53 & 2.38 \\
\hline 76.52 & 4.36 & 147.08 & 0.92 \\
\hline
\end{tabular}


Table B-11

Tritium Concentrations for U-3at-D1 Characterization Samples

(Depth in meters; tritium and counting error [1 standard deviation] in picoCuries per liter)

\begin{tabular}{|c|c|c|c|c|c|}
\hline \multicolumn{2}{|c|}{ Location: U-3at-D1 } & Analysis: Tritium & \multirow[b]{2}{*}{ 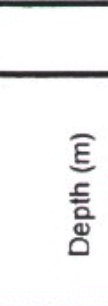 } & \multirow[b]{2}{*}{ 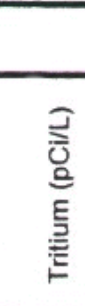 } & \multirow[b]{2}{*}{ 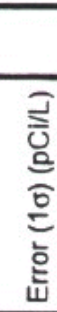 } \\
\hline 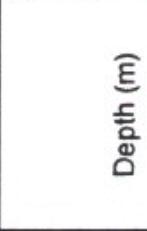 & 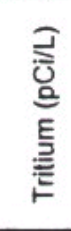 & 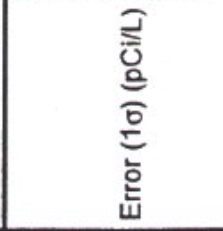 & & & \\
\hline 7.94 & 0 & 283 & 80.92 & 15 & 228 \\
\hline 10.46 & 0 & 275 & 83.25 & 9 & 247 \\
\hline 12.92 & 78 & 274 & 85.69 & 85 & 234 \\
\hline 14.08 & 11 & 300 & 88.13 & 0 & 282 \\
\hline 17.70 & 0 & 312 & 90.51 & 0 & 230 \\
\hline 20.16 & 108 & 290 & 93.07 & 64 & 269 \\
\hline 22.68 & 0 & 282 & 95.21 & 179 & 248 \\
\hline 25.59 & 0 & 228 & 97.95 & 0 & 247 \\
\hline 28.34 & 0 & 255 & 100.00 & 109 & 263 \\
\hline 30.12 & 0 & 305 & 104.82 & 125 & 297 \\
\hline 32.55 & 0 & 250 & 107.20 & 285 & 293 \\
\hline 35.35 & 212 & 251 & 109.64 & 72 & 288 \\
\hline 39.95 & 0 & 304 & 112.02 & 157 & 268 \\
\hline 42.56 & 0 & 294 & 114.40 & 34 & 218 \\
\hline 46.52 & 0 & 255 & 116.72 & 153 & 254 \\
\hline 48.94 & 70 & 300 & 119.04 & 273 & 229 \\
\hline 51.59 & 0 & 246 & 121.54 & 348 & 461 \\
\hline 54.06 & 132 & 279 & 123.92 & 291 & 256 \\
\hline 56.54 & 7 & 235 & 126.26 & 302 & 293 \\
\hline 58.83 & 31 & 259 & 128.59 & 306 & 265 \\
\hline 61.24 & 41 & 257 & 131.10 & 391 & 330 \\
\hline 66.38 & 0 & 226 & 135.82 & 867 & 280 \\
\hline 66.93 & 45 & 268 & 138.21 & 1330 & 299 \\
\hline 68.66 & 0 & 300 & 140.66 & 1710 & 309 \\
\hline 71.45 & 33 & 248 & 142.81 & 1660 & 310 \\
\hline 73.80 & 57 & 261 & 145.38 & 1520 & 314 \\
\hline 76.22 & 25 & 278 & 146.93 & 2200 & 277 \\
\hline 78.60 & 145 & 257 & & & \\
\hline
\end{tabular}


Table B-12

Particle Density for U-3at-D2 Characterization Samples

(Depth in meters; density in kilograms per cubic meter)

\begin{tabular}{|c|c|}
\hline Location: U-3at-D2 & Analysis: Particle Density \\
\hline $\begin{array}{l}\widehat{\underline{E}} \\
\text { 言 } \\
\text { ठ }\end{array}$ & 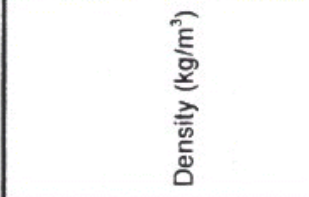 \\
\hline 47.81 & 2360 \\
\hline 50.56 & 2260 \\
\hline 53.19 & 2390 \\
\hline 55.68 & 2520 \\
\hline 58.43 & 2390 \\
\hline 61.05 & 2440 \\
\hline 63.67 & 2370 \\
\hline 66.23 & 2420 \\
\hline 68.72 & 2470 \\
\hline 71.53 & 2410 \\
\hline 74.28 & 2370 \\
\hline 76.64 & 2420 \\
\hline 78.08 & 2430 \\
\hline
\end{tabular}

Table B-13

Particle Size Distribution for Fine-Earth (<2millimeters) Fraction for Characterization Samples

(Depth in meters; particle sizes [weight percent] in millimeters)

\begin{tabular}{|c|c|c|c|c|c|c|c|c|c|c|}
\hline \multicolumn{3}{|c|}{ Location: U-3at-D2 } & \multicolumn{8}{|c|}{ Analysis: Particle Size } \\
\hline & \multicolumn{6}{|c|}{ Sand $(0.05-2 \mathrm{~mm})(w \mathrm{t} \%)$} & \multicolumn{3}{|c|}{ Silt $(2-50 \mathrm{~mm})(\mathrm{wt} \%)$} & \multirow{2}{*}{$\begin{array}{c}\text { Clay }(<2 \mathrm{~mm})(\mathrm{wt} \%) \\
\frac{\pi}{0} \\
\frac{\pi}{\circ}\end{array}$} \\
\hline 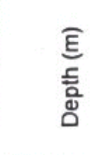 & $\begin{array}{l}E \\
E \\
\stackrel{1}{N} \\
-\end{array}$ & 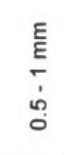 & 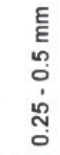 & 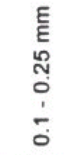 & 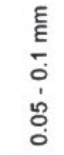 & 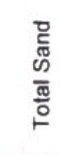 & $\begin{array}{l}E \\
E \\
\text { E } \\
\text { ధ } \\
\text { ○ે }\end{array}$ & $\begin{array}{l}E \\
E \\
\text { D } \\
\dot{\sim}\end{array}$ & $\frac{\overline{\bar{\sigma}}}{\frac{\pi}{\circ}}$ & \\
\hline 42.17 & 15.1 & 15.9 & 22.6 & 25.9 & 9.1 & 88.6 & 0.5 & 4.8 & 5.3 & 6.1 \\
\hline 44.30 & 7.8 & 8.9 & 17.8 & 30.1 & 17.2 & 81.8 & 4.9 & 6.4 & 11.3 & 6.9 \\
\hline 45.88 & 9.4 & 11.8 & 13.9 & 17.9 & 17.3 & 70.4 & 8.3 & 14.6 & 22.9 & 6.7 \\
\hline 47.96 & 10.3 & 15.4 & 26.6 & 21.9 & 8.0 & 82.2 & 0.6 & 4.4 & 5.0 & 12.8 \\
\hline 49.92 & 22.3 & 21.6 & 25.4 & 18.5 & 3.5 & 91.7 & 0.0 & 2.3 & 1.5 & 6.8 \\
\hline 51.79 & 6.8 & 9.8 & 18.4 & 24.0 & 10.7 & 69.7 & 3.1 & 14.2 & 17.3 & 13.0 \\
\hline 53.75 & 6.5 & 8.1 & 16.1 & 30.9 & 18.8 & 80.4 & 3.1 & 7.4 & 10.5 & 9.1 \\
\hline 55.69 & 7.1 & 7.4 & 16.6 & 27.0 & 12.2 & 70.4 & 2.4 & 13.1 & 15.5 & 14.1 \\
\hline 57.68 & 1.0 & 2.3 & 9.5 & 29.8 & 31.2 & 73.8 & 12.5 & 10.1 & 22.6 & 3.6 \\
\hline 59.76 & 5.1 & 6.3 & 15.3 & 30.9 & 14.8 & 72.3 & 1.3 & 14.9 & 16.2 & 11.5 \\
\hline 61.60 & 6.9 & 9.6 & 19.8 & 29.9 & 13.8 & 80.1 & 2.7 & 7.4 & 10.1 & 9.8 \\
\hline 63.52 & 3.4 & 3.4 & 9.3 & 25.1 & 19.6 & 60.8 & 6.6 & 22.4 & 29.0 & 10.2 \\
\hline 65.41 & 29.2 & 33.0 & 18.2 & 4.7 & 1.7 & 87.4 & 0.0 & 1.9 & 0.7 & 11.9 \\
\hline
\end{tabular}


Table B-14

Bulk Density for U-3at-D2 Characterization Samples

(Depth in meters; density in kilograms per cubic meter)

\begin{tabular}{|c|c|c|c|}
\hline \multirow{2}{*}{\begin{tabular}{|c} 
Location: U-3at-D2 \\
\\
Eิ \\
吉 \\
ڤั
\end{tabular}} & \multicolumn{2}{|c|}{ Analysis: Dry Bulk Density } & \multirow[b]{2}{*}{ 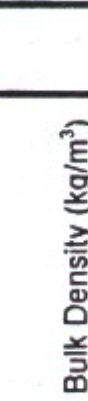 } \\
\hline & 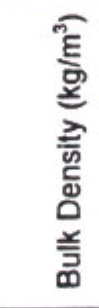 & $\begin{array}{l}\widehat{\underline{\Xi}} \\
\text { 言 } \\
\text { o }\end{array}$ & \\
\hline 47.90 & 1652 & 63.77 & 1544 \\
\hline 48.04 & 1450 & 66.33 & 1283 \\
\hline 50.66 & 1680 & 66.46 & 1510 \\
\hline 50.78 & 1560 & 68.81 & 1522 \\
\hline 50.81 & 1340 & 68.95 & 1620 \\
\hline 53.29 & 1458 & 71.63 & 1354 \\
\hline 53.42 & 1430 & 71.76 & 1420 \\
\hline 55.78 & 1766 & 74.12 & 1410 \\
\hline 55.91 & 1690 & 74.18 & 1335 \\
\hline 58.53 & 1515 & 76.77 & 1560 \\
\hline 58.66 & 1570 & 76.87 & 1636 \\
\hline 61.15 & 1685 & 78.25 & 1835 \\
\hline 61.28 & 1390 & 78.31 & 1410 \\
\hline 63.90 & 1600 & & \\
\hline
\end{tabular}


Table B-15

Water Retention Relations for U-3at-D2 Characterization Samples

(Depth in meters; volumetric water content $[\theta]$ in cubic meters per cubic meter; matric potential [h] MegaPascals)

\begin{tabular}{|c|c|c|c|c|c|c|}
\hline \multicolumn{2}{|c|}{ Location: U-3at-D2 } & \multicolumn{5}{|c|}{ Analysis: Water Retention } \\
\hline Depth (m) & $\begin{array}{c}48.0 \\
\theta\left(\mathrm{m}^{3} \mathrm{~m}^{-3}\right) \\
\end{array}$ & $\mathrm{h}(\mathrm{MPa})$ & $\begin{array}{c}50.8 \\
\theta\left(\mathrm{m}^{3} \mathrm{~m}^{-3}\right) \\
\end{array}$ & $\mathrm{h}(\mathrm{MPa})$ & $\begin{array}{c}50.8 \\
\theta\left(\mathrm{m}^{3} \mathrm{~m}^{-3}\right) \\
\end{array}$ & $\mathrm{h}(\mathrm{MPa})$ \\
\hline 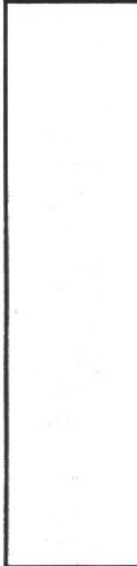 & $\begin{array}{l}0.270 \\
0.196 \\
0.178 \\
0.170 \\
0.163 \\
0.155 \\
0.149 \\
0.145 \\
0.139 \\
0.135 \\
0.130 \\
0.126 \\
0.121 \\
0.115 \\
0.111 \\
0.106 \\
0.101 \\
0.098\end{array}$ & $\begin{array}{l}0.004 \\
0.017 \\
0.030 \\
0.047 \\
0.068 \\
0.106 \\
0.153 \\
0.208 \\
0.295 \\
0.425 \\
0.579 \\
0.756 \\
1.182 \\
1.702 \\
2.316 \\
3.025 \\
3.829 \\
4.727\end{array}$ & $\begin{array}{l}0.251 \\
0.181 \\
0.166 \\
0.158 \\
0.156 \\
0.147 \\
0.141 \\
0.136 \\
0.131 \\
0.127 \\
0.123 \\
0.119 \\
0.115 \\
0.111 \\
0.108 \\
0.105 \\
0.103 \\
0.100\end{array}$ & $\begin{array}{l}0.004 \\
0.017 \\
0.030 \\
0.047 \\
0.068 \\
0.106 \\
0.153 \\
0.208 \\
0.295 \\
0.425 \\
0.579 \\
0.756 \\
1.182 \\
1.702 \\
2.316 \\
3.025 \\
3.829 \\
4.727\end{array}$ & $\begin{array}{l}0.462 \\
0.418 \\
0.398 \\
0.381 \\
0.362 \\
0.340 \\
0.320 \\
0.304 \\
0.285 \\
0.265 \\
0.251 \\
0.238 \\
0.218 \\
0.205 \\
0.195 \\
0.187 \\
0.179 \\
0.172 \\
\end{array}$ & $\begin{array}{l}0.004 \\
0.017 \\
0.030 \\
0.047 \\
0.068 \\
0.106 \\
0.153 \\
0.208 \\
0.295 \\
0.425 \\
0.579 \\
0.756 \\
1.182 \\
1.702 \\
2.316 \\
3.025 \\
3.829 \\
4.727 \\
\end{array}$ \\
\hline
\end{tabular}

\begin{tabular}{|c|c|c|c|c|c|c|}
\hline \multicolumn{2}{|c|}{ Location: U-3at-D2 } & \multicolumn{5}{|c|}{ Analysis: Water Retention } \\
\hline Depth $(m)$ & $\begin{array}{c}53.4 \\
\theta\left(m^{3} m^{-3}\right) \\
\end{array}$ & $\mathrm{h}(\mathrm{MPa})$ & $\begin{array}{c}55.9 \\
\theta\left(\mathrm{m}^{3} \mathrm{~m}^{-3}\right) \\
\end{array}$ & $\mathrm{h}(\mathrm{MPa})$ & $\begin{array}{c}58.7 \\
\theta\left(\mathrm{m}^{3} \mathrm{~m}^{-3}\right) \\
\end{array}$ & $\mathrm{h}(\mathrm{MPa})$ \\
\hline & $\begin{array}{l}0.439 \\
0.318 \\
0.276 \\
0.254 \\
0.241 \\
0.228 \\
0.218 \\
0.210 \\
0.202 \\
0.194 \\
0.188 \\
0.182 \\
0.171 \\
0.163 \\
0.155 \\
0.149 \\
0.142 \\
0.137 \\
\end{array}$ & $\begin{array}{l}0.004 \\
0.017 \\
0.030 \\
0.047 \\
0.068 \\
0.106 \\
0.153 \\
0.208 \\
0.295 \\
0.425 \\
0.579 \\
0.756 \\
1.182 \\
1.702 \\
2.316 \\
3.025 \\
3.829 \\
4.727\end{array}$ & $\begin{array}{l}0.212 \\
0.148 \\
0.136 \\
0.129 \\
0.126 \\
0.121 \\
0.117 \\
0.114 \\
0.111 \\
0.108 \\
0.105 \\
0.102 \\
0.099 \\
0.096 \\
0.094 \\
0.091 \\
0.089 \\
0.087 \\
\end{array}$ & $\begin{array}{l}0.004 \\
0.017 \\
0.030 \\
0.047 \\
0.068 \\
0.106 \\
0.153 \\
0.208 \\
0.295 \\
0.425 \\
0.579 \\
0.756 \\
1.182 \\
1.702 \\
2.316 \\
3.025 \\
3.829 \\
4.727 \\
\end{array}$ & $\begin{array}{l}0.402 \\
0.327 \\
0.284 \\
0.262 \\
0.244 \\
0.227 \\
0.215 \\
0.206 \\
0.196 \\
0.186 \\
0.177 \\
0.170 \\
0.159 \\
0.150 \\
0.143 \\
0.137 \\
0.131 \\
0.127 \\
\end{array}$ & $\begin{array}{l}0.004 \\
0.017 \\
0.030 \\
0.047 \\
0.068 \\
0.106 \\
0.153 \\
0.208 \\
0.295 \\
0.425 \\
0.579 \\
0.756 \\
1.182 \\
1.702 \\
2.316 \\
3.025 \\
3.829 \\
4.727\end{array}$ \\
\hline
\end{tabular}


Table B-15

Water Retention Relations for U-3at-D2 Characterization Samples (continued)

(Depth in meters; volumetric water content $[\theta]$ in cubic meters per cubic meter; matric potential [h] MegaPascals)

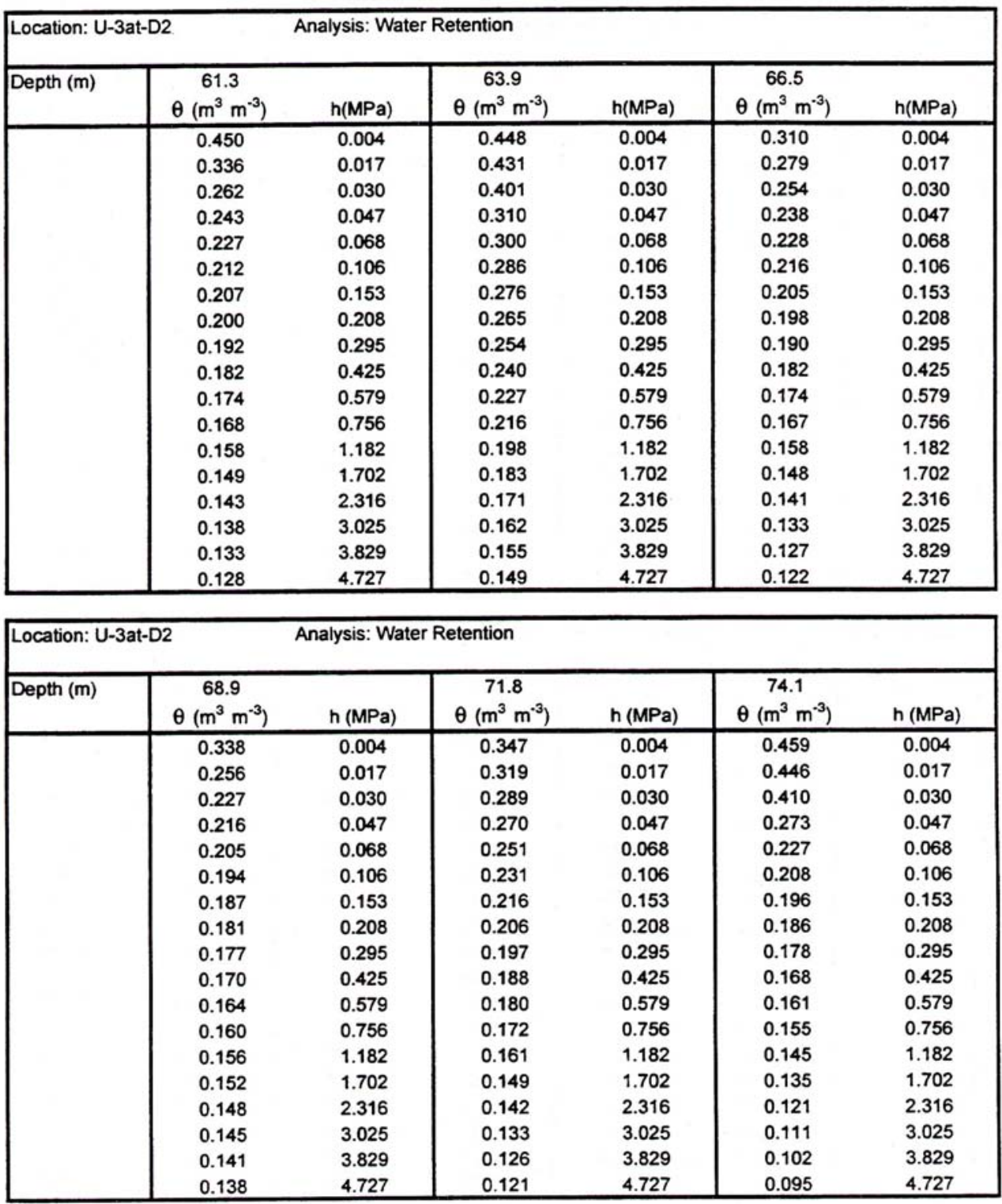


Table B-15

Water Retention Relations for U-3at-D2 Characterization Samples (continued) (Depth in meters; volumetric water content $[\theta]$ in cubic meters per cubic meter; matric potential [h] MegaPascals)

\begin{tabular}{|c|c|c|c|c|c|}
\hline \multicolumn{2}{|c|}{ Location: U-3at-D2 } & \multicolumn{3}{|c|}{ Analysis: Water Retention } & \\
\hline Depth $(m)$ & $\begin{array}{c}76.8 \\
\theta\left(\mathrm{m}^{3} \mathrm{~m}^{-3}\right)\end{array}$ & $\mathrm{h}(\mathrm{MPa})$ & $\begin{array}{c}78.3 \\
\theta\left(\mathrm{m}^{3} \mathrm{~m}^{-3}\right)\end{array}$ & $h(\mathrm{MPa})$ & \\
\hline & $\begin{array}{l}0.316 \\
0.211 \\
0.192 \\
0.180 \\
0.172 \\
0.164 \\
0.158 \\
0.153 \\
0.150 \\
0.143 \\
0.139 \\
0.135 \\
0.130 \\
0.126 \\
0.121 \\
0.117 \\
0.114 \\
0.110\end{array}$ & $\begin{array}{l}0.004 \\
0.017 \\
0.030 \\
0.047 \\
0.068 \\
0.106 \\
0.153 \\
0.208 \\
0.295 \\
0.425 \\
0.579 \\
0.756 \\
1.182 \\
1.702 \\
2.316 \\
3.025 \\
3.829 \\
4.727\end{array}$ & $\begin{array}{l}0.404 \\
0.386 \\
0.353 \\
0.308 \\
0.271 \\
0.255 \\
0.243 \\
0.233 \\
0.224 \\
0.215 \\
0.209 \\
0.202 \\
0.191 \\
0.182 \\
0.174 \\
0.166 \\
0.160 \\
0.154\end{array}$ & $\begin{array}{l}0.004 \\
0.017 \\
0.030 \\
0.047 \\
0.068 \\
0.106 \\
0.153 \\
0.208 \\
0.295 \\
0.425 \\
0.579 \\
0.756 \\
1.182 \\
1.702 \\
2.316 \\
3.025 \\
3.829 \\
4.727\end{array}$ & \\
\hline
\end{tabular}


Table B-16

Hydraulic Conductivity I Water Content Relations for U-3at-D2 Characterization Samples

(Depth in meters; volumetric water content $[\theta]$ in cubic meters per cubic meter; hydraulic conductivity $[\mathrm{K}]$ in meters per second)

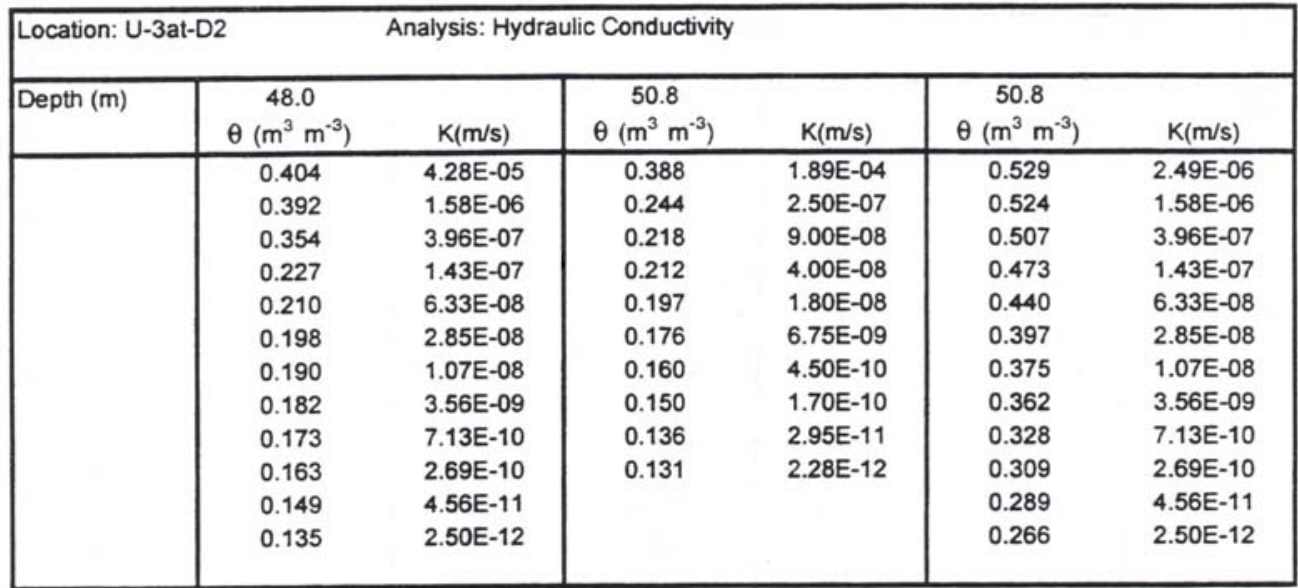

\begin{tabular}{|c|c|c|c|c|c|c|}
\hline \multicolumn{2}{|c|}{ Location: U-3at-D2 } & \multicolumn{5}{|c|}{ Analysis: Hydraulic Conductivity } \\
\hline Depth (m) & $\begin{array}{c}53.4 \\
\theta\left(\mathrm{m}^{3} \mathrm{~m}^{-3}\right) \\
\end{array}$ & $\mathrm{K}(\mathrm{m} / \mathrm{s})$ & $\begin{array}{c}55.9 \\
\theta\left(\mathrm{m}^{3} \mathrm{~m}^{-3}\right) \\
\end{array}$ & $\mathrm{K}(\mathrm{m} / \mathrm{s})$ & $\begin{array}{c}58.7 \\
\theta\left(\mathrm{m}^{3} \mathrm{~m}^{-3}\right) \\
\end{array}$ & $\mathrm{K}(\mathrm{m} / \mathrm{s})$ \\
\hline & $\begin{array}{l}0.491 \\
0.454 \\
0.404 \\
0.350 \\
0.314 \\
0.285 \\
0.275 \\
0.264 \\
0.247 \\
0.233 \\
0.213 \\
0.196\end{array}$ & $\begin{array}{l}3.04 \mathrm{E}-06 \\
1.58 \mathrm{E}-06 \\
3.96 \mathrm{E}-07 \\
1.43 \mathrm{E}-07 \\
6.33 \mathrm{E}-08 \\
2.85 \mathrm{E}-08 \\
1.07 \mathrm{E}-08 \\
3.56 \mathrm{E}-09 \\
7.13 \mathrm{E}-10 \\
2.69 \mathrm{E}-10 \\
4.56 \mathrm{E}-11 \\
2.50 \mathrm{E}-12\end{array}$ & $\begin{array}{l}0.320 \\
0.221 \\
0.191 \\
0.169 \\
0.161 \\
0.148 \\
0.134 \\
0.127 \\
0.120 \\
0.113\end{array}$ & $\begin{array}{l}3.84 E-05 \\
2.50 E-07 \\
9.00 E-08 \\
4.00 E-08 \\
1.80 E-08 \\
6.75 E-09 \\
4.50 E-10 \\
1.70 E-10 \\
2.95 E-11 \\
2.28 E-12\end{array}$ & $\begin{array}{l}0.385 \\
0.503 \\
0.445 \\
0.335 \\
0.308 \\
0.281 \\
0.264 \\
0.250 \\
0.233 \\
0.221 \\
0.203 \\
0.198\end{array}$ & $\begin{array}{l}4.80 E-07 \\
7.37 E-06 \\
1.58 E-06 \\
1.43 E-07 \\
6.33 E-08 \\
2.85 E-08 \\
1.07 E-08 \\
3.56 E-09 \\
7.13 E-10 \\
3.23 E-10 \\
5.30 E-11 \\
4.26 E-12\end{array}$ \\
\hline
\end{tabular}

\begin{tabular}{|c|c|c|c|c|c|c|}
\hline \multicolumn{2}{|c|}{ Location: U-3at-D2 } & \multicolumn{5}{|c|}{ Analysis: Hydraulic Conductivity } \\
\hline Depth $(m)$ & $\begin{array}{c}61.3 \\
\theta\left(\mathrm{m}^{3} \mathrm{~m}^{-3}\right) \\
\end{array}$ & $\mathrm{K}(\mathrm{m} / \mathrm{s})$ & $\begin{array}{c}63.9 \\
\theta\left(\mathrm{m}^{3} \mathrm{~m}^{-3}\right) \\
\end{array}$ & $\mathrm{K}(\mathrm{m} / \mathrm{s})$ & $\begin{array}{c}66.5 \\
\theta\left(\mathrm{m}^{3} \mathrm{~m}^{-3}\right) \\
\end{array}$ & $\mathrm{K}(\mathrm{m} / \mathrm{s})$ \\
\hline & $\begin{array}{l}0.440 \\
0.425 \\
0.396 \\
0.322 \\
0.300 \\
0.275 \\
0.262 \\
0.238 \\
0.228 \\
0.219 \\
0.198 \\
0.192\end{array}$ & $\begin{array}{l}5.94 E-06 \\
1.58 E-06 \\
3.96 E-07 \\
1.43 E-07 \\
6.33 E-08 \\
2.85 E-08 \\
1.07 E-08 \\
3.56 E-09 \\
7.13 E-10 \\
3.23 E-10 \\
5.30 E-11 \\
4.26 E-12\end{array}$ & $\begin{array}{l}0.399 \\
0.380 \\
0.360 \\
0.329 \\
0.313 \\
0.300 \\
0.279 \\
0.265 \\
0.254 \\
0.252\end{array}$ & $\begin{array}{l}1.94 E-07 \\
1.43 E-07 \\
6.33 E-08 \\
2.85 E-08 \\
1.07 E-08 \\
3.56 E-09 \\
7.13 E-10 \\
2.69 E-10 \\
4.60 E-11 \\
3.81 E-12\end{array}$ & $\begin{array}{l}0.404 \\
0.360 \\
0.319 \\
0.285 \\
0.256 \\
0.253 \\
0.243 \\
0.221 \\
0.207 \\
0.192 \\
0.189\end{array}$ & $\begin{array}{l}8.41 E-07 \\
3.96 E-07 \\
1.43 E-07 \\
6.33 E-08 \\
2.85 E-08 \\
1.07 E-08 \\
3.56 E-09 \\
7.13 E-10 \\
2.69 E-10 \\
4.56 E-11 \\
3.60 E-12\end{array}$ \\
\hline
\end{tabular}


Table B-16

Hydraulic Conductivity-Water Content Relations for U-3at-D2 Characterization Samples (continued)

(Depth in meters; volumetric water content $[\theta]$ in cubic meters per cubic meter; hydraulic conductivity $[\mathrm{K}]$ in meters per second)

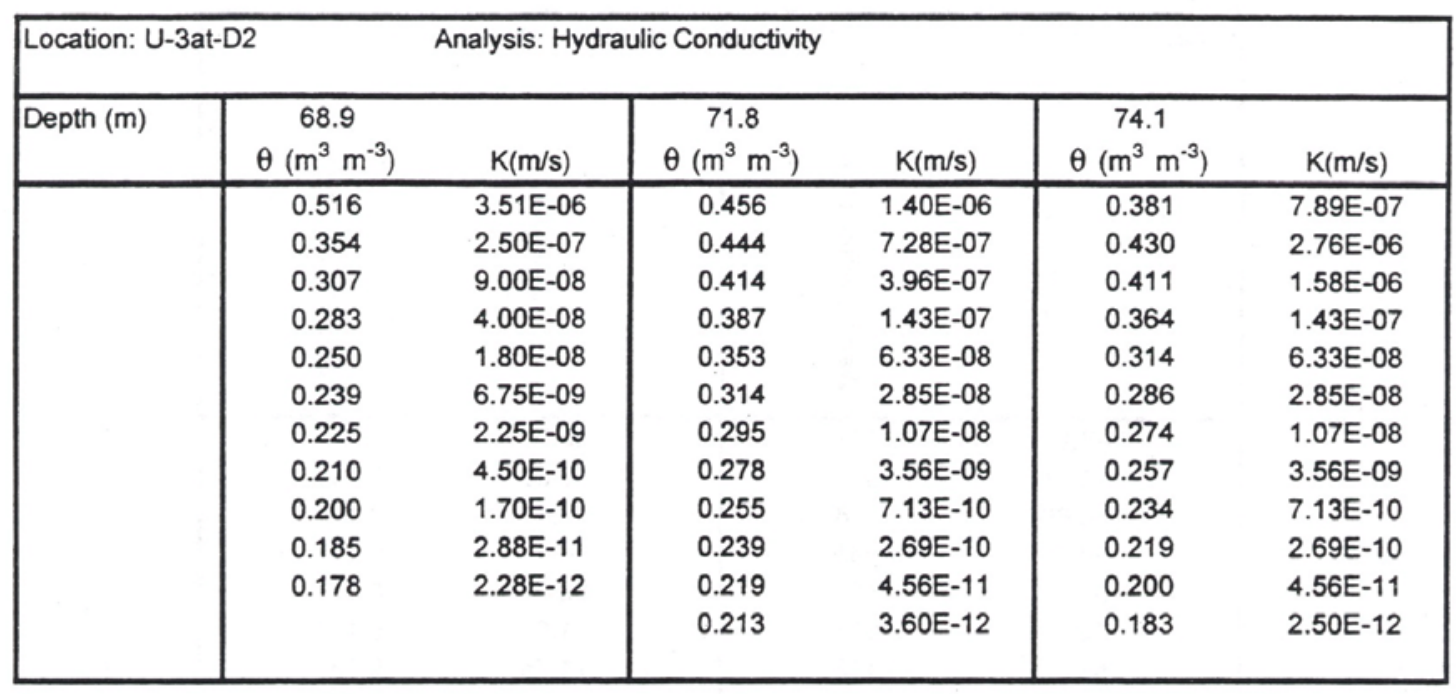

\begin{tabular}{|c|c|c|c|c|c|}
\hline \multicolumn{2}{|c|}{ Location: U-3at-D2 } & \multicolumn{3}{|c|}{ Analysis: Hydraulic Conductivity } & \\
\hline Depth $(\mathrm{m})$ & $\begin{array}{c}76.8 \\
\theta\left(\mathrm{m}^{3} \mathrm{~m}^{-3}\right)\end{array}$ & $\mathrm{K}(\mathrm{m} / \mathrm{s})$ & $\begin{array}{c}78.3 \\
\theta\left(\mathrm{m}^{3} \mathrm{~m}^{-3}\right)\end{array}$ & $\mathrm{K}(\mathrm{m} / \mathrm{s})$ & \\
\hline & $\begin{array}{l}0.374 \\
0.266 \\
0.240 \\
0.213 \\
0.208 \\
0.196 \\
0.182 \\
0.172 \\
0.158 \\
0.104\end{array}$ & $\begin{array}{l}2.50 \mathrm{E}-07 \\
9.00 \mathrm{E}-08 \\
4.00 \mathrm{E}-08 \\
1.80 \mathrm{E}-08 \\
6.75 \mathrm{E}-09 \\
2.25 \mathrm{E}-09 \\
4.50 \mathrm{E}-10 \\
1.70 \mathrm{E}-10 \\
2.88 \mathrm{E}-11 \\
2.28 \mathrm{E}-12\end{array}$ & $\begin{array}{l}0.468 \\
0.442 \\
0.408 \\
0.356 \\
0.333 \\
0.312 \\
0.294 \\
0.284 \\
0.263 \\
0.249 \\
0.232 \\
0.216\end{array}$ & $\begin{array}{l}3.77 E-06 \\
1.58 E-06 \\
3.96 E-07 \\
1.43 E-07 \\
6.33 E-08 \\
2.85 E-08 \\
1.07 E-08 \\
3.56 E-09 \\
7.13 E-10 \\
2.69 E-10 \\
4.56 E-11 \\
2.50 E-12\end{array}$ & \\
\hline
\end{tabular}


Table B-17

Volumetric Water Content for U-3at-D2 Characterization Samples

(Depth in meters; water content in cubic meters per cubic meter)

\begin{tabular}{|c|c|c|c|}
\hline \multirow{2}{*}{ 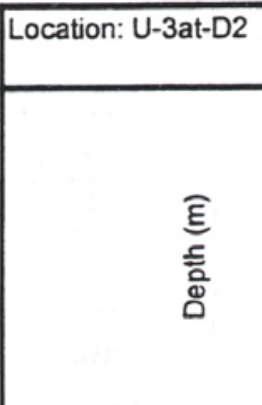 } & \multicolumn{3}{|c|}{ Analysis: Volumetric Water Content } \\
\hline & 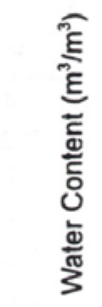 & 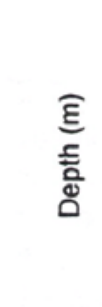 & 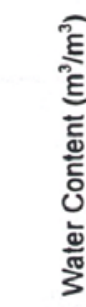 \\
\hline 47.90 & 0.121 & 63.77 & 0.145 \\
\hline 48.04 & 0.067 & 66.33 & 0.148 \\
\hline 50.66 & 0.118 & 66.46 & 0.156 \\
\hline 50.78 & 0.091 & 68.81 & 0.147 \\
\hline 50.81 & 0.189 & 68.95 & 0.117 \\
\hline 53.29 & 0.176 & 71.63 & 0.187 \\
\hline 53.42 & 0.153 & 71.76 & 0.151 \\
\hline 55.78 & 0.117 & 74.12 & 0.140 \\
\hline 55.91 & 0.078 & 74.18 & 0.149 \\
\hline 58.53 & 0.145 & 76.77 & 0.106 \\
\hline 58.66 & 0.142 & 76.87 & 0.180 \\
\hline 61.15 & 0.171 & 78.25 & 0.254 \\
\hline 61.28 & 0.162 & 78.31 & 0.174 \\
\hline 63.90 & 0.144 & & \\
\hline
\end{tabular}

Table B-18

Water Potential for U-3at-D2 Characterization Samples

(Depth in meters; water potential in MegaPascals)

\begin{tabular}{|c|c|c|c|}
\hline Location: U-3at-D2 & Analysis: Water Potential & & \\
\hline 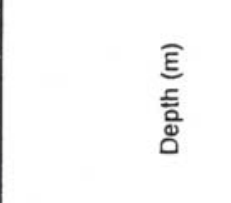 & 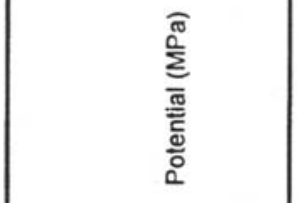 & $\begin{array}{l}\widehat{\Xi} \\
\text { 咅 } \\
\text { ه }\end{array}$ & 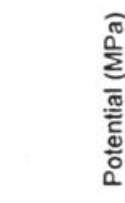 \\
\hline 47.90 & -2.163 & 66.33 & -0.595 \\
\hline 50.66 & -0.687 & 68.81 & $>-0.400$ \\
\hline 53.29 & -0.412 & 71.63 & $>-0.400$ \\
\hline 55.78 & -1.239 & 74.18 & $>-0.400$ \\
\hline 58.53 & -0.595 & 76.87 & $>-0.400$ \\
\hline 61.15 & $>-0.400$ & 78.25 & $>-0.400$ \\
\hline 63.77 & -0.549 & & \\
\hline
\end{tabular}


Table B-19

Stable Isotope Concentrations for U-3at-D2 Characterization Samples

(Depth in meters; oxygen-18 $\left[{ }^{18} \mathrm{O}\right]$ and deuterium [D] concentrations expressed in standard delta notation relative to standard mean ocean water in parts per thousand)

\begin{tabular}{|c|c|c|}
\hline Location: U-3at-D2 & & Isotopes \\
\hline $\begin{array}{l}\widehat{\underline{E}} \\
\text { 言 } \\
\text { Dे }\end{array}$ & $\begin{array}{l}\frac{8}{2} \\
0 \\
\frac{\infty}{\infty}\end{array}$ & $\frac{\overline{8}}{2}$ \\
\hline 47.71 & -13.0 & -101 \\
\hline 50.46 & -14.2 & -107 \\
\hline 53.10 & -14.5 & -106 \\
\hline 55.59 & -14.3 & -108 \\
\hline 58.34 & -14.2 & -108 \\
\hline 60.96 & -14.3 & -108 \\
\hline 63.58 & -14.6 & -109 \\
\hline 66.13 & -14.3 & -112 \\
\hline 68.49 & -13.5 & -104 \\
\hline 71.43 & -15.0 & -111 \\
\hline 74.38 & -14.2 & -107 \\
\hline 76.94 & -14.5 & -111 \\
\hline 78.18 & -14.4 & -108 \\
\hline
\end{tabular}

Table B-20

Soil Chloride Concentrations for U-3at-D2 Characterizations Samples (Depth in meters; chloride in milligrams per kilogram)

\begin{tabular}{|c|c|c|c|}
\hline Location: U-3at-D2 & Analysis: Soil Ch & & \\
\hline $\begin{array}{l}\widehat{\bar{E}} \\
\text { 言 } \\
\text { o }\end{array}$ & 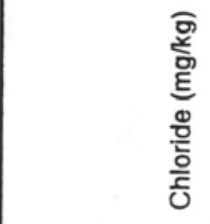 & 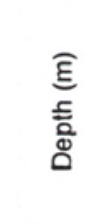 & $\begin{array}{l}\text { बू } \\
\text { क् } \\
\text { 응 }\end{array}$ \\
\hline 47.81 & 3.2 & 66.23 & 1.4 \\
\hline 50.56 & 1.7 & 68.72 & 1.2 \\
\hline 53.19 & 1.4 & 71.53 & 1.1 \\
\hline 55.68 & 1.0 & 74.28 & 0.7 \\
\hline 58.43 & 0.8 & 76.64 & 0.5 \\
\hline 61.05 & 0.7 & 78.08 & 1.2 \\
\hline 63.67 & 1.0 & & \\
\hline
\end{tabular}


Table B-21

Soil Carbonate Concentrations for U-3at-D2 Characterization Samples

(Depth in meters; calcium carbonate equivalent in [oven-dry] weight percent)

\begin{tabular}{|c|c|c|c|}
\hline Location: U-3at-D2 & Analysis: Soil Carbonate & & \\
\hline $\begin{array}{l}\widehat{\underline{E}} \\
\text { 言 } \\
\text { ه }\end{array}$ & 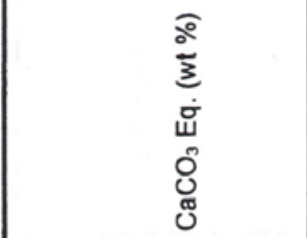 & $\begin{array}{l}\bar{\xi} \\
\text { 产 } \\
\text { Dे }\end{array}$ & 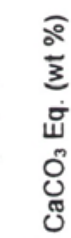 \\
\hline 47.81 & 2.95 & 66.23 & 2.87 \\
\hline 50.56 & 1.76 & 68.72 & 7.76 \\
\hline 53.19 & 7.52 & 71.53 & 9.18 \\
\hline 55.68 & 3.40 & 74.28 & 3.94 \\
\hline 58.43 & 1.99 & 76.64 & 4.52 \\
\hline 61.05 & 2.63 & 78.08 & 1.86 \\
\hline 63.67 & 6.21 & & \\
\hline
\end{tabular}

Table B-22

Tritium Concentration for U-3at-D2 Characterization Samples

(Depth in meters; tritium and counting error [1 standard deviation] in picoCuries per liter)

\begin{tabular}{|c|c|c|c|c|c|}
\hline Location: U-3at-D2 & & s: Triti & & & \\
\hline $\begin{array}{l}\widehat{\underline{\Xi}} \\
\overline{\overline{0}} \\
\bar{\Delta}\end{array}$ & 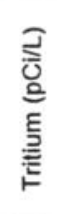 & 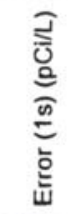 & $\begin{array}{l}\widehat{\Xi} \\
\text { 言 } \\
\text { هั }\end{array}$ & 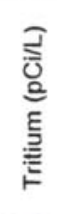 & 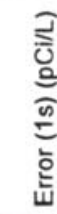 \\
\hline 47.64 & 47 & 270 & 66.06 & 34 & 286 \\
\hline 50.40 & 25 & 299 & 68.42 & 99 & 286 \\
\hline 53.03 & 27 & 289 & 71.37 & 0 & 260 \\
\hline 55.52 & 89 & 275 & 73.99 & 0 & 335 \\
\hline 58.27 & 0 & 307 & 77.00 & 20 & 281 \\
\hline 60.89 & 0 & 325 & 77.98 & 0 & 337 \\
\hline 63.51 & 0 & 339 & & & \\
\hline
\end{tabular}

